(4 norden

\title{
End-of-Waste Criteria for Construction \& Demolition Waste
}







\section{End-of-Waste Criteria for Construction \& Demolition Waste}

Ole Hjelmar, Jette Bjerre Hansen, Margareta Wahlström and Ola Wik 
End-of-Waste Criteria for Construction \& Demolition Waste

Ole Hjelmar, Jette Bjerre Hansen, Margareta Wahlström and Ola Wik

ISBN 978-92-893-4561-3 (PRINT)

ISBN 978-92-893-4562-0 (PDF)

ISBN 978-92-893-4563-7 (EPUB)

http://dx.doi.org/10.6027/TN2016-524

TemaNord 2016:524

ISSN 0908-6692

(C) Nordic Council of Ministers 2016

Layout: Hanne Lebech

Cover photo: Ole Hjelmar, Danish Waste Solutions ApS

Print: Rosendahls-Schultz Grafisk

Printed in Denmark

This publication has been published with financial support by the Nordic Council of Ministers. However, the contents of this publication do not necessarily reflect the views, policies or recommendations of the Nordic Council of Ministers.

www.norden.org/nordpub

\section{Nordic co-operation}

Nordic co-operation is one of the world's most extensive forms of regional collaboration, involving Denmark, Finland, Iceland, Norway, Sweden, and the Faroe Islands, Greenland, and Åland.

Nordic co-operation has firm traditions in politics, the economy, and culture. It plays an important role in European and international collaboration, and aims at creating a strong Nordic community in a strong Europe.

Nordic co-operation seeks to safeguard Nordic and regional interests and principles in the global community. Common Nordic values help the region solidify its position as one of the world's most innovative and competitive.

\section{Nordic Council of Ministers}

Ved Stranden 18

DK-1061 Copenhagen K

Phone (+45) 33960200

\section{www.norden.org}




\section{Contents}

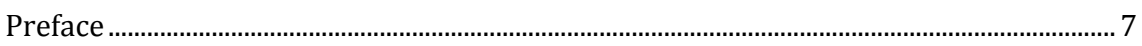

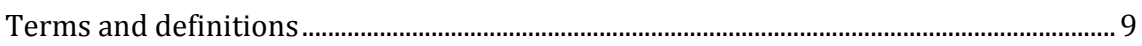

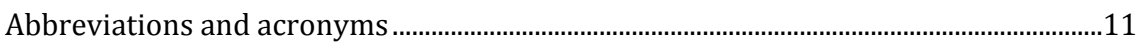

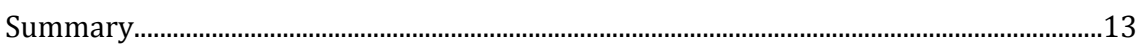

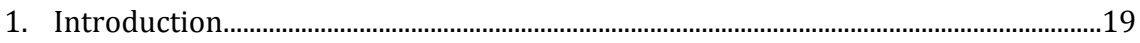

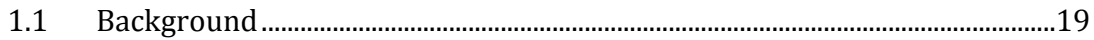

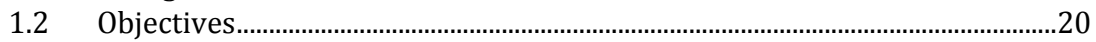

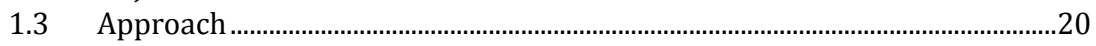

2. Legislation related to EoW for C\&D waste ................................................................23

2.1 The requirements laid down in Article 6 of the Waste Framework

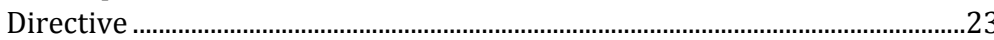

2.2 The requirements laid down in Article 5 of the WFD (on by-

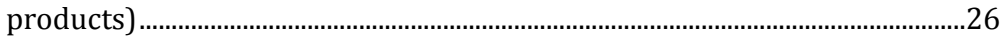

2.3 The transition from waste legislation to product legislation...........................27

2.4 The Construction Products Directive/Regulation ..............................................28

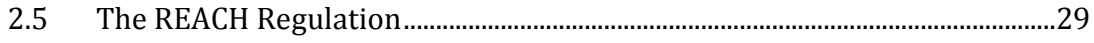

2.6 Other EU directives that may influence EoW conditions for

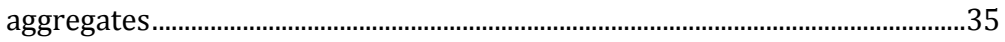

3. EoW for aggregates in the Nordic countries: Status and policy....................................

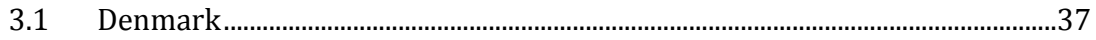

$3.2 \quad$ Faroe Islands ........................................................................................................

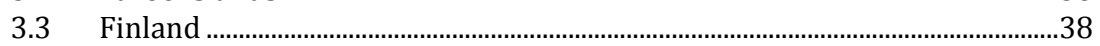

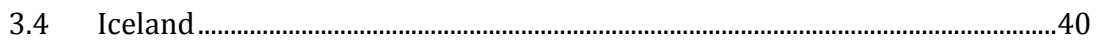

$3.5 \quad$ Norway..................................................................................................................... 40

3.6 Sweden....................................................................................................................... 41

4. Status of the use of C\&D waste and other aggregates in the Nordic countries............43

4.1 Amounts, recycling and regulation of C\&D waste and other

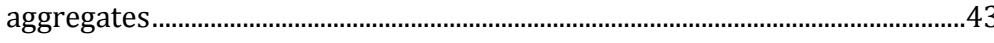

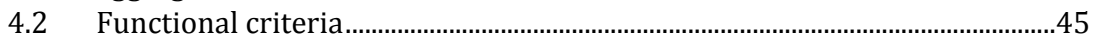

4.3 Relevant studies and data regarding environmental and health related properties of C\&D waste..........................................................................46

4.4 Substances of environmental and health concern............................................49

5. Methodology for development of EoW criteria for C\&D waste in the Nordic countries with particular focus on leaching ..................................................51

5.1 Potential impacts on the environment and human health resulting from use of C\&D waste with EoW status ...........................................................51

5.2 Use without or with restrictions/conditions ...................................................61

5.3 EoW criteria without restrictions or conditions on the use ............................65

5.4 Conditions that can modify EoW leaching limit values ....................................68

5.5 EoW leaching criteria with restrictions/conditions on the use ......................71

5.6 Testing and documentation requirements ....................................................79

5.7 Selected examples of scenario calculations.......................................................81

5.8 Requirements on input materials and pre-treatment of C\&D waste.............86 


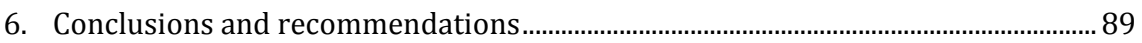

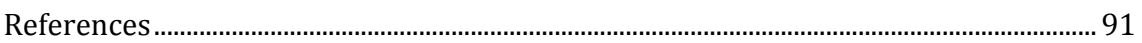

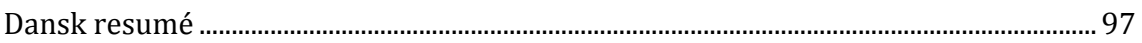

Appendix 1: Management of C\&D waste in Denmark ......................................................103

Management of C\&D waste as aggregates in Denmark ..............................................103

Appendix 2: Management of C\&D waste in the Faroe Islands........................................119

Management of C\&D waste in the Faroe Islands ......................................................119

Appendix 3: Management of C\&D waste in Finland ........................................................121

Utilisation of C\&D waste as aggregates in Finland ....................................................121

Appendix 4: Management of C\&D waste in Norway.........................................................133

Recycling of C\&D waste in Norway ..........................................................................133

Appendix 5: Management of C\&D waste in Sweden ........................................................141

Recycling of C\&D waste in Sweden …….............................................................141

Appendix 6: Leaching as a function of L/S and pH......................................................159

Leaching as a function of $\mathrm{L} / \mathrm{S}$ and $\mathrm{pH}$.....................................................................159

Appendix 7: Description of leaching tests .....................................................................167

Leaching protocols ..........................................................................................................167

Appendix 8: Description of the methodology used to set EU WAC for landfilling ......... 173

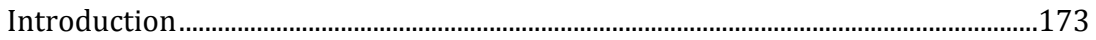

Overall approach and methodology........................................................................174

Selection of targets for protection and contaminants to be included .....................176

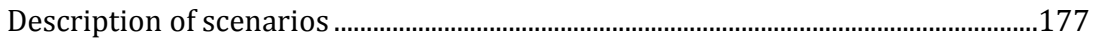

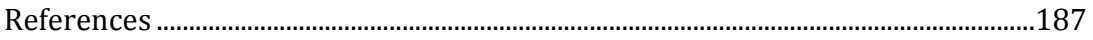




\section{Preface}

This document is the final report on the project "End-of-Waste Criteria for Construction \& Demolition Waste" which was financed by the Nordic Council of Ministers and DHI. The project was initiated in 2010 and finalised in 2012.

The project work has been followed by a Steering Group consisting of the Nordic EoW Group under the Nordic Waste Group:

Denmark: Lene Gravesen, Miljøstyrelsen (Chairwoman).

Norway: Jon Fonnlid Larsen, Klima- og Forurensningsdirektoratet.

Sweden: Carl Mikael Strauss/Erika Nygren, Naturvårdsverket.

Isabelle Thélin, Klima- og Forurensningsdirektoratet, Norway, (until January 2011) and Metta Wiese, The Representation of Greenland, (from 2011) have been project managers from the Nordic Council of Ministers.

The project was carried out by DHI in Denmark in cooperation with VTT in Finland and SGI in Sweden. The project group consisted of the following persons:

Ole Hjelmar

DHI, Denmark (project manager and main author).

Jette Bjerre Hansen

DHI, Denmark.

Margareta Wahlström

VTT, Finland.

Ola Wik

SGI, Sweden. 



\section{Terms and definitions}

Aggregate

Article

Impurity

Preparation

Recovery
Granular material used in construction. Aggregates may be natural, manufactured or recycled (EN 13242). A natural (primary) aggregate originates from mineral sources which have been subjected to nothing more than mechanical processing. A manufactured (secondary) aggregate is an aggregate of mineral origin resulting from an industrial process involving thermal or other modification. A recycled aggregate is an aggregate resulting from the processing of inorganic material previously used in construction.

Means an object which during production is given a special shape, surface or design which determines its function to a greater degree that does its chemical composition (REACH, Title I, Chapter 2, Article 3 (3)).

Means an unintended constituent present in a substance as produced. It may originate from the starting materials or be the result of secondary or incomplete reactions during the reaction process. While it is present in the final substance it was not intentionally added (ECHA Guidance for identification and naming of substances under REACH).

Means a mixture or solution composed of two or more substances (REACH, Title I, Chapter 2, Article 3 (2)).

Any operation the principal result of which is waste serving a useful purpose by replacing other materials which would otherwise have been used to fulfil a particular function, or waste being prepared to fulfil that function, in the plant or in the wider economy. Annex II [to the WFD] sets out a non-exhaustive list of recovery operations (WFD Article 3 (15)). Annex II to the WFD includes "recycling of inorganic construction materials". 
Recycling Any recovery operation by which waste materials are reprocessed into products, materials or substances whether for the original or other purposes. It includes the reprocessing of organic material but does not include energy recovery and the reprocessing into materials that are to be used as fuels or for backfilling operations (WFD Article 3 (17)).

Re-use Any operation by which products or components that are not waste are used again for the same purpose for which they were conceived (WFD Article 3 (13)).

Substance Means a chemical element and its compounds in the natural state or obtained by any manufacturing process, including any additive necessary to preserve its stability and any impurity deriving from the process used, but excluding any solvent which may be separated without affecting the stability of the substance or changing its composition (REACH, Title I, Chapter 2, Article 3 (1)).

Use Means any processing, formulation, consumption, storage, keeping, treatment, filling into containers, transfer from on container to another, mixing, production of an article or any other utilisation (REACH, Title I, Chapter 2, Article 3 (24)).

Waste Means any substance or object which the holder discards or intends or is required to discard (WFD, Article 3 (1)). 


\title{
Abbreviations and acronyms
}

\author{
BTEX Benzene, toluene, ethylbenzene and xylene(s). \\ C\&D Construction and Demolition. \\ CPD Construction Products Directive (89/106/EEC). \\ CPR Construction Products Regulation (Regulation (EU) No. \\ 305/2011 of the European Parliament and of the Council \\ of 9 March 2011 laying down harmonized conditions for \\ the marketing of construction products and repealing \\ Council Directive 89/106/EEC). \\ DOC Dissolved organic carbon. \\ DWQC Drinking water quality criteria. \\ EC European Commission. \\ ECHA European Chemicals Agency. \\ EoL End-of-Life. \\ EoW End-of-Waste. \\ ER3 Essential Requirement 3: "Health, hygiene and the environ- \\ ment" (in Construction Products Directive). \\ EWC European Waste Catalogue. \\ FPC Factory production control. \\ ITT Initial type testing. \\ JRC IPTS Joint Research Centre, Institute for Prospective Technol- \\ ogy Studies (part of the EU Commission). \\ L/S Liquid/Solid ratio. \\ MST Miljøstyrelsen (Danish Environmental Protection Agency). \\ MSW Municipal solid waste. \\ PAH Polycyclic aromatic hydrocarbons. \\ PCB Polychlorinated biphenyls. \\ POC Point of compliance.
}


REACH The European Community Regulation on chemicals and their safe use (EC 1907/2006). ${ }^{1}$ It deals with the Registration, Evaluation, Authorisation and Restriction of Chemical substances.

SVHC Substances of Very High Concern.

UVCB Substance of Unknown or Variable composition, Complex reaction products or Biological materials.

WAC Waste Acceptance Criteria.

WFD Waste Framework Directive (2008/98/EC).

WHO World Health Organisation.

WQC Water quality criteria. 


\section{Summary}

The Waste Framework Directive (WFD) 2008/98/EC includes the option to set so-called End-of-Waste (EoW) criteria under which specified waste fractions shall cease to be waste. If these criteria are fulfilled, the material will no longer be classified as a waste but it will instead become a product subject to free trade and use (albeit for specific purposes). In accordance with Article 6 (1) of the WFD, a waste material (substance or object) may cease to be waste as defined in the WFD when it has undergone a recovery, including recycling, operation and is commonly used for specific purposes, has a market value, fulfils the technical requirements for the specific purpose and meets existing standards and legislation applicable to products. In addition, criteria shall be set to ensure that the use of the material will not lead to overall adverse environmental or human health impacts. These criteria shall include limit values for pollutants where necessary and shall take into account any possible adverse environmental effects of the material.

When classified as a waste, environmental and health protection aspects of the use of C\&D waste for construction purposes are regulated by national (and EU) waste legislation. Technical (or functional) requirements for the use of C\&D waste for construction purposes are regulated under the Construction Products Regulation (CPR) by harmonised European Product Standards. If a C\&D waste aggregate obtains EoW status and ceases to be waste it becomes a product. In that case it will no longer be regulated by waste legislation, and the environmental and health protection measures embedded in the waste legislation will no longer apply. Instead the use of the material will be regulated entirely by legislation on products. When used for construction purposes the waste-derived C\&D aggregate with EoW status will still be covered by the Construction Products Regulation (which from 1 July 2013 fully replaced the Construction Products Directive, CPD) and also by REACH (possibly with exemptions from some of the provisions). In addition, other EU and national legislation may have a direct or indirect influence on the use or conditions of use of C\&D waste with EoW status. 
Currently, none of the Nordic countries are planning to take advantage of the option to develop national EoW criteria for C\&D waste or other waste materials, and in general Denmark, Finland and Sweden express some concern about environmental and health issues if EU-wide EoW criteria should be developed by the Commission.

Substantial amounts of C\&D waste are recycled/used for construction purposes in Denmark, Finland, Norway and Sweden. In Denmark and Finland, the use of C\&D waste is regulated by specific legislation, whereas it is managed by more general environmental legislation in Norway and Sweden. Each of the Nordic countries has their own functional specifications for $\mathrm{C} \& \mathrm{D}$ waste aggregates to be used for various construction purposes. However, most of the functional, physical specifications can be found in the harmonised European product standards (hENs) on aggregates which have been developed by CEN.

Safe management and recycling/use of C\&D waste have very high priority in both Denmark, Finland, Norway and Sweden, and several studies and initiatives have been or are being carried out in support of these goals. The results of some of these initiatives will be directly applicable to the possible development of EoW criteria for C\&D waste aggregates, in particular crushed concrete.

Denmark, Finland and Norway have developed lists of contaminating substances which are of major concern in relation to management, recycling/use and development of EoW criteria for C\&D waste, in particular crushed concrete. Assessments were also made of the origin of the substances of concern which are practically the same in all three countries. They include: $\mathrm{Cd}, \mathrm{Cr}, \mathrm{Cu}, \mathrm{Hg}, \mathrm{Mo}, \mathrm{Ni}, \mathrm{Pb}, \mathrm{Sb}, \mathrm{Zn}, \mathrm{PCBs}$, PAHs, brominated flame retardants, chloroparaffins, $\mathrm{CFC}, \mathrm{HCFC}, \mathrm{HFC}, \mathrm{SF}_{6}$, hydrocarbons, and phenolic compounds. From a leaching perspective, leaching of sulphate originating from plasterboards mixed in with the concrete could also be mentioned as a potential problem.

Within the Nordic countries several on-going and recently completed projects are aiming to improve the quantity and quality of recycled C\&D waste, including crushed concrete, and to reduce the associated environmental and health impacts.

The Nordic countries have a special interest in protecting the quality of groundwater and surface water. In Denmark, almost all of the drinking water is extracted from groundwater and generally used without treatment (except aeration and filtration), and protection of the groundwater from contamination therefore has high priority. The groundwater quality is already threatened by increasing diffuse contamination of surface soil and from the use of pesticides and fertilisers. It is therefore important to 
control and limit new potential sources of contamination of the groundwater. In Finland, Norway and Sweden much of the drinking water comes from lakes which support fragile ecosystems that are vulnerable to contamination with both inorganic and organic substances, and protection of the surface water quality therefore has particular high priority in these countries. Another specific Nordic aspect is the relatively high level of precipitation in the region which can lead to a high degree of leaching of aggregates used for construction purposes. The low temperatures that occur during the winter in large parts of the Nordic region may also lead to a relatively high degree of disintegration due to freeze/thaw cycles and result in increased exposure of C\&D waste used in bound applications, e.g. as aggregate in concrete. If and when criteria shall be set for the use of C\&D waste and other aggregates as waste materials or as products with EoW status, these issues must be taken into account.

This study primarily addresses the development of EoW leaching criteria aiming at the protection of groundwater, surface water and soil against substances that may be released from the C\&D waste by leaching. However, the protection of human health against exposure through inhalation, ingestion, direct contact with and occupational exposure to C\&D waste is equally important, but it is assumed that existing national legislation and/or guidance in the Nordic countries on maximum contents of (dangerous) substances can be adopted and serve as EoW criteria for this purpose. The EoW criteria should therefore include limit values both on content and leaching of relevant substances.

It is proposed that all risk assessment procedures used to develop EoW criteria, including leaching limit values, should be based on the wellestablished principle of the source-pathway-receptor chain.

If no restrictions or conditions are placed on the uses of waste-derived aggregates which have obtained EoW status, the environmental and health criteria to be fulfilled must take this into account, i.e. they must be based on relatively conservative (if not worst case) application scenarios. If the receptor is groundwater or a surface (fresh)water body, this principle leads to leaching criteria for achievement of EoW status for aggregates that are so restrictive that practically no fractions of C\&D waste will be able to meet them. Those limit values are up to 960 times lower than the EU WAC for landfilling of inert waste. 
It is therefore recommended that if EoW criteria are to be developed for C\&D waste aggregates, then conditions should be placed on the use in order to reduce the potential impact on the environment and human health. Such conditions could e.g. include that the material can only be used for specified purposes, that it is an obligation to remove the material after its service lift has ended, a minimum distance to the groundwater surface level, a minimum distance to surface water, restrictions on the height, length and width of the application, restrictions on the allowed rate of infiltration, and a minimum distance to drinking water extraction wells. The conditions can reduce both the impacts/risks associated with leaching of substances and the risks associated with direct contact with the materials.

It is further recommended that a well-established and acknowledged methodology based on a stepwise procedure is used to develop leaching limit values for achievement of EoW status (or for use under waste legislation) for $\mathrm{C} \& \mathrm{D}$ waste. The steps in the procedure are:

- Step 1: Description of the application type and the imposed conditions.

- Step 2: Description of the relevant receptor(s) and the primary water quality criteria.

- Step 3: Description and modelling of the source term.

- Step 4: Description and modelling of the migration of substances from the source to the point of compliance (pathway).

- Step 5: Assessment of the impact at the receptor and reverse modelling or iteration to adjust the source term.

- Step 6: Transformation of source term criteria to specific limit values.

- Step 7: Assessment of the resulting limit values and possible repetition of the stepwise procedure.

- Step 8: Taking other considerations into account e.g. to modify relatively high limit values for some substances.

This methodology is based on the same principles as the method used to develop the EU waste acceptance criteria for landfilling. The method has also been adopted officially in Denmark and Sweden. 
The methodology has been demonstrated on 4 different examples of use scenarios for $C \& D$ waste. Some of the resulting limit values are relatively high (higher than the EU WAC for inert waste), and it is therefore recommended that other issues are also considered. Some of these issues could be:

- The reluctance to create a number of potential landfills (a requirement could be that the leaching (or content) limit values should not exceed those for landfilling at inert waste landfills or at non-hazardous waste landfills receiving stable, non-reactive hazardous waste).

- The reluctance to have EoW limit values for C\&D waste that are higher than or even equal to national limit values for utilisation of waste materials or soil in construction engineering works (adjustment may be required even though the conditions may be different).

- The risk that a substance that has a high limit value because of a low impact at the POC may influence other substances and for example increase their solubility and leachability. This could e.g. be the case with high concentrations of DOC, chloride and sulphate.

- The risk of causing damage to structures or processes (sulphate in higher concentrations may cause corrosion of concrete, and if biodegradable material is present, it may form toxic and malodorous hydrogen sulphide). This may in some cases call for a reduction of calculated limit values for sulphate.

In relation to development of EoW criteria, a testing framework including both determination of leaching and content of substances as well as the development of a dossier for documentation is proposed and described.

Finally some recommendations of requirements on input materials and pre-treatment of C\&D waste (crushed concrete) are given. It is recommended that strict controls should be placed on the quality of the input materials. The Nordic countries (Denmark, Finland, Norway and Sweden) already have procedures for selective demolition, depollution of buildings and on-site sorting of C\&D waste/concrete that, if they are followed and properly inspected, probably will be sufficient to ensure a good quality input material. Such procedures can, if they are followed strictly, effectively reduce the contamination of crushed concrete originating from external sources (other materials including e.g. asbestos, insulation materials, and plaster boards, paint, diffusing contaminants 
(PCB, Hg)), but not sources of contamination within the concrete itself (originating from raw materials, e.g. coal fly ash). Studies aimed at improving the demolition and renovation procedures and ensure a high quality of C\&D with the lowest possible risk of unacceptable contamination are on-going e.g. in Denmark, and recommendations of new procedures should await the outcome of these studies.

The procedures suggested by the EU Commission's Joint Research Centre, Institute for Prospective Technology Studies (Delgado et al., 2009) for C\&D waste (a controlled selective demolition procedure) may be applicable - in conjunction with EoW criteria on content and leaching of relevant substances, with the important addition that factory production control testing and compliance testing on a regular basis will be required for crushed concrete products based on all categories of input materials to ensure that established EoW limit values on content and leaching of potentially harmful substances are met. The procedures should be described in much more detail, and both guidelines and rigorous control measures will be required.

The technical requirements on the content of impurities in product standards and guidelines (e.g. for road construction) should be reviewed and possibly revised. The need for requirements on sorting and crushing procedures should be considered. Particular efforts should be made to ensure that, for example, the PCB-containing waste and gypsum/plasterboards are kept out of the product stream if they are not caught by the selective demolition procedures or sorted out at construction sites. 


\section{Introduction}

\subsection{Background}

The Waste Framework Directive (WFD) 2008/98/EF includes the option to set so-called End-of-Waste (EoW) criteria under which specified waste fractions shall cease to be waste. If these criteria are fulfilled, the material will no longer be classified as a waste but rather become a product subject to free trade and use (albeit for specific purposes). The basic criteria to be fulfilled are related to the specific usefulness of the material, the market needs for it, the technical properties of the material, and the risk of adverse environmental and human health impacts, including the need to set limit values for pollutants (see section 2.1).

Following an initial study (Delgado et al., 2009; IPTS, 2009), the EU Commission is currently assessing the suitability of various waste streams as candidates for non-waste classification through the development of specific criteria for achievement of EoW status (EoW criteria). One of the waste streams under consideration in this respect is construction and demolition (C\&D) waste, which may be used as aggregates in construction works. The initial study which was carried out by the EU Joint Research Centre (JRC), Institute for Prospective Technical Studies (IPTS), includes a first proposal for an overall methodology for development of EoW criteria for C\&D waste. If the EU Commission decides to move forward and initiate development of EU-wide EoW criteria for aggregates, including C\&D waste, it will become important for the Nordic EU Member States to ensure that Nordic concerns and Nordic policies with respect to the protection of the environment and human health are taken into account.

C\&D waste is a major waste stream in most of the Nordic countries as it is in most EU Member States. According to the waste regulation in several of the Nordic countries it is already possible to use C\&D waste in construction work as a replacement of virgin material. The environmental authorities in the Nordic countries can benefit from mutual exchange of information on these activities and also from a common effort addressing the development of environmental protection criteria to be fulfilled by C\&D waste (and other aggregates), to obtain EoW status. It is expected that experience from related activities and legislation such as the existing 
Danish criteria for utilisation of MSW incinerator bottom ash and coal fly ash and the new Swedish guidelines for utilisation of waste as construction material can provide some inspiration in this context.

This study was carried out to provide an overview of the current situation in the Nordic countries concerning EoW and criteria for utilisation of C\&D waste as aggregates and to develop proposals for EoW criteria for such use of C\&D waste. The results of the project should support the Nordic countries in possible future negotiations at EU level on EoW criteria for aggregates and C\&D waste. This report presents the results of the study.

\subsection{Objectives}

The main objectives of this study have been

- to provide the Nordic EoW Group and the responsible environmental authorities in individual Nordic countries with a status and overview of the current situation concerning the extent and regulation of recycling of C\&D waste, and in particular crushed concrete, in the Nordic countries

- to develop proposals for methods for development of EoW criteria (with particular focus on leaching limit values) for C\&D waste aggregates which can ensure adequate protection of groundwater, surface water and soil, and which can support the position of the environmental authorities in the Nordic countries if and when discussions on common EU EoW criteria for C\&D waste are launched by the EU Commission. This part of the project will primarily address crushed concrete, although the leaching limit values in principle are independent of type of aggregate in question.

\subsection{Approach}

Chapter 2 discusses European legislation related to EoW for C\&D waste, including the detailed requirements for achievement of EoW status laid down in the WFD. The transition from waste legislation to product legislation for C\&D waste achieving EoW status is discussed, and the possible influence of EU product legislation, in particular CPD/CPR and REACH, on the use of C\&D waste with EoW status is also discussed. Some other EU 
Directives (e.g. the Water Framework Directive and the Groundwater Directive) that may influence the EoW criteria and the conditions for use are also mentioned.

Chapter 3 and Chapter 4 provide information on the current situation concerning EoW strategy and the current situation concerning recycling of C\&D waste and other aggregates in the Nordic countries. Detailed information can be found in Appendices 1 to 5 on Denmark, The Faroe Islands, Finland, Norway and Sweden. No information was provided for Iceland. Chapter 3 summarises the current status and policies of each of the Nordic countries on EoW in general and C\&D waste/aggregates in particular. Chapter 4 summarises the regulations and legislation and the functional criteria for use of recycled C\&D waste and other aggregates for construction purposes in the Nordic countries. Some of the most important studies and data regarding potential health and environmental problems related to utilisation of $C \& D$ waste are listed (with primary focus on crushed concrete), and the substances of most concern in relation to environmental and health impacts in the Nordic countries are presented.

Chapter 5 presents and demonstrates a methodology for development of EoW criteria for C\&D waste with particular focus on leaching that may be applicable under Nordic conditions. First, the overall methodology proposed by the European Commission (JRC-IPTS) in 2010 is presented and discussed, and its compatibility with Nordic conditions and environmental policies is commented. Then a methodology that may be suitable under Nordic conditions, with special focus on the release of substances to groundwater, surface water and soil, is developed and proposed: Potential use scenarios for C\&D waste (crushed concrete) as construction materials and associated potential impacts on the environment and human health are presented, and a conceptual model (based on the sourcepathway-receptor chain) for risk-based calculation of leaching limit values is developed and transformed into an operational format. Assumptions, pre-conditions and choices are discussed. The influence on the resulting leaching limit values of various conditions/restrictions on the use of C\&D waste with EoW status is discussed, and a few selected combinations of use scenarios and conditions/restrictions are subsequently selected and used in model calculations to illustrate the applicability of the methodology. The modelling results are presented. The need for pretreatment and control measures for C\&D waste to be considered for EoW assessment is also discussed.

Chapter 6 presents the conclusions of the study as well as some recommendations, based on the previous chapters. 



\section{Legislation related to EoW for C\&D waste}

This chapter briefly describes some of the legislation which will be of relevance regarding the regulation of the use of C\&D waste aggregates and $C \& D$ aggregates if/when they cease to be waste.

\subsection{The requirements laid down in Article 6 of the Waste Framework Directive}

According to Article 6 (1) of the WFD, a waste material (substance or object) may cease to be waste as defined in the WFD when it has undergone a recovery, including recycling, operation and complies with specific criteria to be developed in accordance with the following conditions:

- The material is commonly used for specific purposes.

- A market or demand exists for such a material.

- The material fulfils the technical requirements for the specific purposes and meets the existing legislation and standards applicable to products.

- The use of the material will not lead to overall adverse environmental or human health impacts.

The criteria shall include limit values for pollutants where necessary and shall take into account any possible environmental effects of the material.

On request from the EU Commission's DG Environment, the Joint Research Centre, Institute for Prospective Technological Studies has carried out two studies where the first was aimed at defining the concept of EoW and developing a general classification methodology (IPTS, 2008) and the second was aimed at identifying waste streams suit-able for non-waste classification (IPTS, 2009). The latter study has identified three different waste streams: 
1. Streams that are in line with the basic principles of EoW and suited for further EoW criteria assessment.

2. Streams that may be in line with the principles.

3. Streams that are not considered appropriate for EoW classification.

The first category of waste streams has been further divided into two subcategories, namely:

- I.1): Streams used as feedstock in industrial processes, a pathway that controls the risks of health and environmental damage. These streams include metal scrap of iron and steel, aluminium, copper, plastics, paper, textiles, glass, metal scrap of zinc, lead and tin, other metals.

- I.2): Streams used in applications that imply direct exposure to the environment. In these cases, the EoW criteria to be developed in the further assessment shall include where necessary limit values for leaching pollutants, taking into account any possible adverse environmental and health effects. The streams in this subcategory are: Construction and demolition (C\&D) waste aggregates, ashes and slag, bio-waste materials stabilised for recycling.

Steps have been taken by the EU Commission to initiate the development of EoW criteria for waste fractions belonging to waste stream I.1, i.e. wastes that are not used in direct contact with soil and the environment. ${ }^{2}$

It is expected that the EU Commission at a later date may wish to develop EoW criteria for the waste streams belonging to subcategory I.2. These waste types include major streams such as C\&D waste and bottom ash from MSW incinerators, which are typically used as aggregates in civil engineering constructions works (e.g. as sub-base in road construction), replacing and saving virgin raw materials (sand, gravel, rocks). These waste fractions constitute large proportions of the waste streams generated in the Nordic countries and in Europe, and they are generally containing and probably also releasing larger amounts of contaminating substances than the virgin materials they may replace. Since most of the applications of these waste materials, both as unbound (granular) and

2 On 8 April 2011, Council Regulation (EU) 333/2011 of 31 March 2011 establishing criteria determining when certain types of scrap metal cease to be waste under Directive 2008/98/EC of the European Parliament and of the Council, was published in the official Journal. 
bound (as part of concrete or asphalt) aggregates, will be directly or indirectly exposed to soil, water and the external environment, reclassification and use of C\&D aggregates and bottom ash as products may lead to unacceptable impacts on the environment, in particular surface water and groundwater, unless the EoW criteria ensure a high level of protection. As long as the materials remain classified as wastes, EU Member States set the requirements for use of aggregates in construction work - and thus the protection level - as part of the national waste regulations.

It should be noted that Article 6 (2) of the WFD states that "Where criteria have not been set at Community level under the procedure set out in paragraphs 6 (1) and 6 (2) [of the WFD], Member States may decide case by case whether certain waste has ceased to be waste taking into account the applicable case law. They shall notify the Commission about such decisions in accordance with Directive 98/34/EC of the European Parliament and the council of 22 June 1998 laying down a procedure for the provision of information in the field of technical standards and regulations and of rules on information on Information Society Services where so required by that Directive." None of the Nordic countries have taken such action.

This study is aimed primarily at issues associated with indent (d) of Article 1 of the WFD - protection of human health and the environment. It may, however, be mentioned that whereas several streams of C\&D waste and in particular aggregate fractions of crushed concrete most likely fulfil the requirements listed under indent (a) - the material is commonly used for specific purposes - and indent (c) - the material fulfils the technical requirements for the specific purposes and meets existing legislation and applicable standards (although the implications of REACH may require some clarification, see section 2.5) - there is some discussion as to whether recycled C\&D waste actually meets the condition listed under indent (b): A market or demand must exist for the material. It is not clear whether this means that the material to be used with EoW status should have a real positive monetary value, or if it is sufficient that an alternative cost of landfill that would have to be paid if the material had remained a waste, and not been recycled, is saved. The situation today in the Nordic countries is that part of the incentive for recycling of C\&D waste is the saved cost of landfilling, not the least the landfill tax. The EU Commission has not (yet) provided a consolidated opinion on this (IPTS, 2011). It must also be ensured that the waste material in question comply with other existing legislation. 


\title{
2.2 The requirements laid down in Article 5 of the WFD (on by-products)
}

An alternative route for a material to cease being a waste is described in Article 5 of the WFD which states:

\begin{abstract}
"1. A substance or object, resulting from a production process, the primary aim of which is not the production of that item, may be regarded as not being waste referred to in point (1) of Article $3^{3}$ but as being a by-product only if the following conditions are met:
\end{abstract}

(a) further use of the substance or object is certain;

(b) the substance or object can be used directly without any further processing other than normal industrial practice;

(c) the substance or object is produced as an integral part of a production process; and

(d) further use is lawful, i.e. the substance or object fulfills all relevant product, environmental and health protection requirements for the specific use and will not lead to overall adverse environmental and/or health impacts.

2. On the basis of the conditions laid down in paragraph 1 , measures may be adopted to determine the criteria to be met for specific substances or objects to be regarded as a by-product and not as waste referred to in point (1) of Article 3. Those measures, designed to amend non-essential elements of this $\mathrm{Di}$ rective by supplementing it, shall be adopted in accordance with the regulatory procedure with scrutiny referred to in Article 39 (2)."

So far, one type of waste-derived aggregate, blast furnace slag, has been assessed by the EU Commission and found suitable for re-definition as a by-product. In Communication from the Commission to the Council and the European Parliament on the Interpretative Communication on waste and by-products (COM(2007) 59 final of 21.2.2007), the EU Commission states that: "Blast furnace slag is produced in parallel with hot iron in a blast furnace. The production process of the iron is adapted to ensure that the slag has the requisite technical qualities. A technical choice is made at the start of the production process that determines the type of slag that is produced. Moreover, the use of the slag is certain in a number of clearly defined end uses, and demand is high. Blast furnace slag can be used directly at the end of the production process, without further processing that is not an integral part of this production process (such as crushing to

${ }^{3}$ Article 3 (1): "waste" means any substance or object which the holder discards or intends or is required to discard. 
the appropriate particle size). This material can therefore be considered to fall outside of the definition of waste."

Requirement (d) above is the same as requirement (d) for achievement of EoW status in Article 6 (1) but it does not call for limit values for pollutants as may be required for EoW assessment.

Since C\&D waste generally does require a substantial pre-treatment which cannot be regarded as an integral part of the production process, classification of C\&D waste as a by-product is most unlikely. The by-product option will not be addressed further in this study.

\subsection{The transition from waste legislation to product legislation}

When classified as a waste, environmental and health protection aspects of the use of C\&D waste for construction purposes are regulated by national (and EU) waste legislation. Technical (or functional) requirements for the use of C\&D waste for construction purposes are regulated under the Construction Products Regulation (CPR) by harmonised European Product Standards. The harmonised European standards for aggregates distinguish between primary, secondary and recycled aggregate (see Terms and Definitions under Aggregate) and thus cover both waste materials and products used in construction. Generally, all three types must fulfil the same technical requirements in order to be used as aggregates in the European common market. One of the standards has been revised to include additional clauses for recycled aggregates (Delgado et al., 2009).

If a C\&D waste aggregate obtains EoW status and ceases to be waste in accordance with Article 6 (1) of the WFD and any additional criteria that may be developed, it becomes a product. In that case it will no longer be regulated by waste legislation, and the environmental and health protection measures embedded in the waste legislation will no longer apply. Instead the use of the material will be regulated entirely by legislation on products. When used for construction purposes the waste-derived C\&D aggregate with EoW status will still be covered by the Construction Products Directive, CPD (from 1 July 2013 replaced by the Construction Products Regulation, CPR) and by REACH (possibly subject to the exemptions described therein). In addition, other EU and national legislation may have a direct or indirect influence on the use or conditions of use of C\&D waste with EoW status. The product legislation (CPR and REACH) and a few of the Directives that may influence the EoW criteria are discussed in the following sections. 


\subsection{The Construction Products Directive/Regulation}

The marketing and use of a waste-derived C\&D aggregate which obtains EoW status and becomes a construction product will, as mentioned above, still be regulated by the CPR as far as the functional criteria and CE marking are concerned. Currently CEN is working under mandates from the EU Commission (based of the CPD) to implement Essential Requirement no. 3 addressing health, hygiene and the environment (in the CPR referred to as Basic Requirement no. 3) into the various product standards describing the conditions for CE marking. The product standards will describe which (harmonised) test standards must be used at EU level to measure the potential release to soil, groundwater and surface water (as well as to indoor air, but that is not relevant in this context). The criteria to be met by the test results to allow various uses of the products are, however, not set at EU level - they depend on national regulation in each member state (and associated states). If such criteria exist, they would presumably provide the necessary protection of soil, groundwater and surface water regardless of the origin of the construction products.

Very few of the EU Member States (and none of the Nordic countries) have actually set general criteria for the use of construction products. The notable exception that has such legislation is the Netherlands (SQD, 2007) and to some extent also Germany. This means that in all the Nordic countries (and most other European countries), a C\&D material with EoW status may no longer be subject to any environmental quality criteria or specific use conditions, except for those laid down in the requirements for obtaining the EoW status itself.

One drawback of legislation based on the CPD was that the testing and CE marking only referred to the service life of the construction products. The CPD was actually replaced by the Construction Products Regulation (CPR) on 9 March 2011 (but with a transition period that effectively allowed CE marking and marketing of construction products in accordance with the CPD until 1 July 2013). In contrast to the CPD, the CPR addresses the entire lifecycle of the construction products, but most likely it will take 5 to 10 years to implement this into the product standards which are based on the conditions dictated by the CPD. In addition, under the CPR the setting (or not setting) of environmental protection criteria is still left to the national authorities in each member state. 
Based on the above it may be concluded that in the Nordic countries the protection of the environment and human health from the potential release from $C \& D$ products with EoW status used in construction may not be fully addressed by the CPR within a foreseeable timeframe. This must be taken into account if and when setting the criteria and conditions for obtaining EoW status.

\subsection{The REACH Regulation}

The REACH regulation ((EC) No 1907/2006 of the European Parliament and the Council) lays down specific duties and obligations on manufacturers, importers and downstream users of substances on their own, in preparations and in articles. The objective is to ensure a high level of protection of human health and the environment as well as the free movement of substances, on their own, in preparations and in articles, while enhancing competitiveness and innovation. Any manufacturer or importer of a substance, either on its own or in one or more preparations in quantities of one tonne or more per year shall submit a registration to the European Chemicals Agency (ECHA). REACH focuses on substances. The main principle of the legislation is that if no data are provided, the product cannot be placed on the market (Delgado et al., 2010).

Waste as such is not covered by REACH. When a waste becomes a product, it automatically becomes regulated by REACH but it may or may not be exempted from some of the registration provisions, downstream user obligations and evaluation requirements of the REACH regulation. Some aspects of the relationship between the REACH regulation and waste-derived aggregates (in particular C\&D waste) with EoW status are addressed below.

In principle, REACH applies to all substances. However, the regulation exempts certain substances that are adequately regulated under other legislation or present low risks to human health and the environment. A number of primary ${ }^{4}$ (non-waste) aggregates are, for example, exempted from registration in accordance with Article 2 (7)b, downstream user obligation and evaluation, because they fall into the exemption in Annex $\mathrm{V}$ (Clause 7) to REACH, substances which occur in nature, if they are not chemically modified. The raw materials used in the production of primary aggregates are naturally occurring materials or minerals (e.g. stone,

${ }^{4}$ See Terms and Definitions under Aggregate. 
sand). The minerals, for example sand, can be used immediately after extraction or have to be processed, crushed and sieved. The production process involves only physical transformation of the mineral according to technical specifications. The chemical nature of the mineral is maintained (Delgado et al., 2007).

Article 2(2) of REACH provides that "waste as defined in Directive 2006/12/EC [now 2008/98/EC] of the European Parliament and of the Council is not a substance, preparation or article within the meaning of Article 3 of this Regulation." Therefore, REACH requirements for substances, mixtures and articles do not apply to waste (at least not in full, see ECHA (2010)). This will, of course, change when a waste becomes a product as a result of an EoW assessment, unless the material can be regarded purely as an article, i.e. an object for which the shape, surface or design is more relevant for its function than its chemical composition, in which case it may be exempted from registration under REACH.

In a recent guidance document, ECHA (2010) has stated that for the sake of consistency and enforceability, all forms of recovery, including mechanical processing, are considered as a manufacturing process whenever, after having undergone on or several recovery steps, they result in the generation of one or several substances as such or in a mixture or in an article that have ceased to be waste.

In the same guidance document, ECHA presents the following considerations concerning the need to register recovered (waste-derived) aggregate products (see Box 1 below):

\section{Box 1}

"Recovered aggregates [with EoW status as products] should be understood in the following as covering aggregates resulting from the processing of inorganic material previously used in construction (e.g. concrete, stones), as well as certain aggregates of mineral origin resulting from an industrial process involving thermal or other modification (e.g. unprocessed slag, waste from processing of slag, fly ash).

The question was raised whether such recovered aggregates can be seen as articles (see terms and definitions) or whether they are substances on their own or in a mixture.

[...] 
...Registration of substances in articles is only required if they are intended to be released under certain conditions as specified in Article $7(1)^{5}$ of REACH or if ECHA has taken a decision to require registration pursuant to Article 7(5) of REACH. Only in these limited cases, there should be the need to establish whether Article 2(7) $d^{6}$ applies as the recovery operator has to comply with the provisions under Article 7 of REACH regarding substances in articles. Should a recovery operator for any reason not be able to rely on Article 2(7)d of REACH, he may however be eventually exempted from registration pursuant to Article $7(6)$ of REACH if the substance has already been registered for that use...

$[\ldots]$

Recovered aggregates from construction consist of concrete, natural stones, masonry, ceramics (e.g., roofing tiles) and/or asphalt, either alone or in certain cases mixed. They can have diverse applications, such as in civil engineering works, in roads and as railway ballast. The main function of this application is to provide stability and resistance to degradation/fragmentation. If for this function the shape, surface or design is more important than the chemical composition, the recovered aggregates would be considered as articles. By definition, this would however only be the case if the shape, surface or design of the material has been deliberately determined and given during its production (e.g. in order to meet certain recognised aggregate standards such as EN 12620, EN 13043 or EN 13242). If for this function the shape, surface or design does not determine the function of the material to a greater degree than its chemical composition, then the aggregate would not be in line with the article definition, and should thus be seen as a substance on its own or in a mixture. Examples of different recovered aggregates are given below:

${ }^{5}$ Article $7(1)$ states that any producer or importer of articles shall submit a registration to the Agency for any substance contained in those articles, if both the following conditions are met:

(a) the substance is present in those articles in quantities totalling over 1 tonne per producer or importer per year;

(b) the substance is intended to be released under normal or reasonably foreseeable conditions of use.

A submission for registration shall be accompanied by the fee required in accordance with Title IX. ${ }^{6}$ Article 2(7)d of REACH states that substance, on their own, in preparations or articles, which have been registered in accordance with Title II (of REACH) and which are covered in the community shall be exempted from Titles II (Registration), V (Downstream users) and VI (Evaluation) if:

i. the substance that results from the recovery process is the same as the substance that has been registered in accordance with Title II; and

ii. the information required by Articles 31 and 32 relating to the substance that has been registered in accordance with Title II is available to the establishment undertaking the recovery. 
Aggregates from construction and demolition waste

Particles from aggregates from construction and demolition waste are produced with specific shape and surface characteristics depending on their application, like e.g. in asphalt pavements. The shape of such a particle is described using the ratio of the longest and smallest dimension of the particle. EN Standards 933-3 and 933-4, for instance, describe methods to determine the shape of such particles. The surface of such a particle is defined by its micro- and macrorugosity (i.e. variations in the height of a surface at different scales), which are measured as described by the EN Standards 1097-8 and 933-5 respectively. Shape and surface of a particle from aggregates from construction and demolition waste determine its function to a greater degree than the chemical composition of the particle. The essential chemical properties are restricted to a maximum of allowed solubility - if the aggregate is soluble it cannot fulfil its function - and are less important than the shape and surface. These particles are therefore considered to be articles according to the article definition under REACH.

$[\ldots]$

For recovered aggregates that are substances on their own or in a mixture it will be necessary to determine the exact status of the material under REACH and to verify whether the conditions of Article 2(7)(d) apply. If the substance as such or in a mixture is not exempted from registration, late pre-registration - provided that all conditions under Article 28(6) are fulfilled - or decreasing the volume below 1 tonne/year until the substance has been registered (by any actor) are possible alternatives for potential registrants.

In determining the exact status of the recovered aggregates, the following considerations should also be taken into account:

a) Some of these materials, such as certain slags and residues of various melting or metallurgic processes, will normally be $\mathrm{UVCB}^{7}$ substances. There may however also be cases where such substances are multi-constituent substances (e.g. when the substance is the result of a chemical reaction during recovery and consists of a limited number of constituents).

b) Some recovered aggregates may consist of materials which are exempted from registration, evaluation and downstream user obligations under other

${ }^{7}$ Substances of Unknown or Variable Composition, Complex reaction or Biological materials, also called UVCB substances cannot be sufficiently identified by their chemical composition, because (ECHA, 2010):

- the number of constituents is relatively large and/or

- the composition is, to a significant part, unknown and/or

- the variability of the composition is relatively large or poorly predictable.

For such substances, further identifiers have to be considered such as sources of origin or type of production processes. 
REACH provisions, in particular Annex V. Examples include minerals which are not chemically modified (e.g. natural stones) or substances occurring in nature which are not chemically modified and do not meet the criteria for classification as dangerous (e.g. wood).

c) In the case where recovered aggregates consist of one main constituent (possibly with impurities), they will be a mono-constituent substance. In case they consist of several constituents, those constituents may either be seen as separate substances (i.e. then the recovered aggregate will be a mixture) or as constituents of one complex UVCB substance. As outlined in section 2.2.3 [in ECHA (2010)], it is up to the manufacturer of the recovered material to decide whether the recovery operation resulted in a substance (mono-constituent, multi-constituent or UVCB) as such or in a mixture.

In determining the registration status of the recovered aggregates, information on the origin may be important in order to establish which constituents may be present in the material and whether they should be seen as impurity or separate substance. To identify the substances, that in principle, are subject to registration and analysis of the waste material will only be necessary insofar as constituents may in normal cases occur in quantities above $20 \%{ }^{8}$ (or are intended to be present in the recovered material - however, in this case the recovery operator should know about their presence).

The manufacturers of recovered aggregates should also have information on the identity and quantities in which hazardous minor constituents or impurities are present in the recovered aggregate to the extent needed as described in the section on impurities (chapter 2.2.3 in the ECHA guidance document)."

In view of the above it seems most likely that that C\&D waste (crushed concrete) can be considered an article (i.e. its function depends on its shape, surface or design rather than its chemical composition) with respect to REACH.

${ }^{8}$ In cases where such constituents are regularly close to this limit, it is recommended to take a safe approach and consider the constituent as a separate substance. Where constituents exceed $20 \%$ only in rare, individual batches which cannot be realistically expected under normal conditions, those constituents do not have to be considered as separate substances. It is also not necessary to examine each individual batch of waste material for the presence of such constituents. 
In another guidance document, "Guidance on requirements for substances in articles, version 2, April 2011", 9 ECHA lists the specific obligations that an article has to meet under REACH with respect to substances. The main obligations described in the guidance document are summarised in Table 1.

\begin{tabular}{|c|c|c|c|}
\hline Obligation & $\begin{array}{l}\text { Registration of } \\
\text { substances in articles }\end{array}$ & $\begin{array}{l}\text { Notification of } \\
\text { substances in articles }\end{array}$ & $\begin{array}{l}\text { Communication of } \\
\text { information on } \\
\text { substances in articles }\end{array}$ \\
\hline $\begin{array}{l}\text { Legal basis in REACH } \\
\text { Legislation }\end{array}$ & Article $7(1)$ & Article $7(2)$ & Article 33 \\
\hline Actors concerned & $\begin{array}{l}\text { Article producers and } \\
\text { article importers }\end{array}$ & $\begin{array}{l}\text { Article producers and } \\
\text { article importers }\end{array}$ & Article suppliers \\
\hline Substances concerned & $\begin{array}{l}\text { Substances intended to } \\
\text { be released from articles }\end{array}$ & $\begin{array}{l}\text { Substances included } \\
\text { in Candidate list of } \\
\text { Very High Concern for } \\
\text { authorisation }\end{array}$ & $\begin{array}{l}\text { Substances included } \\
\text { in Candidate list of } \\
\text { Very High Concern for } \\
\text { authorisation }\end{array}$ \\
\hline Tonnage threshold & 1 tonne per year & 1 tonne per year & \\
\hline $\begin{array}{l}\text { Concentration in article } \\
\text { threshold }\end{array}$ & - & $0.1 \%(w / w)$ & $0.1 \%(w / w)$ \\
\hline \multicolumn{4}{|c|}{ Exemption from obligation possible on the basis of: } \\
\hline $\begin{array}{l}\text { Substance already } \\
\text { registered for that use }\end{array}$ & Yes & Yes & No \\
\hline Exposure can be excluded & No & Yes & No \\
\hline
\end{tabular}

"Intended" release appears to infer that the release of a substance is part of the function of the article, and hence C\&D waste does not require registration on the basis of Article 7(1) - some leaching may occur, but it is not "intended". The passing of EoW criteria should effectively prevent any obligations associated with Article 7(2) and Article 33. This presumes that the EoW criteria include appropriate restrictions on the content and leaching of substances, and if they are set in accordance with the principles proposed in this report (see Chapter 5) and include routine control, they will/should certainly exclude the presence of substances of very high concern above the limit values shown in Table 2.1. The same requirements would also ensure that the C\&D waste with EoW status would indeed be an article rather than a substance or a mixture/UVCB.

9 The guidance document is published with a warning from ECHA that the document in its current state did not find full support by consulted national authorities of EU/EEA Member States and that companies therefore may face diverging practices as to some of the its aspects. 
Again with reference to the EoW criteria, it is not likely that the production of a Safety Data Sheet (SDS) in accordance with Article 31 of REACH will be required for C\&D waste with EoW status obtained in accordance with the recommendations in Chapter 5. However, as noted in ECHA (2010), a manufacturer may for commercial reasons choose to produce a SDS at the request of a costumer, even if he is not legally obliged to do so. Much of the information required for an SDS would be available from the dossiers required for attainment of EoW status and/or for CE marking under the CPR.

The REACH rules are relatively new and rather complicated, and a starting point for a producer/supplier (or an authority) could always be to contact ECHA to find out if a given aggregate with EoW status has already been registered and if it has, to find out which status it has, and which information is available.

\subsection{Other EU directives that may influence EoW conditions for aggregates}

The Water Framework Directive (2000/60/EC) obliges EU Member States to improve the quality of natural water bodies, in particular groundwater. Both this general requirement and the national requirements arising from the implementation of the Water Framework Directive and its daughter directive, the Groundwater Directive $(2006 / 118 / \mathrm{EC})$ in the member and associated states must be taken into account when setting the primary water quality criteria as e.g. described in chapter 5 . 



\section{EoW for aggregates in the Nordic countries: Status and policy}

This chapter briefly presents the status of EoW and EoW legislation as well as the current policy on EoW in each of the Nordic countries.

\subsection{Denmark}

Article 6 of the WFD on EoW was implemented into Danish waste legislation by 1 January 2010, and the provisions on EoW may currently be Denmark, the municipalities are responsible for evaluations regarding possible EoW status for specific waste streams.

So far, no EoW criteria for C\&D waste or any other aggregates (or other wastes) have been developed in Denmark. The Danish Environmental Protection Agency has raised a number of issues regarding the development of EoW criteria at EU level for aggregates and other waste fractions that may be used in direct contact with the environment. The main points are as follows:

- Article 6 in the WFD provides an option to establish common EoW criteria for selected waste streams within the EU, but there is no obligation to do so.

- Article 6 in the WFD implies that EoW criteria must provide a high level of environmental protection.

- A the legal basis of the WFD is Article 175 of the Treaty, it is the Danish position that a decision on EoW criteria will only constitute a minimum regulation, meaning that the Member States therefore will be permitted to adopt more stringent requirements cf. Article 176 of the Treaty, provided there is an environmental justification for such national regulation.

- For waste fractions such as e.g. aggregates where possible future EoW products will be used in direct contact with soil and thus the 
environment, it is difficult to imagine common criteria which can protect the environment - not the least the groundwater throughout Europe, due to differences in climate, soil properties, background levels of substances in the environment, etc.

- A crucial prerequisite for maintaining a high level of protection is that inspections ensure that EoW products meet specific criteria based on a high level of protection of environment and human health. In this context it should be carefully considered whether the necessary inspections are possible in light of the significant resources it requires.

- Before embarking on establishing EoW criteria, the relation of the criteria to other legislation must be clarified, including whether or not potential EoW products based on waste aggregates will be subject to the provisions under REACH.

\subsection{Faroe Islands}

No concrete steps have been taken towards the development of an EoW policy. The Faroe Islands are not a member of the EU and are hence not bound by the EU Waste Framework Directive.

\subsection{Finland}

In Finland, the waste legislation is currently under revision. It is suggested to implement the EoW concept in the current revision of the waste legislation as follows:

- The by-product and EoW criteria will be implemented as such by a Government Decree in accordance with the Waste Framework Directive and later Commission Regulations establishing specific criteria determining when certain types of materials cease to be waste.

- The by-product criteria can be applied in the legal praxis, e.g. in the environmental permit procedure for a specific waste. By-product criteria might also be given by Government Decree. Consequently meaning that the by-products are not considered wastes and will not be subject to waste regulations. By-products will be comparable to products which means that the product liability regulation of concern applies. 
- At a national basis a Government Decree (establishing national EoW criteria) can also be given for materials which are not regulated as EoW materials by a Commission regulation. However, these national EoW criteria need to be notified by the Commission. The EoW criteria are material specific and cannot be applied in the legal praxis. Especially the monetary value of the material is seen as important to ensure that there is a market or demand for the material (as stated in Article 6 of the Waste Framework Directive (2008/98/EC)).

A pilot study on the applicability of the EoW methodology for soil material arising during construction has been carried out by the Finnish research institutes SYKE and VTT and was financed by the Finnish Ministry of the Environment. The pilot study focused especially on non-excavated soil like material to be removed due to construction activities, typically uncontaminated. The study also included waste rock materials from the production of natural stones. The aim was to list aspects of importance and challenges in evaluating the applicability of the EoW concept for these waste streams.

As a result this pilot project identified the following main obstacles in the use of the EoW criteria for these specific waste materials (Annon., 2010):

- Lack of an exact definition of the waste flow ensuring specific waste characteristics (this is due to the fact that the material is site specific and not continuously arising from a certain waste process where the quality is controlled, and the fact that there is no clear stakeholder responsibility for the material quality).

- No clear market with monetary value currently exists.

One of the key areas of the "Finnish National Waste Plan to the year 2016" is the sustainable management of waste from construction and demolition. The plan especially promotes waste separation and reuse/recycling. To support this target, the Finnish Ministry of the Environment initiated in 2006 a "UUMA (= advanced materials technology for infrastructure building) development programme" for 2006-2010. One of the aims of the UUMA-programme was to highlight the legislative boundaries, and primarily evaluate the suitability of the EoW-concept for some potential candidate waste streams. The UUMA-programme also included an approach for evaluation of environmental acceptability of by-products in earth construction which can be used as a base in the development of the national EoW criteria. 


\subsection{Iceland}

No information has been provided on Iceland.

\subsection{Norway}

The Norwegian Ministry of the Environment stated in the Government's Environmental Policy and the state of the Environment in Norway (20062007) that the objective of Norway's waste management policy is to make more use of the resources in waste and that legislation, among other policy instruments, will be used to make it possible to include more waste fractions in the waste cycle and use them as raw materials. National targets are:

- The growth in the quantity of waste generated will be considerably lower than the rate of economic growth.

- The proportion of waste recovered will be raised to about $75 \%$ of the total quantity in 2010 and subsequently to $80 \%$. This is based on the principle that the quantity of waste recovered should be increased to a level that is appropriate in economic and environmental terms.

- Hazardous waste will be dealt with in an appropriate way so that it is either recovered or sufficient treatment capacity is provided within Norway. The generation of each type of hazardous waste will be reduced by 2020 compared with 2005 level.

At present, Norway does not have a specific strategy for End-of-Waste. In Norway classification of materials as waste is not an obstruction to reuse or utilisation of the products if

- the material or its characteristics have a certain desired function

- the material fulfils certain criteria which are determined beforehand

- the material has a market value

- the material is not polluted to a degree that may cause environmental or health problems. 


\subsection{Sweden}

\subsubsection{Policy}

At present, Sweden does not have a specific policy on the establishment of EoW criteria as such. Various aspects of EoW, including the need for inclusion of information on total content in EoW criteria and the suitability of waste acceptance criteria (WAC) for landfilling of inert waste have, however, been considered by the Swedish Environmental Protection Agency (Strauss, 2010).

\subsubsection{Inclusion of information on total content in EoW criteria}

The Swedish Environmental Protection Agency (Naturvårdsverket) is of the opinion that a requirement for total composition is necessary for the EoW criteria for aggregates. A leaching test will not give all necessary information for assessing the risk of utilising the waste. A content of substances of very high concern (SVHC) may impose a risk even if the substances are not mobile in a leaching test. Direct exposure, oral intake and spreading with dust are examples of risks that are not fully taken into account by a leaching test and are scenarios that will need to be considered.

Substantial efforts are spent phasing out SVHC in products. The same approach should be applied to waste that ceases to be waste. Naturvårdsverket points out that testing for total composition is necessary for that reason alone.

The use of waste containing SVHC, but exhibiting insignificant leaching, may in the long term still cause a diffuse spreading of pollutants. The diffuse spreading of metals and organic substances may affect the natural background levels of these substances in soils.

Naturvårdsverket further points out that the knowledge about total content of SVHC in a waste/product most likely will be necessary for registration according to REACH. This further underlines the need for this information. 


\subsubsection{The use of WAC for landfilling inert waste}

Naturvårdsverket is of the opinion that using the waste acceptance criteria (WAC) for landfilling of inert waste as a limit value for EOW criteria is not appropriate. The WAC for landfilling of waste is primarily developed for protection of groundwater based on drinking water criteria in a defined landfill scenario. This is not sufficient to serve as a means of general protection of the groundwater resources. The resulting effect on groundwater was accepted for specific locations for inert waste landfills where the site can be chosen. This is very different from accepting in principle that all groundwater can be impacted to that level.

Naturvårdsverket finds that the existence of a required geological barrier at inert waste landfills is a key factor in this context. The barrier means that the transport time for the leachate between the landfill and the ground water that should be protected is at least one year and that some retention of released substances takes place. Using the same scenario for EoW products, with a required geological barrier, will limit the potential use of these products. In practice this limitation is not suitable for most products. It is the opinion of Naturvardsverket that using the WAC for inert waste without the requirement of a geological barrier will provide insufficient protection of the groundwater quality. If the groundwater is polluted, the EoW criteria can be in conflict with the intentions of the Water Framework Directive.

Naturvårdsverket further points out that when deciding on the WAC for landfilling after the impact assessment modelling, there was a political negotiation that resulted in changed limit values. In most cases the limit values were set higher compared to the scientifically calculated values. The actual WAC in the Council Decision (2003/33/EC) is in the view of Naturvårdsverket not only based on a scientific calculation, but also on a political negotiation.

\subsubsection{Specific conditions}

Naturvårdsverket is concerned if it is necessary to set specific conditions for using the EoW material. The need for conditions could indicate that the material still should be considered as waste. It is the opinion of Naturvårdsverket that the waste that ceases to be waste should not entail any environmental problems and conditions should not be necessary. 


\title{
4. Status of the use of C\&D waste and other aggregates in the Nordic countries
}

\begin{abstract}
Section 4.1 in this chapter briefly presents the situation in each of the Nordic countries with regards to the amounts and types of C\&D waste produced and recycled/used and the environmental/health legislation (if any) that regulates the use of these waste materials (and other waste aggregates). Rather detailed statistics are available for C\&D waste in Denmark and Finland, whereas the statistics from Norway, Sweden and the Faroe Islands are less complete. No information has been received from Iceland. More comprehensive information on the situation in each of the Nordic countries can be found in Appendices 1 through 5. Functional criteria for use of C\&D waste as aggregates are briefly addressed in section 4.2 , and some relevant studies and initiatives concerning C\&D waste are listed in section 4.3. In section 4.4 the substances that have been identified as problematic in relation to management and use of C\&D waste in the Nordic countries are summarised.
\end{abstract}

\subsection{Amounts, recycling and regulation of C\&D waste and other aggregates}

In Denmark, approximately 6 million tonnes of C\&D waste are recycled annually, including approximately 1.5 million tonnes of concrete. The use of C\&D waste for construction purposes is regulated by Statutory Order no. 1662/2010 on recycling of residual products and soil in building and construction work and on recycling of sorted, unpolluted C\&D waste. Residual products (currently MSWI bottom ash, coal fly ash and coal bottom ash) must fulfil criteria on content of TOC and inorganic substances and on leaching of a number of inorganic substances (using EN 12457-1) to be placed in three categories ranging from free use to increasingly more restricted use in applications such as sub base in roads. If the leaching exceeds criteria for category 3 , recycling requires special permission or the residues must be landfilled. The use of $C \& D$ waste requires that the waste 
is sorted into the fractions natural stones, non-glazed tiles, concrete, mixtures of stone materials, non-glazed tiles and concrete, iron and metal, gypsum, stone-wool and soil. It also requires that the C\&D waste is "uncontaminated", but currently there are no criteria on content or leaching for C\&D waste. In Statutory Order no. 1662 of 21 December 2010, uncontaminated C\&D waste is defined as C\&D waste for which it with a high degree of certainty can be assumed that the waste does not contain polluting materials or substances to such an extent or of such a nature and concentration that the use of the waste may have an adverse impact on the environment or human health. The waste must hence not contain polluting substances, including substances that can cause contaminating release to soil or groundwater, including e.g. impregnated wood, PCB containing sealants, tar, soot, remains of paint and lacquer. The recycling of asphalt is dealt with by other legislation. C\&D waste has been identified as a high priority waste stream in the Danish government's current waste management strategy (Danish EPA, 2010a) as well as in the coming resource strategy for the future. Several initiatives have been taken to improve the management and quality of C\&D waste, and special attention is being paid to problems associated with PCB (see Appendix 1).

In the Faroe Islands, a substantial amount of the C\&D waste produced is landfilled and only smaller amounts are recycled. There are no testing requirements on C\&D waste to be recycled.

Approximately 25 million tonnes of mineral C\&D waste are produced annually in Finland, and a substantial amount of this is recycled for construction purposes. The Finnish decree on reuse of some waste materials in earth construction (Government Decree 591/2006) regulates the recycling of crushed concrete as well as fly ashes and bottom ash from combustion of coal, peat and wood-based materials. The Decree sets limit values for content of PCB, PAH, hydrocarbons and some trace elements and for leaching of several inorganic substances (almost corresponding to the substances to be tested for acceptance at European landfills). The required test methods are CEN/TS 14405 (basic characterisation) and EN 12457-3 (compliance). The applications in which the crushed concrete is used must be covered or paved.

In Norway the recycling of C\&D waste, which is substantial, is not directly regulated by specific requirements or criteria, but a number of guidelines and standards related to road construction are available. Many Norwegian projects have been carried out to investigate in particular the content of substances of concern, in particular PCB, in demolition waste, and to find the origins of these pollutants that are found e.g. in a substantial proportion of the waste concrete. 
At present, there are no reliable statistics on the amount of recycled aggregates, including C\&D waste in Sweden, but it appears to be of the order of 1 to 3 million tonnes per year. The amount of crushed concrete recycled appears to be approximately 1 million tonnes per year. About $90 \%$ is used in unbound applications. The use of waste for construction purposes is an environmentally hazardous activity under the Ordinance on Environmentally Hazardous Activities and Public Health (SFS 1998:899). Depending on the risk, the activity must be notified to the municipal council or licensed by the county administrative board.

A special issue across the Nordic countries: So far, there seems to have been major differences in the way criteria on the content of PCB in waste, including $\mathrm{C} \& \mathrm{D}$ waste, are interpreted. From the information provided, it seems that measurements of PCB to be compared to limit values, e.g. the value of $50 \mathrm{mg} / \mathrm{kg}$ which is the EU limit that will render a waste hazardous due to its content of PCB, in Norway and Sweden is the sum of 7 specified congeners, whereas in Denmark, the sum of the 7 congeners is multiplied by 5 prior to comparison with the limit value. The uncertainty about the interpretation of "PCB" originates from the Council Regulation $1272 / 2008$ on classification, labeling and packing of substances and mixtures (and its predecessors) where the substances are presented merely as PCB although it consists of 209 different compounds. No explanation or help is offered in the regulation. However, as part of the on-going revision of Decision 2000/352/EC on the list of waste, the Commission has proposed that the PCB content shall be measured as the sum of the (7) PCB congeners 28, 52,101, 118, 138, 153, 180 multiplied by a factor 5 for a general estimation of the total PCB content, considering non-analysed congeners. This should end the confusion.

\subsection{Functional criteria}

Each of the Nordic countries has their own functional specifications for C\&D waste aggregates to be used for various construction purposes. However, most of the functional, physical specifications can be found in the harmonised European product standards on aggregates, which have been developed by CEN/TC 154: Aggregates:

- EN 13285: Unbound mixtures - Specifications.

- EN 13286: Unbound and hydraulically bound mixtures - Test methods. 
- EN 13242: Aggregates for unbound and hydraulically bound materials for use in civil engineering work and road construction.

- EN 13043: Aggregates for bituminous mixtures and surface treatments for roads, airfields and other trafficked areas.

- EN 13620: Aggregates for concrete.

These standards apply to all types of aggregates whether they are primary raw materials, recycled waste (C\&D) aggregates or waste-derived C\&D aggregates with EoW status.

\subsection{Relevant studies and data regarding environmental and health related properties of C\&D waste}

Safe management and recycling/use of C\&D waste have very high priority in both Denmark, Finland, Norway and Sweden, and several studies and initiatives have been or are being carried out in support of these goals. Some of these studies are briefly highlighted below.

A Danish study (Miljøstyrelsen, 2003) has provided information on the content and leaching properties of several C\&D waste fractions, including crushed concrete. The substances considered included chloride, sulphate, several trace elements, BTEX, hydrocarbons, PAH and PCB. The results showed that crushed concrete exceeded the most stringent leaching criteria (Category 1 and 2) for $\mathrm{Cr}$ and $\mathrm{Ba}$ for utilisation of residual waste materials (Statutory Order no. 1662/2010).

The Danish waste management strategy aims to improve the quality of the recycling of $C \& D$ waste and to ensure that the content in and release of harmful substances, in particular PCB, from recycled C\&D waste are low and does not exceed acceptable levels. Efforts are planned to assess the feasibility of setting criteria for the content and leaching properties of C\&D waste to be recycled, to point out which materials are likely to contain PCB, and to ensure that PCB-containing C\&D waste is managed correctly. Four projects have been initiated in order to ensure that as much as possible of the PCB-containing waste already during the demolition and renovation phase can be separated from the C\&D waste that is processed to be recycled. The objective of the first of these projects is to develop a general limit value for PCB in C\&D waste that is low enough to ensure that the waste can be considered unpolluted by PCB and hence suited for recycling. The second project is aimed at the collection of information and development of guidance on how to recognise materials that 
may contain PCB during renovation and demolition and thereby facilitating removal and correct handling of PCB-containing waste. It is also an objective to collect existing knowledge on the spreading of PCB from joints into the concrete in preparation of a guideline on removal of concrete contaminated with PCB. The third project shall establish a formalised, coordinated inventory and registration system in connection with renovation and demolition of certain buildings. This will ensure that builders and contractors identify the presence of PCB in a building and that the regulatory requirements on occupational health and waste management can be fulfilled. A fourth initiative will be taken to carry out stakeholder discussions of educational requirements and certification in order to ensure that selective demolition of larger buildings can be carried out properly. In addition to this, a study has been initiated to describe the content and release of dangerous substances from two types of C\&D waste, crushed concrete and tiles, in preparation of the development of quality criteria for C\&D waste to be recycled.

In Finland, a project on advanced material technology for infrastructure building has been carried out to increase the use of recycled materials and by-products and to decrease the use of natural resources. The Finnish Ministry of the Environment has carried out the following projects and activities:

- Production of a report (2010) highlighting the legislative boundaries, approach for evaluation of environmental acceptability of by-products in earth construction and analysis of some candidate waste streams for EoW-concept.

- Hosting an International seminar: END OF WASTE FOR MINERAL RESIDUES - aspects of concern in earth construction, 25th November 2008. The objective of the seminar was to address issues on using recycled materials and by-products as aggregates in earth constructions. The seminar provided different European legislative perspectives and practices and a forum for the exchange of information. The target group included different operators from manufacturers to contractors, regulators, scientists and other professionals.

- Performance of material-specific workshops with invited stakeholders - identification of knowledge gaps and legal barriers for use. 
In March 2010 a Norwegian study with the aim of mapping new fractions of hazardous waste in C\&D waste was completed (Norconsult, 2010). The main results from the project were:

- It is likely that hard polyurethane produced up until 2003 contains $\mathrm{CFC} / \mathrm{HCFC}$ gases. This material is found in garage doors, prefabricated walls for refrigeration rooms and prefabricated insulated outer walls, for example in pre-fabricated warehouses.

- Vinyl flooring may contain a number of environmental contaminants, such as phthalates, asbestos, lead and, in some cases PCB. In most cases flooring produced after 2000 is not hazardous waste.

- Skirting boards of PVC almost always contain a measurable of phthalates and above the limit for hazardous waste. Vinyl flooring from both demolition and rehabilitation is often treated as residual waste today. Flooring should first be analysed and, if found to contain phthalates, disposed of accordingly.

- Roofing, folding walls and chair seats of soft PVC-sheets produced before 2000 may also contain hazardous waste levels of phthalates and lead.

- Double-glazed windows produced after the "PCB period" may contain relatively large quantities of chlorinated paraffins, chiefly in the glue and the rubber mouldings. The production period from 1975 to 1990 appears to the period with largest the proportion of double-glazed windows containing chlorinated paraffins.

- Insulation of cellular rubber produced before 2004 is often a hazardous waste because of brominated flame retardants' levels. It may also contain other environmentally dangerous substances.

- Cable housings of plastic may contain quantities of lead above the limit of hazardous waste.

The Swedish EPA provides guidance to supervisory authorities on waste recycling in construction works and may in some cases take part in the permitting process. The Swedish EPA has recently published guidance in a handbook for utilisation of waste in construction works (Naturvårdsverket, 2010). The handbook gives guidance on utilisation of waste as construction material in a safe manner for environment and human health. Legislation that applies for utilisation of waste as construction material and the relation to the national environmental objectives is described. The handbook provides guidance for the supervision authorities when handling notifications and applications for waste utilisation and it 
describes necessary information for the assessment. The handbook also provides guidance on what can be considered as a pollution risk that is less than minor when it comes to waste recycling in construction works. Pollution levels for "less than minor risk" are presented in the handbook - when there are no restrictions for use and that no notification to the municipal board is necessary. Levels are also presented for utilisation when the waste is used in the top cover of a landfill. Levels are presented for content as well as leaching properties for 13 substances that are often the most critical ones in waste. Guideline for "less than minor risk" values are strict (based on natural background values for some phase-out substances) so that the use does not result in new contaminated sites or that contaminants are leaching where it cannot be controlled in the future Swedish EPA has accounted for these guideline values as an input to "end of waste" criteria in the Austrian Aggregates Case Study (Böhmer et al., 2008). These guideline values do not apply to bound materials e.g. asphalt pavements.

\subsection{Substances of environmental and health concern}

Some time ago (in 2006), the Danish EPA has supported a project which identified a list of 12 particularly problematic substances in C\&D waste and their origin. They are: $\mathrm{Cd}, \mathrm{Cr}, \mathrm{Cu}, \mathrm{Hg}, \mathrm{Ni}, \mathrm{Pb}, \mathrm{Zn}, \mathrm{PCBs}$, chloroparafins, chlorofluorocarbons (CFC), hydrochlorofluorocarbons (HCFC) and hydrofluorocarbons (HFC), and sulphurhexafluoride (SF6).

Finland has identified the following harmful substances in mineral demolition waste: Organically bound $\mathrm{Cd}$, metallic $\mathrm{Cd}$, metallic $\mathrm{Hg}$, metallic $\mathrm{Pb}$, organic $\mathrm{Pb}, \mathrm{PCB}$ compounds, $\mathrm{CFC}$ compounds oil and $\mathrm{PAH}, \mathrm{Cr}$ and $\mathrm{Mo}, \mathrm{Cu}$ and phenolic compounds. The origin of these substances has also been assessed.

The Norwegian study mentioned in section 4.3 have focused on PCBs, phtalates, brominated flame retardants, chloroparaffins, CFC and $\mathrm{HCFC}$ and $\mathrm{As}, \mathrm{Cd}, \mathrm{Hg}, \mathrm{Pb}$ and $\mathrm{Sb}$ and on the origins and presence of these substances.

It is evident that it is basically the same substances that are considered critical in all three countries. They should all be included in the testing/analysis programme if EoW criteria for C\&D waste will be developed. 



\title{
5. Methodology for development of EoW criteria for C\&D waste in the Nordic countries with particular focus on leaching
}

\author{
5.1 Potential impacts on the environment and \\ human health resulting from use of C\&D waste \\ with EoW status
}

\subsubsection{Potential impacts and pathways}

In this context, the main concern in relation to the possible use of C\&D waste aggregates with EoW status is the potential risk that the materials may contain substances that can cause unacceptable impacts on soil, surface water or groundwater and/or on human health. This concern is expressed in condition (d) in Article 6 (1) of the WFD: "The use of the substance or object will not lead to overall adverse environmental or human health impacts" and to the associated condition that "The criteria shall include limit values for pollutants where necessary and shall take into account any possible adverse environmental effects of the substance or object".

In section 4 it was shown that the both the "raw" and the processed C\&D waste may contain both organic and inorganic pollutants that may cause unacceptable impacts if released to the environment or brought into contact with humans. For crushed concrete, for example, such substances may be incorporated as part of the concrete itself, they may be present as part of paint on the original surface of the concrete or as pollutants that has migrated from the surface into the concrete, or they may constitute parts of non-concrete impurities present in the crushed concrete aggregate product. The nature of the pollutants will to a large extent 
determine the method by which they can be voided in or removed from the aggregate product.

Figure 1 illustrates the various human health risks and environmental risks that could be associated with different pathways and different receptors (humans, soil, groundwater, surface water) when C\&D waste aggregates are used for construction purposes (Naturvårdsverket, 2010).

Figure 1: Illustration of the types of risk assessments used in the setting of criteria for use of waste materials for construction purposes in Sweden Health risks

Environmetal risks

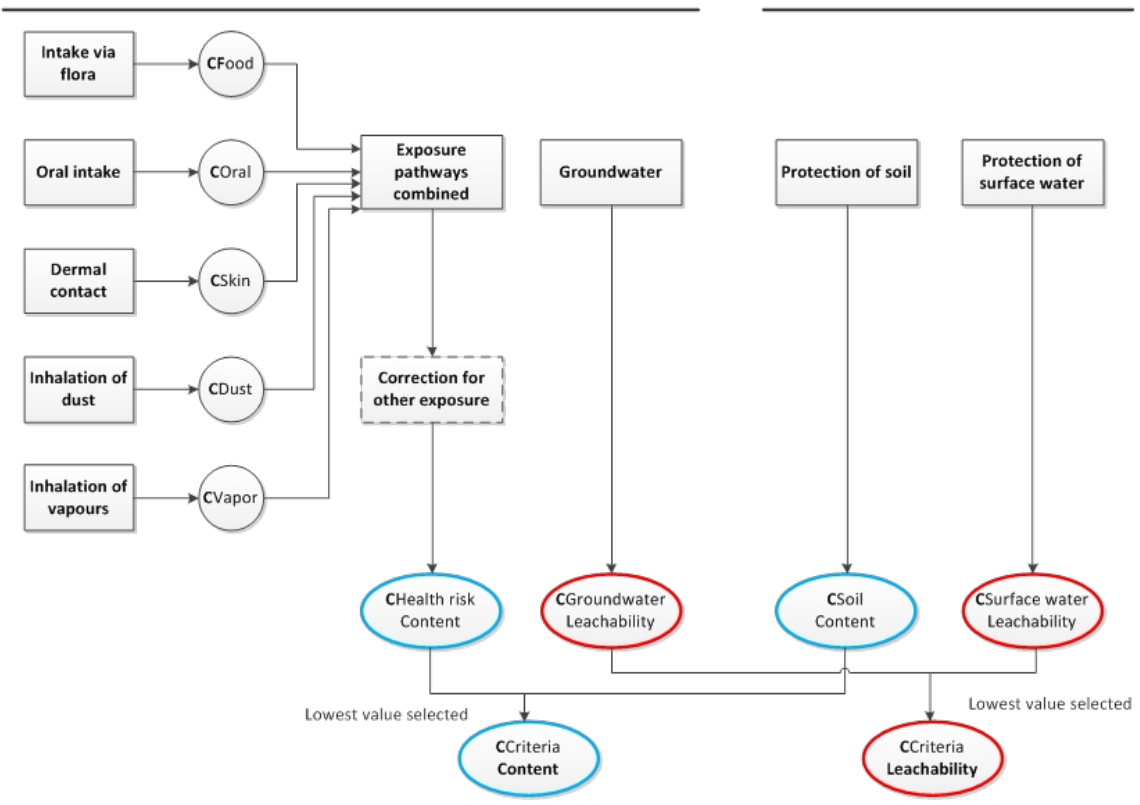

Source: Naturvårdsverket, 2010.

As indicated in Figure 1, which is equally valid for waste materials and products (virgin or waste-derived), the assessment of the potential pollution from C\&D waste aggregates used in construction works and the possible development of EoW criteria should be based on determination of both total content and the leaching properties of substances in the C\&D aggregate in question depending on the pathway and the receptor under consideration. 


\subsubsection{Conceptual impact assessment model}

The risks or impacts posed to the environment or human health by C\&D waste with EoW status (and other natural, secondary or recycled aggregates) used in construction works can be conceptually described as a chain of events, see Figure 2. This chain represents a well-established principle in environmental risk assessment and consists of the identified potential contamination source(s) and receptor(s) as well as the potential migration pathways between them. A risk or an impact only arises if the chain remains unbroken and there is a negative effect at the receptor. The conceptualisation of risk/impact assessment as a chain can be seen as a descriptive tool and will be used as such in this context. From a systematic perspective it seems useful to consider each part of the chain separately as the basis for impact assessment scenarios and the associated models.

Figure 2: The concept of risk/impact illustrated as a chain of events. For a risk or impact to occur, the chain must remain unbroken, and an undesired effect must occur at the receptor

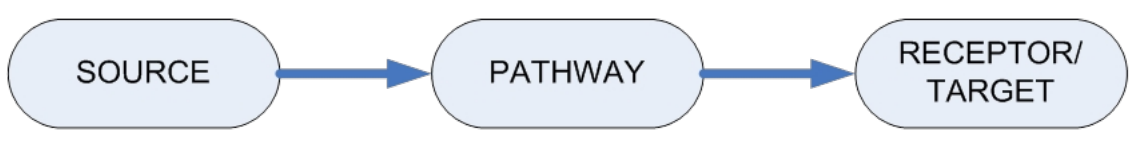

In this context, the main emphasis will be on evaluation of relevant combinations of sources, pathways and receptors associated with the release of substances from aggregate applications by leaching, direct contact with or transport through soil and aquifers or surface water bodies to points of evaluation or compliance in soil, surface water or groundwater (primary receptor). The actual or final receptor will be the humans or the ecosystem that by use of or contact with the primary receptor are affected by the impact. The relevant quality criteria to be set and complied with at the primary receptor are reflected by and should be based on existing EU or national legislation on groundwater, surface water and soil quality.

Exposure routes such as inhalation (e.g. of dust), ingestion, direct (dermal) contact and occupational exposure (see Figure 1) are not addressed in detail in this study. They are as important as the exposure routes related to leaching, but it is assumed that existing national legislation on maximum content of (dangerous) substances in materials (e.g. waste and soil) that can be used freely without restrictions or under conditions preventing direct contact sufficiently reflect and protect against the risks associated with these exposure routes and could be applied as part of new EoW criteria in addition to leaching criteria. 
The conceptual model described above will be relevant in relation to any use of secondary or recycled aggregates regulated under waste legislation in construction works as well as for the use of C\&D waste (and other aggregates) that have obtained EoW status.

In the following, the source, pathway and receptor concepts and their application to the development of EoW criteria aimed at the protection of the environment and human health will be discussed separately. The description of the source, pathway and receptor will be focused on the potential risks to the environment associated with release (leaching) of substances. Health risk issues and limit values on total content are addressed briefly in section 5.1.4.

\subsubsection{Impacts on and protection of soil, groundwater and surface water}

\section{Potential impacts}

For assessment of the potential impact on soil, groundwater and surface water from dissolution and transport of substances from C\&D wastebased aggregate used in a construction project, determination of the leaching properties of the material in question will be relevant. There is seldom a direct relationship between the content of a substance in an aggregate and the leaching behaviour of that substance. One reason for this is that elements may be incorporated into the aggregate matrix and may not become accessible upon contact with water. Another reason is that solubility limitations by minerals and sorption processes may prevent the elements for leaching at levels proportional to their content. The fraction of a substance that is available for leaching may thus be a very minor portion of its total content, even under more extreme conditions (acidic conditions and material size-reduced to fine granular particulates). For substances for which no reliable leaching tests exist or for which the performance of a leaching test is impossible, assessments made on content may be necessary. This is in particular the case for organic substances. In general, content is a poor indicator of the potential risk of an impact on the environment (soil, groundwater, surface water), while the leaching properties of an aggregate are directly related to these types of impacts.

C\&D waste, including crushed concrete, may contain leachable amounts of salts (e.g. sulphates from materials contaminated with gypsum from plasterboards) and trace elements/heavy metals (e.g. $\mathrm{Cr}, \mathrm{Cu}, \mathrm{Ni}$ and others), see chapter 4 and the associated appendices. Depending on the amounts released, the conditions under which the C\&D waste is used, 
and on the pathway and distance to the receptor, some of these substances may pose a risk to soil, groundwater and surface water. When released from the C\&D waste by leaching, some of the substances (e.g. the salts (chlorides and sulphates) and few trace elements such as $\mathrm{Sb}$ and $\mathrm{Se}$ ) are relatively mobile in soil and groundwater, and will reach the receptor fairly quickly, while others such as e.g. $\mathrm{Ba}, \mathrm{Cd}, \mathrm{Cr}, \mathrm{Zn}$ are less mobile and migrate more slowly through soil and groundwater. Some trace elements/heavy metals (e.g. $\mathrm{Cu}$ and $\mathrm{Pb}$ ) have very low mobilities and will accumulate in the unsaturated zone below the C\&D waste and migrate very slowly through soil and groundwater towards a receptor. Depending on the conditions, it may take several hundreds to thousands of years for some substances to reach a receptor even though they may be released over a much shorter period of time. Most of the organic substances of concern that may be leached from $C \& D$ waste are likely to have a relatively low mobility in the subsoil environment. If the C\&D waste is placed in direct contact with groundwater or surface water, the substances are released from the source directly into the receptor without the mitigating effect of retention along the pathway, and the impact is instant for all substances and generally more substantial.

\section{Specific Nordic aspects and concerns}

The Nordic countries have a special interest in protecting the quality of groundwater and surface water. In Denmark, almost all of the drinking water is extracted from groundwater and generally used without treatment (except aeration and filtration), and protection of the groundwater from contamination therefore has high priority. The groundwater quality is already threatened by increasing diffuse contamination of surface soil and from the use of pesticides and fertilisers. It is therefore important to control and limit new potential sources of contamination of the groundwater. In Finland, Norway and Sweden much of the drinking water comes from lakes which support fragile ecosystems that are vulnerable to contamination with both inorganic and organic substances, and protection of the surface water quality therefore has particular high priority in these countries. Another specific Nordic aspect is the relatively high level of precipitation in the region which can lead to a high degree of leaching of aggregates used for construction purposes. The low temperatures that occur during the winter in large parts of the Nordic region may also lead to a relatively high degree of disintegration due to freeze/thaw cycles and result in increased exposure of C\&D waste used in bound applications, e.g. as aggregate in concrete. If and when criteria shall be set for the use of C\&D waste and other aggregates as waste materials or as products with EoW status, these issues must be taken into account. 


\section{Primary water quality criteria}

When performing assessments of the risk of contaminating groundwater and surface water and setting limit values for leaching in accordance with the conceptual model shown in section 5.1.2, the primary criterion is that the desired quality of the receptor (at the "point of compliance", POC) shall not be exceeded as a result of the impact caused in this case by $C \& D$ waste used in a construction project. For a given substance such a criterion could be the maximum acceptable concentration of the substance in the groundwater or surface water at the POC. This primary water quality criterion is totally independent of the nature of the source, and in principle also of the pathway.

In the development of the EU leaching criteria for acceptance of waste at e.g. inert waste landfills, the POC was the groundwater at a distance of $20 \mathrm{~m}$ or, for some soluble and mobile substances, $200 \mathrm{~m}$ downstream of the landfill (Hjelmar et al., 2001) where the concentrations of various substances must not exceed certain values (the primary quality criteria). In general, this means that these primary criteria will be exceeded in the groundwater between the landfill and the POC, and this groundwater is more or less "written off", i.e. it is accepted that it may have a lower quality, whereas the groundwater downstream of the POC will not exceed the primary quality criteria. In some countries (e.g. Germany) using risk assessment scenario-based modelling to set criteria for use of recycled aggregates, the POC is placed at the interface between the unsaturated zone and aquifer directly below the application, thus not allowing for attenuation/dilution in the aquifer. In this case no groundwater is "written off". If the receptor is a surface water body and the groundwater-based POC is located at the upstream boundary of the water body but downstream of the source, the water in the surface water body will not exceed the primary quality criteria set at the POC at any place, at least not because of the source in question. However, if the POC is located somewhere offshore or (for a river) downstream, and part of the surface water body constitutes the last part of the pathway, and dilution in the surface water body is required to comply with the quality criteria at the POC, then part of the surface water body (between the point of entry of the pathway into the surface water body and the POC) may also exhibit concentration levels of the substances in question that exceed the primary quality criteria.

For the development of leaching limit values in the context of assessing EoW criteria for aggregates at EU level, it would be useful to apply EU-wide groundwater or surface water quality criteria as primary quality criteria. Unfortunately, such criteria do not exist. Instead one could use the EU drinking water criteria (Directive 98/83/EC) although it should be 
remembered that they are meant to protect human consumers of water, not the ecosystem which may be more vulnerable to certain substances than humans are.

During the development of the EU leaching criteria for acceptance of waste at landfills, slightly modified criteria based on the WHO guideline for drinking water quality were used as primary groundwater quality criteria (Hjelmar et al., 2005). It would also be appropriate to adopt the national groundwater quality criteria from a country relying heavily on good quality groundwater as the source of drinking water. Similarly, relatively stringent national surface water quality criteria could be applied as primary quality criteria for surface water bodies. Table 2 shows some examples of water quality criteria for mainly inorganic substances that might be relevant in the context of the development of EoW criteria for aggregates.

With very few exceptions (DOC and phenols), the leaching based waste acceptance criteria (WAC) for landfilling only include inorganic substances. The main reason for this is that whereas there are standardised and well proven leaching tests for inorganic substances at EU level, leaching tests for organic substances are much less developed, and at present, the experience with leaching tests for organic substances is probably not sufficient for them to be applied in general to regulatory systems. As a substitute, the total content of organic substances of concern should be determined as the basis for an assessment. Typically, processed C\&D waste will only contain traces of organic substances, and many of these, e.g. polycyclic aromatic hydrocarbons (PAHs) and polychlorinated biphenyls (PCBs), are, as mentioned above, relatively immobile in soil and groundwater. The transport may, however, be facilitated by the presence of dissolved organic carbon DOC in the leachate from the aggregates. Since DOC can also enhance the mobility of inorganic substances (e.g. $\mathrm{Cu}$ ), there is good reason to set limits on the release of DOC from aggregates when assessing EoW criteria. 
Table 2: Examples of primary water quality criteria

\begin{tabular}{|c|c|c|c|c|c|c|c|}
\hline \multirow[t]{3}{*}{ Substance } & \multirow{3}{*}{$\begin{array}{r}\text { EU DWQC } \\
\mathrm{mg} / \mathrm{l}\end{array}$} & \multirow{3}{*}{$\begin{array}{l}\text { GWQC EU LFD } \\
\text { mg/l }\end{array}$} & \multirow{3}{*}{$\begin{array}{r}\text { GWQC DK LF } \\
\mathrm{mg} / \mathrm{l}\end{array}$} & \multicolumn{2}{|c|}{ Surface WQC DK } & \multicolumn{2}{|c|}{ Swedish WQC } \\
\hline & & & & Fresh water & Marine & Groundwater & Surface water \\
\hline & & & & $\mathrm{mg} / \mathrm{l}$ & $\mathrm{mg} / \mathrm{l}$ & $\mathrm{mg} / \mathrm{l}$ & $\mathrm{mg} / \mathrm{l}$ \\
\hline Bromide & 0.010 & & & & & & \\
\hline Chloride & 250 & 250 & 150 & & & 50 & 15 \\
\hline Fluoride & 1.5 & 1.5 & 1.5 & & & & \\
\hline Sulphate & 250 & 250 & 250 & & & 50 & 30 \\
\hline $\mathrm{NH}_{4}-\mathrm{N}$ & 0.50 & & & & & & \\
\hline Nitrate & 50 & & & & & & \\
\hline Nitrite & 0.5 & & & & & & \\
\hline Cyanide & 50 & & & & & & \\
\hline $\mathrm{Na}$ & 200 & & & & & & \\
\hline Al & 0.20 & & & & & & \\
\hline As & 0.010 & 0.010 & 0.008 & 0.0043 & 0.00011 & 0.003 & 0.0003 \\
\hline $\mathrm{Ba}$ & & 0.70 & 0.70 & 0.0093 & 0.0058 & & \\
\hline $\mathrm{Cd}$ & 0.0050 & 0.0040 & 0.0020 & $0.00008-0.00025$ & 0.0002 & 0.0015 & 0.00002 \\
\hline Co & & & & 0.00028 & 0.00028 & & \\
\hline $\mathrm{Cr}$ (tot) & 0.050 & 0.050 & 0.020 & & & 0.015 & 0.0003 \\
\hline $\mathrm{Cr}(\mathrm{III})$ & & & & 0.0049 & 0.0034 & & \\
\hline $\mathrm{Cr}(\mathrm{VI})$ & & & & 0.0034 & 0.0034 & & \\
\hline $\mathrm{Cu}$ & 2.0 & 0.050 & 0.10 & 0.012 & 0.0029 & 0.050 & \\
\hline $\mathrm{Fe}$ & 0.20 & & & & & & \\
\hline $\mathrm{Hg}$ & 0.0010 & 0.001 & 0.001 & & & 0.0003 & 0.000005 \\
\hline $\mathrm{Mn}$ & 0.050 & & & 0.15 & 0.15 & & \\
\hline Mo & & 0.070 & 0.020 & 0.067 & 0.0067 & & \\
\hline $\mathrm{Ni}$ & 0.020 & 0.020 & 0.010 & 0.003 & 0.003 & 0.006 & 0.001 \\
\hline $\mathrm{Pb}$ & 0.010 & 0.010 & 0.0050 & 0.00034 & 0.00034 & 0.003 & \\
\hline $\mathrm{Sb}$ & 0.0050 & 0.0050 & 0.0020 & 0.113 & 0.0113 & & \\
\hline Se & 0.010 & 0.010 & 0.010 & $?$ & $?$ & & \\
\hline \multicolumn{8}{|l|}{ Sn } \\
\hline V & & & & 0.0236 & 0.0236 & & \\
\hline $\mathrm{Zn}$ & & 0.10 & 0.100 & $0.0031-0.0078$ & 0.0078 & 0.10 & 0.004 \\
\hline DOC & & 10 & 3.0 & & & & \\
\hline Phenol & & $0.10 *$ & 0.0005 & 0.0077 & 0.00077 & & \\
\hline
\end{tabular}

Note: * Phenol index.

EU DWQC: Drinking water criteria from EU Directive 98/83/EC on the quality of water intended for human consumption (not exhaustive).

GWQC EU LFD: Groundwater quality criteria used as primary quality criteria when developing the EU WAC for landfilling - based on WHO (1996) but slightly modified.

GWQC DK LF: Groundwater quality criteria used in the setting of Danish WAC for landfilling as part of implementing Directive 1999/31/EC and Council Decision 2003/33/EC (Hjelmar et al., 2005).

Surface WQC DK: Danish surface water quality criteria from Statutory Order No. 1022 of 25 August 2010 on environmental quality criteria for waters and criteria for discharge of contaminating substances to rivers, lakes and the sea (partly implementing Directive 2008/105/EC). Not exhaustive.

Swedish WQC: Primary groundwater and surface water criteria selected by the Swedish Environmental Protection Agency when developing criteria for unrestricted use of waste materials (Naturvårdsverket, 2010). 
The lists with water quality criteria referred to in Table 1 (EU Directive 98/83/EC and EU Directive 2008/105/EC as well as national regulation) also contains criteria for a large number of organic substances. They will not be shown here, since they cannot be directly related to the leaching properties of the aggregates through the risk or impact assessment procedure.

Since the purpose of the risk/impact assessment and the subsequent development of leaching criteria for aggregates to obtain EoW status in this case is to protect groundwater and surface water, the first step in the procedure should be to determine from which substance the water bodies should be protected (the primary quality criteria). This should be done on the basis of lists like those shown in Table 1. The next step would then be to find out to which extent these substances are present in and leached from the aggregates in question. On this basis an appropriate match between the primary quality criteria and the substances leached from the aggregates can be made, resulting in a list of substances for which the leachability criteria must be developed.

\subsubsection{Impacts on and protection of human health}

Determination of total content is relevant when determining the risk to human health by various pathways as shown in Figure 1. It may also be relevant when determining the risk to soil quality from the aggregate becoming mixed with soil. Analyses of total contents of both organic and inorganic substances can be compared directly to already existing limit values for use of waste materials and soil.

Table 3 shows some examples of limit values based on the content of various (inorganic and organic) substances in waste materials, soil and products that may be used, in some cases freely without restrictions. For comparison, EU limit values on the content of some organic substances in waste to be accepted at landfills for inert waste are also shown (Council Decision 33/2003/EC). 
Table 3: Various criteria for acceptance of inert waste for landfilling and use/free use of soil/waste materials in terms of content

\begin{tabular}{|c|c|c|c|c|c|c|c|}
\hline \multirow{2}{*}{ Substance } & A & B & C & D & E & $F$ & G \\
\hline & $\begin{array}{r}\text { LFD inert } \\
\mathrm{mg} / \mathrm{kg}\end{array}$ & $\begin{array}{r}\text { DK LF inert } \\
\mathrm{mg} / \mathrm{kg}\end{array}$ & $\begin{array}{r}\text { DK } \\
\mathrm{mg} / \mathrm{kg}\end{array}$ & $\begin{array}{r}\text { SE free use } \\
\mathrm{mg} / \mathrm{kg}\end{array}$ & $\begin{array}{r}\text { SE LF cover } \\
\mathrm{mg} / \mathrm{kg}\end{array}$ & $\begin{array}{r}\mathrm{Fl} \text { covered } \\
\mathrm{mg} / \mathrm{kg}\end{array}$ & $\begin{array}{r}\text { NO } \\
\mathrm{mg} / \mathrm{kg}\end{array}$ \\
\hline As & & & 20 & 10 & 10 & 50 & $<8$ \\
\hline $\mathrm{Ba}$ & & & $100^{2)}$ & & & & \\
\hline $\mathrm{Cd}$ & & & 0.5 & 0.2 & 1.5 & 10 & $<1.5$ \\
\hline $\mathrm{Cr}$ (total) & & & 500 & 40 & 80 & 400 & $<50$ \\
\hline $\mathrm{Cr}(\mathrm{VI})$ & & & 20 & & & & $<2$ \\
\hline $\mathrm{Cu}$ & & & 500 & 40 & 80 & 400 & $<100$ \\
\hline $\mathrm{Hg}$ & & & 1 & 0.1 & 1.8 & & $<1$ \\
\hline Mo & & & 52) & & & & \\
\hline $\mathrm{Ni}$ & & & 30 & 35 & 70 & & $<60$ \\
\hline $\mathrm{Pb}$ & & & 40 & 20 & 200 & 300 & $<60$ \\
\hline Se & & & $20^{21}$ & & & & \\
\hline $\mathrm{Zn}$ & & & 500 & 120 & 250 & 700 & $<200$ \\
\hline TOC & 30,000 & 30,000 & 30,000 & & & & \\
\hline BTEX & 6 & $6^{1)}$ & & & & & \\
\hline Benzene & & & & & & & $<0.01$ \\
\hline Toluene & & & & & & & $<0.3$ \\
\hline Ethylbenzen & & & & & & & $<0.2$ \\
\hline Xylene & & & & & & & $<0.2$ \\
\hline PCB (7 congeners) & 1 & 1 & $0.1^{4)}$ & & & 1 & $<0.01$ \\
\hline $\mathrm{PAH}$ & & 4 & $4^{2)}$ 3) & & & 20 & $<2$ \\
\hline Naphthalene & & 0.5 & & & & & $<0.8$ \\
\hline Benzo(a)pyrene & & & $0.3^{21}$ & & & & $<0.1$ \\
\hline DibenzO(a)anthracene & & & $0.3^{2)}$ & & & & \\
\hline Fluorene & & & & & & & $<0.8$ \\
\hline Fluoranthene & & & & & & & $<1$ \\
\hline Pyrene & & & & & & & $<1$ \\
\hline $\mathrm{PAH}$ low ring number & & & & 0.6 & 3 & & \\
\hline $\mathrm{PAH}$ medium ring number & & & & 2 & 10 & & \\
\hline $\mathrm{PAH}$ high ring number & & & & 0.5 & 2.5 & & \\
\hline Hydrocarbons (C10-C40) & 500 & & & & & 500 & \\
\hline Hydrocarbons (C6-C40) & & 150 & & & & & \\
\hline
\end{tabular}

Note: 1): Benzene max. $1.5 \mathrm{mg} / \mathrm{kg}$

2): Only for soil.

3) Sum of benz(a)pyrene, benzo(b+j+k)fluoranthene, dibenzo(a,h)anthracene, fluoranthene and indeno(1,2,3-cd)pyrene.

4) C\&D waste is considered unpolluted if the content of PCB is less than $0.1 \mathrm{mg} / \mathrm{kg}$ (7 congeners $\times 5$ ). The origins of the limit values for content shown in table 5.2 are presented in the following:

A: Criteria for acceptance of inert waste at a landfill for inert waste (EU Council Decision 2003/33/EC). The values are based on convention, not on a risk assessment.

B: Criteria for acceptance of inert waste at a Danish landfill for inert waste (implementation of the EU Council Decision in Denmark, Statutory order no. 719 of 24 June 2011 on landfilling of waste).

C: Criteria for use of contaminated soil or residual waste for specified purposes (unless there is suspicion of contamination by other contaminants than those shown), see Appendix 1 . The criteria on content are based on health considerations (contact, ingestion).

D and E: Criteria for free use (D) and use as landfill cover (E) of residual waste materials in Sweden - unless there is suspicion of contamination by other contaminants than those shown (Naturvårdsverket (2010): Återvinning av avfall i anlägningsarbeten. Handbok 2010:1, Stockholm. The criteria on content are based on considerations of the health risks associated with e.g. contact, ingestion and inhalation and on the risk of contamination of soil (see Figure 1).

F: Criteria for use of C\&D waste in a covered state (covered to prevent dust formation but not to reduce infiltration of precipitation) in Finland. Some of the criteria for content are similar to the EU WAC (PCBs and hydrocarbons), a limit value for $\mathrm{PAH}$ has been added together with limit values for content of a number of trace elements, based on toxicity considerations. It should be noted that the Finnish regulation does not allow the same degree of free use as B, C and D.

G: "Normverdier for forurenset grunn" in Norway, i.e. the concentrations at which the substances in question are considered not to constitute a risk to environment or health. Soil that fulfils these criteria is considered "clean" and may safely be used for all purposes (Statens Forurensningstilsyn: "Tilstandsklasser for forurenset grunn" (TA-2553/2009)). 


\subsection{Use without or with restrictions/conditions}

In relation to the development of environmental/health criteria for obtaining EoW status, two of the conditions in Article 6 (1) of the WFD are of particular interest:

- (a): "the substance or object is commonly used for specific purposes".

- (d): "the use of the substance or object will not lead to overall adverse environmental or human health impacts".

Further guidance may be found in the concluding sentence in Article 6 (1):

"The criteria shall include limit values for pollutants where necessary and shall take into account any possible adverse environmental effects of the substance or object"

The reference to "specific" purposes in (a) is repeated in (c) which addresses the fulfilment of the technical requirements for the "specific" purposes. It leads to the question of whether or not it is possible to restrict the use of a particular type of C\&D waste to certain "specific" purposes under certain specified conditions. Since the EU Commission has not (yet) provided a consolidated opinion on this, it seems useful to consider both situations, i.e. on the one hand the situation where a C\&D aggregate with EoW status can be used and traded freely without any restrictions, and on the other hand the situation where the same product can be used only for specific purposes under specified conditions. The two situations will lead to very different assessments of the potential environmental impacts and, as a consequence, to very different criteria and leaching limit values for achievement of EoW status.

If EoW criteria are developed for C\&D aggregates, they should in both cases ensure:

- A high degree of certainty that aggregates used under the EoW status actually fulfil the EoW criteria to be developed. This implies sufficient proof (e.g. in the form of a dossier) of absolute compliance with the criteria up front and effective subsequent quality control measures.

- That the generally acknowledged source-pathway-receptor scenarios upon which the EoW environmental and health protection criteria should be based should reflect the presence or absence of any restrictions or conditions on the use of waste derived aggregates with EoW status as well as the fact that their use in construction 
applications is without environmental criteria in most EU Member States have no legislation that regulates the potential environmental impact of construction products. This must be taken in account both in the source and pathway scenarios.

- That the source-pathway-receptor scenarios upon which the EoW environmental and health protection criteria should be based address not only the service life situation (i.e. the period during which the aggregate serves an intended and useful purpose) but rather the entire lifecycle, and in particular the end-of-life (EoL) situation (where the aggregate, if left unattended, may disintegrate and become exposed over a long time period to ambient conditions that may favour the release of potentially polluting substances) of the aggregates to be granted EoW status. This implies the inclusion of source term scenario(s) that reflect maximum and long term exposure conditions and includes the effects of potential chemical changes (e.g. carbonation of alkaline materials).

If no restrictions or conditions are placed on the use of waste-derived aggregates with EoW status, then the source term must account for the "worst case" release that may potentially take place. This would include testing of size reduced material both under initial conditions (first porewater composition) and under long term exposure conditions to determine the potential maximum release of substances.

An aggregate product which can be used and traded freely without restriction could in principle be end up anywhere, including in a heap in a sensitive lake. This is illustrated in Figure 3.

Figure 3: Scenario describing a worst case environmental impact scenario for waste derived C\&D material with EoW status without any restrictions on the use

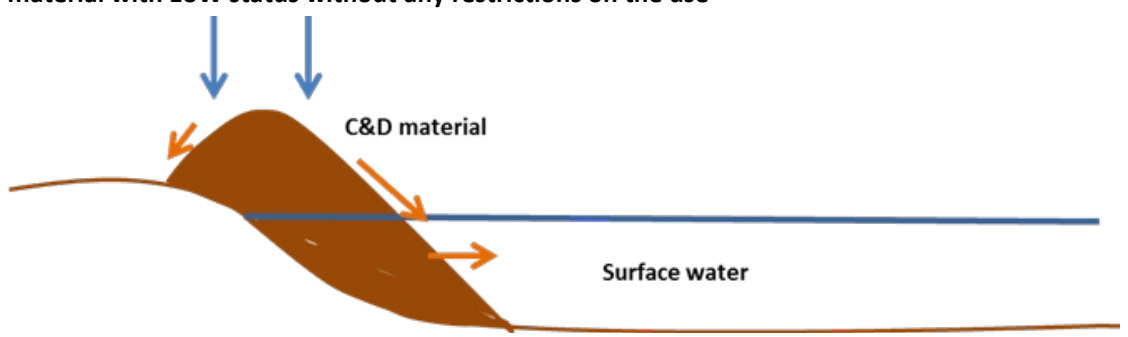


If, on the other hand, some restrictions and control measures were placed on the application of aggregates with EoW status, the scenario conditions used to assess the leaching results could be less severe without compromising the safety of the environment and human health. This is illustrated in Figure 4.

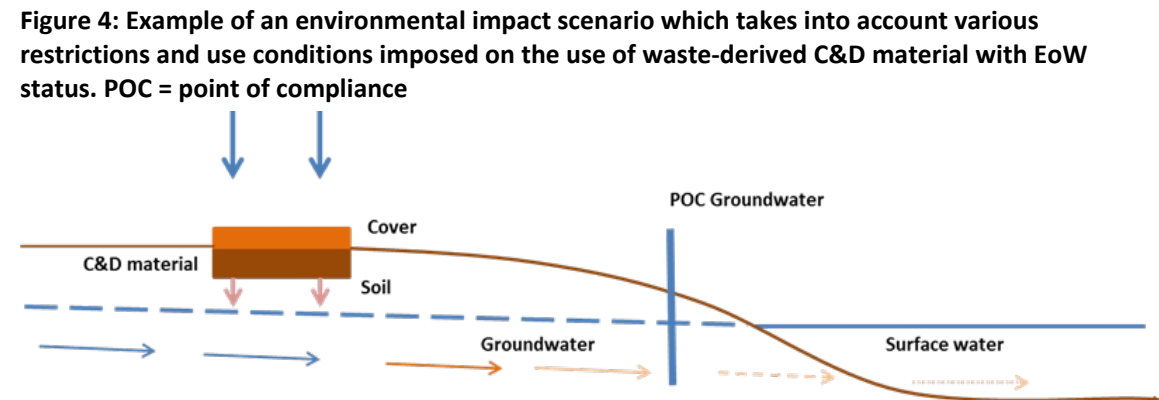

The heap of C\&D material placed in the lake as shown in Figure 3 (or in direct contact with the groundwater) should perhaps be characterised as a mismanagement scenario rather than a use scenario, but it does represent a risk that should be taken into account, if no restrictions are placed on the use of C\&D waste-based aggregate with EoW status which is placed on the market. Section 5.3 provides an example of how leaching based EoW criteria could be developed to account for this situation and how limit values could be calculated.

Figure 4 shows some of aspects of normal use scenarios for aggregates and waste aggregates where top covers may reduce the rate of infiltration and attenuation of released contaminating substances may be attenuated in the unsaturated and saturated zones before reaching the point of compliance which may be downstream groundwater or surface water. In the Nordic countries typical uses of virgin and waste-derived aggregates which will also be relevant for C\&D waste, particularly crushed concrete, with EoW status, are:

- Unbound use in base and sub-base layers under roads and parking lots.

- Unbound use as sub-base in highway ramps and embankments.

- Unbound use as filling material in noise reduction barriers.

- Unbound use as filling material under buildings.

- As aggregates in hydraulically bound applications (concrete). 
The entire life-cycle of the material in the application should be taken into account, and the source term scenario must reflect this in terms of maximum potential release of substances. Based on experimental evidence it seems safe to assume that the leaching of most substances from an intact bound material will be less extensive than the leaching of the same substance from the same material in a crushed or crumbled state. Since a bound material (and a coarse unbound material) may eventually end up in a crumbled stage with small particle size in the end-of-life (EoL) stage, aggregates used in bound applications should be tested in that crumbled state, and the source term scenario(s) for these materials should be based on this and include the potential effects of ageing, carbonation and changes in $\mathrm{pH}$ and redox potential. This means that the same physical source term scenarios can be used to describe the release of substances from both bound and unbound conditions.

For a given (chosen) source term scenario, the source term should describe the release of relevant substances as a function of time over the relevant timeframe in terms of quantity and quality of the leachate, i.e. the amount of leachate and the concentration of the substances in the leachate. If conditions are set for the use of the aggregate with EoW status, the effect of these conditions should be reflected in the scenario and the source term. This information would also provide the flux of released substances as a function of time. The source term description for a given aggregate will generally be based a combination of leaching test results, assumed scenario conditions and modelling. The pathway/transport scenarios will form the basis for modelling of the transport of substances from the application to the primary receptor using the output from the source term assessment e.g. in terms of amounts of substances and leachate as a function of time as input.

Section 5.4 provides an overview of some use conditions that can be included in the setting of EoW criteria for waste-derived aggregates and that will reduce the impact on the environment.

Section 5.5 provides a description of a methodology for development of leaching limit values for achievement of EoW status for waste derived aggregates that could be used under Nordic (or European) conditions. In section 5.7 some examples of application of the methodology on different use scenarios are presented. 


\subsection{EoW criteria without restrictions or conditions on the use}

\subsubsection{The source term}

If no restrictions are placed on the uses of waste-derived aggregates which have obtained EoW status, the environmental and health criteria to be fulfilled must take this into account, i.e. must be based on relatively conservative (if not worst case) application scenarios. In order to take "any (potential) adverse environmental effects" into account, the entire life cycle of the product, including the End-of-Life (EoL) situation, should be taken into consideration. This approach will probably differ most from the in-use situation for aggregates used in bound applications. The release of substances from bound materials during the service life, when they are fully or nearly intact, will probably be small (and hence not restrictive with respect to potential environmental impact) compared to the potential release of substances when the products disintegrate/crumble sometime in the future. When that happens, the products may be anywhere in the environment if the use is uncontrolled and unrestricted. This means that the critical release of substances from bound use of waste-derived aggregates to be compared to appropriate limit values should be determined on size reduced material under conditions that represent an initial release and/or a long term exposure scenario.

In many cases the concentrations of the substances of interest that occur in the porewater in an application with a granular or size reduced aggregate will represent the highest and hence the critical values to be used in the source term. Since there are no restrictions, it should be assumed that the application (or heap) could be relatively high (5 to $10 \mathrm{~m}$ or more) and that the rate of infiltration of precipitation into the application (or heap) and hence the rate of production of leachate could be substantial (e.g. 300 to $350 \mathrm{~mm} /$ year or more under Nordic conditions). As mentioned, for most substances the highest concentrations are seen in the initial porewater (i.e. at low L/S), but some substances, particularly those that are solubility controlled, may show increasing concentrations when the $\mathrm{L} / \mathrm{S}$ ratio increases over a certain range, e.g. due to removal of other substances or due to changes (decreases) in $\mathrm{pH}$ as a result of carbonation. Many relevant waste-derived aggregates, including crushed concrete, will have a relatively high starting pH (typically 10-12.5) that may be reduced over time to more neutral values by natural carbonation). The testing should reflect the effects of the possible change of $\mathrm{pH}$ over time. 


\subsubsection{The pathway}

In this case of unrestricted use the pathway is simple: Due to the lack of restrictions, it is necessary to assume that the material can be placed in direct contact with the receptor, which can be groundwater or surface water, so there is no pathway along which attenuation of released substances can take place. The source is discharged directly into the receptor.

\subsubsection{The receptor}

The receptor will be groundwater or surface water. It is proposed to use either national values or European values as the primary water quality criteria (WQC). In this calculation example, the lowest values found in the first four columns of Table 2, i.e. drinking water and groundwater criteria as well as surface water quality criteria (fresh water), have been chosen to take into account the worst possible situation. The calculations in section 5.3.4 are fairly simple, so other water quality criteria can easily be substituted and used instead. For the sake of this example, the limit values have been calculated only for the primary WQC corresponding to the substances for which the EU WAC for inert waste landfills were set. If EoW criteria for aggregates are developed (with or without restrictions on the use), it will probably be necessary to consider a broader range of substances for which primary WQC should be selected and limit values calculated, not the least based on requirements of the Water Framework Directive and its implementation. The rather stringent acceptance criterion is simply that the calculated porewater concentration in the C\&D material/crushed concrete must not exceed the chosen WQC. No dilution is assumed.

\subsubsection{Calculation of leaching criteria}

The "translation" of leaching criteria from one L/S value to another based on the assumption of an exponential decrease of the concentration of released substances with $\mathrm{L} / \mathrm{S}$ as a function of $\kappa$ is explained in Appendix 6. As mentioned in section 5.3.3, the starting point is that the concentration of the substances in the porewater in the aggregate application should not exceed the chosen primary water quality criteria. If this concentration is $\mathrm{C}$, it is equivalent to a leached amount of $\mathrm{E}=\mathrm{C} \times 0.2 \mathrm{mg} / \mathrm{kg}$ at $\mathrm{L} / \mathrm{S}=$ $0.2 \mathrm{l} / \mathrm{kg}$, which is the estimated $\mathrm{L} / \mathrm{S}$ value corresponding to the pore water condition, i.e., the pore volume for a material with a dry bulk density of $2 \mathrm{~kg} / \mathrm{l}$ and a porosity of $40 \%$ (see Appendix 6). Using equation (A6.4) in Appendix 6 and the kappa values shown in Table 37 in the same appendix, the leached amounts of the substances at $\mathrm{L} / \mathrm{S}=2 \mathrm{l} / \mathrm{kg}$ and $\mathrm{L} / \mathrm{S}=$ 
$10 \mathrm{l} / \mathrm{kg}$ corresponding to the values determined for $\mathrm{L} / \mathrm{S}=0.2 \mathrm{l} / \mathrm{kg}$ are calculated. The limit values can be compared to results of the percolation leaching test CEN/TS 14405 (accumulated leached amounts) at the corresponding $\mathrm{L} / \mathrm{S}=0.2 \mathrm{l} / \mathrm{kg}, \mathrm{L} / \mathrm{S}=2 \mathrm{l} / \mathrm{kg}$ and $\mathrm{L} / \mathrm{S}=10 \mathrm{l} / \mathrm{kg}$. They can also be compared to the results of the batch leaching tests EN 12457-1 (L/S = $2 \mathrm{l} / \mathrm{kg}$ ), EN 12457-2 (L/S = $10 \mathrm{l} / \mathrm{kg}$ ) and EN 12457-3 (L/S = 2 and $10 \mathrm{l} / \mathrm{kg}$ ). And at $\mathrm{L} / \mathrm{S}=10 \mathrm{l} / \mathrm{kg}$ they can be compared to the results of the $\mathrm{pH}$ dependence tests CEN/TS 14997 and CEN/TS 14429 at L/S = 10 l/kg carried out at relevant $\mathrm{pH}$ values. The leaching tests are described in Appendix 7. Compliance with the limit values at the higher $\mathrm{L} / \mathrm{S}$ ratios of 2 and $10 \mathrm{l} / \mathrm{kg}$ ensures that the WQC will also be met at the End-of-Life/crumbled/carbonated state of the aggregates as discussed above. The water quality criteria and the kappa values used are shown in Table 3 together with the calculated limit values at the three values of $\mathrm{L} / \mathrm{S}$. The table also shows the EU acceptance criteria for landfills for inert waste for comparison.

It is evident from Table 4 that the calculated leaching limit values for EoW without restrictions or conditions are extremely stringent and they will most likely be impossible difficult to comply with for most wastederived aggregates. The resulting limit values at $\mathrm{L} / \mathrm{S}=10 \mathrm{l} / \mathrm{kg}$ are up to 960 times lower than the EU WAC for inert waste landfills for some substances. 
Table 4: The calculated leaching limit values at $\mathrm{L} / \mathrm{S}=0.2 \mathrm{l} / \mathrm{kg}, 2 \mathrm{l} / \mathrm{kg}$ and $10 \mathrm{l} / \mathrm{kg}$ for EoW for aggregates without restrictions and control of the use. The table also shows the water quality criteria and kappa values used in the calculation of the limit values. The EU WAC at $L / S=10 \mathrm{l} / \mathrm{kg}$ for inert waste landfills are shown for comparison. Phenol = phenol index

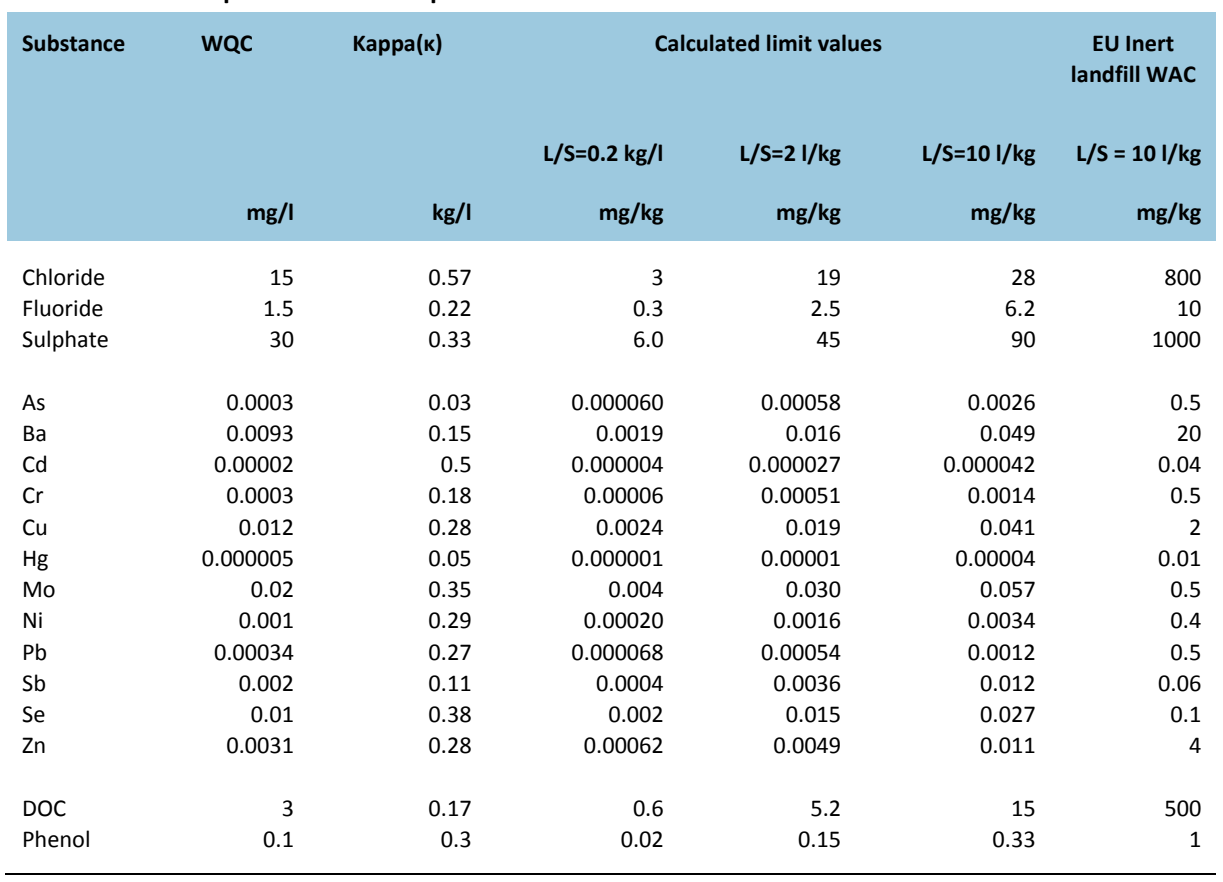

Note: The WQC are the lowest groundwater or fresh water values from Table 1.

The $\mathrm{k}$ values used are those used in the calculation of the EU WAC for landfilling of inert waste.

The EU Inert landfill WAC are those listed in EU Council Directive 2003/33/EC.

\subsection{Conditions that can modify EoW leaching limit values}

Some of the conditions that could be imposed on the use of a given wastederived aggregate with EoW status are listed in Table 5 which also indicates which parts of the source-pathway-receptor chain will be affected (in terms of modelling conditions) by the measures taken.

The two most basic requirements that will set the scene for the proposed methodology for development of leaching limit values as part of EoW criteria are: 
- The aggregate can only be used for specified purposes.

- The aggregate must be taken back by the user/owner at the end of its service life.

The first of these requirements is already implied in indent a) in Article 6 (1) of the WFD, but it should be further specified and refer to one or more specific scenario type(s), e.g. use as sub-base in a road or a filling material in an embankment. This requirement could then lead to more than one set of limit values (corresponding to different application purposes) or, if that is considered impractical, to the adoption of the most restrictive of these for all the relevant purposes.

The second requirement, which is for example already part of the Dutch Soil Quality Decree (SQD) that sets criteria for use of both products and waste materials, will, together with the first requirement, ensure that the risk assessment only has to be performed for specific, relevant in-use scenarios (as opposed to the very conservative scenario applied in the case of free or unrestricted use), albeit always assuming that the material is granular. However, this requirement would still need consideration of aggregate alterations (e.g. carbonation) that may enhance the leaching of substances during the service life. The practical implementation of this requirement will probably require some careful consideration of measures to ensure that the responsibility remains with someone, if ownership and other conditions change in the course of a long service life.

In the following discussion and in the presentation of a methodology for development of limit values in section 5.5 it is assumed that these two basic requirements are mandatory.

One, several or all of the following requirements (3 to 7 in Table 4) are in principle optional and can be chosen to protect the environment and allow for conditions that will lead to less stringent leaching limit values. Specifications of conditions 1 and 3 to 7 will, under all circumstances, be required as input to the impact modelling. A limited set of different levels of limit values could be created by assembling various combinations of requirements that would lead to increasingly stricter limit values. The requirements have not been invented for this purpose; most of them are already applied in waste legislation.

Requirement no. 3, that there must be a minimum distance from the application to the surface of the groundwater will provide protection of the groundwater while allowing the risk-based methodology for assessment of the leaching limit values to take into account the attenuation of released substances in the unsaturated zone. Compared to a situation 
without such a minimum distance, this will result in higher limit values for most substances.

Requirement no. 4, that there must be a minimum distance from the application to a surface water body (providing the surface water body is the receptor), will protect the surface water body from released substances from the aggregate application while allowing for attenuation in the aquifer, i.e. the pathway between the groundwater directly below the application and a downstream surface water body. All other conditions equal, the resulting leaching limit values will increase with increasing length of pathway, i.e. increasing distance to a surface water receptor.

Requirement no 5, restrictions on the height of the application, will generally modify the source term in the sense that it will decrease faster as a function of time with decreasing application height. In general, a faster decrease in source strength may lead to higher (i.e. less restrictive) leaching limit values.

Requirement no. 6, restrictions on the length and width of the application, will in situations of horizontal flow towards a downstream POC generally limit the source term in a similar manner as for requirement 5 (i.e. faster decline as a function of time) and may hence allow for less restrictive limit values. The length of the application in the direction of the groundwater flow has the strongest influence on the impact at a point of compliance (POC) and the limit values.

Requirement no. 7, restrictions on the allowed rate of infiltration, has a strong influence on the source strength and, consequently, on the resulting leaching limit values. Such restrictions can occur naturally from the nature of the applied material (low permeability or monolithic character), and they can be imposed in terms of a required top cover with a specified maximum permeability or quality (e.g. only use under asphalt cover of a certain quality).

It is important to note that, particularly for requirements $5-7$, the magnitude of the potential increase of limit values for specific substances, relative to those for unrestricted use, depends strongly on (regulatory) choices with regard to the location of the POC, the (water) quality criteria, and the time frame considered.

Some of the conditions of use listed in Table 5 may possibly be derived and specified from the appropriate harmonised product standards for aggregates. 


\begin{tabular}{|c|c|c|c|c|}
\hline No & Imposed condition & Source & Pathway & Receptor \\
\hline 1 & $\begin{array}{l}\text { The material can only be used } \\
\text { for specified purposes }\end{array}$ & Can be influenced & Can be influenced & $\begin{array}{l}\text { May determine } \\
\text { which receptors } \\
\text { are relevant }\end{array}$ \\
\hline 2 & $\begin{array}{l}\text { Take back the material after } \\
\text { service life }\end{array}$ & $\begin{array}{l}\text { Reduction in the } \\
\text { time span to be } \\
\text { considered }\end{array}$ & Not affected & Not affected \\
\hline 3 & $\begin{array}{l}\text { Minimum distance to ground- } \\
\text { water level }\end{array}$ & Not affected & $\begin{array}{l}\text { Attenuation in the un- } \\
\text { saturated zone may be } \\
\text { taken into account }\end{array}$ & Depends on POC \\
\hline 4 & $\begin{array}{l}\text { Minimum distance to surface } \\
\text { water }\end{array}$ & Not affected & $\begin{array}{l}\text { Attenuation in the un- } \\
\text { saturated zone and the } \\
\text { aquifer may be taken } \\
\text { into account }\end{array}$ & Depends on POC \\
\hline 5 & $\begin{array}{l}\text { Restrictions on height of } \\
\text { application }\end{array}$ & $\begin{array}{l}\text { May reduce source } \\
\text { term }\end{array}$ & Not affected & Not affected \\
\hline 6 & $\begin{array}{l}\text { Restrictions on the length and } \\
\text { width of the application }\end{array}$ & $\begin{array}{l}\text { May reduce the } \\
\text { source term }\end{array}$ & Not affected & Not affected \\
\hline 7 & $\begin{array}{l}\text { Restrictions on allowed rate of } \\
\text { infiltration }\end{array}$ & $\begin{array}{l}\text { Reduction of the } \\
\text { flux (the load per } \\
\text { time unit) }\end{array}$ & Not affected & Not affected \\
\hline
\end{tabular}

Another restriction that is not mentioned in the table could be a minimum distance to drinking water extraction wells.

\subsection{EoW leaching criteria with restrictions/ conditions on the use}

\subsubsection{Overview}

This section describes a generic stepwise modelling approach based on the source-pathway-receptor relationship that can be used to develop leaching limit values for EoW for waste-derived aggregates. The approach is in agreement with the principles described in EN 12920: "Characterisation of waste - Methodology for the determination of the leaching behaviour of waste under specified conditions", and it is also applicable to the setting of criteria for utilisation of the materials under waste legislation. It is based on the same fundamental principles that have been applied in the setting of the EU leaching criteria for acceptance of waste at inert 
waste landfills (see Appendix 8) and in the development of leaching criteria for application of virgin and waste materials under the Dutch Soil Quality Decree (SQD, 2007). The principles applied have been accepted by CEN/TC 351 in connection with the implementation of ER3 in the CPD, and the methodology has been adopted by the Danish Environmental Protection Agency when implementing Council Decision 2003/33/EC (on landfill WAC) and when setting leaching criteria for the use of slightly polluted soil, and by the Swedish Environmental Protection Agency when developing guidelines for utilisation of waste materials (Naturvårdsverket, 2010).The steps in the procedure are:

- Step 1: Description of the application type and the imposed conditions.

- Step 2: Description of the relevant receptor(s) and the primary water quality criteria.

- Step 3: Description and modelling of the source term.

- Step 4: Description and modelling of the migration of substances from the source to the point of compliance (pathway).

- Step 5: Assessment of the impact at the receptor and reverse modelling or iteration to adjust the source term.

- Step 6: Transformation of source term criteria to specific limit values.

- Step 7: Assessment of the resulting limit values and possible repetition of the stepwise procedure.

- Step 8: Taking other considerations into account.

\subsubsection{Step 1: Description of the application type and the imposed conditions}

The first step should be to determine which types of applications and conditions will be relevant (requirement 1, Table 5). This should be done with reference to the aggregate product standards. Realistic specifications and ranges of conditions 5, 6, 7 (Table 5) should be generated and ranges for conditions 3 and 4 in Table 5 should be determined The step should result in a limited number of specified application scenarios and ranges of conditions to be used for the source modelling in step 3. If the result of the assessment in step 7 is that the calculated limit values are too low, then the imposed conditions chosen for the scenarios in question could be reconsidered and changed, and the stepwise procedure repeated. 


\subsubsection{Step 2: Description of the relevant receptor(s) and the primary water quality criteria}

In this step, the WQC to be complied with at the point(s) of compliance in groundwater and surface water should be determined. If the EoW criteria are to be generally applicable within the EU, then the WQC should be agreed on by all Member States, and in principle they should represent the lowest criteria found in any Member State. When selecting the WQC for these purposes, due consideration must also be taken to the implementation of the Water Framework Directive and the Groundwater Directive (see also section 5.1.3) It is proposed to produce a long-list of substances for which primary WQC should be determined, based on input from all Member States. When individual materials are to be tested for comparison to the EoW limit values, the programme may be reduced to a short-list of substances relevant for that material, based e.g. on the dossier to be prepared. A further important criterion to be selected in this step is the time frame to be considered for the assessment of the potential impact at the POC.

If, as a first attempt and an example, a minimum distance to the groundwater of e.g. $1 \mathrm{~m}$, and a minimum distance to surface water bodies of e.g. $30 \mathrm{~m}$ are chosen, then a POC (groundwater QC) in the groundwater at the interphase between the unsaturated and saturated zone could be considered as well as a POC (surface water QC) in the groundwater at the interphase between the groundwater and the surface water. The POC leading to the lowest limit values (after step 6) should then be adopted for that particular scenario.

\subsubsection{Step 3: Description and modelling of the source term}

Each of the application scenarios chosen in step 1 must be described in detail in terms of height, width, length, hydraulic conductivity, dry bulk density, porosity, and net rate of infiltration through the top cover. A water balance should be set up for the application. Based on equation (A6.1 in Appendix 6) a relationship between the average L/S for the application and time can be established. Since the source will change with time and progression of the leaching processes and the result will be used as input to models describing the transport of the substances through the unsaturated zone and the aquifer, it is useful to express the source analytically as function of time and/or L/S. For the sake of simplicity it is assumed that the release of each substance to be considered can be described as an exponentially decreasing function of time or L/S (although this is not entirely true for all substances). The source term can then be described by 
equation (A6.2 in Appendix 6) where $C_{0}$ is the initial peak concentration of the substance occurring at the bottom of the application or in a percolation test performed on one of the materials to be considered. For each substance a kappa value, which describes the rate of decrease of the concentration in the eluate as a function of $\mathrm{L} / \mathrm{S}$, is required (see Appendix 6). Again for the sake of simplicity, it is assumed that the kappa values are independent of the waste material (and again, this may not be entirely true). Currently, kappa values are available for $\mathrm{As}, \mathrm{Ba}, \mathrm{Cd}, \mathrm{Co}, \mathrm{Cr}, \mathrm{Cu}, \mathrm{Hg}$, $\mathrm{Mo}, \mathrm{Ni}, \mathrm{Pb}, \mathrm{Sb}, \mathrm{Se}, \mathrm{Sn}, \mathrm{V}, \mathrm{Zn}$, cyanide, bromide, chloride, fluoride and sulphate (see Appendix 6). Most likely, the long-list of substances with WQC will include substances for which no kappa values yet exists. Such kappa values will then have to be derived from percolation tests on relevant materials. The resulting source term describes the flux (e.g. in mass per unit time) as a function of time of each of the substances of interest released into the unsaturated zone below the application. Since condition 2 in Table 5 is assumed to be mandatory, the material in the application will be removed at the end of the service lift of the aggregate, and flux becomes zero at that point in time.

\subsubsection{Step 4: Description and modelling of the pathway}

The next step will be to describe and model the transport of the substances along the pathway to the receptor(s) and the point(s) of compliance, first through the unsaturated zone to the surface of the groundwater below the application, and then (if required) through the aquifer to a point of compliance at some distance downstream of the application. For this purpose it is necessary to develop hydrogeological and geochemical scenario description including information on the thickness and hydraulic conductivity of the unsaturated zone, the retention properties of the unsaturated zone (i.e. a measure of the interaction between the substances in the leachate and the soil) and the general rate of (rainwater) infiltration for the area. Additional hydrogeological information in varying degrees of detail will be required, depending on the model chosen. The background concentration of the substances considered in the groundwater should also be determined. The scenario conditions should be selected in such a way that they represent the chosen scenario as realistically as possible. Once the transport models have been selected and run, it is recommended to test the sensitivity of the results towards changes in the various conditions. 
The above boundary conditions should be incorporated into appropriately chosen (numeric) transport models. It is often most convenient to use a set-up which combines the unsaturated and saturated zone transport in a single model. It is recommended to use a $3 \mathrm{D}$ model. Most state-of-the-art models are based on the same fundamental groundwater transport equations and may be expected to give the same results for the same input. The models may, however, differ in the way they handle substance transport and account for soil/leachate interaction processes that occur in the unsaturated zone and the aquifer, and the input requirements may differ accordingly. The model(s) chosen should as a minimum be able to incorporate the effect of sorption/ion exchange e.g. either by use of a simple linear partitioning coefficient (Kd), (non-linear) transfer functions ${ }^{10}$ or by applying geochemical modelling.

Even though the source is interrupted at the end of the service life of the application, the transport modelling should continue until the impact at the POCs has peaked.

\subsubsection{Step 5: Assessment of the impact at the receptor and reverse modelling/iteration}

The result of the pathway modelling is a description of the concentration of each of the substances as a function of time at the POC(s). Due to the dispersion and attenuation effects and the decreasing nature of the source those concentrations will increase with time, show a peak, and then decrease. The peak thus represents the maximum impact on the receptor (in this case the groundwater at the POC below the application or the groundwater at the POC downstream of the application) that will occur over time. Depending on the substance, the thickness and character of the unsaturated zone and the aquifer, the groundwater flow velocity and the distance to the POC(s), the time until the peak occurs may vary between a few years and several thousand years. It could be a matter of debate whether or not an environmental impact that is predicted to occur after several thousand years is meaningful and should be taken into account (given model uncertainties, particularly over such long time frames). Alternatively, a time limit of e.g. 500 or 1,000 years could be introduced. If the transport modelling is interrupted after this period, some of the sub-

\footnotetext{
${ }^{10}$ See, e.g., Groenenberg, J.E., Römkens, P.F.A.M., Comans, R.N.J., Luster, J., Pampurad, T., Shotbolt, L., Tipping, E. \& de Vries, W. (2010). Transfer functions for solid-solution partitioning of cadmium, copper, nickel, lead and zinc in soils: derivation of relationships for free metal ion activities and validation with independent data. European Journal of Soil Science 61, 58-73.
} 
stances may never be observed to reach the peak value. The highest concentration - corresponding to a point on the increasing slope of the concentration vs. time curve at the POC - would be the endpoint where the calculation was stopped. This would lead to leaching limit values for these substances that are higher than they would have been if the modelling had been continued until the peak occurred. For very immobile substances that do not show any significant increase at the POC within the selected time frame, alternative criteria may be based on compliance with soil quality criteria, averaged over a certain soil volume along the pathway (see e.g. SQD, 2007).

When calculating the resulting concentration at the POCs in the groundwater, a decision has to be made of whether to assume total vertical mixing of the plume (averaging the concentration over the entire depth of the aquifer) or whether to use for example the average concentration level over part of aquifer depth.

If a linear Kd relationship has been used to describe the retention of substances in the model, then the relationship between the initial peak concentration at the bottom of the application, $\mathrm{C}_{0}$, and the peak concentration at the POC in the aquifer, $\mathrm{C}_{\mathrm{P}}$, is also linear for a given substance and application. The ratio between the two, $C_{P} / C_{0}=f_{a}$, is called the attenuation factor for that particular scenario and substance. If a water quality requirement, $\mathrm{WQC}$, is then imposed on the groundwater at the POC $\left(\mathrm{C}_{\mathrm{P}}\right)$, this means the corresponding requirement on the source term, $\mathrm{C}_{0}$, can be calculated as follows:

$\mathrm{C}_{0}=\left(1 / \mathrm{f}_{\mathrm{a}}\right) \times\left(\mathrm{C}_{\mathrm{P}}-\mathrm{C}_{\mathrm{BG}}\right)+\mathrm{C}_{\mathrm{BG}}$

where $\mathrm{C}_{\mathrm{BG}}$ is the background concentration of the substance in the groundwater upstream of the application.

If geochemical modelling is used to describe the retention of substances along the pathway from the source to the POC (or if a non-linear relationship between the substances in the solid and the aqueous phase is used to describe the retention), then the relationship between $\mathrm{C}_{0}$ and $C_{P}$ will be non-linear, and the value of $C_{0}$ corresponding to $C_{P}=W Q C$ will have to be found by iterative modelling.

A linear Kd description of the retention was used in the development of the leaching WAC for inert waste landfills (see Appendix 8), whereas geochemical modelling was applied in the development of the leaching limit values associated with the Dutch SQD (see Annex 7). 


\subsubsection{Step 6: Transformation of source term criteria to specific limit values}

Once the value of $\mathrm{C}_{0}$ corresponding to the WQC for a given application scenario and substance has been established - and still assuming that the release of the substance can be described as an exponentially decreasing concentration as a function of time - the result can be expressed in terms of a limit value, release $E_{\mathrm{LV}}(\mathrm{mg} / \mathrm{kg})$, for a percolation or batch leaching test performed at a specified (accumulated) L/S value:

$\mathrm{E}_{\mathrm{LV}}=\left(\mathrm{C}_{0} / \kappa\right) \times\left(1-\mathrm{e}^{-(\mathrm{L} / \mathrm{S}) \kappa}\right)$

This allows the limit value to be adjusted to the preferred test method or test conditions in terms of L/S (usually $2 \mathrm{l} / \mathrm{kg}$ or $10 \mathrm{l} / \mathrm{kg}$ or both).

\subsubsection{Step 7: Assessment of the results and possible repetition}

When the limit values for the entire suite of substances have been established on the basis of this scenario- and risk-based approach, the compliance of relevant C\&D waste-derived aggregates with these values can be assessed based on the results of appropriate leaching tests. If it is felt that the limit values are too restrictive (too low), the step-wise procedure can be repeated, starting by applying more stringent conditions in step 1 . As a rule of thumb, a thicker unsaturated zone, a longer distance to surface water bodies/POC, a more shallow and smaller application, and a lower rate of infiltration will all influence the calculations in the direction of less stringent (higher) limit values, the magnitude of which being dependent also on other criteria such as the quality criteria for water/soil at the POC and the time frame. If, on the other hand, it is felt that some of the leaching limit values are too permissive (too high), then they can be restricted based other considerations.

\subsubsection{Step 8: Taking other considerations into account}

The leaching limit values calculated in steps 1 through 7 only consider the resulting impact on downstream groundwater (or surface water), and the applied modifying conditions as shown in Table 4 may play a considerable role in mitigating the downstream effects, provided that they are actually incorporated into the use application. Other factors such as national waste/environmental policy, risk of failure, risk of interaction with other 
substances, processes or equipment, physical properties and appearance of the material, consistency with other legislation, etc. should also be considered and may give rise to changes and adjustments of the calculated limit values. Some of these issues may be taken care of by requirements on the origin and pre-treatment of the C\&D waste whereas others may have to be reflected in (modifications of) the limit values. Some examples of such issues could be:

- The reluctance to create a number of potential landfills (a requirement could be that the leaching (or content) limit values should not exceed those for landfilling at inert waste landfills or at non-hazardous waste landfills receiving stable, non-reactive hazardous waste).

- The reluctance to have EoW limit values for C\&D waste that are higher than or even equal to national limit values for utilisation of waste materials or soil in construction engineering works (adjustment may be required even though the conditions may be different).

- The risk that a substance that has a high limit value because of a low impact at the POC may influence other substances and for example increase their solubility and leachability. This could e.g. be the case with high concentrations of DOC, chloride and sulphate.

- The risk of causing damage to structures or processes (sulphate in higher concentrations may cause corrosion of concrete, and if biodegradable material is present, it may form toxic and smelly hydrogen sulphide). This may in some cases call for a reduction of calculated limit values for sulphate.

If the EoW criteria are set on a national basis and import/export of the material as a product can be effectively prevented, it will be reasonably straightforward to take such issues (and others) into account. If the EoW criteria are set at EU level with free trade and transport, it becomes more difficult and will actually require that the most stringent requirements in any member state are adopted. 


\subsection{Testing and documentation requirements}

\subsubsection{Dossier and testing framework}

For practical reasons and to avoid redundant testing, it could be useful to prepare a dossier to document compliance with the requirements on leaching (and content) of substances for which limit values are set and any other requirements of crushed concrete (or any other aggregate) to be considered for EoW status. The preparation of such a dossier would correspond to the procedure required for CE marking under the CPD/CPR.

To be approved for EoW status, it should be shown that a number of samples of the aggregate, representing a realistic cross-section of the material in question in the form it will have when it is to be used, comply with the criteria developed for leaching as well as with any criteria set on the content of substances. Existing data of good quality should also be included. A convention should be established for the statistical requirements for compliance with the limit values. If the dossier indicates a reasonable degree of compliance with the limit values at the level of characterisation or initial type testing (ITT), rules for routine testing (compliance testing or factory production control (FPC) in terms of frequency, sampling requirements, test methods and pass/fail conventions should be established. ITT and FPC are procedures established within CE marking under the Construction Products Directive, CPD (89/106/ECC) and its successor the Construction Product Regulation, CPR (Regulation (EU) No 305/2011). ITT can be seen as the product equivalent to basic characterisation as it is defined in waste legislation (e.g. in the Landfill Directive, 1999/31/EC, and the associated Council Decision, 2003/33/EC), and FPC may in principle be the product equivalent to compliance testing as defined in the same legislation, although FPC would probably have to have a higher frequency than compliance testing normally does.

\subsubsection{Sampling}

When testing waste materials or products the first step will always be to obtain a "representative" sample of the material to be tested. When sampling a waste aggregate (a C\&D waste) for the purpose of assessment of compliance with possible of EoW criteria, it is particularly important that the sample(s) to be tested represent all possible variations of the quality of the product. If it is a routine testing of a specific batch of the material, then the sample(s) collected should be representative of that particular batch. It is always a challenge to ensure that the small amount of material 
which is eventually tested is truly representative of the population from which it is sampled, and the importance of employing proper sampling (and pre-treatment) procedures has often been underestimated. However, during recent years the focus on sampling has increased, and several sampling protocols for waste aggregates have been developed, in particular by CEN. Sampling will not be addressed further in this context but proper sampling is crucial if reliable results of tests and analyses are to be obtained, and reference is made to the sampling standards and guides developed by CEN/TC 292, CEN/TC 351 and the product committees (e.g. CEN/TC 154: Aggregates).

\subsubsection{Testing of leaching properties}

It is proposed that the leaching testing under ITT for the dossier should include a percolation test (CEN/TS 14405 or CEN/TC 351/WG1 TS-3), a pH dependence test (CEN/TS 14429 or CEN/TS 14997) and a batch leaching test EN 12457-part 1, 2 or 3 (for future FPC purposes). Criteria for unrestricted use (which are not likely to be set) such as those 5.4 should be met at both $\mathrm{L} / \mathrm{S}=0.2 \mathrm{l} / \mathrm{kg}, \mathrm{L} / \mathrm{S}=2 \mathrm{l} / \mathrm{kg}$ and $\mathrm{L} / \mathrm{S}=10 \mathrm{l} / \mathrm{kg}$ by the col$\mathrm{umn} /$ percolation test results and they should also be met by the batch test results (either at $\mathrm{L} / \mathrm{S}=2 \mathrm{l} / \mathrm{kg}$ or $10 \mathrm{l} / \mathrm{kg}$ ) and the results of the $\mathrm{pH}$ dependence test (at $\mathrm{L} / \mathrm{S}=10 \mathrm{l} / \mathrm{kg}$ ) for $\mathrm{pH}$ between 7.0 and the material's own $\mathrm{pH}$ (generally alkaline for crushed concrete). EoW leaching limit values developed for use with restrictions/conditions, e.g. by the procedure described in section 5.5, should be met by the same tests, however only at $\mathrm{L} / \mathrm{S}=2 \mathrm{l} / \mathrm{kg}$ and $\mathrm{L} / \mathrm{S}=10 \mathrm{l} / \mathrm{kg}$ by the column/percolation test results and they should also be met by the batch test results (at $\mathrm{L} / \mathrm{S}=2 \mathrm{l} / \mathrm{kg}$ or 10 $\mathrm{l} / \mathrm{kg}$ ) and the results of the $\mathrm{pH}$ dependence test (at $\mathrm{L} / \mathrm{S}=10 \mathrm{l} / \mathrm{kg}$ ) for $\mathrm{pH}$ between 7.0 and the material's own $\mathrm{pH}$. The leaching tests are described in Appendix 7.

If a discrepancy of compliance occurs between the percolation test and the batch test, the results of the percolation should take precedence. A producer/applicant should have the choice to use the percolation test (recovering a single eluate at $\mathrm{L} / \mathrm{S}=2 \mathrm{l} / \mathrm{kg}$ or $\mathrm{L} / \mathrm{S}=10 \mathrm{l} / \mathrm{kg}$ ) instead of the batch test for FPC purposes.

At ITT level the eluates from the leaching test should be analysed chemically for $\mathrm{pH}$, conductivity and possibly redox potential (part of the testing procedure), chloride, sulphate, fluoride, $\mathrm{Al}, \mathrm{Si}, \mathrm{Ca}, \mathrm{Na}, \mathrm{K}, \mathrm{As}, \mathrm{Ba}, \mathrm{Cd}$, $\mathrm{Cr}, \mathrm{Cu}, \mathrm{Hg}, \mathrm{Mn}, \mathrm{Mo}, \mathrm{Ni}, \mathrm{Pb}, \mathrm{Sb}, \mathrm{Se}, \mathrm{Sr}, \mathrm{V}, \mathrm{Zn}$ and DOC. If inorganic substances are added to the list of substances of concern (e.g. Table 2), these substances should be included in the analytical programme. At FPC level the 
analytical programme for the eluates could be the same. The reason for including several substances that are generally not considered problematic in relation to environment and health in the analytical programme is that many of these (the "major" ions) determine the chemical conditions and control the release of the contaminants of concern, and they provide information about trends and causes of release of substances of concern. When using ICP-based chemical analytical equipment, the number of substances analysed is only a minor factor influencing the cost.

\subsubsection{Determination of content}

For the preparation of the dossier and for ITT purposes, the aggregate under assessment should be analysed for content of a wide range of inorganic and organic substances. The inorganic substances should include: $\mathrm{Si}, \mathrm{Al}, \mathrm{Ca}, \mathrm{Mg}$, Ti, Na, K, Fe, S, , As, Ba, Cd, Cr, Cu, Hg, Mn, Mo, Ni, Pb, Sb, Se, $\mathrm{Sr}, \mathrm{V}$ and $\mathrm{Zn}$. $\mathrm{Cl}$ can be determined on the basis of a leaching test. The purpose of including substances that are not considered critical in relation to environment and health is to enable the total composition mass balance to be closed (based on the presence of major substances as oxides, carbonates, sulphates and chlorides). This should be done only on a few representative composite samples at ITT level. Subsequent FPC testing should focus on the substances of concern such as those shown in Table 3 (with changes as required). The ITT and possibly also FPC testing should include determination of TOC. Minimum requirements for analysis of content at ITT level should include PCB, BTEX, PAH and hydrocarbons, but could include additional organic substances e.g. as a result of on-going or recently finalised studies. The analytical programme for determination of organic substances at FPC level will depend on the ITT findings and the relevant (waste) legislation.

\subsection{Selected examples of scenario calculations}

\subsubsection{Description of scenarios}

In order to illustrate the applicability of the methodology described in section 5.5, the method has been applied to a few selected scenarios where C\&D waste is used as sub-base or base layer in a road (a shallow application) and as filling material in a larger structure, e.g. a noise reduction barrier or a ramp. The scenarios have been chosen to illustrate the influence of various physical conditions such as height, length, width and 
cover (rate of infiltration) on the resulting limit values. Both types of scenarios are relevant under Nordic conditions.

The road considered is $14 \mathrm{~m}$ broad and $286 \mathrm{~m}$ long, and the layer of C\&D waste used is $1 \mathrm{~m}$ thick. In one case (Scenario 1), the rate of infiltration through the road (no cover) is $350 \mathrm{~mm}$ per year which is nearly the same as the general rate of infiltration in the area $(320 \mathrm{~mm}$ per year). The thickness of the unsaturated zone is $2 \mathrm{~m}$, and the groundwater point of compliance (POC) is located downstream at a distance of $30 \mathrm{~m}$ perpendicular to the road. Similar calculation could be carried out for POC located e.g. in a drainage ditch along the road which would most likely give more stringent leaching limit values.

The noise reduction barriers or ramps are $12 \mathrm{~m}$ broad, 12 long and $10 \mathrm{~m}$ high, and $100 \mathrm{~m}$ broad, $100 \mathrm{~m}$ long and 10 and $5 \mathrm{~m}$ high, respectively. No cover is applied, and the rate of infiltration is $350 \mathrm{~mm}$ per year both through the C\&D waste and in the surroundings. The thickness of the unsaturated zone is $2 \mathrm{~m}$, and the groundwater POC is located $30 \mathrm{~m}$ downstream of the application.

In both types of scenarios, the values used for $\kappa$ are those that were used in the calculation of the EU WAC for inert waste landfills (see Table 4 and Appendix 8). The values of Kd used are different from the ones used in setting the EU WAC, they were adapted to Danish conditions, see Table 7 or Table 8 . The primary groundwater/surface water quality criteria to be complied with at the POC are those shown in Table 4 that were also used for the calculation of leaching limit values in the case of unrestricted use. For most substances they are different from the values used when setting the EU WAC for landfilling of inert waste (they are generally much lower).

The scenario conditions are summarised in Table 6.

Table 6: Overview of example scenarios (UZ = unsaturated zone)

\begin{tabular}{lrrrr} 
Scenario & Road scenario & Noise barrier/ramp scenarios & $\mathbf{4}$ \\
& $\mathbf{1}$ & $\mathbf{2}$ & $\mathbf{3}$ & 5 \\
Height $(\mathrm{m})$ & 1 & 10 & 10 & 100 \\
Length (m) & 286 & 100 & 12 & 100 \\
Width (m) & 14 & 100 & 12 & 350 \\
Infiltration (mm/year) & 350 & 350 & 350 & 2 \\
Thickness UZ (m) & 2 & 2 & 2 & 30 \\
Distance to POC (m) & 30 & 30 & 30 & \\
\hline
\end{tabular}




\subsubsection{Modelling results}

The results of the scenario modelling are shown in Table 7 and Table 8 in terms of leaching limit values in $\mathrm{mg} / \mathrm{kg}$ at $\mathrm{L} / \mathrm{S}=2 \mathrm{l} / \mathrm{kg}$ and $\mathrm{L} / \mathrm{S}=$ $10 \mathrm{l} / \mathrm{kg}$, respectively. It should be noted that because of the very low primary water quality criteria, the background concentrations $\left(\mathrm{C}_{\mathrm{BG}}\right.$ in equation (5.1)) were set to 0 for all substances - otherwise the calculations would have resulted in negative limit values for some substances. The numerical soil and groundwater transport model calculates the attenuation factor, $\left(1 / \mathrm{f}_{\mathrm{a}}\right)$, which is then used in equation (5.1) to calculate $\mathrm{C}_{0}$, which in turn is used in equation (5.2) to calculate leaching limit values at $\mathrm{L} / \mathrm{S}=$ $2 \mathrm{l} / \mathrm{kg}$ and $10 \mathrm{l} / \mathrm{kg}$.

\begin{tabular}{|c|c|c|c|c|c|c|c|c|}
\hline \multirow[t]{3}{*}{ Substance } & \multirow{3}{*}{$\begin{array}{c}\text { K } \\
\mathrm{kg} / \mathrm{l}\end{array}$} & \multirow{3}{*}{$\begin{array}{l}\text { Kd } \\
\quad \text { I/kg }\end{array}$} & \multirow{3}{*}{$\begin{array}{l}\text { LV Road } \\
\text { scenario } \\
\text { Scenario } 1 \\
\text { mg/kg }\end{array}$} & \multicolumn{3}{|c|}{ LV Noise barriers/ramps } & \multirow{3}{*}{$\begin{array}{c}\text { LV } \\
\text { Un-restr. } \\
\quad \mathrm{mg} / \mathrm{kg}\end{array}$} & \multirow{3}{*}{$\begin{array}{l}\text { LV Inert } \\
\text { waste LF } \\
\quad \mathrm{mg} / \mathrm{kg}\end{array}$} \\
\hline & & & & Scenario 2 & Scenario 3 & Scenario 4 & & \\
\hline & & & & $\mathrm{mg} / \mathrm{kg}$ & $\mathrm{mg} / \mathrm{kg}$ & $\mathrm{mg} / \mathrm{kg}$ & & \\
\hline Chloride & 0.57 & 0 & 390 & 70 & 440 & 72 & 19 & 550 \\
\hline Fluoride & 0.22 & 2 & 80 & 10 & 63 & 11 & 2.5 & 4.0 \\
\hline Sulphate & 0.33 & 0 & 990 & 170 & 1,060 & 170 & 45 & 560 \\
\hline As & 0.03 & 20 & 0.022 & 0.0025 & 0.015 & 0.003 & 0.00058 & 0.1 \\
\hline $\mathrm{Ba}$ & 0.15 & 14 & 1.1 & 0.086 & 1 & 0.1 & 0.016 & 7.0 \\
\hline $\mathrm{Cd}$ & 0.5 & 20 & 0.0073 & 0.00026 & 0.0014 & 0.00043 & 0.000027 & 0.03 \\
\hline $\mathrm{Cr}$ & 0.18 & 23 & 0.063 & 0.0033 & 0.019 & 0.0046 & 0.00051 & 0.2 \\
\hline $\mathrm{Cu}$ & 0.28 & 100 & 13 & 0.41 & 2.0 & 0.77 & 0.019 & 0.9 \\
\hline $\mathrm{Hg}$ & 0.05 & 20 & 0.00044 & 0.000044 & 0.00026 & 0.00005 & 0.00001 & 0.0030 \\
\hline Mo & 0.35 & 15 & 4.2 & 0.21 & 1.2 & 0.31 & 0.030 & 0.3 \\
\hline $\mathrm{Ni}$ & 0.29 & 20 & 0.26 & 0.012 & 0.065 & 0.017 & 0.0016 & 0.2 \\
\hline $\mathrm{Pb}$ & 0.27 & 100 & 0.37 & 0.011 & 0.056 & 0.021 & 0.00054 & 0.2 \\
\hline $\mathrm{Sb}$ & 0.11 & 7 & 0.14 & 0.016 & 0.097 & 0.018 & 0.0036 & 0.02 \\
\hline $\mathrm{Se}$ & 0.38 & 5 & 0.94 & 0.073 & 0.43 & 0.091 & 0.015 & 0.06 \\
\hline$Z n$ & 0.28 & 20 & 0.78 & 0.036 & 0.20 & 0.053 & 0.0049 & 2 \\
\hline$D O C$ & 0.17 & 0 & 120 & 20 & 120 & 20 & 5.2 & 240 \\
\hline
\end{tabular}




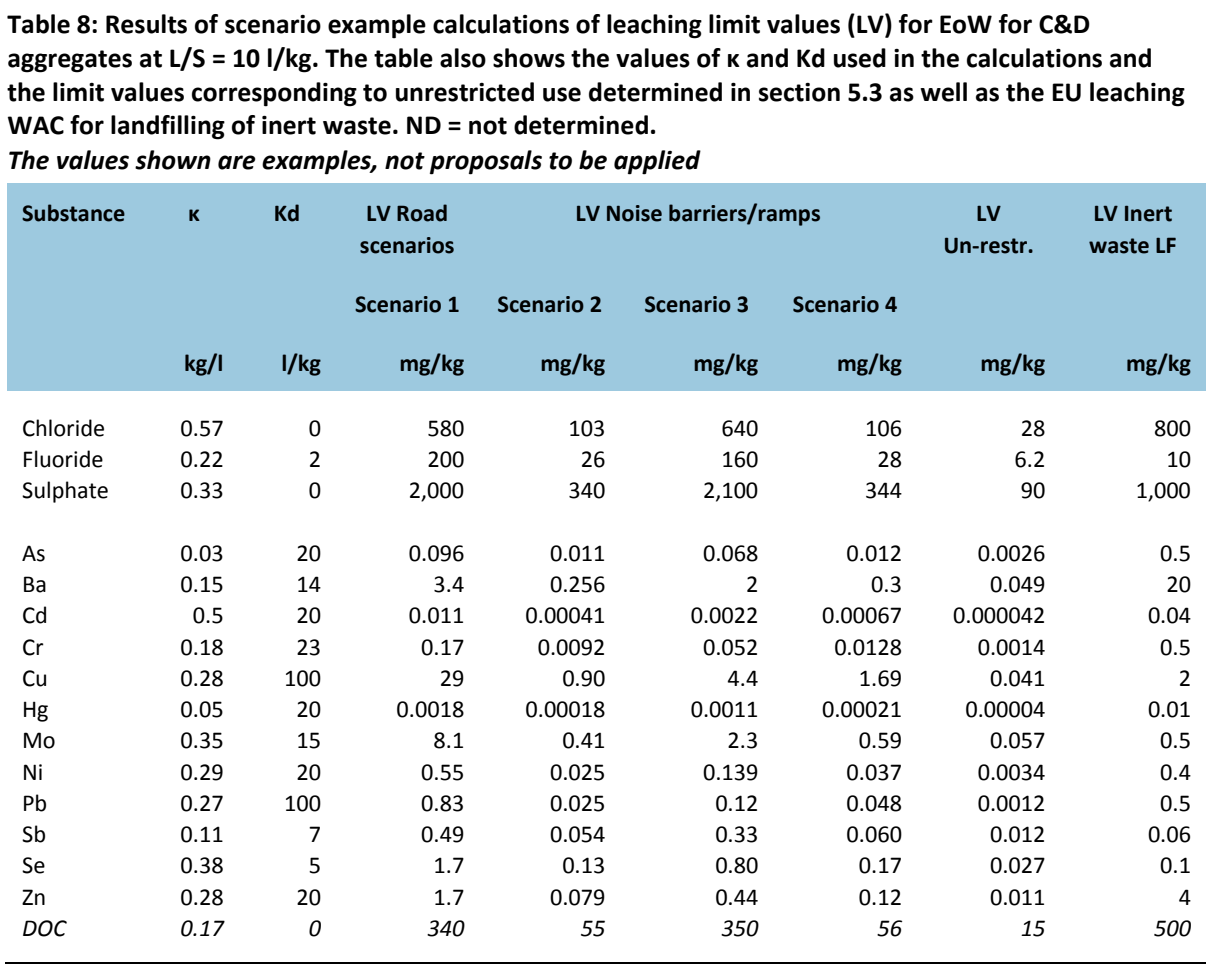

Tables 7 and 8 also show the values of $\kappa$ and Kd used in the modelling calculations. In addition, the limit values found in section 5.3 for unrestricted use of waste aggregates as well as the leaching EU WAC for landfilling of inert waste are also presented in the tables.

It should be noted that the scenario calculation results shown in Table 7 and Table 8 have been produced merely to illustrate the methodology, and they are not proposals for actual EoW leaching criteria. The development of an actual proposal would require careful selection of scenarios and boundary conditions. 


\subsubsection{Discussion of the modelling results}

In general, the least stringent limit values are seen for scenario 1 , the road with a shallow $(1 \mathrm{~m})$ application of C\&D waste and a small width $(14 \mathrm{~m})$ in the direction of the groundwater flow (this is more important than the length perpendicular to the groundwater flow). The rate of precipitation is relatively high, corresponding to a road without pavement. The limit values for the road scenario are much higher than the limit values found in section 5.3 for unrestricted use. With the exception of $\mathrm{As}, \mathrm{Ba}, \mathrm{Cd}, \mathrm{Cr}, \mathrm{Hg}$, $\mathrm{Zn}$, chloride and DOC, all other limit values for the road scenario are higher than the EU WAC for landfilling of inert waste. This is just an example but should lead to consideration of other issues than just the impact on groundwater or surface water and the possible lowering of some of the scenario-based limit values.

The most stringent criteria are found for one of the noise barrier/ramp scenarios, Scenario 2, due to the height $(10 \mathrm{~m})$ and its large width $(100 \mathrm{~m})$ in the direction of the groundwater flow as well as the unrestricted rate of infiltration ( $350 \mathrm{~mm} /$ year). Reducing the width by $88 \%$ to $12 \mathrm{~m}$ increases the limit values approximately by a factor of 4 to 6 , depending on the substance (Scenario 3). Reducing the height to $5 \mathrm{~m}$ only has a minimal effect (Scenario 4). To obtain a substantial effect, the thickness must be reduced to between 0.5 and $1 \mathrm{~m}$. All of the limit values for the barrier/ramp scenarios, with the exception of $\mathrm{Cu}, \mathrm{Mo}, \mathrm{Sb}$, Se, fluoride, the sulphate in Scenario 3, and Se in Scenario 2, are more stringent than the EU WAC for landfilling of inert waste, and all limit values are considerably less stringent than the limit values found in section 5.3 for unrestricted use. Some of the relatively high limit values for the noise barrier/ramp scenarios would also warrant consideration of other issues than just the impact on groundwater or surface water and the possible lowering of some of the scenario-based limit values.

The scenario calculations indicate that conditions such as rate of infiltration, width in the direction of the groundwater flow, and to a certain extent also the height of the application of C\&D waste in a construction project have a substantial influence on the values of the resulting leaching limit values. Other major influences are the substance in question and the primary water quality criteria (the latter has a proportional effect with the model used). 
The few leaching results on fractions of C\&D waste containing only crushed concrete at $\mathrm{L} / \mathrm{S}=2 \mathrm{l} / \mathrm{kg}$ from Denmark (see Appendix 1), indicate that not all of the tested samples comply with the criteria calculated (noncompliance for $\mathrm{Ba}$ and $\mathrm{Cr}$ ). For one sample Ni exceeded the limit value for Scenario 2. The limit values for unrestricted use were exceeded for chloride, sulphate (only one sample), $\mathrm{Ba}, \mathrm{Cr}, \mathrm{Cu}, \mathrm{Hg}$, and $\mathrm{Ni}$. Most of these substances probably originate from the cement itself which means that it is unlikely that compliance can be achieved simply by improved sorting of the crushed concrete fraction.

Work in progress at DHI indicate, based on a large dataset with leaching data on recycled concrete from several countries, but mostly the Netherlands, that the release of $\mathrm{Ba}, \mathrm{Cr}$ and $\mathrm{Pb}$ at $\mathrm{L} / \mathrm{S}=10 \mathrm{l} / \mathrm{kg}$ may in some cases exceed the EU WAC for landfilling of inert waste.

\subsection{Requirements on input materials and pre-treatment of C\&D waste}

Strict controls should be placed on the quality of the input materials. The Nordic countries (Denmark, Finland, Norway and Sweden) already have procedures for selective demolition, depollution of buildings and on-site sorting of C\&D waste/concrete that, if they are followed and properly inspected, probably will be sufficient to ensure a good quality input material. Such procedures can, if they are followed strictly, effectively reduce the contamination of crushed concrete originating from external sources (other materials including asbestos, insulation materials, and plaster boards, paint, diffusing contaminants (PCB, Hg)), but not sources of contamination within the concrete itself (originating from raw materials, e.g. coal fly ash). Studies aimed at improving the demolition and renovation procedures and ensure a high quality of $C \& D$ with the lowest possible risk of unacceptable contamination are on-going e.g. in Denmark (see Appendix 1), and recommendations of new procedures should await the outcome of these studies.

The procedures suggested by the JRC in Delgado et al. (2009), pp. 309 to 312 for C\&D waste (a controlled selective demolition procedure) may be applicable, with the important addition that that factory production control testing and compliance testing on a regular basis will be required for crushed concrete products based on all categories of input materials to ensure that established EoW limit values on content and leaching of 
potentially harmful substances are met. The procedures should be described in much more detail, and both guidelines and rigorous control measures will be required.

The technical requirements on the content of impurities in product standards and guidelines (e.g. for road construction) should be reviewed and possibly revised. The need for requirements on sorting and crushing procedures should be considered. Particular efforts should be made to ensure that, for example, the PCB-containing waste and gypsum/plasterboards are kept out of the product stream.

JRC and some Member States have proposed that the EU leaching WAC for landfilling of inert waste could serve as leaching based EoW criteria. The Swedish EPA has argued strongly against this, because the calculation of the inert waste landfilling WAC were based on various assumptions which are not fulfilled by all relevant EoW use scenarios for C\&D waste. This is, for example, illustrated by the scenario example calculations in section 5.7, where several of the scenarios considered result in leaching limit values that are lower than the EU WAC for landfilling of inert waste. EoW leaching criteria of the same order of magnitude as the EU WAC for landfilling of inert waste may be appropriate, but only in conjunction with specified conditions of the use (see section 5.4), if an impact assessment indicates that it is safe. 



\section{Conclusions and recommendations}

Waste-derived aggregates, including C\&D waste such as crushed concrete, are being considered as possible candidates for development of End-of-Waste criteria at EU level in accordance with Article 6(1) of the EU Waste Framework Directive as a means of increasing the recovery of resources. If and when a waste-derived aggregate achieves EoW status, it will become a (construction) product and hence regulated by the Construction Products Regulation (until 1 July 2013 also the Construction Products Directive) rather than waste legislation which means that in most EU Member States, including the Nordic countries, there will be no applicable environmental protection regulation. The use of recycled waste aggregates for construction purposes are subject to environmental legislation in several EU Member States, but construction products are generally not, except in The Netherlands where environmental protection regulations apply equally to both recycled waste aggregates and virgin aggregates used in construction.

Currently, none of the Nordic countries are planning to take advantage of the option to develop national EoW criteria for C\&D waste or any other waste materials, and in general Denmark, Finland and Sweden express some concern about environmental and health issues if EU-wide EoW criteria for aggregates should be developed by the Commission.

Due to the potential lack of existing environmental protection regulation applying to waste-derived aggregates with EoW status that are used for construction purposes, it is important that the criteria an aggregate must fulfil to achieve and maintain EoW status ensure sufficient protection of the environment and human health. This study has focused primarily on the protection of groundwater and surface water. In the Nordic countries groundwater (particularly in Denmark) and surface water (particularly in Finland, Norway and Sweden) are important sources of drinking water that must be protected. A "worst case" scenario calculation clearly indicates that if the EoW criteria do not include specified conditions for the use of waste-derived aggregates (crushed concrete) with EoW status for specific purposes, then leaching limit values aimed at the 
protection of soil, groundwater and surface water will have to be so stringent that very few, if any, waste aggregates can meet them.

Instead it is proposed to impose restrictions and conditions on the use as part of possible future EoW criteria for crushed concrete and other waste-derived aggregates, and a step-wise methodology for development of more realistic leaching limit values for EoW is outlined. The methodology incorporates the mitigating effects of various measures that reduce the potential environmental impact of construction applications with waste-derived aggregates. Example calculations indicate that application of this procedure will lead to leaching limit values that are substantially higher than for free use without restriction and for several substances of the same order of magnitude as the EU waste acceptance criteria for inert waste landfills, depending on the specific use scenario.

As mentioned above, this study primarily addresses the development of EoW leaching criteria aiming at the protection of groundwater, surface water and soil against substances that may be released from the C\&D waste by leaching. However, the protection of human health against exposure through inhalation, ingestion, direct contact with and occupational exposure to $\mathrm{C} \& \mathrm{D}$ waste is equally important, but it is assumed that existing national legislation and/or guidance in the Nordic countries on maximum contents of (dangerous) substances can be adopted and serve as EoW criteria for this purpose. The EoW criteria should therefore include limit values both on content and leaching of relevant substances.

Finally some recommendations of requirements on input materials and pre-treatment of C\&D waste (crushed concrete) are given. It is recommended that strict controls should be placed on the quality of the input materials. The Nordic countries (Denmark, Finland, Norway and Sweden) already have procedures for selective demolition, depollution of buildings and on-site sorting of C\&D waste/concrete that, if they are followed and properly inspected, probably will be sufficient to ensure a good quality input material. Nevertheless, a quality testing programme for the resulting crushed concrete products is also considered necessary. Recommendations are given concerning the practical testing, analysis and documentation procedures for aggregates with EoW status within the framework of the Construction Products Regulation. 


\section{References}

Aalbers, Th.G., de Wilde, P.G.M., Rood, G.A., Vermij, P.H.M., Saft, R.J., van de Beek, A.I.M., Broekman, M.H., Masereeuw, P., Kamphuis, Ch., Dekker, P.M. and Valejtijn, E.A. (1996). Environmental quality of primary and secondary construction materials in relation to re-use and protection of soil and surface water. RIVM-report no.: 771402007. National Institute of Public Health and the Environment, Bilthoven, The Netherlands.

Andersson-Sköld, Y., Andersson, K. Lind, B., Claesson, A.N., Larsson, L., Suer, P., \& Jacobson, T. (2007). Coal Tar-Containing Asphalt: Resource or Hazardous Waste? Journal of Industrial Ecology Volume 11, Number 4. http://dx.doi.org/10.1162/ jiec.2007.1106

Arm, M. (2007). Strength development in road layers of crushed concrete - Results from field tests". In: Jacobsen, Jahren och Kjellsen (Ed.), Int Conf on Sustainability in the Cement and Concrete industry. Lillehammer, Norway. pp 290-298.

Arm, M. (2010). SGI Linköping. Interview.

Anon. (2010). Applicability of End-of-waste concept for soil and rock waste material arising from earth construction. Memorandum funded by the Finnish Ministry of the Environment. Joint research project between the Finnish Environment Institute (SYKE) and VTT. 35 pages (in Finnish).

Baun, D.L. \& Hjelmar, O. (2003). Kortlægning afforurenende stoffer i byggeaffald. Laboratorie-undersøgelser. Input to Miljøprojekt Nr. 1083, 2006. Miljøstyrelsen, 2006. Produced by DHI, Hørsholm, Denmark.

Böhmer, S., Moser, G., Neubauer, C., Peltoniemi, M., Schachermayer, E., Tesar, M., Walter, B., \& Winter, B. (2008). AGGREGATES CASE STUDY, Final Report referring to contract $\mathrm{n}^{\circ}$ 150787-2007 F1SC-AT "Aggregates case study - data gathering" (study commissioned by JRC-IPTS), Vienna.

CEC (2003). Council Decision 2003/33/EC of 19 December 2002 establishing criteria and procedures for the acceptance of waste at landfills pursuant to Article 16 and Annex II to Directive 1999/31/EC.

Delgado, L., Catarino A.S., Eder, P., Litten, D., Luo, Z., Villanueva, A. (2009). End of Waste Criteria, final report. JRC Scientific and Technical Reports. European Commission, Joint Research Centre, Institute for Prospective Technological Studies, Seville, Spain.

DHI and ECN (2003). Development of acceptance criteria for landfilling. Documentation of the modelling and scenario calculation carried out by DHI and ECN in support of the development of acceptance criteria for landfilling within the TAC Subcommittee on the Landfill Directive. Draft report for the Danish EPA and the Dutch Ministry of the Environment.

DirectMat (2010). http://direct-mat.fehrl.org/index.php?m=1

DRI (2002). Ubundne bærelag af knust beton. Vejledning-Leveringsbetingelser-Almindelig arbejdsbeskrivelse. Vejteknisk Institut, Rapport 113, Roskilde.

DTCWR (2006). Potential economic and environmental effects in Denmark of potential changes to "end-of-waste" definitions. Report prepared by the Danish Topic Centre on Waste and Resources, Copenhagen. 
ECHA (2011). Guidance on requirements for substances in articles. Version 2, April 2011. ECHA-11-G-05-EN. European Chemicals Agency, Helsinki, Finland.

ECHA (2010). Guidance on waste and recovered substances. Version 2, May 2010. ECHA-10-G-07-EN. European Chemicals Agency, Helsinki, Finland.

EN 13286. Unbound and hydraulically bound mixtures - Test methods.

EN 13285. Unbound mixtures - Specifications.

Engelsen C.J., Hansen, E.A., \& Hansesveen, H. (2002). Miljøpåvirkning ved bruk av resirkulert tilslag. Project report, RESIBA (2002/03), Byggforsk, Oslo.

Engelsen C. J., Sæther D. H., Mehus J., Pade C. (2005). Carbon dioxide uptake in demolished and crushed concrete Nordic Innovation Center Project report 395.

Engfeldt C (2006). Aska från energiproduktion - producerad och använd mängd aska $i$ Sverige. Svenska EnergiAskor.

Engström H. \& Ulwan Å. (2005). Sluttäckning av avfallsdeponier ur ett nationellt perspektiv. Traditionella material eller restprodukter - miljömässiga och ekonomiska konsekvenser. Examensarbete UPTEC STS05 007, Uppsala Universitet.

Finnish Ministry of the Environment (2006). Government Decree concerning the recovery of certain wastes in earth construction (591/2006), 28.06.2006.

Grönholm Raul (2010). SYSAV Interview.

Hjelmar, O., Hansen, J.B., Wahlström, M. \& Wik, O. (2011). End-of-Waste Criteria for Construction and Demolition Waste, Report Phase 1 for Nordic Council of Ministers, DHI, Hørsholm, Denmark.

Hjelmar, O., Holm, J., Hansen, J.G., Dahlstrøm, K. (2005). The European criteria for acceptance of waste at landfills: Implementation of Council Decision 2003/33/EC in Denmark. In: Proceedings of the 1st International on Engineering for Waste Treatment, WasteEng 05, May 17-19, Albi, France, 2005.

Hjelmar, O., H.A. van der Sloot, D. Guyonnet, R.P.J.J. Rietra, A. Brun \& D. Hall (2001). Development of acceptance criteria for landfilling of waste: An approach based on impact modelling and scenario calculations. In: T.H. Christensen, R. Cossu and R. Stegmann (eds.): Sardinia 2001, Proceedings of the Eigth International Waste Management and Landfill Symposium, S. Margharita di Pula, Cagliari, CISA, Vol.III, pp. 712-721.

IPTS (2011). Personal communication.

IPTS (2009). Study on the selection of waste streams for End of Waste assessment. JRC Scientific and Technical Reports. European Commission, Joint Research Centre, Institute for Prospective Technological Studies, Seville, Spain.

Jernkontoret (2009). Stålindustrin gör mer än stål - Handbok för restprodukter.

Karlsen, J., Petkovic, G., \& Lahus 0. (2002). Forslag til deklarasjonsordning for resirkulert tilslag. Project report, RISIBA (2002/04), Byggforsk, Oslo.

KFA (2008). Kontrollordningen for Asfaltgjenvinning - Årsrapport 2008.

Lindelöf P. (2010). Malmö Gatukontoret Interview.

Löwegren N. (2010). Swedish Transport Administration Interview.

Makela, H. \& Hoynala, H. (2000). Sivutuotteet ja uusiomateriaalit maarakenteissa. Teknologia-katsaus 91/2000.

Miljøstyrelsen (2010a). Affaldsstrategi '10. Miljømininisteriet, Miljøstyrelsen, Copenhagen.

Miljøstyrelsen (2010b). Affaldsstatistik 2007 and 2008. Miljøministeriet, Miljøstyrelsen, Copenhagen. 
Miljøstyrelsen (2006). Problematiske stoffer I bygge- og anlægsaffald - kortlægning, prognose og bortskaffalsesmuligheder. Miljøprojekt nr. 1084. Miljøministeriet, Miljøstyrelsen.

Mroueh, U-M., Laine-Ylijoki, J. \& Wahlström, M. (2003). Development of a standardised quality control system for reclaimed concrete. WASCON 2003. Proceedings of the fifth international conference on the environmental and technical implication of construction with alternative materials, San Sebastian, 4-6 June 2003, eds. G. Ortiz de Urbana, J. Goumans. ISCOWA/INASMET, p. 441-448.

Myhre, Ø., Skaare, L., \& Mehus, J. (2003). Ubunden bruk av resirkulert tilslag i veger og plasser. Project report, RESIBA (2002/05), Byggforsk, Oslo.

Naturvårdsverket (2010). Återvinning av avfall i anlägningsarbeten. Handbok 2010:1, Stockholm.

Nordin, A. (2010). Swedish EPA Interview.

Norconsult (2010). Kartlegging av nyere fraksjoner av farlig avfall i bygg. Project report.

Norweigian Ministry of the Environment (2007-2008). The Government's Environmental Policy and the State of the Environment in Norway. Excerpts in English: Report No. 26 (2006-2007) to the Storting.

NS 3420. Beskrivelsestekster for byg, anlegg, installasjoner. Del I5 Fundamenter for veier, baner og plasser.

NS-EN 13242. Aggregates for unbound and hydraulically bound materials for use in civil engineering work and road construction.

NS-EN 13043. Aggregates for bituminous mixtures and surface treatments for roads, air-fields and other trafficked areas.

NS-EN 13620. Aggregates for concrete.

Petkovic, G. and Lillestøl, B. (2002). Materialegenskaper for resirkulert tilslag. Project report 2002, RESIBA (2002/02). Byggforsk, Oslo.Saarinen, E. (2010): Vanhojen kerrostalojen betoni uusiokayttoon. UUsiouutiset Vol 19 (2008) 7, 4-6.

SGI. (2006). Projektet Handböcker för alternativa material $i$ väg- och anläggningsbyggnad. SGI:s informationsserie Nr 18. Statens geotekniska institut, Linköping.

SGI (2007). Sammanställning av materialoch användningsområden. Underlag i Natur-vårdsverkets regeringsuppdrag, Återvinning av avfall i anläggningsarbeten. Varia 572.

SGU (2009). Aggregates, Production and resources 2008.

SMED (2009). Utvecklingsprojekt för byggavfall - Hur ska avfallsstatistik från byggsektorn tas fram på bästa sätt? Svenska MiljöEmissionsData www.smed.se.

SSM (2001). Celia Jones Karin Pers Radioaktivt avfall från icke tillståndsbunden verksamhet (RAKET) - identifiering av aktuellt avfall, sammanställning av relevanta regler och principer, förslag på system för omhändertagande, SSI report 2001:15.

SSM (2009). Nationell plan för allt radioaktivt avfall. Rapport 2009:29.

SSM (2010a). Pm - undantag för norm. Strålsäkerhetsmyndighetens föreskrifter om undantag $\mathrm{mm}$ för omhändertagande av NORM.

SSM (2010b). Förslag till föreskrifter och allmänna råd om naturligt förekommande radioaktivt material.

Statens Vegvesen (2005). Vegbygging, handbook 018.

Stockholm City Environment and Health Administration (2006). Materialsortering vid rivning och renovering.

Strauss, C.M. (2010). Email from Naturvårdsverket dated 15 October 2010.

Stripple, H. (2010). IVL Swedish Environmental Institute. 
Svensk Bergs- \& Brukstidning (2010). SBMI:s branschdag och årsmöte. Nr 3/2010

Swedish Association of Local Authorities and Regions (2004). På väg igen -vägen tillbaka för àtervunnen asfalt.

Swedish Association of Local Authorities and Regions (2008). Sopsand - Avfall eller resurs?: Hållbar hantering av halkbekämpningsmedel.

Swedish Rail administration (2002). Hantering av jordmassor ur avfalls- och föroreningssynpunkt. Banverkets handbok, BVH 585.85.

Swedish Road administration (2000). Provtagning, provning och bedömning av provningsresultat av asfaltmaterial för återvinning. VVMB 620, Publ. 2000:109.

Swedish Road administration. (2003). Hantering av tjärhaltiga beläggningar. VV publ 2003:90.

Swedish Road Administration (2004a). Allmän teknisk beskrivning. Krossad betong $i$ vägkonstruktioner. Publ 2004:11.

Swedish Road Administration (2004b). Handbok för återvinning av asphalt.

Swedish EPA (2006). A Strategy for Sustainable Waste Managements - Sweden's Waste Plan.

Swedish Road Administration (2007a). Alternativa material i väg- och järnvägsbyggnad 2007:110.

Swedish Road Administration (2007b). Hantering av uppgrävda massor - Administrativa krav 2007:99.

Swedish Road Administration (2007c). Hantering av vägdikesmassor - råd och rekommendationer Publ. 2007:101.

Swedish Road Administration (2007d). Råd och rekommendationer för hantering av sulfidjordsmassor 2007:100.

Swedish Road Administration (2008). Skötsel av öppna vägdagvattenan-läggningar Publ. 2008:30.

Swedish EPA (2010a). PM Prioriterade områden i planen. Dnr 190-6843-09 Rp.

Swedish EPA (2010b). http://www.naturvardsverket.se/sv/Produkter-och-avfall/Avfall/Hantering-och-behandling-av-avfall/Vagledning-for-hantering-och-tillsyn-av-bygg--och-rivningsavfall/

Swedish EPA (2010c). Återvinning av avfall i anläggningsarbeten Handbok 2010:1.

Swedish EPA (2010d). Waste in Sweden 2008 (Avfall i Sverige 2008). Report 6362.

Swedish Parliment (2010). Svenska miljömål. Miljö- och jordbruksutskottets betänkande 2009/10:MJU25.

TA-nummer 1853/2002. Bygg-og anleggsavfall: Disponering av rene naturlige masser og gjenvunnet materiale.

Tell, R. (2010). ÅGAB Malmö Interview.

The Ecocycle Council (2007). Avfallshantering vid byggande och rivning - Avfallshantering vid byggande och rivning - Kretsloppsrådets riktlinjer,

http://www.krets-loppsradet.com/web/page.aspx?pageid=170103

Toller S (2010). Ecoloop Interview.

Tyllgren P (2008). Handbok - Slaggrus för sammansatta obundna material i väg-och anläggningsbyggande. Värmeforsk Rapport Q6-606.

Vaivars A. (In press). Sustainable aggregate supply in Stockholm County. Master thesis KTH. 
Van der Sloot, H.A., Seignette, P., Comans, R.N.J., van Zomeren, A., Dijkstra, J.J., Meeussen, H., Kosson, D.D. \& Hjelmar, O. (2003): Environmental performance of waste materials. In: Dhir, R.K, Newlands, M.D. \& Halliday, J.E. (eds.): Recycling and Reuse of Waste Materials. Proceedings of the International Symposium held at University of Dundee, Scotland, UK on 9-11 September 2003, Thomas Thelford, London, pp. 769-789.

WHO (1996). Guidelines for drinking-water quality, 2. ed. Vol. 2: Health criteria and other supporting information. World Health Organisation, Geneva.

Wik, O., Lindeberg, J., Nilsson Påledal, S., Arm, M. \& Lind, B. (2003). Inventering av restprodukter som kan utgöra ersättningsmaterial för naturgrus och bergkross $i$ anläggningsbyggande. Statens geotekniska institut / Sveriges geologiska undersökning.

Wik, O., Larsson, L., Andersson-Sköld, Y., \& Jacobsson, T. (2005). Sammanställning av underlag till vägledning om hantering av tjärasfalt. Rapport daterad 2005-12-05. Statens geotekniska institut, unpublished.

Ydrevik, K. (1999). Återvägen - Råd och vägledning för krossad betong som ballast i gator och vägar. VTI-notat 67-1999. Swedish Road and Transport Research Institute. 



\section{Dansk resumé}

Affaldsrammedirektivet (WFD) 2008/98/EF åbner mulighed for at etablere såkaldte "End-of-Waste" (EoW) -kriterier, hvorved specifikke affaldsfraktioner kan omklassificeres til produkter og altså ophøre med at være affald, såfremt kriterierne overholdes. Som produkter vil materialerne i princippet kunne markedsføres til specifikke formål. Ifølge Artikel 6(1) i WFD vil et affaldsmateriale kunne ophøre med at være affald som defineret i WFD, når det har gennemgået en nyttiggørelsesoperation, herunder genanvendelse, er almindeligt anvendt til specifikke formål, har en markedsværdi, opfylder de tekniske krav til de specifikke formål og lever op til gældende lovgivning og normer vedrørende produkter. I tilgift skal der etableres kriterier, som sikrer, at anvendelsen af materialet ikke giver anledning til generelle negative indvirkninger på miljøet eller menneskers sundhed. Disse kriterier skal omfatte grænseværdier for forurenende stoffer, hvis det er nødvendigt, og skal beskytte mod alle mulige negative miljøeffekter fra materialet.

Når det er klassificeret som affald, vil de miljø- og sundhedsmæssige aspekter af anvendelse af bygge- og anlægsaffald (B\&A-affald) til anlægsformål være reguleret af affaldslovgivning på nationalt (og EU-)plan. Tekniske/funktionelle kriterier for anvendelse af B\&A-affald til anlægsformål er reguleret under Byggevareforordningen (Construction Products Regulation, CPR) af harmoniserede europæiske produktstandarder. Hvis en granulær B\&A-affaldstype opnår EoE-status og ikke længere er affald, bliver materialet til et produkt. I så fald vil det ikke længere være omfattet af affaldslovgivningen, og de miljø- og helbredsbeskyttende regler i denne lovgivning vil ikke længere gælde for materialet. I stedet vil anvendelsen af materialet alene være reguleret af produktlovgivningen. Et affaldsbaseret B\&A-materiale med EoW-status, som anvendes til bygge- og anlægsformål, vil være omfattet af CPR, men også af kemikalielovgivningen (REACH), dog muligvis undtaget fra visse reglerne heri. Anden EU- og national lovgivning kan også have en direkte eller indirekte indflydelse på betingelserne for anvendelse af B\&A-affald med EoW-status.

I øjeblikket (2012/2013) har ingen af de nordiske lande planer om at udnytte muligheden for etablering af nationale EoW-kriterier for B\&A-affald eller andre affaldstyper, og Danmark, Finland og Sverige udtrykker generelt betænkeligheder ved de miljø- og helbredsmæssige 
forhold, hvis der på EU-plan skulle blive udviklet EoW-kriterier for B\&Aaffald af Kommissionen.

Der genanvendes/nyttiggøres meget betydelige mængder B\&A-affald til bygge- og anlægsformål i Danmark, Finland, Norge og Sverige. I Danmark og Finland er anvendelsen af B\&A-affald underkastet specifik lovgivning, mens den i Norge og Sverige er styret af mere generelle regler. Hvert af de nordiske lande har deres egne funktionelle kriterier for anvendelse af granulært B\&A-affald til forskellige bygge- og anlægsformål. De fleste af disse funktionelle, fysiske specifikationer kan dog findes i de harmoniserede europæiske produktstandarder (hEN'er) for granulære materialer, som er udviklet af CEN.

Sikker håndtering og genanvendelse/nyttiggørelse af B\&A-affald har meget høj prioritet i både Danmark, Finland, Norge og Sverige, og adskillige undersøgelser og initiativer er blevet gennemført eller er under gennemførelse for at understøtte disse mål. Resultaterne af nogle af disse tiltag vil kunne indgå i en eventuel udvikling af EoW-kriterier for granulære B\&A-affaldsmaterialer, herunder specielt knust beton.

Danmark, Finland og Norge har etableret lister over de forurenende stoffer, som giver anledning til de største betænkeligheder med hensyn til håndtering, genanvendelse/nyttiggørelse og udvikling af EoW-kriterier, specielt for knust beton. Oprindelsen af disse stoffer vurderes at være nogenlunde den samme i alle tre lande. Stofferne omfatter: $\mathrm{Cd}, \mathrm{Cr}, \mathrm{Cu}, \mathrm{Hg}, \mathrm{Mo}$, $\mathrm{Ni}, \mathrm{Pb}, \mathrm{Sb}, \mathrm{Zn}, \mathrm{PCB}, \mathrm{PAH}$, brominerede flammehæmmere, chlorparaffiner, $\mathrm{CFC}, \mathrm{HCFC}, \mathrm{HFC}, \mathrm{SF}_{6}$, kulbrinter og phenoler. Fra et udvaskningssynspunkt kunne man også nævne sulfat fra gipsplader som et potentielt problem.

Adskillige pågående eller nyligt afsluttede projekter i de nordiske lande har haft til formål at øge både mængder og kvalitet af genanvendt B\&A-affald, herunder knust beton, og at reducere potentielle miljø- og helbredspåvirkninger.

De nordiske lande har en speciel interesse i at beskytte kvaliteten af grundvand og overfladevand. I Danmark består næsten alt drikkevand af grundvand, som bruges uden behandling (bortset fra beluftning og filtrering), og beskyttelse af grundvand mod forurening har derfor høj prioritet. Grundvandskvaliteten er allerede truet af stigende diffuse forureninger af overfladejord og fra anvendelse af pesticider og kunstgødning. Det er derfor vigtigt at kontrollere og begrænse nye potentielle kilder til grundvandsforurening. I Finland, Norge og Sverige kommer meget af drikkevandet fra søer og vandløb, som indgår i økosystemer, der er sårbare overfor forurening med såvel organiske som uorganiske stoffer, og beskyttelse af kvaliteten af overfladevand har derfor specielt høj prioritet i disse lande. Et andet specifikt nordisk aspekt er den forholdsvis høje 
nedbørsmængde i regionen, som kan give anledning til en stor udvaskning af granulære materialer anvendt til bygge- og anlægsformål. De lave temperaturer, som kan forekomme om vinteren i store dele af den nordiske region kan også medføre en forholdsvis stor grad af forvitring som følge af skiftende frost og tø og resultere i øget eksponering af B\&A-affald i bundne (støbte) anvendelser, f.eks. som tilslag i beton. Hvis og når der skal opstilles kriterier for anvendelse af B\&A-affald og andre granulære materialer som affaldsmaterialer eller som produkter med EoW-status, bør disse forhold tages i betragtning.

Dette projekt fokuserer primært på etablering af grænseværdier for stofudvaskning i forbindelse med opnåelse af EoW-status med henblik på beskyttelse af grundvand, overfladevand og jord mod forurenende stoffer, som vil kunne frigives fra B\&A-affald ved udvaskning. Beskyttelse af mennesker mod eksponering for skadelige stoffer gennem inhalering, indtagelse, direkte kontakt og ophold i arbejdsmiljøet er lige så vigtig, men det kan antages, at den eksisterende lovgivning og/eller vejledning $\mathrm{i}$ de nordiske lande vedrørende maksimale indhold af (farlige) stoffer kan adapteres og tjene som EoW-kriterier på dette område. EoW-kriterierne bør derfor omfatte grænseværdier både for stofudvaskning og totalindhold af relevante stoffer.

Det foreslås, at alle risikovurderinger, der anvendes til udvikling af EoW-kriterier, herunder grænseværdier for stofudvaskning, baseres på den velkendte kildestyrke-transport-receptor-kæde.

Hvis der ikke indgår nogen restriktioner eller betingelser for anvendelsen af affaldsbaserede granulære materialer, der har opnået EoW-status, vil det være nødvendigt at tage højde for dette ved fastlæggelsen af de miljø- og helbredsmæssige kriterier, som skal opfyldes, dvs. de må baseres på forholdsvis konservative (om ikke worst-case) anvendelsesscenarier. Hvis receptoren er grundvand eller overfladevand, fører dette til udvaskningskriterier for opnåelse af EoW-status, som er så restriktive, at stort set ingen fraktioner af B\&A-affald vil kunne opfylde dem. Disse grænseværdier er op til 960 gange lavere end EU-grænseværdierne for stofudvaskning fra inert affald, som ønskes deponeret.

Det anbefales derfor, at der, hvis der skal udvikles EoW-kriterier for granulært B\&A-affald, fastsættes betingelser for anvendelsen med henblik på at reducere den potentielle påvirkning af miljøet og menneskers helbred. Sådanne betingelser kunne for eksempel omfatte, at materialet kun kan anvendes til nærmere specificerede formål, at materialet skal fjernes, når det ikke længere opfylder det tiltænkte formål, minimumsafstand til overfladevand og drikkevandsboringer, minimumsafstand til 
overfladen af grundvand, restriktioner på højde, bredde og længde af anvendelsesprojekter, restriktioner på den maksimale årlige infiltration af nedbør. Sådanne betingelser kan reducere både påvirkningen af omgivelserne som følge af stofudvaskning og eventuelle risici forbundet med direkte kontakt med materialet.

Det anbefales endvidere, at der anvendes en veletableret og anerkendt metode baseret på en trinvis procedure til udvikling af udvaskningsgrænseværdier for opnåelse af EoW-status (eller til brug i forbindelse med regulering under affaldsbaseret lovgivning). Trinene i denne procedure er:

- Trin 1: Beskrivelse af anvendelsesformen og de betingelser, som skal gælde for anvendelsen.

- Trin 2: Beskrivelse af den eller de relevante receptor(er) og de primære vandkvalitetskriterier.

- Trin 3: Beskrivelse og modellering af kildestyrken.

- Trin 4: Beskrivelse og modellering af stoftransporten fra kilden til referencepunktet (POC).

- Trin 5: Vurdering af påvirkningen ved POC i receptoren og "baglæns" modellering eller iteration til tilpasning af kildestyrken til de primære vandkvalitetskriterier.

- Trin 6: Transformation af kildestyrken til specifikke grænseværdier svarende til en eller flere udvaskningstests.

- Trin 7: Vurdering af de resulterende grænseværdier og eventuel gentagelse af den trinvise procedure under ændrede betingelser.

- Trin 8: Inddragelse af andre overvejelser med henblik på eventuelle modifikationer af relativt høje (eller lave) grænseværdier for nogle stoffer.

Denne metodologi er baseret på de samme principper, som blev anvendt ved udviklingen og beregningen af EU's udvaskningsbaserede grænseværdier for modtagelse af affald til deponering. Metoden er også blevet officielt anvendt i Danmark og Sverige.

Metodologien er blevet demonstreret for fire forskellige eksempler på anvendelsesscenarier for B\&A-affald. Nogle af de resulterende grænseværdier er relativt høje (højere end EU's grænseværdier for inert affald til deponering), og det anbefales derfor, at en række andre forhold også tages i betragtning. Nogle af disse forhold kunne være: 
- Et ønske om ikke at skabe et antal potentielle affaldsdeponier (det kunne være et krav, at grænseværdierne for stofudvaskning (eller stofindhold) ikke må overstige de tilsvarende EU-grænseværdier for modtagelse af affald på deponeringsanlæg for inert affald eller deponeringsanlæg for ikke-farligt affald, der modtager stabilt, ikkereaktivt farligt affald.

- Et ønske om ikke at have EoW-grænseværdier, som er højere end eller endda blot lig med nationale grænseværdier for anvendelse af affaldsmaterialer eller jord til bygge- og anlægsformål (tilpasning kan være nødvendig, selv om betingelserne kan være forskellige).

- Risikoen for at et stof, som har en høj grænseværdi på grund af en lille påvirkning ved POC, kan påvirke udvaskningen af andre stoffer og for eksempel øge deres opløselighed og udvaskning. Dette kunne for eksempel være tilfældet ved høje koncentrationer af DOC, chlorid og sulfat.

- Risikoen for, at nogle stoffer kan skade bygværker eller processer (højere koncentrationer af sulfat kan for eksempel give anledning til korrosion af beton, og hvis der er bionedbrydeligt materiale til stede, kan der dannes giftig og ildelugtende svovlbrinte). Dette kan i nogle sammenhænge give anledning til reduktion af en beregnet grænseværdi for udvaskning af sulfat.

Der er foreslået og beskrevet en systematik, som i forbindelse med udvikling af EoW-kriterier for B\&A-affald omfatter bestemmelse af såvel stofudvaskning som stofindhold samt opbygning af et dossier til dokumentation af materialets egenskaber.

Endelig er der givet nogle anbefalinger vedrørende krav til input-materialer og forbehandling af B\&A-affald (knust beton). Det foreslås, at der gennemføres en stringent kontrol af kvaliteten af input-materialerne. De nordiske lande (Danmark, Finland, Norge og Sverige) har allerede procedurer for selektiv nedrivning og dekontaminering af bygninger og on-sitesortering af B\&A-affald/beton, som, hvis de opfyldes, og der foretages inspektion i fornødent omfang, sandsynligvis vil være tilstrækkelige til sikre en god kvalitet af input-materialerne. Sådanne procedurer kan, hvis de følges nøje, effektivt reducere forureningen af knust beton med udefra kommende stoffer (andre materialer såsom asbest, isoleringsmateriale og gipsplader, maling, diffunderende stoffer (PCB, Hg)), men ikke stoffer, som stammer fra betonen selv (for eksempel råmaterialer, herunder kulflyveaske, formolier og mange andre stoffer, som tilsættes under produktion og udstøbning af cement og beton). Projekter med det formål at forbedre nedrivnings- og renovationsprocedurer og sikre en høj kvalitet af 
B\&A-affald men det lavest mulige risiko for uacceptabel forurening er nyligt gennemført i Danmark, og anbefalinger af eventuelle nye procedurer forventes at inddrage resultaterne af disse projekter.

De procedurer, som er foreslået af EU-Kommissionens fælles forskningscenter, Institute for Prospective Technology Studies ved JRC (Delgado et al., 2009) for B\&A-affald (en kontrolleret selektiv nedrivningsprocedure) kan være anvendelige - i sammenhæng med EoW-kriterier for indhold og udvaskning af relevante stoffer, med den væsentlige tilføjelse at rutinemæssig kontrol på produktionsstedet og overensstemmelsestestning på regelmæssig basis vil være påkrævet for produkter bestående af knust beton baseret på alle kategorier af input-materialer for at sikre, at de etablerede EoW-grænseværdier for indhold og udvaskning af potentielt skadelige stoffer overholdes. Procedurerne bør beskrives meget mere detaljeret, og både vejledninger og stringente kontrolprocedurer vil være påkrævet.

De tekniske krav til indhold af urenheder i produktstandarder og vejledninger (f.eks. i forbindelse med anvendelse til vejbygning) bør gennemgås og eventuelt revideres. Behovet for krav til sortering og knusningsprocedurer bør overvejes. Det bør specielt tilstræbes, at for eksempel PCB-holdigt affald og gipsplader holdes ude af produktstrømmen, hvis de ikke er fjernet allerede i forbindelse med den selektive nedrivning eller udsorteret på bygge- eller nedrivningspladser. 


\title{
Appendix 1: Management of C\&D waste in Denmark
}

\author{
Management of C\&D waste as aggregates in Denmark
}

\section{Strategic initiatives regarding C\&D waste}

C\&D waste is identified as a high priority waste stream in the Danish government's current waste management strategy (Danish EPA, 2010a) and in the Governments Action Plan for handling PCB in Buildings - Indoor climate, Working environment and Waste (May 2011).

The aim of the waste management strategy is to improve the quality of the recycling of $C \& D$ waste and to ensure that the content in and release of harmful substances, in particular PCB, from recycled C\&D waste are low and does not exceed acceptable levels. Efforts are planned to assess the feasibility of setting criteria for the content and leaching properties of C\&D waste to be recycled, to point out which materials are likely to contain PCB, and to ensure that PCB-containing C\&D waste is managed correctly.

Four projects have been initiated in order to ensure that as much as possible of the PCB-containing waste already during the demolition and renovation phase can be separated from the $C \& D$ waste that is processed to be recycled.

The objective of the first of these projects is to develop a general limit value for PCB in C\&D waste that is low enough to ensure that the waste can be considered unpolluted by PCB and hence suited for recycling.

The second project is aimed at the collection of information and development of guidance on how to recognise materials that may contain PCB during renovation and demolition and thereby facilitating removal and correct handling of PCB-containing waste. It is also an objective to collect existing knowledge on the spreading of PCB from joints into the concrete in preparation of a guideline on removal of concrete contaminated with PCB.

The third project shall establish a formalised, coordinated inventory and registration system in connection with renovation and demolition of certain buildings. This will ensure that builders and contractors identify the presence of PCB in a building and that the regulatory requirements on occupational health and waste management can be fulfilled. 
A fourth initiative will be taken to carry out stakeholder discussions of educational requirements and certification in order to ensure that selective demolition of larger buildings can be carried out properly.

In addition to this, a study has been initiated to describe the content and release of dangerous substances from two types of C\&D waste, crushed concrete and tiles, in preparation of the development of quality criteria for C\&D waste to be recycled.

\section{Regulation of C\&D waste and other waste aggregates}

Spreading or burying waste requires a specific permit under the Environmental Protection Act. This also applies to C\&D waste and other types of aggregates. However, some fractions of non-hazardous unpolluted C\&D and certain other types of aggregates can be used as a substitute for primary raw materials without a specific permit under the Environmental Protection Act - provided the requirements of Statutory Order no. 1662 of 21 December 2010 are met.

Asphalt waste can be used for road building purposes etc. without a specific permit under the Environmental Protection Act - provided the requirements the Asphalt Circular of 15 July 1985 are met.

\section{Requirement for on-site sorting of C\&D waste}

C\&D waste for recycling must be sorted on-site and as a minimum be sorted into the following fractions:

- Natural stones, e.g. granite and flint.

- Non-glazed tiles (bricks and roof tiles).

- Concrete.

- Mixtures of stone materials, non-glazed tiles and concrete.

- Iron and metal.

- Gypsum.

- Stone-wool.

- Soil.

- Asphalt. 
When sorting at the source of fractions 1 to 4 it must be ensured that all other than mortar and possibly reinforcement iron has been removed and handled separately, and that PCB containing sealant materials have been identified, removed and handled separately. Sorting on-site may be omitted if the total amount of waste from the construction and demolition operation in question is less than 1 tonne or if the physical conditions render on-site sorting impossible. In those cases sorting may take place at a stationary sorting facility approved by the municipality. Sealed glazing units (windows) not suited for recycling or reuse must be destructed or landfilled.

The local councils shall lay down regulations for handling municipal C\&D waste and through inspections ensure compliance with the Statutory Order.

\section{Requirements for use of C\&D waste}

\section{Statutory Order no. 1662 of 21 December 2010 on use of residual products and soil in building and construction work and on use of sorted, unpolluted C\&D waste}

Statutory Order no. 1415 of 12 December 2011 on waste lays down requirements on sorting and recycling of C\&D waste in Denmark with the aim to reduce the amount of waste to be landfilled or incinerated and to reduce the use of virgin raw materials. The Statutory order does not include sorting and recycling of hazardous waste, contaminated soil, gravel, etc. and waste subject to special rules in other legislation.

Uncontaminated $^{11} \mathrm{C} \& \mathrm{D}$ waste that have been sorted in accordance with Statutory Order no. 1415 of 12 December 2011 and belonging to fractions 1 to 7 on the list above may without permission be prepared for reuse for the same or similar purposes as those the waste materials were previously used for, including reuse of bricks, tiles or gypsum plates in house building. Uncontaminated C\&D waste may be stored on-site for up to 1 year without permission. Uncontaminated C\&D waste of fractions 1 to 4 may without permission and after treatment be used as a replacement of virgin raw materials (this requires that a declaration is filed with the municipality at least two weeks prior to the use, specifying where,

\footnotetext{
11 In Statutory Order no. 1662 of 21 December 2010, uncontaminated C\&D waste is defined as C\&D waste for which it with a high degree of certainty can be assumed that the waste does not contain polluting materials or substances to such an extent or of such a nature and concentration that the use of the waste may have an adverse impact on the environment or human health. The waste must hence not contain polluting substances, including substances that can cause contaminating release to soil or groundwater, including e.g. impregnated wood, PCB containing sealants, tar, soot, remains of paint and lacquer.
} 
when, what type and how much C\&D waste will be used). Other types of recycling of C\&D waste than those just mentioned can only take place in accordance with other regulation in the Environmental Protection Act. So far, no environmental testing have been required for C\&D waste to be used, but this is like to change as a result of the above mentioned initiatives taken by the Danish Environmental Protection Agency.

\section{Requirements for use of asphalt}

A circular on the use of recovered and crushed asphalt in road construction and similar applications issued by the Danish EPA in July 1985 and a corresponding interpretive note state that crushed asphalt may be recycled without permission for use as sub-base and consolidation of the surface of roads, paths, parking lots even if they do not have an "impermeable" top cover. Layers of up to $1 \mathrm{~m}$ are foreseen, but if the crushed asphalt is used only for stabilising purposes, the thickness of the layer must not exceed $50 \mathrm{~cm}$. The criteria for use of asphalt is currently under review.

\section{Requirements for use of slag and other aggregates}

Statutory Order no. 1662 of 21 December 2010 sets quantitative criteria for the use of certain residual products and for slightly polluted soils.

Residual products (including MSWI bottom ash, coal fly ash and coal bottom ash) and slightly polluted soil to be used as replacement of primary raw materials in certain construction projects must fulfil quantitative criteria regarding the content and leachability of specified inorganic substances. In addition, the content of total organic carbon (TOC) in MSWI bottom ash must not exceed $3 \%(\mathrm{w} / \mathrm{w})$. Since soil contaminated with organic substances (as well as soil polluted with other inorganic substances than those mentioned in Table 10) are excluded from recycling and since most polluted soils are contaminated with organic substances, the Statutory Order has had very limited practical application to soil so far.

Statutory Order no. 1662/2010 distinguishes between three different categories of residual materials and soil, based on the results of a determination of the content of some trace elements (after partial digestion with $7 \mathrm{M}$ nitric acid) and on the results of a leaching test. The prescribed leaching test is, EN 12457-1, a batch leaching test performed at L/S $=2 \mathrm{l} / \mathrm{kg}$ with a contact time of 24 hours. The combined criteria for content and leached amounts which define the three categories are shown in Table 10.

It is specified for each type of residue for which of the substances in Table 10 limit values are relevant. 
Residues (and soil) falling in Category 1 may be used for certain specified purposes, i.e. construction of roads, paths, squares/parking lots, noise reduction walls, ramps, dikes, dams, railway embankments, pipe/cable trenches, landscaping, marine constructions, refilling floors and foundations without permit. Category 2 and Category 3 residues/soil may be recycled without permit under increasingly more stringent conditions concerning type of application, thickness and top cover (see the Table 9 below):

Table 9: Conditions of use for residual products (not including B\&A waste) in Danish Statutory Order no. 1662/2010

\begin{tabular}{|c|c|c|}
\hline Construction work & Category 2 & Category 3 \\
\hline Roads & Cover, max height $1 \mathrm{~m}$ & $\begin{array}{l}\text { Tight cover, max height } 1 \mathrm{~m} \text {, } \\
\text { surface water removal }\end{array}$ \\
\hline Paths & Cover, max height $0.3 \mathrm{~m}$ & Cover, max height $0.3 \mathrm{~m}$ \\
\hline Squares/parking lots & Cover, max height $1 \mathrm{~m}$ & \\
\hline Pipe/cable trenches & Cover & Cover \\
\hline Ramps & $\begin{array}{l}\text { Cover, max height } 4 \mathrm{~m} \text {, at least a } \\
150 / 00 \text { slope along the ramp }\end{array}$ & \\
\hline Noice reduction walls & $\begin{array}{l}\text { Cover, max height } 5 \mathrm{~m} \text {, max } 2 \mathrm{~m} \\
\text { wide on top, } 6 \mathrm{~m} \text { wide at bottom, } \\
\text { erosion protection required }\end{array}$ & \\
\hline $\begin{array}{l}\text { Foundations and floors below } \\
\text { buildings }\end{array}$ & $\begin{array}{l}\text { Max height } 1 \mathrm{~m} \text {, soil must not give } \\
\text { rise to indoor air problems }\end{array}$ & $\begin{array}{l}\text { Max height } 1 \mathrm{~m} \text {, soil must not give } \\
\text { rise to indoor air problems }\end{array}$ \\
\hline
\end{tabular}

Note: Cover: Asphalt, concrete, flagstones or $\min .1 \mathrm{~m}$ of Category 1 soil or similar, protecting against contact.

Tight cover: asphalt, concrete or similar, reducing the rate of infiltration of precipitation. Removal of surface run-off water shall reduce the infiltration to $\max 10 \%$ of the precipitation.

No later than 4 weeks prior to the intended start of the recycling project the user must submit a notification to the municipality detailing the location of the project, the start and end dates of the project, the amount, type and category of residue or soil to be used, the dimensions of the project (including drawings), an area situation plan showing the involved land register numbers, the location relative to drinking water borings and extraction wells, rivers, lakes and the sea, and information on whether or not direct discharges or indirect discharges via drainage systems to rivers, lakes or the sea will occur. The municipal authorities may, if there is a risk that the project will cause environmental pollution, within 4 weeks 
after receiving the notification, determine that the project shall be delayed until the impact on the environment has been studied or assessed. The municipal authorities will prohibit the project if it does not comply with regulatory requirements.

The limit values on content are based on toxicological considerations whereas the limit values on leaching are based on a risk assessment scenario (modelling the impact of a constant source on a groundwater extraction well placed $30 \mathrm{~m}$ downstream of the application and not taking sorption into consideration).

Table 10: Limit values for content and leached amounts in Statutory Order 1662/2010

\begin{tabular}{|c|c|c|c|}
\hline Substance & Category 1 & Category 2 & Category 3 \\
\hline \multicolumn{4}{|c|}{ Solid content in $\mathrm{mg} / \mathrm{kg}$ dry matter } \\
\hline As & $\leq 20$ & $>20$ & $>20$ \\
\hline$C d$ & $\leq 0.5$ & $>0.5$ & $>0.5$ \\
\hline $\mathrm{Cr}$ (total) & $\leq 500$ & $>500$ & $>500$ \\
\hline $\mathrm{Cr}(\mathrm{VI})$ & $\leq 20$ & $>20$ & $>20$ \\
\hline $\mathrm{Cu}$ & $\leq 500$ & $>500$ & $>500$ \\
\hline $\mathrm{Hg}$ & $\leq 1$ & $>1$ & $>1$ \\
\hline $\mathrm{Ni}$ & $\leq 30$ & $>30$ & $>30$ \\
\hline $\mathrm{Pb}$ & $\leq 40$ & $>40$ & $>40$ \\
\hline $\mathrm{Zn}$ & $\leq 500$ & $>500$ & $>500$ \\
\hline \multicolumn{4}{|c|}{ Leached amounts at $\mathrm{L} / \mathrm{S}=2 \mathrm{l} / \mathrm{kg}$ in $\mathrm{mg} / \mathrm{kg}$} \\
\hline As & $\leq 0.016$ & $\leq 0.016$ & $0.016-0.10$ \\
\hline $\mathrm{Ba}$ & $\leq 0.60$ & $\leq 0.60$ & $0.60-8.0$ \\
\hline$C d$ & $\leq 0.004$ & $\leq 0.004$ & $0.004-0.080$ \\
\hline $\mathrm{Cr}$ (total) & $\leq 0.020$ & $\leq 0.020$ & $0.020-1.0$ \\
\hline $\mathrm{Cu}$ & $\leq 0.090$ & $\leq 0.090$ & $0.090-4.0$ \\
\hline $\mathrm{Hg}$ & $\leq 0.0002$ & $\leq 0.0002$ & $0.0002-0.002$ \\
\hline $\mathrm{Mn}$ & $\leq 0.30$ & $\leq 0.30$ & $0.30-2.0$ \\
\hline $\mathrm{Ni}$ & $\leq 0.020$ & $\leq 0.020$ & $0.020-0.14$ \\
\hline $\mathrm{Pb}$ & $\leq 0.020$ & $\leq 0.020$ & $0.02-0.20$ \\
\hline Se & $\leq 0.020$ & $\leq 0.020$ & $0.020-0.060$ \\
\hline $\mathrm{Zn}$ & $\leq 0.20$ & $\leq 0.20$ & $0.20-3.0$ \\
\hline Chloride & $\leq 300$ & $\leq 300$ & $300-6000$ \\
\hline Sulphate & $\leq 500$ & $\leq 500$ & $500-8000$ \\
\hline Sodium & $\leq 200$ & $\leq 200$ & $200-3000$ \\
\hline
\end{tabular}

12 For MSWI bottom ash, there is an exemption for chloride, sulphate and sodium for category 2, setting "temporary" limit values of $3,000 \mathrm{mg} / \mathrm{kg}, 4,000 \mathrm{mg} / \mathrm{kg}$ and 2,000 mg/kg, respectively. 


\section{Requirement on landfilling of C\&D waste}

The EU Council Decision 2003/33/EC establishing criteria and procedures for the acceptance of waste at landfills pursuant to Article 16 of and Annex II to Directive 1999/31/EC sets limit values on content of certain organics and the leaching of mainly inorganic substances for acceptance of waste at e.g. landfills for inert waste. The Council Decision was implemented in Denmark in 2009 in Statutory Order No 719 of 24 June 2011 (now No. 1049 of 30 August 2013) on landfills which sets limit values on the content of TOC, BTEX, PCBs, hydrocarbons and PAHs and on the leaching of As, $\mathrm{Ba}, \mathrm{Cd}, \mathrm{Cr}$, $\mathrm{Cu}, \mathrm{Hg}, \mathrm{Mo}, \mathrm{Ni}, \mathrm{Pb}, \mathrm{Sb}, \mathrm{Se}, \mathrm{Zn}$, chloride, fluoride, sulphate, phenol (index) and DOC for waste to be landfilled at inert waste landfills.

\section{Production and use of C\&D waste in Denmark}

\section{Production of C\&D waste}

The production of C\&D waste in Denmark during the period 2006 to 2008 is shown in Table 11. From the point of view of crushing and recycling as aggregates, it is mainly the fractions concrete, (unglazed) tiles and asphalt - and mixtures of these - that are of interest.

According to Danish EPA (2010b) 95\% of the total stream of C\&D waste were recycled during each of the years 2006, 2007 and 2008. It is further stated that the high level of recycling is due to the fact that a circular on municipal rules concerning sorting of C\&D waste with the aim of recycling was issued in 1995, and that the Ministry of the Environment and the Constructors' Society have made an agreement on selective demolition of buildings. The same source mentions that a substantial amount of the C\&D waste is treated by mobile crushing plants that are moved from site to site.

Table 11: C\&D waste produced in Denmark split into fractions

\begin{tabular}{|c|c|c|c|}
\hline Fraction & 2006 (tonnes) & 2007 (tonnes) & 2008 (tonnes) \\
\hline Not suited for incineration & 153,668 & 123,949 & 105,866 \\
\hline Concrete & $1,392,609$ & $1,568,950$ & $1,451,830$ \\
\hline Tiles & 289,795 & 331,858 & 220,562 \\
\hline Other C\&D waste & 491,844 & 481,704 & 734,057 \\
\hline Asphalt & 965,161 & 781,217 & 883,570 \\
\hline Soil and rocks & $2,245,078$ & $1,725,739$ & $1,961,028$ \\
\hline Other recyclable & 232,864 & 400,562 & 229,636 \\
\hline Other & 341,639 & 352,747 & 422,242 \\
\hline Total: & $6,112,658$ & $5,766,726$ & $6,008,791$ \\
\hline
\end{tabular}

Source: Danish EPA, 2010. 
Despite the fact that nearly all concrete and tiles is recycled, they constitute only $5 \%$ of the total demand for gravel and stones in Denmark (DTCWR, 2006).

\section{Treatment of C\&D waste}

A treatment plant for production of recyclable aggregate fractions from C\&D waste typically consists of crushing and sorting (sieving) operations, sometimes also with manual quality control and sorting/removing operations inserted. Magnetic separators may also be included. The commonly produced fractions include crushed concrete $(0 / 32 \mathrm{~mm})$, a mixture of crushed concrete and tiles $(0 / 32 \mathrm{~mm})$, crushed tiles $(0 / 32 \mathrm{~mm})$, a mixture of crushed concrete and asphalt $(0 / 32 \mathrm{~mm})$ to be used as replacements for gravel in unbound applications in road construction, crushed concrete $(4 / 32 \mathrm{~mm})$ and crushed tiles $(4 / 32 \mathrm{~mm})$ to be used in hydraulically bound applications, mixtures of crushed concrete and asphalt $(0 / 32 \mathrm{~mm})$ and asphalt $(0 / 32 \mathrm{~mm})$. Larger fractions of crushed concrete $(32 / 70 \mathrm{~mm})$ may also be produced.

\section{Danish studies regarding C\&D waste}

Available data on leaching and content of various substances in Danish C\&D waste are reviewed below. In 2003, 15 samples of C\&D waste were collected from 6 stationary treatment plants in Denmark and tested for (partial) content of $\mathrm{As}, \mathrm{Cd}, \mathrm{Cr}, \mathrm{Cu}, \mathrm{Ni}, \mathrm{Pb}, \mathrm{Zn}$ and $\mathrm{Hg}$ and content of hydrocarbons, PAHs and PCBs. 7 of the samples were further tested for leaching of inorganics (chloride, sulphate, $\mathrm{Ca}, \mathrm{Na}, \mathrm{As}, \mathrm{Ba}, \mathrm{Cd}, \mathrm{Cr}, \mathrm{Cu}, \mathrm{Hg}, \mathrm{Mn}, \mathrm{Ni}, \mathrm{Pb}$ and $\mathrm{Zn}$ ) in a batch test (stage one of EN-12457-3) at L/S = $2 \mathrm{l} / \mathrm{kg}$ and leaching of organic substances (hydrocarbons, PAHs and PCBs) in an equilibrium column test at $\mathrm{L} / \mathrm{S}=$ approximately $1 \mathrm{l} / \mathrm{kg}$. The $\mathrm{C} \& \mathrm{D}$ fractions analysed for content were (Baun et al., 2003):

- 6 samples of crushed concrete $(0 / 32 \mathrm{~mm})$.

- 1 sample of crushed concrete $(32 / 70 \mathrm{~mm})$.

- 3 samples of crushed concrete and tiles $(0 / 32 \mathrm{~mm})$.

- 1 sample of tiles $(0 / 32 \mathrm{~mm})$.

- 2 samples of crushed concrete and asphalt $(0 / 32 \mathrm{~mm})$.

- 2 samples of asphalt $(0 / 32 \mathrm{~mm})$. 
The samples were size reduced to $0.125 \mathrm{~mm}$ prior to chemical analysis and to $<4 \mathrm{~mm}$ prior to the leaching tests.

The results of the analyses of the contents of inorganic and organic substance are presented in Tables 12 to 15.

Table 12: Content of trace elements in concrete fractions of C\&D waste determined after nitric acid digestion in accordance with DS 259

\begin{tabular}{|c|c|c|c|c|c|c|c|c|}
\hline \multirow{2}{*}{\multicolumn{2}{|c|}{$\begin{array}{l}\text { Waste type } \\
\text { Plant }\end{array}$}} & \multicolumn{6}{|c|}{ Pure concrete $0 / 32$} & \multirow{2}{*}{$\begin{array}{r}\text { Pure concrete } 32 / 70 \\
\text { Plant } 4\end{array}$} \\
\hline & & Plant 1 & Plant 2 & Plant 3 & Plant 4 & Plant 5 & Plant 6 & \\
\hline \multicolumn{2}{|c|}{ Sample ID } & GA-1-B & GA-2-B & GA-3-B & GA-4-B & GA-5-B & GA-6-B & GA-4-B2 \\
\hline $\mathrm{Ni}$ & $\mathrm{mg} / \mathrm{kg} \mathrm{TS}$ & 11 & 9.6 & 11 & 12 & 7.9 & 10 & 11 \\
\hline As & $\mathrm{mg} / \mathrm{kg}$ TS & 3 & 2 & 5.7 & 5 & 2.2 & 2.5 & 5.6 \\
\hline $\mathrm{Pb}$ & $\mathrm{mg} / \mathrm{kg} \mathrm{TS}$ & 11 & 11 & 6.4 & 9.2 & 6.5 & 17.0 & 11 \\
\hline $\mathrm{Cd}$ & $\mathrm{mg} / \mathrm{kg}$ TS & 0.19 & 0.22 & 0.1 & 0.2 & 0.14 & 0.15 & 0.23 \\
\hline $\mathrm{Cr}$ & $\mathrm{mg} / \mathrm{kg}$ TS & 15 & 15 & 17 & 16 & 10 & 14 & 24 \\
\hline $\mathrm{Cu}$ & $\mathrm{mg} / \mathrm{kg} \mathrm{TS}$ & 20 & 17 & 37 & 45 & 16 & 18 & 24 \\
\hline $\mathrm{Hg}$ & $\mathrm{mg} / \mathrm{kg}$ TS & 0.2 & 0.12 & 0.3 & 0.18 & 0.43 & 0.03 & 0.22 \\
\hline $\mathrm{Zn}$ & $\mathrm{mg} / \mathrm{kg} \mathrm{TS}$ & 49 & 45 & 58 & 61 & 31 & 56 & 61 \\
\hline
\end{tabular}

Source: Baun et al., 2003.

Table 13: Content of trace elements in concrete/tile, tile, concrete/asphalt and asphalt fractions of C\&D waste determined after nitric acid digestion in accordance with DS 259

\begin{tabular}{|c|c|c|c|c|c|c|c|}
\hline \multicolumn{2}{|c|}{ Waste type } & \multicolumn{3}{|c|}{$\begin{array}{c}\text { Concrete/tile } \\
0 / 32\end{array}$} & \multirow{2}{*}{$\begin{array}{l}\text { Pure tile } \\
0 / 32 \\
\text { Plant } 5\end{array}$} & \multirow{2}{*}{$\begin{array}{c}\text { Concrete/asphalt } \\
0 / 32 \\
\text { Plant } 6\end{array}$} & \multirow{2}{*}{$\begin{array}{l}\text { Pure asphalt } \\
0 / 32 \\
\text { Plant } 6\end{array}$} \\
\hline Plar & & Plant 1 & Plant 2 & Plant 3 & & & \\
\hline Sam & ID & GA-1-BT & GA-2-BT & GA-3-BT & GA-5-T & GA-6-BA & GA-6-A \\
\hline $\mathrm{Ni}$ & $\mathrm{mg} / \mathrm{kg}$ TS & 11 & 13 & 15 & 15 & 7.5 & 8.7 \\
\hline As & $\mathrm{mg} / \mathrm{kg}$ TS & 3.4 & 4 & 4 & 3.7 & $<2.0$ & 2.0 \\
\hline $\mathrm{Pb}$ & $\mathrm{mg} / \mathrm{kg}$ TS & 40 & 70 & 91 & 38 & 15 & 13 \\
\hline $\mathrm{Cd}$ & $\mathrm{mg} / \mathrm{kg}$ TS & 0.26 & 0.72 & 0.33 & 0.23 & 0.14 & 16 \\
\hline $\mathrm{Cr}$ & $\mathrm{mg} / \mathrm{kg}$ TS & 16 & 17 & 17 & 22 & 26 & 8.7 \\
\hline $\mathrm{Cu}$ & $\mathrm{mg} / \mathrm{kg}$ TS & 31 & 24 & 53 & 23 & 10 & 21 \\
\hline $\mathrm{Hg}$ & $\mathrm{mg} / \mathrm{kg}$ TS & 0.24 & 0.24 & 0.2 & 0.25 & 0.047 & 0.071 \\
\hline $\mathrm{Zn}$ & $\mathrm{mg} / \mathrm{kg} \mathrm{TS}$ & 120 & 110 & 180 & 68 & 40 & 63 \\
\hline
\end{tabular}

Source: Baun et al., 2003. 
Table 14: Content of organic substances in concrete fractions of C\&D waste

\begin{tabular}{|c|c|c|c|c|c|c|c|c|}
\hline \multicolumn{4}{|l|}{ Type of C\&D waste } & \multicolumn{4}{|c|}{ Pure concrete $0 / 32$} & \multirow{2}{*}{$\begin{array}{r}\begin{array}{r}\text { Pure con- } \\
\text { crete } 32 / 70 \\
\text { Plant } 4\end{array}\end{array}$} \\
\hline Plant & & Plant 1 & Plant 2 & Plant 3 & Plant 4 & Plant 5 & Plant 6 & \\
\hline Sample ID & & GA-1-B & GA-2-B & GA-3-B & GA-4-B & GA-5-B & GA-6-B & GA-4-B2 \\
\hline $\mathrm{C} 6-\mathrm{C} 10$ & $\mathrm{mg} / \mathrm{kg}$ & $<5$ & 6.4 & 5.5 & $<5$ & $<5$ & $<5.0$ & $<5.0$ \\
\hline $\mathrm{C} 10-\mathrm{C} 25$ & $\mathrm{mg} / \mathrm{kg}$ & 44 & 65 & 30 & 54 & 160 & 100 & 46 \\
\hline $\mathrm{C} 25-\mathrm{C} 35$ & $\mathrm{mg} / \mathrm{kg}$ & 100 & 120 & 54 & 73 & 98 & 120 & 110 \\
\hline Sum (C6 - C35) & $\mathrm{mg} / \mathrm{kg}$ & 150 & 190 & 90 & 130 & 260 & 220 & 160 \\
\hline Naphthalene & $\mathrm{mg} / \mathrm{kg}$ & 0.011 & 0.017 & $<0.005$ & $<0.005$ & 0.0065 & 0.0093 & $<0.005$ \\
\hline Acenaphthylene & $\mathrm{mg} / \mathrm{kg}$ & $<0.005$ & 0.0071 & $<0.005$ & $<0.005$ & 0.0065 & 0.011 & $<0.005$ \\
\hline Acenaphthene & $\mathrm{mg} / \mathrm{kg}$ & 0.006 & 0.0067 & $<0.005$ & $<0.005$ & $<0.005$ & 0.0092 & $<0.005$ \\
\hline Fluorene & $\mathrm{mg} / \mathrm{kg}$ & 0.0068 & 0.012 & $<0.005$ & $<0.005$ & $<0.005$ & 0.010 & $<0.005$ \\
\hline Phenanthrene & $\mathrm{mg} / \mathrm{kg}$ & 0.12 & 0.17 & 0.052 & 0.031 & 0.066 & 0.15 & 0.031 \\
\hline Anthracene & $\mathrm{mg} / \mathrm{kg}$ & 0.027 & 0.03 & 0.0095 & $<0.005$ & 0.013 & 0.034 & 0.007 \\
\hline Fluoranthene* & $\mathrm{mg} / \mathrm{kg}$ & 0.15 & 0.2 & 0.068 & 0.074 & 0.11 & 0.22 & 0.067 \\
\hline Pyrene & $\mathrm{mg} / \mathrm{kg}$ & 0.13 & 0.16 & 0.062 & 0.058 & 0.1 & 0.19 & 0.055 \\
\hline Benz(a)anthracene & $\mathrm{mg} / \mathrm{kg}$ & 0.076 & 0.083 & 0.03 & 0.025 & 0.045 & 0.084 & 0.034 \\
\hline Chrysen/Triphenylene & $\mathrm{mg} / \mathrm{kg}$ & 0.081 & 0.095 & 0.044 & 0.025 & 0.06 & 0.095 & 0.041 \\
\hline Benz $(b+j+k)$ fluoranthen* & $\mathrm{mg} / \mathrm{kg}$ & 0.1 & 0.13 & 0.054 & 0.038 & 0.098 & 0.13 & 0.059 \\
\hline Benzo(a)pyren* & $\mathrm{mg} / \mathrm{kg}$ & 0.058 & 0.071 & 0.025 & 0.019 & 0.053 & 0.083 & 0.025 \\
\hline Indeno(1,2,3-cd)pyren* & $\mathrm{mg} / \mathrm{kg}$ & 0.036 & 0.049 & 0.019 & 0.013 & 0.044 & 0.064 & 0.021 \\
\hline Dibenz(a,h)anthracen* & $\mathrm{mg} / \mathrm{kg}$ & 0.0083 & 0.01 & $<0.005$ & $<0.005$ & 0.0097 & 0.011 & $<0.005$ \\
\hline Benzo(g,h,i)perylen & $\mathrm{mg} / \mathrm{kg}$ & 0.03 & 0.042 & 0.018 & 0.011 & 0.04 & 0.063 & 0.019 \\
\hline Sum 16 PAH (16 EPA) & $\mathrm{mg} / \mathrm{kg}$ & 0.85 & 1.1 & 0.38 & 0.29 & 0.66 & 1.2 & 0.36 \\
\hline Sum 5 PAH (5 MST*) & $\mathrm{mg} / \mathrm{kg}$ & 0.35 & 0.46 & 0.17 & 0.15 & 0.31 & 0.51 & 0.18 \\
\hline PCB nr. 28 & $\mathrm{mg} / \mathrm{kg}$ & $<0.005$ & $<0.005$ & $<0.005$ & $<0.005$ & $<0.005$ & $<0.005$ & $<0.005$ \\
\hline PCB nr. 52 & $\mathrm{mg} / \mathrm{kg}$ & $<0.005$ & $<0.005$ & $<0.005$ & $<0.005$ & $<0.005$ & $<0.005$ & $<0.005$ \\
\hline PCB nr. 101 & $\mathrm{mg} / \mathrm{kg}$ & $<0.005$ & 0.017 & $<0.005$ & $<0.005$ & $<0.005$ & $<0.005$ & $<0.005$ \\
\hline PCB nr. 118 & $\mathrm{mg} / \mathrm{kg}$ & $<0.005$ & 0.0061 & $<0.005$ & $<0.005$ & $<0.005$ & $<0.005$ & $<0.005$ \\
\hline PCB nr. 138 & $\mathrm{mg} / \mathrm{kg}$ & $<0.005$ & 0.044 & $<0.005$ & $<0.005$ & $<0.005$ & $<0.005$ & $<0.005$ \\
\hline PCB nr. 153 & $\mathrm{mg} / \mathrm{kg}$ & $<0.005$ & 0.035 & $<0.005$ & $<0.005$ & $<0.005$ & $<0.005$ & $<0.005$ \\
\hline PCB nr. 180 & $\mathrm{mg} / \mathrm{kg}$ & $<0.005$ & 0.027 & $<0.005$ & $<0.005$ & $<0.005$ & $<0.005$ & $<0.005$ \\
\hline
\end{tabular}

Note: $\quad *$ indicates PAHs included in the sum of PAH 5.

Source: Baun et al., 2003. 
Table 15: Content of organic substances in concrete/tile, tile, concrete/asphalt and asphalt fractions of C\&D waste

\begin{tabular}{|c|c|c|c|c|c|c|c|c|c|}
\hline \multirow{2}{*}{$\begin{array}{l}\text { Type of C\&D waste } \\
\text { Plant }\end{array}$} & & \multicolumn{3}{|c|}{ Concrete/tile $0 / 32$} & \multirow{2}{*}{$\begin{array}{l}\text { Tile } \\
0 / 32 \\
\text { Plant } 5\end{array}$} & \multicolumn{2}{|c|}{$\begin{array}{c}\text { Concret/asphalt } \\
0 / 32\end{array}$} & \multicolumn{2}{|c|}{ Asphalt $0 / 32$} \\
\hline & & Plant 1 & Plant 2 & Plant 3 & & Plant 1 & Plant 6 & Plant 1 & Plant 6 \\
\hline Sample ID & & $\begin{array}{r}\text { GA-1- } \\
\text { BT }\end{array}$ & $\begin{array}{r}\text { GA-2- } \\
\text { BT }\end{array}$ & $\begin{array}{r}\text { GA-3- } \\
\text { BT }\end{array}$ & $\begin{array}{r}\text { GA-5- } \\
T\end{array}$ & $\begin{array}{r}\text { GA-1- } \\
\text { BA }\end{array}$ & $\begin{array}{r}\text { GA-6- } \\
\text { BA }\end{array}$ & $\begin{array}{r}\text { GA-1- } \\
\text { A }\end{array}$ & $\begin{array}{r}\text { GA-6- } \\
\text { A }\end{array}$ \\
\hline \multicolumn{10}{|l|}{ Fractions of hydrocarbons } \\
\hline $\mathrm{C} 6-\mathrm{C} 10$ & $\mathrm{mg} / \mathrm{kg}$ & $<5.0$ & $<5.0$ & $<5.0$ & $<5.0$ & $<5.0$ & $<5.0$ & $<5.0$ & 5.0 \\
\hline $\mathrm{C} 10-\mathrm{C} 25$ & $\mathrm{mg} / \mathrm{kg}$ & 94 & 96 & 38 & 29 & 340 & 450 & 600 & 980 \\
\hline $\mathrm{C} 25-\mathrm{C} 35$ & $\mathrm{mg} / \mathrm{kg}$ & 160 & 190 & 63 & 62 & 1,300 & 1,400 & 2,200 & 4,200 \\
\hline Sum (C6 - C35) & $\mathrm{mg} / \mathrm{kg}$ & 250 & 280 & 100 & 91 & 1,600 & 1,800 & 2,800 & 5,200 \\
\hline \multicolumn{10}{|l|}{ PAH compounds } \\
\hline Naphthalen & $\mathrm{mg} / \mathrm{kg}$ & 0.28 & 0.027 & 0.015 & 0.019 & 0.6 & 0.14 & 0.13 & 0.15 \\
\hline Acenaphthylen & $\mathrm{mg} / \mathrm{kg}$ & 0.15 & 0.087 & 0.021 & 0.0066 & 0.56 & 0.39 & 0.38 & 0.55 \\
\hline Acenaphthen & $\mathrm{mg} / \mathrm{kg}$ & 0.18 & 0.048 & 0.0078 & 0.045 & 0.42 & 0.21 & 0.21 & 0.21 \\
\hline Fluoren & $\mathrm{mg} / \mathrm{kg}$ & 0.27 & 0.12 & 0.028 & 0.032 & 0.93 & 0.27 & 0.39 & 0.23 \\
\hline Phenanthren & $\mathrm{mg} / \mathrm{kg}$ & 2.2 & 1.3 & 0.4 & 0.24 & 7.2 & 2.5 & 3 & 2.2 \\
\hline Anthracen & $\mathrm{mg} / \mathrm{kg}$ & 0.4 & 0.29 & 0.041 & 0.055 & 1.9 & 0.82 & 0.88 & 0.78 \\
\hline Fluoranthen* & $\mathrm{mg} / \mathrm{kg}$ & 2 & 1.4 & 0.47 & 0.42 & 7.3 & 2.8 & 5.1 & 4.4 \\
\hline Pyren & $\mathrm{mg} / \mathrm{kg}$ & 1.6 & 1.1 & 0.39 & 0.34 & 6.3 & 2.4 & 5.8 & 4.0 \\
\hline Benz(a)anthracen & $\mathrm{mg} / \mathrm{kg}$ & 0.78 & 0.53 & 0.17 & 0.24 & 2.9 & 0.95 & 2.4 & 1.3 \\
\hline Chrysen/Triphenylen & $\mathrm{mg} / \mathrm{kg}$ & 0.86 & 0.59 & 0.22 & 0.28 & 3.4 & 1.1 & 3 & 1.5 \\
\hline Benz $(b+j+k)$ fluoranthen* & $\mathrm{mg} / \mathrm{kg}$ & 1.1 & 0.81 & 0.33 & 0.41 & 5.4 & 1.8 & 5.2 & 3.4 \\
\hline Benzo(a)pyren* & $\mathrm{mg} / \mathrm{kg}$ & 0.62 & 0.45 & 0.17 & 0.21 & 3.3 & 1.1 & 3.1 & 1.9 \\
\hline Indeno(1,2,3-cd)pyren* & $\mathrm{mg} / \mathrm{kg}$ & 0.43 & 0.33 & 0.12 & 0.13 & 2.6 & 0.63 & 2.5 & 1.3 \\
\hline Dibenz(a,h)anthracen* & $\mathrm{mg} / \mathrm{kg}$ & 0.092 & 0.071 & 0.025 & 0.037 & 0.47 & 0.13 & 0.46 & 0.30 \\
\hline Benzo(g,h,i)perylen & $\mathrm{mg} / \mathrm{kg}$ & 0.34 & 0.24 & 0.094 & 0.099 & 2.1 & 0.59 & 2 & 1.3 \\
\hline Sum 16 PAH (16 EPA) & $\mathrm{mg} / \mathrm{kg}$ & 9.1 & 7.4 & 2.5 & 2.6 & 45 & 16 & 34 & 24 \\
\hline Sum 7 PAH (7 MST*) & $\mathrm{mg} / \mathrm{kg}$ & 4.2 & 3.1 & 1.1 & 1.2 & 19 & 6.5 & 16 & 11 \\
\hline \multicolumn{10}{|l|}{ Polychlorinated biphenyls } \\
\hline PCB nr. 28 & $\mathrm{mg} / \mathrm{kg}$ & $<0.005$ & $<0.005$ & $<0.005$ & $<0.005$ & $<0.005$ & $<0.005$ & $<0.005$ & 0.005 \\
\hline PCB nr. 52 & $\mathrm{mg} / \mathrm{kg}$ & $<0.005$ & $<0.005$ & $<0.005$ & $<0.005$ & $<0.005$ & $<0.005$ & $<0.005$ & 0.005 \\
\hline PCB nr. 101 & $\mathrm{mg} / \mathrm{kg}$ & $<0.005$ & $<0.005$ & $<0.005$ & $<0.005$ & 0.0076 & $<0.005$ & $<0.005$ & 0.005 \\
\hline РCB nr. 118 & $\mathrm{mg} / \mathrm{kg}$ & $<0.005$ & $<0.005$ & $<0.005$ & $<0.005$ & $<0.005$ & $<0.005$ & $<0.005$ & 0.005 \\
\hline PCB nr. 138 & $\mathrm{mg} / \mathrm{kg}$ & $<0.005$ & $<0.005$ & $<0.005$ & $<0.005$ & 0.017 & $<0.005$ & $<0.005$ & 0.005 \\
\hline PCB nr. 153 & $\mathrm{mg} / \mathrm{kg}$ & $<0.005$ & $<0.005$ & $<0.005$ & $<0.005$ & 0.013 & $<0.005$ & $<0.005$ & 0.005 \\
\hline PCB nr. 180 & $\mathrm{mg} / \mathrm{kg}$ & $<0.005$ & $<0.005$ & $<0.005$ & $<0.005$ & 0.0085 & $<0.005$ & $<0.005$ & 0.005 \\
\hline
\end{tabular}

Note: $\quad *$ indicates PAHs included in the sum of PAH 5.

Source: Baun et al., 2003.

Results of the leaching tests are shown in Table 16 (inorganic substances) and Table 17 (organic substances). Table 16 also shows the leaching limit values from Statutory Order no. 1662/2010 and results that exceed the limit values for Category 1 and 2 are shown in bold. It can be seen that $\mathrm{Cr}$ leaching appear to be a potential problem for all fractions, and $\mathrm{Cu}$ and $\mathrm{Ni}$ may cause problems for some fractions if judged by Statutory Order $1662 / 2011$.

The observed leaching of organic substances from the C\&D waste fractions studied is generally quite low. 
Table 16: Results of one-stage batch leaching (EN 12457-2, part 1) at L/S = $2 \mathrm{l} / \mathrm{kg}$ for inorganic substances. Leaching limit values from Statutory Order 1662/2010 are also shown and results exceeding Category 1 and 2 limits are shown in italics

\begin{tabular}{|c|c|c|c|c|c|c|c|c|c|c|}
\hline \multicolumn{2}{|c|}{ Type of C\&D waste } & \multicolumn{3}{|c|}{ Concrete $0 / 32$} & \multirow{2}{*}{$\begin{array}{r}\text { Tile 0/32 } \\
\text { Plant } 5\end{array}$} & \multicolumn{2}{|c|}{ Concrete/tile $0 / 32$} & \multirow{2}{*}{$\begin{array}{l}\begin{array}{l}\text { Concr./asph. } \\
0 / 32 \\
\text { Anlæg } 1\end{array}\end{array}$} & \multicolumn{2}{|c|}{$\begin{array}{l}\text { Limit values Stat. } \\
\text { Ord. } 1662\end{array}$} \\
\hline Plant & & Plant 2 & Plant 3 & Plant 4 & & Plant 2 & Plant 3 & & Kat. 1 og 2 & Kat. 3 \\
\hline Sample-ID & & GA-2-B & GA-3-B & BA-4-B & GA-5-T & BA-2-BT & GA-3-BT & GA-1-BA & & \\
\hline $\mathrm{pH}$ & & 12.2 & 12.4 & 12.3 & 11.3 & 11.6 & 11.8 & 11.8 & - & - \\
\hline Conduct. & $\mathrm{mS} / \mathrm{m}$ & 360 & 780 & 480 & 160 & 180 & 240 & 210 & - & - \\
\hline Chloride & $\mathrm{mg} / \mathrm{kg}$ & 69 & 24 & 54 & 120 & 190 & 120 & 180 & 300 & 6,000 \\
\hline Sulphate & $\mathrm{mg} / \mathrm{kg}$ & 39 & 18 & 9.6 & 1,000 & 480 & 200 & 35 & 500 & 8,000 \\
\hline $\mathrm{Ca}$ & $\mathrm{mg} / \mathrm{kg}$ & 570 & 2,000 & 740 & 460 & 420 & 380 & 320 & - & - \\
\hline $\mathrm{Na}$ & $\mathrm{mg} / \mathrm{kg}$ & 85 & 44 & 78 & 86 & 96 & 100 & 99 & 200 & 3,000 \\
\hline As & $\mu \mathrm{g} / \mathrm{kg}$ & $<1.6$ & $<1.6$ & $<1.6$ & 2.8 & 5.0 & 4.2 & 1.6 & 16 & 100 \\
\hline $\mathrm{Cd}$ & $\mu \mathrm{g} / \mathrm{kg}$ & $<0.4$ & $<0.4$ & $<0.4$ & $<0.4$ & $<0.4$ & $<0.4$ & $<0.4$ & 4 & 80 \\
\hline $\mathrm{Cr}$ & $\mu \mathrm{g} / \mathrm{kg}$ & 91 & 32 & 88 & 180 & 120 & 110 & 39 & 20 & 1,000 \\
\hline $\mathrm{Cu}$ & $\mu \mathrm{g} / \mathrm{kg}$ & 51 & 18 & 26 & 50 & 130 & 140 & 150 & 90 & 4,000 \\
\hline $\mathrm{Ni}$ & $\mu \mathrm{g} / \mathrm{kg}$ & 17 & 13 & 11 & 15 & 24 & 58 & 24 & 20 & 140 \\
\hline $\mathrm{Pb}$ & $\mu \mathrm{g} / \mathrm{kg}$ & $<2.0$ & $<2.0$ & $<2.0$ & $<2.0$ & $<2.0$ & $<2.0$ & 2.0 & 20 & 200 \\
\hline $\mathrm{Zn}$ & $\mu \mathrm{g} / \mathrm{kg}$ & $<20$ & $<20$ & $<20$ & $<20$ & $<20$ & $<20$ & $<20$ & 200 & 3,000 \\
\hline $\mathrm{Ba}$ & $\mu \mathrm{g} / \mathrm{kg}$ & 160 & 1,200 & 520 & 44 & 46 & 100 & 120 & 600 & 8,000 \\
\hline $\mathrm{Mn}$ & $\mu \mathrm{g} / \mathrm{kg}$ & $<30$ & $<30$ & $<30$ & $<30$ & $<30$ & $<30$ & $<30$ & 300 & 2,000 \\
\hline $\mathrm{Hg}$ & $\mu \mathrm{g} / \mathrm{kg}$ & 0.042 & 0.031 & 0.045 & 0.019 & 0.054 & 0.037 & 0.024 & 0.2 & 2 \\
\hline
\end{tabular}

Source: Baun et al. 2003. 
Table 17: Results of equilibrium column leaching tests for organic substances

\begin{tabular}{|c|c|c|c|c|c|c|c|c|}
\hline \multirow{2}{*}{$\begin{array}{l}\text { Type of C\&D waste } \\
\text { Plant }\end{array}$} & & \multirow{2}{*}{$\begin{array}{l}\text { Concrete } \\
\text { Anlæg } 2\end{array}$} & \multirow{2}{*}{$\begin{array}{c}\text { Tile } \\
\text { Anlæg } 5\end{array}$} & \multirow{2}{*}{$\begin{array}{l}\begin{array}{c}\text { Concrete/ } \\
\text { tile }\end{array} \\
\text { Anlæg } 2\end{array}$} & \multicolumn{2}{|c|}{ Concrete/asphalt } & \multicolumn{2}{|c|}{ Asphalt } \\
\hline & & & & & Anlæg 1 & Anlæg 6 & Anlæg 1 & Anlæg 6 \\
\hline Sample-ID & & GA-2-B & GA-5-T & GA-2-BT & GA-1-BA & GA-6-BA & GA-2-A & GA-6-A \\
\hline $\mathrm{pH}$ & & 12.2 & 11.7 & 11.8 & 11.7 & 11.7 & 8.6 & 10.6 \\
\hline Conductivity & $\mathrm{mS} / \mathrm{m}$ & 330 & 170 & 190 & 230 & 160 & 80 & 65 \\
\hline \multicolumn{9}{|l|}{ Fractions of hydrocarbons } \\
\hline C6-C10 & $\mathrm{mg} / \mathrm{kg}$ & $<0.02$ & $<0.02$ & 0.028 & $<0.02$ & $<0.02$ & $<0.02$ & $<0.02$ \\
\hline $\mathrm{C} 10-\mathrm{C} 25$ & $\mathrm{mg} / \mathrm{kg}$ & 0.054 & 0.060 & 0.20 & 0.15 & 0.11 & 0.062 & 0.053 \\
\hline C25-C35 & $\mathrm{mg} / \mathrm{kg}$ & 0.14 & $<0.08$ & 0.32 & 0.15 & 0.14 & 0.70 & $<0.08$ \\
\hline Sum (Benzen-C35) & $\mathrm{mg} / \mathrm{kg}$ & 0.19 & 0.060 & 0.56 & 0.31 & 0.24 & 0.76 & 0.053 \\
\hline \multicolumn{9}{|l|}{ PAH compounds } \\
\hline Naphthalen & $\mu \mathrm{g} / \mathrm{kg}$ & 1.5 & 0.19 & 3.2 & 8 & 3 & $<0.02$ & 2.6 \\
\hline Acenaphthylen & $\mu \mathrm{g} / \mathrm{kg}$ & 0.22 & 0.06 & 2.4 & 1.4 & 0.88 & 0.94 & 0.32 \\
\hline Acenaphthen & $\mu \mathrm{g} / \mathrm{kg}$ & 0.76 & 0.2 & 2.2 & 1.6 & 0.88 & $<0.02$ & 0.53 \\
\hline Fluoren & $\mu \mathrm{g} / \mathrm{kg}$ & 0.56 & 0.096 & 3.4 & 1.5 & 0.68 & 0.022 & 0.34 \\
\hline Phenanthren & $\mu \mathrm{g} / \mathrm{kg}$ & 5.2 & 0.84 & 11 & 3.9 & 2.4 & 0.094 & 1.4 \\
\hline Anthracen & $\mu \mathrm{g} / \mathrm{kg}$ & 0.76 & 0.18 & 2.6 & 0.97 & 0.66 & 0.38 & 0.46 \\
\hline Fluoranthen & $\mu \mathrm{g} / \mathrm{kg}$ & 1.6 & 0.82 & 2.2 & 0.85 & 0.74 & 1.1 & 0.69 \\
\hline Pyren & $\mu \mathrm{g} / \mathrm{kg}$ & 0.88 & 0.6 & 1.2 & 0.54 & 0.52 & 3.2 & 0.5 \\
\hline Benz (a) anthracen & $\mu \mathrm{g} / \mathrm{kg}$ & 0.096 & 0.086 & 0.13 & 0.087 & 0.08 & 0.7 & 0.089 \\
\hline Chrysen/Triphenylen & $\mu \mathrm{g} / \mathrm{kg}$ & 0.12 & 0.1 & 0.11 & 0.083 & 0.084 & 1.3 & 0.1 \\
\hline Benz $(b+j+k)$ fluoranthen & $\mu \mathrm{g} / \mathrm{kg}$ & 0.066 & 0.054 & 0.044 & 0.12 & 0.09 & 4.6 & 0.13 \\
\hline Benzo (a) pyren & $\mu \mathrm{g} / \mathrm{kg}$ & 0.022 & $<0.02$ & $<0.02$ & 0.056 & 0.038 & 3.2 & 0.057 \\
\hline Indeno $(1,2,3-c d)$ pyren & $\mu \mathrm{g} / \mathrm{kg}$ & 0.022 & $<0.02$ & $<0.02$ & 0.056 & 0.044 & 2.6 & 0.051 \\
\hline Dibenz $(a, h)$ anthracen & $\mu \mathrm{g} / \mathrm{kg}$ & $<0.02$ & $<0.02$ & $<0.02$ & $<0.02$ & $<0.02$ & 0.52 & $<0.02$ \\
\hline Benzo $(g, h, i)$ perylen & $\mu \mathrm{g} / \mathrm{kg}$ & $<0.02$ & $<0.02$ & $<0.02$ & 0.06 & 0.042 & 2.4 & 0.057 \\
\hline Sum 16 PAH (US-EPA) & $\mu \mathrm{g} / \mathrm{kg}$ & 12 & 3.2 & 28 & 19 & 10 & 22 & 7.3 \\
\hline Sum 5 PAH (MST) & $\mu \mathrm{g} / \mathrm{kg}$ & 1.7 & 0.87 & 2.2 & 1.1 & 0.91 & 12 & 0.93 \\
\hline \multicolumn{9}{|l|}{ Polychlorinated biphenyls } \\
\hline PCB nr. 28 & $\mu \mathrm{g} / \mathrm{kg}$ & $<0.02$ & $<0.02$ & $<0.02$ & $<0.02$ & $<0.02$ & $<0.02$ & $<0.02$ \\
\hline PCB nr. 52 & $\mu \mathrm{g} / \mathrm{kg}$ & $<0.02$ & $<0.02$ & $<0.02$ & $<0.02$ & $<0.02$ & $<0.02$ & $<0.02$ \\
\hline PCB nr. 101 & $\mu \mathrm{g} / \mathrm{kg}$ & $<0.02$ & $<0.02$ & $<0.02$ & $<0.02$ & $<0.02$ & $<0.02$ & $<0.02$ \\
\hline PCB nr. 118 & $\mu \mathrm{g} / \mathrm{kg}$ & $<0.02$ & $<0.02$ & $<0.02$ & $<0.02$ & $<0.02$ & $<0.02$ & $<0.02$ \\
\hline PCB nr. 138 & $\mu \mathrm{g} / \mathrm{kg}$ & $<0.02$ & $<0.02$ & $<0.02$ & $<0.02$ & $<0.02$ & $<0.02$ & $<0.02$ \\
\hline PCB nr. 153 & $\mu \mathrm{g} / \mathrm{kg}$ & $<0.02$ & $<0.02$ & $<0.02$ & $<0.02$ & $<0.02$ & $<0.02$ & $<0.02$ \\
\hline PCB nr. 180 & $\mu \mathrm{g} / \mathrm{kg}$ & $<0.02$ & $<0.02$ & $<0.02$ & $<0.02$ & $<0.02$ & $<0.02$ & $<0.02$ \\
\hline
\end{tabular}

Source: Baun et al., 2003.

A study has been performed (MST, 2006) in which a list of 12 particularly problematic substances in C\&D waste has been identified. They are: $\mathrm{Cd}$, $\mathrm{Cr}, \mathrm{Cu}, \mathrm{Hg}, \mathrm{Ni}, \mathrm{Pb}, \mathrm{Zn}, \mathrm{PCBs}$, chloroparafins, chlorofluorocarbons (CFCs), hydrochlorofluorocarbons (HCFCs) and hydrofluorocarbons (HCFs), and sulphur-hexafluoride (SF6). The report also discusses the potential sources of these contaminants as well as possible initiatives that could reduce the contamination of $C \& D$ waste with these substances. The main sources of these substances were indicated as shown below: 
$\mathrm{Cd}$

$\mathrm{Cr}$

$\mathrm{Cu}$

$\mathrm{Hg}$

$\mathrm{Ni}$

$\mathrm{Pb}$

$\mathrm{Zn}$

PCBs

Chloroparafins

CFCs

HCFCs and HCFs

SF6
Plastic (cables, pipes, roofing plates), embedded in zinc products, cement.

Stainless steel, others (e.g. painted surfaces).

Cables and wires, various installations, roofs, pipes, screws, locks, fittings, pigment.

Fluorescent tubes, electrical switches, relays, cement.

Stainless steel, surface treatment.

Covers, roofs end electrical cables.

Gutters, pipes, galvanized products, plastic (particularly gutters and pipes).

Small condensators, sealed glazing (glue), sealants (plasticisers), paints (pigments).

Plastic (general), sealants (plasticisers), others (e.g. glue).

Isolation materials - PUR foam, other isolation materials.

Isolation materials - PUR foam, sealing foam.

Soundproof windows.

\section{Functional criteria for recycling of C\&D waste as aggregates}

In order to be recycled for a specific purpose an aggregate must fulfil both application-specific functional and environmental criteria. Although functional criteria will not be addressed in this report, some Danish quality criteria for recycling of crushed concrete aggregates as unbound road base materials are presented below.

The Danish Road Institute has produced guideline for the use of crushed concrete aggregates as unbound road base materials (DRI, 2002). This guideline sets quality criteria for the crushed concrete in terms of elasticity, particle size distribution, strength/resistance to abrasion and purity (i.e. content of other materials than concrete). Based on purity, the crushed concrete is split into three different quality groups, see Table 18. It should be noted that these purity criteria are purely functional, and they are not approved by the Danish EPA in relation to environmental protection. 
Table 18: Purity requirements for classes of crushed concrete according to DRI (2002)

\begin{tabular}{|c|c|c|c|c|c|}
\hline \multirow[t]{2}{*}{ Fraction } & \multicolumn{2}{|r|}{ Group } & \multicolumn{3}{|c|}{ Content } \\
\hline & Name & Constituents & $\begin{array}{l}\text { Quality A } \\
\text { Weight \% }\end{array}$ & $\begin{array}{l}\text { Quality B } \\
\text { Weight \% }\end{array}$ & $\begin{array}{l}\text { Quality C } \\
\text { Weight \% }\end{array}$ \\
\hline \multirow[t]{6}{*}{$>4 \mathrm{~mm}$} & "Concrete" & Concrete and natural materials & $\geq 98$ & $\geq 95$ & $\geq 80$ \\
\hline & “Tiles" & $\begin{array}{l}\text { Tiles, lightweight concrete, expanded clay } \\
\text { and mortar }\end{array}$ & $\leq 2.0$ & $\leq 5.0$ & $\leq 20$ \\
\hline & "Asphalt" & Crushed asphalt & $\leq 2.0$ & $\leq 2.0$ & $\leq 2.0$ \\
\hline & $\begin{array}{l}\text { "Other, non- } \\
\text { harmful" }\end{array}$ & $\begin{array}{l}\text { Glass, porcelain, hard plast, iron and } \\
\text { similar hard materials }\end{array}$ & $\leq 2.0$ & $\leq 5.0$ & $\leq 20$ \\
\hline & $\begin{array}{l}\text { "Other, } \\
\text { harmful" }\end{array}$ & $\begin{array}{l}\text { Wood, paper, light isolation materials* } \\
\text { (styropor, polyurethane, etc.), soft plastic, } \\
\text { slags, etc.. }\end{array}$ & $\leq 0.5$ & $\leq 1.0$ & $\leq 2.0$ \\
\hline & & *Light isolation material alone & $\leq 0.02$ & $\leq 0.02$ & $\leq 0.02$ \\
\hline
\end{tabular}

Other relevant functional quality criteria for C\&D waste to be recycled as aggregates may be found in the product standards specifying the requirements for CE marking of construction products, which apply to both virgin and recycled materials. Some examples of these are:

- EN 13242: Aggregates for unbound and hydraulically bound materials for use in civil engineering work and road construction.

- EN 13043: Aggregates for bituminous mixtures and surface treatments for roads, airfields and other traficked areas.

- EN 13285: Unbound mixtures - Specification.

These product standards currently address a number of product quality requirements on properties such as e.g. geometry, size and grading, shape of particles, fines content and quality, resistance to fragmentation, particle density, water absorption, total sulphur, acid soluble sulphur, durability, resistance to freezing and thawing. Over the next years the standards will be supplemented with requirements on release of "dangerous" substances to indoor air, soil, groundwater and surface water in accordance with the Construction Products Directive (89/106/EEC). 



\section{Appendix 2: Management of C\&D waste in the Faroe Islands}

\section{Management of C\&D waste in the Faroe Islands}

The main objective of the environmental protection act of the Faroe Islands with respect to waste is to prevent pollution and promote recycling. The environmental permits for the receiving stations for waste in the Faroe Islands emphasise that iron, metal, tyres, trawls and nets, electronics, glass, paper and waste oil must be recycled, and that hazardous waste must be managed separately. At present, no concrete steps have been taken towards an EoW policy (í Horni, 2010). The Faroe Islands are not a member of the EU and are hence not bound by the EU Waste Framework Directive.

Efforts are made to get better waste statistics for the Farao Islands, primarily aiming at information on the various fractions of the total amount of waste and not at the origin of the waste. At present, there are no data on the amount of waste originating from construction and demolition activities. One of the reasons for this is that the waste transfer stations receive waste from both private households and smaller entreprises, which complicates a possible data collection.

Only parts of the waste, including C\&D waste, are being recycled or treated, namely metal, electronics and hazardous waste. In addition, clean soil is recycled. The collected metal, electronic and hazardous waste is sent abroad for further treatment. In 2009, the following approximate amounts were shipped out for treatment:

- Metal waste: 5,000 tonnes.

- Electronic waste: 350 tonnes.

- Hazardous waste: 200 tonnes. 
The above amounts are total amounts, not only C\&D waste. A substantial amount of the C\&D waste produced in the Faroe Islands is landfilled: Concrete, waste asphalt, gravel, flagstones, gypsym boards, isolation materials, PVC, asbestos, fibre cement roofing sheets, impregnated wood and contaminated soil.

Unimpregnated wood and plastics are taken to an incinerator where the surplus heat is used for heating of houses. Source: í Horni (2010). 


\title{
Appendix 3: Management of C\&D waste in Finland
}

\author{
Utilisation of C\&D waste as aggregates in Finland
}

\section{C\&D waste: Description, generation and amounts}

C\&D waste can be divided into three types of waste, originating from: new construction, renovation and demolition. Waste from renovation sites resembles demolition waste, but contains more interior material. Construction waste contains soil material (arising in foundation works, roads) over-ordering, off-cuts and damaged material and, in some cases, is "cleaner" than demolition waste. Packaging waste makes also up a significant part of this waste stream. Demolition waste, on the other hand, is made up of several sub-waste streams and its composition is influenced by the selective demolition technique used.

C\&D waste covers following main waste types:

- Soil and rock.

- Concrete, tiles/bricks, mortar, wood, metals, plastics/plaster-board and so-called packages waste, but also soil (gravel, sand).

- Composite/complex marketable materials (e.g. windows, doors).

The most important fraction of C\&D waste is inert (bricks, stones, concrete, tiles) usually comprising at least $70 \%$ of all "core" C\&D waste. Only the mineral part of the C\&D waste can be used as a potential aggregate. This document only focuses only on concrete waste even if also soil material is often used as a filling material or aggregate in earth constructions.

The total waste amount produced in the construction sector in Finland was about $25.5 \mathrm{Mt}$ in 2007 contra 23.1 Mt in 2006. Most of it is mineral waste including soil-like materials (see Figure 4). Information of C\&D wastes have also been gathered in the JRC report (2009). Based on the Commission report (IPTS, 2009), 33\% of the C\&D waste produced in Finland in 2006 consisted of concrete and masonry (tiles), 41\% was timber, $14 \%$ metal and $12 \%$ consisted of miscellaneous materials, including glass, 
plastics and other wastes. This differs somewhat from Figure 4, probably due to the definitions of the waste stream.

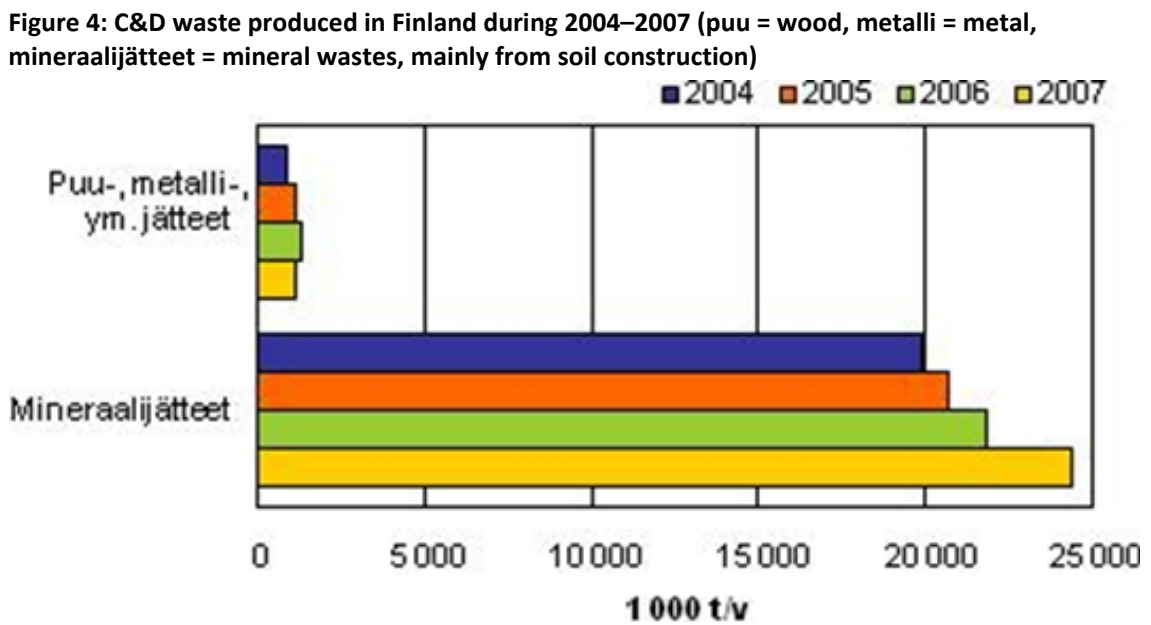

\section{Mineral C\&D waste for aggregate production}

The focus here is on the following waste streams (the EWC code in brackets):

- Concrete (17 0101$)$.

- Bricks $(170102)$.

- Tiles and ceramics (17 0103 ).

- Mixture of concrete, bricks, tiles and ceramics not containing dangerous substances (17 01 07).

\section{Origin and quality}

There are two main types of concrete wastes:

- $\quad$ Concrete waste from manufacturing process, e.g. hollow core slab waste, overflow materials.

- Mineral demolition waste, mainly concrete and bricks, from selective demolition of constructions (e.g. bridge) and buildings.

The first waste stream is continuously generated in the manufacturing process and is typically almost pure concrete containing minor residues of mineral and plant oil used in the moulding. The waste amount produced yearly is around 700,000 tonnes (Makela \& Hoynala, 2000; Sarinen, 
2010). This waste is typically alkaline (pH over 11) and the content of heavy metals is generally low. The release of sulphate is usually low. Mainly the alkalinity of the waste needs to be taken into account in evaluation of the suitable use of this waste.

The amount of the latter waste stream (the concrete-based demolition waste) produced in Finland is several hundred thousand tonnes per year (estimated in 2000 as $0.5-1 \mathrm{Mt} / \mathrm{a}$ ). This waste stream is generated "on-site" at a restricted time. The upgrading of the waste can be done either on-site or off-site. In the latter case waste streams from several demolitions sites are brought to one place for processing. The quality is dependent on type of the construction (e.g. materials), the use of the construction and especially on the accuracy of the selective demolition system used. An essential prerequisite for the use is selective demolition, which ensures that the material does not contain excessive amounts of harmful substances or other impurities that may reduce its environmental and technical suitability or totally hinder its use. Mineral demolition wastes should not be recovered from constructions contaminated by industrial activity or spills.

Typically wastes from the construction buildings contain beside concrete fractions, also bricks, gypsum, mortar and wood depending on the type of demolition process, the selectivity of the demolition technique and also on the whole process chain (e.g. storage). The technical and also the environmental quality of the waste is hampered if the non-concrete fraction is significant (e.g. over 10-30\% depending on end-use). Examples of potentially harmful materials are preserved wood, electronic equipment, plastics, adhesives, sealing materials, asbestos, fluorescent lamps, gypsum materials, and tarry material. A list of harmful compounds, which may be present in materials or equipment used in the construction industry, is presented in Table 19. The list does not include asbestos, because due to Finnish regulations asbestos always needs to be removed from the buildings before demolition.

Potentially harmful materials should be identified and removed before demolition. The content of harmful materials in building wastes has been estimated in a Swedish report (Sigfrid, L. Miljöstörande material i rivningsavfall. Reforsk FoU 81, Sweden (1993)) to be about 1\% of total mass. The age and the use of the building to be demolished significantly influence the amount of harmful materials. Cadmium for example was used in PVC-plastics as stabiliser and colour pigment during the 1960s and 1970s. The amount of cadmium in plasticised PVC was 0.03-0.06 weight- $\%$ and in hard PVC $0.012-0.36$ weight-\%. Another example is the use of sealing compounds for wall elements containing polysulphides. 
The PCB-contents in these compounds were at least $20 \%$. Moreover, plasterboard should be separated from concrete owing to its sulphate content, blue or green coloured concrete because of its copper content, and moisture barriers because of creosote, etc.

The leached amounts of harmful compounds from the demolition wastes are generally low. Predominantly, only sulphate and chromium are leached. The leaching of sulphate and metals is typically higher from building demolition waste than from e.g. hollow-core slab waste.

Formerly most of the material was landfilled. It was, however, found that due to its self-hardening properties, crushed demolition waste containing unreacted cementitious compounds is technically well suited to road construction. It has a 2-3 times better bearing capacity than gravel or crushed rock, which allows for a reduction in the road base thickness. A reduction in material use also means that the life cycle environmental impacts of road construction are reduced compared to traditional materials.

Table 19: Harmful compounds in mineral demolition wastes

\begin{tabular}{ll} 
Harmful compound & Application \\
\hline $\begin{array}{l}\text { Organicly bound cadmium } \\
\text { Metallic cadmium }\end{array}$ & Stabilisers in plastics \\
Metallic mercury & Surface finishing agents \\
Metallic lead & Indicators and switches in electrical installations \\
Organic lead & Sealing in sewer drains \\
PCB-compounds & Additive in plastics \\
CFC-compounds & Sealing compounds, condensers and anti-slip floor covering \\
Oil and PAH & Freezing agents and polymeric insulating materials \\
Chromium (molybdenum) & Oil spills, e.g. from machines, in felt roof, tarry compounds \\
Copper & Concrete, mortar \\
Phenolic compounds & Wires, copper water pipes \\
\hline
\end{tabular}

\section{Processing of concrete waste (production of aggregate)}

The main steps in the production are the separation and recovery of concrete of construction, intermediate storage of blocks, transport of waste to crushing unit (in case of off-site crushing, crushing), storage of crushed material and delivery to the users (see Figure 5). Quality controls performed in each steps is crucial for ensuring that the product is suitable for use in earth construction. Especially at off-site crushing the purity of the waste has to be checked visually both at the reception of the waste and during the crushing. For example the content of brick and wood in the crushed material is restricted for ensuring a technical quality of the end-product. Metals (iron) are usually separated in conjunction with the crushing. 
Figure 5: Steps in production of reclaimed crushed concrete for use in earth construction

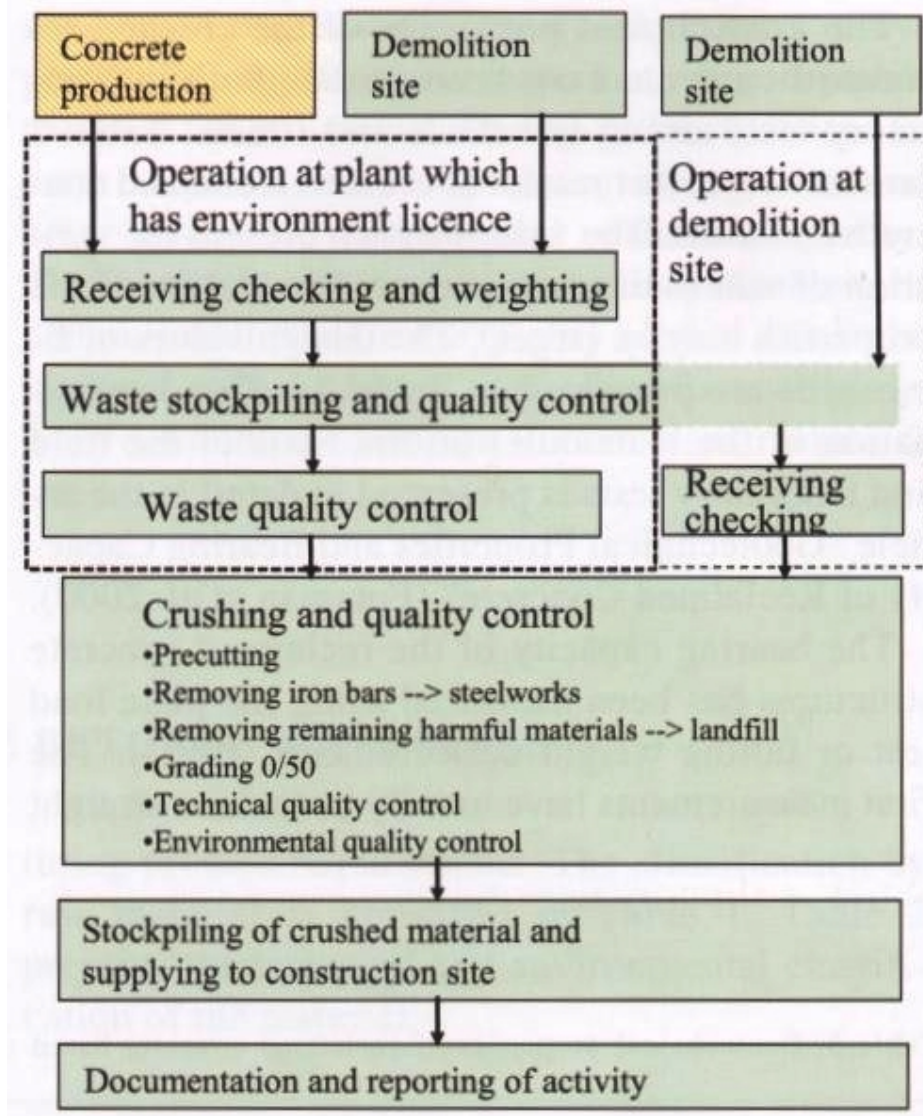

\section{Quality control and the Finnish Standard SFS 5884}

Quality control is crucial in the production of a high quality end-product to be used as an aggregate. Especially the responsibilities of all involved actors starting from development of the demolition plan ending at the use of material as construction material in the chosen application need to be defined and should be included in a quality assurance system for the whole production. The company responsible for the crushing has to check that the input waste material delivered for crushing fulfil the requirements and has to prepare a product information sheet including design manual and work instruction. The end-user is responsible for that the product is used according to the instructions. 
SFS standard 5884 which defines the procedure and requirements for production control of secondary materials was published in 2001. The standard specifies the basic requirements for a production control system, technical and environmental classification of crushed concrete products, technical and environmental properties to be monitored as well as sampling and monitoring methods. Requirements for the management of deviations and reporting are also presented. The standard is material specific. The waste is further also classified into four classes by raw material and technical properties.

The scope and the base of the SFS STANDARD 5884 are following:

- Waste from selective demolition (origin of material known).

- Professional operation.

- Material classification according to technical and environmental properties.

Examples of quality parameters (SFS 5884):

- Purity of received waste, which should be checked visually both when material is received and at different stages of manufacturing process.

- Grain-size distribution and frost susceptibility.

- Compressive strength.

- Purity of produced material (amount of organic impurities and the amount of brick).

- Environmental acceptability based on leaching of the compounds that are most likely to exceed applicability criteria for the application in question.

More specific information on the development of the standard is presented in the Wascon paper (Mroueh, 2003). 


\section{Finnish policy/strategy and legislation concerning use in earth construction}

\section{General}

One of the key areas of the "Finnish National Waste Plan to the year 2016" is the sustainable management of waste from construction and demolition by especially by promoting waste separation and reuse/recycling (and also by ban of disposal organic waste at landfill).

In July 2008, Finland commented as follows on the JRC EoW report related to without testing needs for $C \& D$ wastes from selective demolition of structures:

\footnotetext{
"A discussion on quality control check of C\& D is needed. In Finland quality of reclaimed concrete is always checked by using a leaching test. Most critical parameter is sulphate due to presence of gypsum, bricks, mortar. According to our experience a product control works in two ways: partly it is a check on the waste to be used (standardised production control helps to ensure the acceptance of the material as a quality product), partly it promotes a proper depollution or selective demolition process because the final product is randomly checked."
}

\section{The Finnish decree (Government Decree 591/2006) on reuse of some waste materials in earth construction}

The Finnish decree (Government Decree 591/2006, rev. 403/2009) on reuse of some waste materials in earth construction was approved in 2006, revised in 2009. The purpose was to promote through simplification of the environmental permit system the use of selected wastes in earth construction fulfilling the requirements defined in the Finnish Decree.

The decree is material specific and covers the following waste materials:

- Concrete chippings (EWC codes 1013 14, 170101 and 19 12 12).

- Fly ashes (EWC codes 1001 02,10 01 03, 100117 and 1001 24)) and bottom ashes (EWC codes 1001 01, 1001 15) from combustion of coal, peat and wood-based material.

Scope and content of the Decree is shown in Table 20 and the technical specifications and environmental requirements are listed in Table 21.

The Decree is based on the protection of soil and groundwater. Limit values are given both on total content and on the release of metals and salts both for basic characterization and compliance testing (focusing only on key elements). The limit values for recycling of concrete-based C\&D waste for earth construction purposes are shown in Table 21. 
The table addresses concrete chippings (codes of waste 13101314,17 0101 and 1912 12). Concrete chippings refer to waste made of dismantled concrete structures or concrete waste from new buildings and the concrete industry by crushing the material into grains with a maximum diameter of $150 \mathrm{~mm}$ (content of bricks max. 30\%).

The determination of harmful substances included in the waste and leaching from it shall be conducted, in the first instance, by using standardised and, secondarily, other methods found adequate in terms of sensitivity of detection, accuracy and repeatability.

Table 20: Scope and content of Finnish Decree on reuse of some waste in earth construction

\begin{tabular}{|c|c|}
\hline Aspect & Specification \\
\hline National regulation & $\begin{array}{l}\text { Government Decree 591/2006 which covers the use of selected environmentally } \\
\text { compliant waste materials in construction projects } \\
\text { Current regulation covers reclaimed crushed concrete, ash from coal, peat, } \\
\text { wood combustion }\end{array}$ \\
\hline $\begin{array}{l}\text { Definition of waste } \\
\text { of concern }\end{array}$ & $\begin{array}{l}\text { Non-hazardous, mainly mineral waste (typically less than } 3 \% \text { TOC) } \\
\text { General material specifications based on total content (mainly to be used for material } \\
\text { identification) }\end{array}$ \\
\hline $\begin{array}{l}\text { Type of use } \\
\text { (restrictions) }\end{array}$ & $\begin{array}{l}\text { Institutional or commercial use in the following constructions: } \\
\text { - Public roads, streets, bicycle lanes, pavements and areas directly connected to these } \\
\text { necessary for road maintenance or traffic, excluding noise barriers } \\
\text { - Parking areas } \\
\text { - Sports grounds as well as routes in recreational and sports areas } \\
\text { - Railway yards as well as storage fields and roads in industrial areas, waste processing } \\
\text { areas and air traffic areas. Roads, streets, pavements and areas directly related to those } \\
\text { - The Decree shall only apply to earthworks with the approved plan (street plan, road } \\
\text { plan, action plan for a public area), excluding forest road }\end{array}$ \\
\hline Requirements & $\begin{array}{l}\text { Environmental applicability assessed reliably: the concentrations and leaching of the } \\
\text { harmful substances not exceeding given limit values } \\
\text { Technical applicability assessed } \\
\text { Significant waste quantities } \\
\text { Functionality of material to be proven by pilot study (and full scale use) } \\
\text { Design manual for construction } \\
\text { Safety card }\end{array}$ \\
\hline Quality control & $\begin{array}{l}\text { Quality assurance system needed } \\
\text { Minimum testing programme } \\
\text { Use of standardized methods when possible }\end{array}$ \\
\hline $\begin{array}{l}\text { General guidelines } \\
\text { available for showing } \\
\text { compliance with } \\
\text { regulation? }\end{array}$ & Yes. Finnish background document (ref. see 2.3) \\
\hline
\end{tabular}

${ }^{13}$ Code of the waste in accordance with Ministry of the Environment Decree on the list of the most common wastes and of hazardous wastes (1129/2001). 
Table 21: Technical specification and environmental requirements

\begin{tabular}{|c|c|}
\hline Aspect & Requirement \\
\hline \multicolumn{2}{|l|}{ Construction specification } \\
\hline Max. height & $150 \mathrm{~cm}$; however, only a necessary quantity of waste shall be used \\
\hline Protection (pavement) & Two categories: covered and paved \\
\hline Distance to groundwater table & $\begin{array}{l}\text { Not specified: the structure containing waste shall not be in contact with } \\
\text { groundwater }\end{array}$ \\
\hline \multicolumn{2}{|l|}{ Others, specify } \\
\hline Distance to water well & $\begin{array}{l}\text { The minimum distance of the structure containing waste from a well or } \\
\text { spring intended for use as household water shall be } 30 \mathrm{~m}\end{array}$ \\
\hline Use on groundwater area & No \\
\hline $\begin{array}{l}\text { Exposure route included in } \\
\text { environmental impact assessment }\end{array}$ & Main focus on the release of harmful compounds to water \\
\hline Key properties regulated & Limit values given to leaching (CEN/TS 14005, EN 12457-3) content \\
\hline
\end{tabular}


Table 22: Limit values for content and release

\begin{tabular}{|c|c|c|c|c|c|c|}
\hline \multirow[t]{2}{*}{ Harmful substance } & \multicolumn{3}{|c|}{$\begin{array}{l}\text { Limit value, } \mathrm{mg} / \mathrm{kg} \text { of dry matter } \\
\text { Basic characterisations }{ }^{1}\end{array}$} & \multicolumn{3}{|c|}{$\begin{array}{l}\text { Limit value, } \mathrm{mg} / \mathrm{kg} \text { of dry matter } \\
\text { Quality control investigations }{ }^{1}\end{array}$} \\
\hline & Content & $\begin{array}{r}\text { Leaching } \\
(\mathrm{L} / \mathrm{S}=10 \mathrm{I} / \mathrm{kg}) \\
\text { Covered } \\
\text { structure }\end{array}$ & $\begin{array}{r}\text { Leaching } \\
(\mathrm{L} / \mathrm{S}=10 \mathrm{l} / \mathrm{kg}) \\
\text { Paved } \\
\text { structure }\end{array}$ & Content & $\begin{array}{r}\text { Leaching } \\
(\mathrm{L} / \mathrm{S}=10 \mathrm{l} / \mathrm{kg}) \\
\text { Covered } \\
\text { structure }\end{array}$ & $\begin{array}{r}\text { Leaching } \\
(\mathrm{L} / \mathrm{S}=10 \mathrm{I} / \mathrm{kg}) \\
\text { Paved } \\
\text { structure }\end{array}$ \\
\hline $\mathrm{PCB}^{2}$ & 1.0 & & & 1.0 & & \\
\hline $\mathrm{PAH}^{3}$ & 20 & & & & & \\
\hline Hydrocarbons ${ }^{4}$ & 500 & & & & & \\
\hline $\mathrm{DOC}^{5}$ & & 500 & 500 & & & \\
\hline Antimony (Sb) & & 0.06 & 0.06 & & & \\
\hline Arsenic (As) & 50 & 0.5 & 0.5 & 50 & & \\
\hline Barium (Ba) & & 20 & 20 & & & \\
\hline Cadmium (Cd) & 10 & 0.02 & 0.02 & 10 & 0.02 & 0.02 \\
\hline Chrome (Cr) & 400 & 0.5 & 0.5 & 400 & 0.5 & 0.5 \\
\hline Copper (Cu) & 400 & 2.0 & 2.0 & 400 & 2.0 & 2.0 \\
\hline Mercury (Hg) & & 0.01 & 0.01 & & & \\
\hline Lead $(\mathrm{Pb})$ & 300 & 0.5 & 0.5 & 300 & 0.5 & 0.5 \\
\hline Molybdenum (Mo) & & 0.5 & 0.5 & & & \\
\hline Nickel (Ni) & & 0.4 & 0.4 & & & \\
\hline Vanadium (V) & & 2.0 & 2.0 & & & \\
\hline Zinc (Zn) & 700 & 4.0 & 4.0 & 700 & & \\
\hline Selenium (Se) & & 0.1 & 0.1 & & & \\
\hline Fluoride (F-) & & 10 & 50 & & & \\
\hline Sulphate $\left(\mathrm{SO}_{4}{ }^{2-}\right)$ & & 1,000 & 6,000 & & 1,000 & 6,000 \\
\hline Chloride ( $\left.\mathrm{Cl}{ }^{-}\right)$ & & 800 & 800 & & & \\
\hline
\end{tabular}

Note: ${ }^{1}$ Determination of metal content: acid digestion and microwave assisted digestion in compliance with standard SFS-EN 13656 or digestion with aqua regia in compliance with standard SFS-EN 13657. For determining the leaching of harmful substances, the up-flow percolation test shall be used in compliance with draft standard CEN/TS 14405. For quality control purposes, the two-stage batch test in compliance with standard SFS-EN 12457-3 can also be used.

${ }^{2}$ Polychlorinated biphenyls, total quantity of congenerics 28, 52, 101, 118, 138, 153 and 180. For the determination of polychlorinated biphenyls (PCB), the method to be used shall comply with draft standard EN 15308.

${ }^{3}$ Polycyclic aromatic hydrocarbons, total amount of compounds (anthracene, ace-naphthene, acenaphthylene, benzo(a)anthracene, benzo(a)pyrene, benzo(b)fluoranthene, benzo(g,h,i)perylene, benzo(k)fluoranthene, dibenzo(a,h)anthra-cene, phenanthrene, fluoranthene, fluorene, indeno(1,2,3-c,d)pyrene, naphthalene, pyrene, chrysene).

${ }^{4}$ Hydrocarbon fractions C10-C40. Test method: EN 14039.

${ }^{5}$ Dissolved organic carbon. 


\section{Finnish studies regarding C\&D waste}

Since the mid 90's several national research programmes aiming to increase the use of waste materials in earth construction have been carried out.

\section{Finnish Ecogeo-technocology R \& D Program (1995-1999)}

- Funded by TEKES, the National Technological Agency shared with companies and other organisations:

- $10 \mathrm{ME}$.

- 70 projects (50 product developments, 20 research projects).

- Main areas:

- Remediation of contaminated soil.

- Protection of ground water.

- Processing of industrial by-products and surplus soil masses into recycled products for earth construction.

- Specific goals:

- Development of alternatives to traditional natural materials used in earth constructions made from by-products and wastes.

- Increase the use of alternative materials (establishment of test methods and acceptance criteria for the environmental and technical compliance).

- Suggestions for development of more adaptable legal measures.

- Results related to use of C\&D waste in earth construction:

- Several projects were carried out (including pilot construction, lifecycle assessment and environmental applicability).

- Publication of Finnish Standard SFS 5884.

- Collected information used as background information for the publication of Decision of State. 
UUMA (Advanced materials technology for infrastructure building) development programme 2006-2010

- Main areas:

- By-products and mineral wastes.

- Materials from old infrastructures.

- Surplus soil.

- (De)contaminated soils.

- Goals:

- Increase the use of recycled materials and by-products.

- Decrease the use of natural resources.

- Waste prevention in earth constructions.

- To coordinate projects financed by Ministry of the Environment, National Technology Agency TEKES, Finnish Road Administration, SITRA etc.

- Projects and activities by Finnish Ministry of the Environment:

- UUMA-report (2010) highlighting the legislative boundaries, approach for evaluation of environmental acceptability of byproducts in earth construction and analysis of some candidate waste streams for EoW-concept.

- International seminar: END OF WASTE FOR MINERAL RESIDUES - aspects of concern in earth construction, 25 November 2008 (note: seminar presentations available at http://thule.oulu.fi/uuma/seminar/). The objective of the Seminar was to address issues on using recycled materials and by-products as aggregates in earth constructions. The seminar provides different European legislative perspectives and practices and a forum for the exchange of information. Target group includes different operators from manufacturers to contractors, regulators, scientists and other professionals.

- Material specific workshops with invited stakeholders identification of knowledge gaps and legal barriers for use. 


\title{
Appendix 4: Management of C\&D waste in Norway
}

\author{
Recycling of C\&D waste in Norway
}

\section{Regulation and requirements}

The National goals for recycling in Norway is $75 \%$ of the total waste quantity in 2010. This includes however also metal recovery and incineration with recovery of energy.

To enhance the utilisation of C\&D waste it is required that C\&D projects must have a waste management plan - see Table 23 - ensuring that $60 \%(\mathrm{w} / \mathrm{w})$ of the waste shall be sorted into material fractions on site. Finalising the projects this requirement must be documented. For demolition/rehabilitation projects an environmental mapping must in addition be prepared beforehand in order to identify and handle hazardous waste.

In Norway the use of C\&D waste is not directly regulated by specific requirements or criteria, but a number of guidelines and standards related to road constructions may be of relevance.

Table 23: Requirement for information regarding waste management in C\&D projects

\begin{tabular}{|c|c|c|}
\hline Operation & Area criteria or amounts of waste & Requirements for information \\
\hline Construction of buildings & $>300 \mathrm{~m}^{2}$ & $\begin{array}{l}\text { Waste management plan. } \\
\text { Final report }\end{array}$ \\
\hline $\begin{array}{l}\text { Demolition and renovation of } \\
\text { buildings }\end{array}$ & $>100 \mathrm{~m}^{2}$ & $\begin{array}{l}\text { Mapping of environmental } \\
\text { hazardous substances } \\
\text { Waste management plan } \\
\text { Final report }\end{array}$ \\
\hline $\begin{array}{l}\text { Construction of constructions other } \\
\text { than buildings, as bridges etc. }\end{array}$ & $\begin{array}{l}\text { Generation of more than } 10 \text { tons } \\
\text { of waste }\end{array}$ & $\begin{array}{l}\text { Waste management plan } \\
\text { Final report }\end{array}$ \\
\hline $\begin{array}{l}\text { Renovation and demolition of } \\
\text { constructions other than buildings, } \\
\text { as bridges etc. }\end{array}$ & $\begin{array}{l}\text { Generation of more than } 10 \text { tons } \\
\text { of waste }\end{array}$ & $\begin{array}{l}\text { Mapping of environmental } \\
\text { hazardous substances } \\
\text { Waste management plan } \\
\text { Final report }\end{array}$ \\
\hline
\end{tabular}




\section{Declaration of recycled aggregates}

To establish confident on the quality of recycled aggregates from C\&D waste a declaration arrangement was proposed by RESIBA in 2002 (resirkulert tilslag for bygg og anlegg). It is not clear whether this arrangement is in use today or it has been in use. The content of proposed the declaration form is shown in Figure 6.

Figure 6: Suggestion for declaration form for recycled aggregates from C\&D waste (RESIBA 04/2002)

\begin{tabular}{|c|c|c|c|c|}
\hline \multirow[t]{2}{*}{ Testparameter } & \multirow[t]{2}{*}{ Provemetode } & \multirow{2}{*}{$\begin{array}{l}\text { Utfores } \\
\text { av (type } \\
\text { lab.) }\end{array}$} & \multicolumn{2}{|c|}{ Testfrekvens ved lopende kontroll } \\
\hline & & & $\begin{array}{l}\text { Materialer } \\
\text { til bunden } \\
\text { bruk (tilslag } \\
\text { til betong) }\end{array}$ & $\begin{array}{l}\text { Materialer til ubunden bruk } \\
\text { (mekanisk stabilisering) }\end{array}$ \\
\hline Kornfordeling & NS-EN 933-1 & $L^{1)}$ & \multicolumn{2}{|c|}{ Hver uke eller min. pr. 2000 tonn } \\
\hline $\begin{array}{l}\text { Finstoffinnhold }(\text { matr. }<0.063 \\
\text { mm av matr. }<19 \mathrm{~mm})\end{array}$ & NS-EN 933-1 & $L^{1)}$ & \multicolumn{2}{|c|}{ Hver uke eller $\min$. pr. 2000 tonn } \\
\hline $\begin{array}{l}\text { Innhold av matr. }<0,020 \mathrm{~mm} \\
\text { regnet av matr. }<19 \mathrm{~mm}\end{array}$ & $\begin{array}{l}\text { Handbok } 014 \\
\text { pkt. } 14.434\end{array}$ & $L^{\mathrm{I}}$ & - & Ved krav \\
\hline Materialsammensetning ${ }^{3)}$ & prEN 933-11 & $L^{1)}$ & \multicolumn{2}{|c|}{ Hver uke eller min. pr. 2000 tonn } \\
\hline $\begin{array}{l}\text { Organisk materiale } \\
\text { (humus) }\end{array}$ & NS-EN $1744-1$ & $L^{13}$ & $\begin{array}{l}\text { Hver uke } \\
\text { eller min. pr } \\
\text { uke. } 3000 \\
\text { tonn }\end{array}$ & - \\
\hline $\begin{array}{l}\text { Komform (av matr. }>8 \mathrm{~mm} \text { ) } \\
\text { (flisighetsindeks) }\end{array}$ & NS-EN 933-3 & $\mathrm{L} / \mathrm{S} / \mathrm{E}^{2}$ & \multicolumn{2}{|l|}{ Hver måned } \\
\hline $\begin{array}{l}\text { Mekaniske egenskaper } \\
\text { (Los Angles) }\end{array}$ & EN 1097-2 & $\mathrm{L} / \mathrm{S} / \mathrm{E}^{2}$ & - & $\begin{array}{l}\text { Hver } 2 \text {. uke eller } \min \text {. hver } \\
10000 \text { tonn }\end{array}$ \\
\hline Densitet & EN 1097-6 & \begin{tabular}{|l|l|} 
& \\
\end{tabular} & \multicolumn{2}{|c|}{ Hver 2. uke eller min. hver 10000 tonn } \\
\hline Vannabsorpsion & EN 1097.6 & $L / S / E^{2)}$ & \multicolumn{2}{|c|}{ Hver 2. uke eller min. hver 10000 tonn } \\
\hline Kloridinnhold ${ }^{3}$ & NS-EN 1744-1 & $\mathrm{L} / \mathrm{S} / \mathrm{E}^{2}$ & $\begin{array}{l}\text { Hver } 2 \text {. uke } \\
\text { eller min. } \\
\text { hver } 10000 \\
\text { tonn }\end{array}$ & Ved krav \\
\hline Innhold av sulfater & NS-EN 1744-1 & $\mathrm{L} / \mathrm{S} / \mathrm{E}^{2)}$ & Ved krav & Ved krav \\
\hline $\begin{array}{l}\begin{array}{l}\text { Kjemisk analyse } \\
\text { (utlekking) }\end{array} \\
\end{array}$ & EN 1744-3 & $\mathrm{G}^{3}$ & - & $\begin{array}{l}\text { Hver } 2 \text {. uke eller } \min \text {. hver } \\
10000 \text { tonn }\end{array}$ \\
\hline
\end{tabular}

L Bor utfores lokalt (pá produksjonsstedet) med bakgnunn i muligheten for à styre produksjon basert pá

2) LS/E Kan utfores lokalt, sentralt eller eksternt.

3) G Skal utfores ved laboratorium godkjent for formilet.

4) Alternative metoder for vurdering av kjemisk analyse kan aksepteres

5) Testfrekvensen kan halveres dersom det er utfort forhảndsbesiktigelse iht. NB Publikasjon nr. 26. 


\section{Types and amounts of C\&D waste recycled}

The types and amounts (2007) of C\&D waste recycled in Norway are listed in Table 24.

\begin{tabular}{|c|c|c|c|}
\hline Type of waste & $\begin{array}{l}\text { Amounts } \\
\text { (tonnes) }\end{array}$ & Recycling purposes & References \\
\hline Concrete and tiles & $\begin{array}{l}100,000 \\
258,000 *\end{array}$ & Filling materials and aggregates & $\begin{array}{l}\text { Personal communication with Jon } \\
\text { Fonnlid Larsen from the Climate } \\
\text { and Pollution Agency in Norway }\end{array}$ \\
\hline Asphalt & 720,296 & $\begin{array}{l}\text { Recirculated in the asphalt produc- } \\
\text { tion and used for road construction }\end{array}$ & www.asfaltteknisk.no/kfa \\
\hline Siporex & $?$ & Filling materials & \\
\hline Leca & $?$ & Filling materials & \\
\hline Wood chips & $?$ & & \\
\hline Glass & ? & Isolating properity & \\
\hline
\end{tabular}

Note: * Reported as unspecified treatment. However, it is known that a significant part of this is used as filling materials.

Tiles may be demolished individually and reused without further treatment. However, profitability is the limiting factor.

Concrete and tiles are most often crushed by mobile facilities on the demolition site with the aim of using the materials as fillers.

Permanent facilities for recovery of resources also receive waste from demolition projects. Concrete and tiles are crushed; metal pieces are removed by a magnet and light fractions as paper, plastic and wood by an air blower fan.

Before demolition and rehabilitation projects are initiated, the presence of environmentally hazardous substances shall be addressed in order to prevent pollution of materials for utilisation. The substances of concern are listed in Table 25. 
Table 25: Constituents of environmental concern in C\&D materials

\begin{tabular}{|c|c|}
\hline C\&D materials & Constituents of concern \\
\hline "Painted" materials & $\begin{array}{l}\text { Asbestos*, azo-arenes, isocyanates, cadmium, chlorinated phenols, mercury, } \\
\text { zink, lead, dioxan 1,4, phthaletes, chlorinated parafins, chromium, PCB }\end{array}$ \\
\hline Tiles & Asbestos* \\
\hline Outdoor front tiles & Phenol \\
\hline Glazed tiles & Lead \\
\hline Sealants & Lead, PCB, polyacrylates, phthalater, chlorinated parafins \\
\hline Chimney pipe & Lead \\
\hline \multirow[t]{2}{*}{ Concrete } & Dioxan 1,4 \\
\hline & Chromium \\
\hline Asphalt & PAH \\
\hline
\end{tabular}

Note: * Asbestos is not hazardous to the environment but to human health.

Source: Engelsen et al. 2002.

In March 2010 a new study with the aim of mapping new fractions of hazardous waste in C\&D waste was completed (Norconsult, 2010). The main results from the project were:

- It is likely that hard polyurethane produced up until 2003 contains CFC/HCFC gases. This material is found in garage doors, prefabricated walls for refrigeration rooms and prefabricated insulated outer walls, for example in pre-fabricated warehouses.

- Vinyl flooring may contain a number of environmental contaminants, such as phthalates, asbestos, lead and, in some cases PCB. In most cases flooring produced after 2000 is not hazardous waste.

- Skirting boards of PVC almost always contain a measurable of phthalates and above the limit for hazardous waste. Vinyl flooring from both demolition and rehabilitation is often treated as residual waste today. Flooring should first be analysed and, if found to contain phthalates, disposed of accordingly.

- Roofing, folding walls and chair seats of soft PVC-sheets produced before 2000 may also contain hazardous waste levels of phthalates and lead.

- Double-glazed windows produced after the "PCB period" may contain relatively large quantities of chlorinated paraffins, chiefly in 
the glue and the rubber mouldings. The production period from 1975 to 1990 appears to the period with largest the proportion of double-glazed windows containing chlorinated paraffins.

- Insulation of cellular rubber produced before 2004 is often a hazardous waste because of brominated flame retardants' levels. It may also contain other environmentally dangerous substances.

- Cable housings of plastic may contain quantities of lead above the limit of hazardous waste.

\section{Environmental quality data on C\&D waste}

Norwegian studies were performed in 2002 to assess the environmental impact caused by recycling of aggregates from C\&D waste. The results were published in reports from Byggforsk (Engelsen et al., 2002, Myhre et al., 2003, Petkovic and Lillestøl, 2002). Table 26 provides an overview of the type of data available from these studies.

\begin{tabular}{|c|c|c|}
\hline Types of materials & Material specifications & Type of data available \\
\hline \multirow[t]{3}{*}{ Mixed materials } & $0-10 \mathrm{~mm}$ & Leaching (prEN 1744-3). Total content \\
\hline & $10-20 \mathrm{~mm}$ & Leaching (prEN 1744-3). Total content \\
\hline & $10-38 \mathrm{~mm}$ & Leaching (prEN 1744-3) \\
\hline \multirow[t]{2}{*}{ Concrete } & $0-10 \mathrm{~mm}$ & Leaching (prEN 1744-3) \\
\hline & $10-20 \mathrm{~mm}$ & Leaching (prEN 1744-3) \\
\hline Aggregates from C\&D & $10-20 \mathrm{~mm}$ & $\begin{array}{l}\text { Field study. Aggregates utilised for basement in } \\
\text { road construction and filling in open ditches }\end{array}$ \\
\hline
\end{tabular}

It should be noted that the leaching test method used to address the leaching properties (prEN1744-3) has been severely criticised by international experts. The criticism is mainly related to the undefined particle size of the test material which in terms of release provides an undefined mix between dissolution and diffusion phenomena). Thus the leaching results from this test method are not discussed further.

Examples of results from analysis of total content are given in Table 27. 
Table 27: Total content in $\mathrm{mg} / \mathrm{kg}$ of critical contaminants in mixed aggregates from C\&D waste

\begin{tabular}{|c|c|c|c|c|}
\hline \multirow[t]{3}{*}{ Contaminants } & Sample 1 & Sample 2 & Sample 1 & Sample 2 \\
\hline & $0-10 \mathrm{~mm}$ & $0-10 \mathrm{~mm}$ & $10-20 \mathrm{~mm}$ & $10-20 \mathrm{~mm}$ \\
\hline & $\mathrm{mg} / \mathrm{kg}$ & $\mathrm{mg} / \mathrm{kg}$ & $\mathrm{mg} / \mathrm{kg}$ & $\mathrm{mg} / \mathrm{kg}$ \\
\hline As & 2.9 & 1.3 & 3.1 & 1 \\
\hline $\mathrm{Pb}$ & 17 & 15 & 9 & 6 \\
\hline $\mathrm{Cd}$ & 0.2 & 0.2 & $<0.1$ & $<0.1$ \\
\hline $\mathrm{Cu}$ & 17 & 16 & 18 & 15 \\
\hline $\mathrm{Cr}$ & 82 & 74 & 65 & 72 \\
\hline $\mathrm{Hg}$ & 0.04 & 0.05 & 0.02 & 0.01 \\
\hline $\mathrm{Ni}$ & 19 & 20 & 20 & 20 \\
\hline $\mathrm{Zn}$ & 137 & 121 & 71 & 64 \\
\hline $\mathrm{PCB}$ & 0.013 & 0.013 & 0.017 & 0.03 \\
\hline PAH & 3.26 & 3.1 & 19.8 & 0.74 \\
\hline
\end{tabular}

Source: Engelsen et al., 2002.

\section{Functional criteria}

National guidelines from "Statens Vegvesen" (handbook 018, 2005) This guideline has excisted since 1960s and with regularly revisions it represents the best practices. With it latest revision from 2005 recycling of C\&D waste materials in road construction is now included with requirements and guidelines for recycling of concrete and asphalt. Figure 7 provides a list of specific functional criteria for utilisation of concrete in the basement.

Figure 7: Criteria for recycled concrete aggregates in construction of road base

\begin{tabular}{|c|c|c|c|c|}
\hline \multirow[t]{2}{*}{ Krav til } & \multicolumn{3}{|c|}{ Kvalitetskrav } & \multirow{2}{*}{$\begin{array}{l}\text { Kontrollomfang } \\
\text { Min. } 1 \text { prøve } \\
\text { for hver } \\
\text { mengdeenhet }\end{array}$} \\
\hline & Krav & $\begin{array}{c}\text { Tole- } \\
\text { ranser 5) }\end{array}$ & $\begin{array}{l}\text { Maks. } \\
\text { avvik }\end{array}$ & \\
\hline \multicolumn{5}{|l|}{ Gjenbruksbetong } \\
\hline Los Angeles-verdi, øvre forsterkn.lag & $\leq 352)$ & $20 \%$ & +5 & 6) \\
\hline Los Angeles-verdi, nedre forsterkn.lag & $\leq 40$ & $20 \%$ & +5 & 6) \\
\hline Maks. pass. $63 \mu \mathrm{m}$ av mat. $<20 \mathrm{~mm}$ & $8 \% 8)$ & $20 \%$ & $+2 \%$ & $\left.1000 \mathrm{~m}^{3} 7\right)$ \\
\hline Graderingstall $C_{u}$ - øvre forsterkn.lag & $\geq 15^{1)}$ & $20 \%$ & -3 & $\left.1000 \mathrm{~m}^{3} 7\right)$ \\
\hline Graderingstall $C_{u}$ - nedre forsterkn.lag & $\geq 52$ & $20 \%$ & -1 & $\left.1000 \mathrm{~m}^{3} 7\right)$ \\
\hline Storste steinstørrelse & $\leq 120 \mathrm{~mm}$ & $20 \%$ & $20 \mathrm{~mm}$ & $\left.1000 \mathrm{~m}^{3} 7\right)$ \\
\hline Komprimering (Modifisert Proctor) & Figur 520.6 & Fig. 520.6 & $\geq 95 \%$ & $100 \mathrm{~m}$ veg ${ }^{4) 10}$ \\
\hline
\end{tabular}

Source: Statens Vegvesen, handbook 018. 
Granulates of asphalt can be recycled in road construction. Figure 8 shows the requirement for documentation (hot recycling).

Another guideline that provides guidance on testing of aggregates in general are Håndbok 014 "Laboratorieundersøkelser". This handbook does however not deal with recycled aggregates.

Figure 8: Requirements for documentation in relation to recycling of asphalt as aggregates

\begin{tabular}{|l|c|c|c|}
\hline Dokumentasjon av: & \multicolumn{3}{|c|}{ Tilsetning av asfaltgranulat } \\
\hline Slitelag & $<15 \%$ & $15-25 \%$ & $>25 \%$ \\
Bærelag & $<25 \%$ & $25-35 \%$ & $>35 \%$ \\
\hline Forurensninger 1) & oppgis & oppgis & oppgis \\
Bindemiddelinnhold & - & oppgis & oppgis \\
Gradering (ekstrahert) & - & oppgis & oppgis \\
Steinmaterialegenskaper & - & - & oppgis \\
Bindemiddelhardhet (penetrasjon) & - & - & oppgis \\
\hline
\end{tabular}

1) Forurensninger er fremmedstoffer som betong, tegl, tre, miljøgifter mv.

Source: Statens Vegvesen, handbook 018.

\section{Standards of relevance}

Standards (national and international) related to aggregates addresses a number of quality requirements related to properties such as geometry, size, grading, shape of particles etc.:

- NS 3420: Beskrivelsestekster for byg, anlegg, installasjoner. Del I5 Fundamenter for veier, baner og plasser.

- EN 13285: Unbound mixtures - Specifications.

- EN 13286: Unbound and hydraulically bound mixtures Test methods.

- NS-EN 13242: Aggregates for unbound and hydraulically bound materials for use in civil engineering work and road construction.

- NS-EN 13043: Aggregates for bituminous mixtures and surface treatments for roads, airfields and other trafficked areas.

- NS-EN 13620: Aggregates for concrete. 



\title{
Appendix 5: Management of C\&D waste in Sweden
}

\author{
Recycling of C\&D waste in Sweden
}

\section{Regulations and requirements}

General tendencies and political developments in Sweden concerning secondary aggregate materials

Today, about 100 million tonnes of aggregate material are used annually in Sweden. The road construction industry is responsible for about half of this. Natural gravel and rock material of good quality is easily accessible in Sweden and there is a long tradition for road construction with unbound materials. However, as in other sectors, sustainable management of resources has commenced. This has resulted in the introduction of alternative aggregate materials, such as recycled aggregates or various industrial residues. Alternative techniques such as the use of bound layers and stabilisation are also making progress in order to achieve cost-effective and resource saving constructions. The background to this is a number of political objectives and control instruments together with administrative and technical measures. The overall idea is that it should be a matter of course to use alternatives when possible and thus decrease landfill and reduce extraction from gravel pits and rock quarries. In this way, the use of alternative materials prolongs the life of existing landfills and reduces the need for new pits and quarries. The Swedish environmental protection procedures are illustrated in Figure 9. 


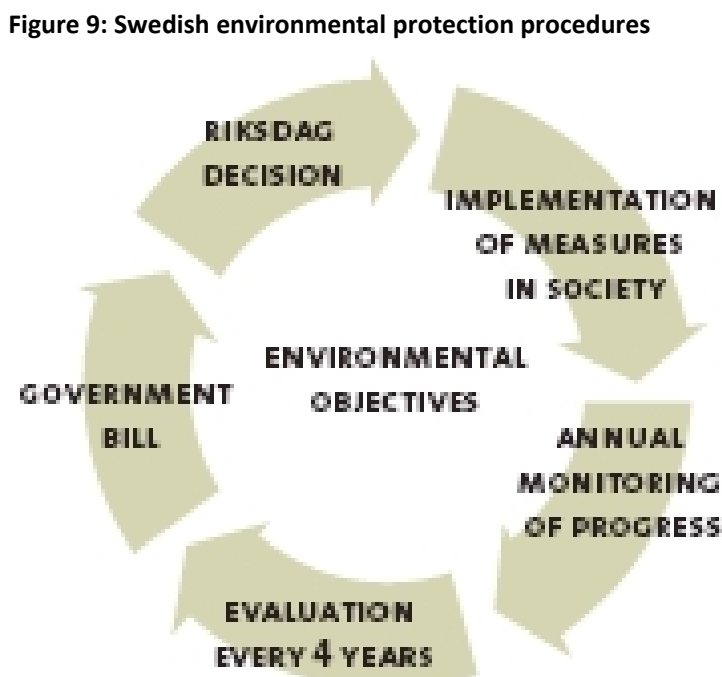

Sweden has set goals for the future state of its environment - Swedish Environmental Objectives - adopting 16 environmental quality objectives, describing the state of the Swedish environment that would be necessary to achieve sustainable development within our generation. For guidance, interim targets for each objective have been adopted, indicating the directions and timescale of the actions to be taken. Implementation of the objectives is reviewed every year and new and revised targets and measures are evaluated every fourth year.

Two interim targets relate directly to recycling and reuse of waste aggregates:

- "The total quantity of waste generated will not increase and maximum use will be made of its resource potential while minimizing health and environmental effects and associated risk...". This target is judged to be achievable if further vigorous measures are taken. So far, the disposal of industrial and construction waste has decreased substantially, partially due to the Waste Tax and the Ban on landfilling of combustible waste.

- "By 2010 the extraction of natural gravel in the country will not exceed 12 million tonnes per year". However, in 2008 the corresponding figure was 18.8 million tonnes and the forecast says it will be hard to achieve the target. 
Three action strategies have been drawn up to cover the activities in society that give rise to the majority of today's environmental problems:

- More Efficient Energy Use and Transport.

- Non-Toxic, Resource-Saving Environmental Life Cycles.

- Management of Land, Water and the Built Environment.

The structure of the Swedish environmental objectives is currently going thru a major revision (Swedish Parliament, 2009). Changes have been made regarding the Nontoxic environment objective. Goods and products are to be considered in a life-cycle perspective from the choice of raw materials to the final management of waste. Phase-out of hazardous substances will improve the possibilities of recycling and reuse and prevent emissions of hazardous substances.

Sweden's Waste Plan sets out the course of the waste management. The aim is to produce as little waste as possible. Where waste does arise, the source it represents in the form of materials or energy should be used as efficiently as possible. At the same time, the environmental impact of waste treatment in the form of emissions should be minimised. The national environmental quality objectives form the basis for what may be considered to be environmentally sustainable waste management (Swedish EPA 2006). Work on a new Waste Plan is ongoing (Swedish EPA 2010a) where the management on C\&D waste has been given priority due to

- the potential of increased recovery

- the presence of a significant amount of hazardous waste

- the presence of a recycling target in the new Waste Frame Directive

- the need for improved supervision and statistics.

\section{Waste tax and tax on natural gravel}

A political control instrument contributing to European waste frame directive thematic strategy on the prevention and recycling of waste is the Waste Tax. The tax of waste deposited on landfill sites was introduced in the year 2000. Since then it has gradually been increased, to approximately EUR 41.3 per tonne as from January 2006. For deposited material that is reused in some way, in road construction for example, the waste tax is repaid. Some waste categories are exempted, such as waste at landfill sites for excavated inert waste, mining waste, steel slag and blast furnace slag. On the other hand, incinerator ash, reclaimed asphalt as well as construction and demolition waste are affected by the tax. 
Swedish deposits of natural gravel are of great value for the drinking water supply and the natural and cultural landscape. In 1996 a tax on natural gravel was introduced. Since 2006 the tax is approximately EUR 1.2 per tonne of gravel extracted. It is the gravel producer that pays the tax. Over the years, natural gravel has more and more been replaced by crushed rock in aggregate production. The reason is mainly increased requirements on road aggregates and restrictions in new licenses for gravel pits.

\section{Regulations and guidelines}

The European Waste Frame Directive is implemented in The Environmental Code (SFS 1998:808) and Swedish Ordinance of Waste (SFS 2001:1063). The fundamental backbone of the environmental code are the eight general rules of consideration which concerns any activity or measure that may have environmentally impact: The reverse burden of proof principle; The knowledge requirement; The precautionary principle; The polluter pays principle; The BAT principle; The appropriate location principle; The resource management and ecocycle principle and The product choice principle.

Demolition of buildings is regulated under the Planning and Building Act in order to promote recovery and secure the handling of hazardous waste. Swedish EPA has published a web-based guidance (Swedish EPA 2010) on the management of demolition waste from buildings. Demolition normally has to be notified to the municipal council and a plan for demolition included. The plan for demolition shall always contain any materials that are hazardous waste and often an inventory of the amount, type and selective treatment of non-hazardous waste. Detailed guidance on C\&D waste handling has been published by The Ecocycle Council an association within the Swedish building and real estate sector (The Ecocycle Council 2007) and Stockholm City (Stockholm City Environment and Health Administration 2006).

The selective removal of PCB-containing material in buildings in regulated is the Ordinance on PCB (SFS 2007:19). Inventories for the presence of PCB in caulking (windows and expansion joints) or floorings shall be performed for buildings built or refurbished year 1956-1973. If the material is contaminated at a $500 \mathrm{ppm}$ level remediation measures are required due to 2016 at latest.

The selective removal of asbestos containing materials is performed to ensure workers health and regulated in AFS 1996:13.

Some trademarks of lightweight concrete in Sweden - "blue concrete" - give off small amounts of radioactive radon. Recycling as a building material or recovery as an aggregate in building foundations should be 
avoided (SSM 2001). Recovery as aggregates in roads or backfilling is recommended (the Ecocycle Council 2007) and common (SMM 2009) and guideline values on radiation that admit this use are proposed in an ordinance submitted for consideration (SMM 2010a).

The use of waste for construction purposes is an environmentally hazardous activity under the Ordinance on Environmentally Hazardous Activities and Public Health (SFS 1998:899). Depending on the risk, the activity must be notified to the municipal council or licensed by the county administrative board.

Recovery of waste in constructions requires licensing in the case of "more than a minor risk" of pollution of land or water and notification in case of "a minor risk". There is guidance but no limit values on how to distinguish between more than a minor and minor risk. Notification and licensing is to be established on a case by case risk assessment. The following characteristics are to be taken in account:

- The hazardous properties of the material.

- The construction and its effects on probable emission and exposure.

- The location of the construction and the sensitivity of the environment.

Regulations related to pre-treatment or temporary storage of waste before use in building and construction is presented in Table 28.

\begin{tabular}{|c|c|c|c|c|c|}
\hline \multirow[t]{2}{*}{ Type of permit } & \multicolumn{3}{|c|}{ Non-hazardous waste } & \multicolumn{2}{|c|}{$\begin{array}{l}\text { Hazardous waste recycling of } \\
\text { contaminated soil }\end{array}$} \\
\hline & $\begin{array}{l}\text { Temporary } \\
\text { storage }^{1}\end{array}$ & $\begin{array}{l}\text { Mechanical pre- } \\
\text { treatment (e.g. } \\
\text { crushing) }\end{array}$ & Sorting & $\begin{array}{l}\text { Facility for } \\
\text { treatment }\end{array}$ & $\begin{array}{l}\text { On site treatment and } \\
\text { recycling }\end{array}$ \\
\hline Licensing & $>30,000 \mathrm{t}$ & $>10,000 \mathrm{t}$ & - & No limit & $\begin{array}{l}\text { Treatment period exceeds } \\
1 \text { year }\end{array}$ \\
\hline Notification & $>10 t$ & No limit & $3,000 t$ & - & No limit \\
\hline
\end{tabular}

Note: ${ }^{1}$ Temporary storage before recycling is limited to less than 3 years.

The administrative burden, the time delay and the uncertainty in the outcome associated with licensing and notification can counteract the recycling of materials classified as waste. Consequently, criteria for "minor risk" and "end of waste" have been discussed extensively. Guidelines and handbooks have been published by many authorities and organisations. 
The Swedish EPA provides guidance to supervisory authorities on waste recycling in construction works and may in some cases take part in the permitting process. In 2006 Swedish EPA was given a commission by the government to define criteria's on reuse of waste in construction in order to increase the recycling of waste while preventing risk for negative environmental and health effects.

The Swedish EPA has recently published guidance in a handbook for utilisation of waste in construction works (Swedish EPA 2010c). The handbook gives guidance on utilisation of waste as construction material in a safe manner for environment and human health. Legislation that applies for utilisation of waste as construction material and the relation to the national environmental objectives is described. The handbook provides guidance for the supervision authorities when handling notifications and applications for waste utilisation and it describes necessary information for the assessment.

In the handbook also provides guidance on what can be considered as a pollution risk that is less than minor when it comes to waste recycling in construction works. Pollution levels for "less than minor risk" are presented in the handbook - when there are no restrictions for use and that no notification to the municipal board is necessary. Levels are also presented for utilisation when the waste is used in the top cover of a landfill. Levels are presented for content as well as leaching properties for 13 substances that are often the most critical ones in waste.

Guideline for "less than minor risk" values are strict (based on natural background values for some phase-out substances) so that the use does not result in new contaminated sites or that contaminants are leaching where it cannot be controlled in the future Swedish EPA has accounted for these guideline values as an input to "end of waste" criteria in the Aggregates Case Study (Austrian EA 2008). These guideline values do not apply to bound materials e.g. asphalt pavements.

\section{Types and amounts of C\&D waste utilised}

\section{Primary aggregate production and use}

Pits, quarries and mobile crushers for aggregate production generally require licensing or notification (SFS 1998:899) and data on production are reported to the regional county administration. A detailed yearly report on aggregate production and use is put together by The Geological Survey of Sweden (SGU). Figures from the most recent report (SGU 2009) are given in Table 29. Large scale infrastructure projects generate substantial quantities of crushed rock aggregates from mobile crushers specially in 
the case of tunnelling. The localisation of these production sites varies with the localisation of the infrastructure projects. The high demand for aggregates, scarce recourses and sizeable traffic loads in larger cities are incentives for recycling of secondary aggregates (Svensk Bergs- \& Brukstidning, 2010). A study on the future aggregate supply in the Stockholm County is in progress (Toller, 2010).

Concrete production is responsible for a large part of the use of natural sand and gravel, $40 \%$. This use is difficult to replace due to technical and quality requirements (SGU 2009).

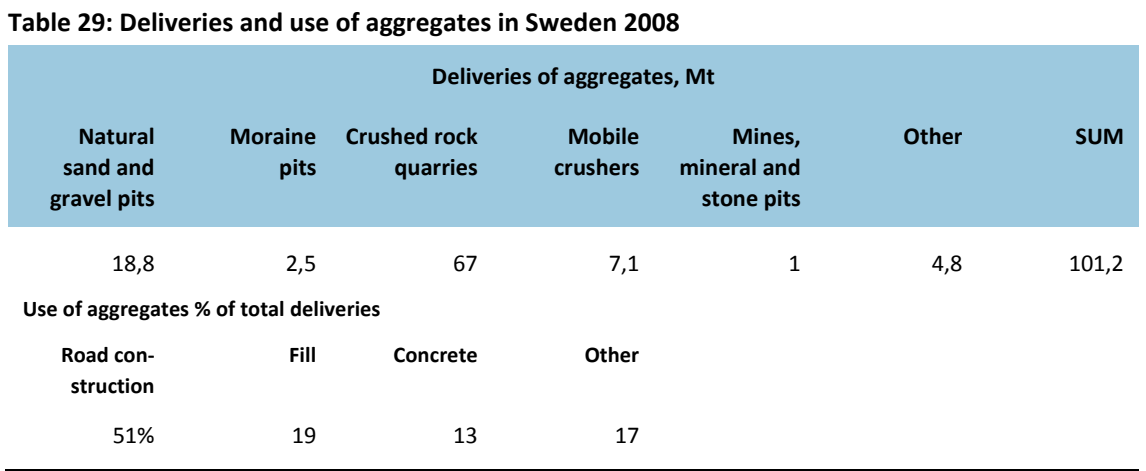

\section{Secondary aggregate production and use}

Swedish statistics on aggregate production do only include aggregate production based on rock or natural sand, gravel and moraine. There are today no reliable Swedish yearly statistics on the production of secondary aggregates, e.g. waste that can be used to replace aggregates.

The generation and use of secondary aggregates from industrial sources have been surveyed in a number of reports (Wik et al. 2003, Svenska Energiaskor 2006, SGI 2007, Jernkontoret 2009). Additional but uncertain figures for C\&D waste can be extracted from the Swedish waste report (Swedish EPA, 2010c, Nordin, A., 2010). Recovery of anti skid materials has been reported by Swedish Association of Local Authorities and Regions (2008). The annual generation and use of potential secondary aggregates estimated from these sources is shown in Table 30. 
Table 30: Generation and use of potential secondary aggregates in Sweden in Mt/year ${ }^{1}$

\begin{tabular}{|c|c|c|}
\hline Material & Generation (Mt/year) & Recovery (Mt/year) \\
\hline Ash from incineration & 1.3 & 1 \\
\hline Mining industries & 60 & 0.3 \\
\hline Quarrying industries & 2 & \\
\hline Metallurgic industry ${ }^{2}$ & 1.8 & 1.7 \\
\hline Foundry & 0.18 & 0.16 \\
\hline Pulp and Paper (excluding ash) & 0.3 & 0.15 \\
\hline Other (e.g. shredded tyres, glass) & 0.15 & 0.1 \\
\hline Construction and Demolition ${ }^{3}$ & $2-2.5 ?$ & 1.4 ? \\
\hline Anti-skid materials (gravel and sand) & 0.750 & $0.750 ?$ \\
\hline
\end{tabular}

Note: ${ }^{1}$ Sludges that are use in landfill covers or for production of compost are not included.

${ }^{2}$ For many of the materials that are generated in the metallurgic industry REACH registration is ongoing and these might thus be classified as by-products in the future.

${ }^{3}$ Statistics on secondary aggregates from construction and demolition is highly uncertain. Clean soils are not included.

Higher requirements on landfill design has resulted in the closure or upgrading of many Swedish landfills. This has resulted in a high demand for aggregates and filling materials to be used in the levelling and covering of landfills. In some regions a shortage of conventional aggregates is expected during the next years (Engström, H. \& Ulwan, Å., 2005). The current extensive use of secondary aggregates in landfill covers (Swedish EPA 2010c) is consistent with the high recovery rates reported for some of the materials in table 4.7.3. This number of filed application is expected to decrease substantially within 5 years (Grönholm, 2010) and might result in considerably lower recovery rates.

Several guidelines and handbooks on the recovery of secondary aggregates from the industrial sector in constructions has been published e.g. by the Swedish Road Administration (2007a) and SGI (2006).

It is difficult to obtain reliable statistical data for the construction and demolition sector, and no useful figures on waste that can be used as secondary aggregates are available in Swedish waste statistics (SMED, 2009, Swedish EPA, 2010c, Nordin, A., 2010). One reason for this is ambiguousity in the waste definition, especially in the infrastructure sector. Large quantities of technically unfit soils are often excavated and removed during foundation of buildings or constructions. These can be recovered at site for landscaping or other low quality technical purposes such as noise screens. But in cities and densely populated areas the lack of space often leads to removal from the site. Clean soils ${ }^{14}$ are now excluded from the Swedish

14 There is no definition of the term clean in the waste statistics. 
waste statistics (Swedish EPA, 2010c) which resulted in a drastic reduction of the mineral waste figures compared to earlier reports

Guidelines on the selective treatment of non-hazardous waste fractions of C\&D waste (The Ecocycle Council, 2007) identify the following material categories that can be recovered as aggregates: Rock, bricks, concrete, concrete with reinforcement bars, lightweight concrete, other mineral materials (e.g. tiles, ceramics, sanitary goods, mortar), clean soil, excavated fill and asphalt.

Interviews with two actors in the construction waste recycling/reclamation sector gave indications on the recovery of C\&D aggregates presented in Table 31. It seems that the recovered C\&D aggregates represent less than $10 \%$ of the production of primary aggregates which is in agreement with other studies (Vaivars, in press).

\begin{tabular}{|c|c|c|}
\hline Material & Malmö Area. (Tell R 2010) & $\begin{array}{l}\text { Stockholm/Uppsala regional Area. } \\
\text { (Andersson, 2010) }\end{array}$ \\
\hline Concrete & $30 \%^{1}$ & $30 \%$ \\
\hline Mixed Concrete/Bricks & $30 \%$ & \\
\hline Asphalt & $30 \%$ & $60 \%$ \\
\hline Non-cohesive soil & $10 \%$ & $10 \%$ \\
\hline Quality check & $\begin{array}{l}\text { Ocular examination, recycled } \\
\text { asphalt are sampled and analysed }\end{array}$ & $\begin{array}{l}\text { Handheld field analytical instru- } \\
\text { ments (XRF, PID). Materials have to } \\
\text { be traceable with respect to origin }\end{array}$ \\
\hline $\begin{array}{l}\text { Estimated total secondary C\&D ag- } \\
\text { gregates within the region }\end{array}$ & $0,2-0,3 \mathrm{Mt} /$ year & 1,5-2 Mt/year \\
\hline $\begin{array}{l}\text { Virgin aggregate production within } \\
\text { the region (from SGU 2009) }\end{array}$ & ca $5 \mathrm{Mt} /$ year & ca $17 \mathrm{Mt} /$ year \\
\hline
\end{tabular}

Note: ${ }^{1}$ Concrete is only accepted if it is free from surface treatments e.g. paint.

\section{Concrete}

Some trademarks of lightweight concrete in Sweden - "blue concrete" - was produced from alum slate until 1975, which makes the material give off small amounts of radioactive radon. Large amounts, ca $20,0000,000 \mathrm{~m}^{3}$, of "blue concrete" is estimated to be installed in buildings (SMM 2010a). The generation and recycling of crushed concrete in Sweden has been estimated to be $1.2-1$ Mt and $0.72-0.68$ Mt respectively with more than $90 \%$ being used in unbound applications below ground (Engelsen et al., 2005). It is noted though that there is very little data available. 
Experiences and requirements on recovery of C\&D concrete in roads on a European level is being addressed in the ongoing DirectMat project (DirectMat, 2010). Swedish experiences have been summarized in a literature review that will be published at the DirectMat home page.

Requirements for use of crushed concrete in new unbound road layers are published by the Swedish Road Administration in (SRA, 2004a). In the specifications, crushed concrete is classified into quality classes depending on concrete quality and amount of impurities and to these classes are assigned different design moduli (Table 32). If stiffness increase properties can be proved, an even higher modulus value may be used.

Table 32: Quality classes of crushed concrete for use in unbound road layers according to Swedish specifications

\begin{tabular}{|c|c|c|c|c|}
\hline Class & 1 & 2 & 3 & 4 \\
\hline Design modulus & $450 \mathrm{MPa}$ & $450 \mathrm{MPa}$ & $250 \mathrm{MPa}$ & $150 \mathrm{MPa}$ \\
\hline \multicolumn{5}{|l|}{ Constituent } \\
\hline Concrete & $100 \%$ & $\geq 95 \%$ & $\geq 80 \%$ & $\geq 50 \%$ \\
\hline Masonry & & $\leq 5 \%$ & $\leq 20 \%$ & $\leq 50 \%$ \\
\hline Lightweight concrete & & $\leq 1 \%$ & $\leq 5 \%$ & $\leq 50 \%$ \\
\hline $\begin{array}{l}\text { Other foreign materials e.g } \\
\text { wood, plastics, bitumen. }\end{array}$ & & $\leq 0.5 \%$ & $\leq 2 \%$ & $\leq 10 \%$ \\
\hline
\end{tabular}

Quality classes 1 and 2 meet the requirements of unbound base and subbase of roads. The lower quality class 3 can be used as sub-base in cycle ways and foot paths. Class 4 is usually only used in simpler tasks as filling.

In the nineties, several research projects were performed in Sweden regarding the use of crushed demolition concrete in road constructions. They included both laboratory tests and field tests. In the laboratory, the following properties were determined: The results from this research are published in many reports, but summarised and referred to in (Ydrevik, 1999) and (Arm, 2007) and they have served as bases for the present national requirements described in (SRA, 2004a).

The origin and handling of the concrete influence the mechanical properties of the crushed material. Porous cement as well as foreign weak particles, such as lightweight concrete and brick, but also wood, plaster and reinforcement, reduces quality. Particle size distribution with a large maximum particle size as well as a well-graded curve is positive, as is the case for natural aggregates. Stiffness increase in unbound layers of crushed concrete.

Both laboratory and field results have shown an increase in stiffness for unbound layers with crushed concrete, which is not present for unbound layers with natural aggregates. This increase is considerably 
larger in the field tests than in the laboratory test. The increase is greatest during the first months and then diminishes. This means that the layer modulus two years after construction can be about twice as high as the level after one month.

Crushed concrete has lower resistance than gravel and crushed granite when tested with standardised mechanical laboratory methods like LA. The concrete material produces greater proportion of fines and is subject to greater disintegration. The resistance to mechanical impact depends on particle shape and indirectly on the way of crushing - the flakier, the lower resistance. The resistance is also affected by the amount of foreign material, for example a lot of masonry and lightweight concrete decreases the resistance. High strength in the original concrete yields better resistance to wear. If the concrete material is clean, the fines produced are not plastic as in natural aggregates, but contribute to the stiffness increase due to carbonation as mentioned above.

Recycled crushed concrete is manly used as base or sub-base in roads or parking spaces or as fillings in other construction purposes. Test sections with unbound layers of crushed concrete in road base and sub-base show good durability compared to reference sections with unbound rock materials (Ydrevik, 1999; Arm, 2007).

Approximately $60 \%$ of the $\mathrm{CO}_{2}$ emission from cement production stems from the calcinations of limestone. Theoretically, hardened concrete in the long-term will bind the same amount of $\mathrm{CO}_{2}$ in a process called carbonation. When concrete structures are demolished and refined to recovered concrete aggregates the surface area is largely increased and the $\mathrm{CO}_{2}$ uptake rate per is therefore increased in the secondary life. Figures on increased $\mathrm{CO}_{2}$ uptake are still to unsecure to be incorporated in the LCA of concrete aggregates according to Stripple, H. (2010).

\section{Asphalt}

Experiences and requirements on recycling and recovery of aspahlt in roads on a European level is being addressed in the ongoing DirectMat project (DirectMat 2010). Swedish experiences have been summarized in literature reviews that will be published at the DirectMat home page.

There are no national asphalt pavement statistics for Sweden and figures on asphalt production and recycling are being based on expert judgement. The yearly production of hot mix asphalt is about 7-8 $\mathrm{M}$ tons and for cold bituminous mixes 0.5-1 million tons. Every year, about 1-1.5 M tones of reclaimed asphalt (RA) material are produced in Sweden. The Swedish Road Administration which keeps statistics is responsible for about half 
of this. Swedish Road Administration established a goal in 1996 to recycle at least $90 \%$ of all RA in year 2000. This goal was reached already in 1998. Today recycling of RA in bound layers is good economy as a result of rising bitumen prices and RA is often assigned economic values in contracting.

Secondary aggregates in asphalt (e.g. slag) have been used very infrequently and only locally but old Swedish asphalt pavements, from 1940 to 1974 , often contain coal tar. It has been estimated that about $30 \mathrm{M}$ ton of tar asphalt is present in Swedish asphalt pavements and that about $170,000-2,150,000$ tonnes of tar containing recovered asphalt arise every year (Wik et al., 2005).

The main reasons for reclamation of asphalt pavements are:

- Complete removal of pavement or road works such as pipe works which is most frequent in city roads.

- Removal of asphalt layers, i.e. deep milling in wheel paths or removal of inferior materials.

- Planning and levelling before new layers are placed, either to get an even foundation for subsequent layer or to adjust levels for adjacent pavement, curbs, manhole covers etc.

In the process of removal, either planning/milling or in the case of complete removal or road works digging is used. Dug up material is cleaned from non asphalt materials or sources of contamination in a general context. It is recommended that road markings are removed by milling prior to removal of asphalt layers.

Tar asphalt is usually restricted to a single layer in the pavement. Old tar containing layers has over the years been overlaid with new uncontaminated wearing course asphalt. As a result maintenance of wearing course can be performed without the risk of being contaminated with tar asphalt. If it is possible, contaminated asphalt layer should be separated from tar contaminated asphalt by cold milling. In older streets and roads it can be difficult in practice to effectively separate the asphalt, unless control is very accurate, because the layer thickness can vary greatly. At excavation of asphalt, it is generally impossible to separate tar contaminated layers from pure asphalt layers but the amount of unbound material in the masses should be limited. Left-over layers of tar asphalt should be excavated and removed not milled. The material is significantly more granulated when milling instead of excavating, which can complicate the retention of the masses. 
Handling of RA after the reclamation stage is considered as being important. RA should be sorted separate groups according to different quality aspects:

- Surface layers from different pavement types.

- Mixed layers.

- Mixed pavements types.

- Contaminated pavements.

Milled pavements can exceptionally be reused without further treatment but normally crushing and sieving is performed to ensure quality and homogenisation requirements. It is recommended that a delicate crushing is performed and that oversized aggregates are crushed separately (Swedish Association of Local Authorities and Regions, 2004).

Recycling of asphalt in new pavements can be performed in-plant, see Table 33, or in-situ, see Table 34.

Table 33: In-plant asphalt recycling methods ${ }^{1}$

\begin{tabular}{llll} 
Method & Application & Added binder & Normal amount of reclaimed asphalt \\
$\begin{array}{l}\text { Hot } \\
\text { recycling }\end{array}$ & $\begin{array}{l}\text { For wear-, bind- and base layer } \\
\text { for all traffic volumes and road } \\
\text { categories }\end{array}$ & Bitumen & $\begin{array}{l}\text { Between } 5 \text { and } 30 \% \text { depending on } \\
\text { reclaimed asphalt, the process, kind of } \\
\text { plant and kind of layer }\end{array}$ \\
$\begin{array}{l}\text { Warm } \\
\text { recycling }\end{array}$ & $\begin{array}{l}\text { For wear- and base layer, } \\
\text { mostly for lower volumes of } \\
\text { traffic }\end{array}$ & $\begin{array}{l}\text { Soft bitumen or } \\
\text { foamed bitumen }\end{array}$ & More than $80 \%$ \\
$\begin{array}{l}\text { Cold } \\
\text { recycling }\end{array}$ & $\begin{array}{l}\text { For wear- and base layer, } \\
\text { mostly for lower volumes of } \\
\text { traffic }\end{array}$ & $\begin{array}{l}\text { Bitumen emulsion, } \\
\text { soft bitumen or } \\
\text { foamed bitumen }\end{array}$ & More than $80 \%$ \\
\hline
\end{tabular}

Note: $\quad{ }^{1}$ Guidance schemes on how to perform simplified environmental and cost assessment in a life cycle perspective are available (Swedish Road Administration 2004b). Input (generic) data are not supported but should be audited on case by case premises. 
Table 34: Most frequently used techniques for in-situ recycling in Sweden

\begin{tabular}{ll} 
Repaving & $\begin{array}{l}\text { Warming up, scarifying and levelling of the existing asphalt and applying new asphalt } \\
\text { mix layer }\end{array}$ \\
Hot remixing & $\begin{array}{l}\text { Warming up and scarifying of the existing asphalt and mixing with new asphalt mix. New } \\
\text { binder and softening agent can be added }\end{array}$ \\
Remixing Plus & A combination of remixing and repaving \\
Warm remixing & $\begin{array}{l}\text { The pavement is moderately heated with a heater and then a machine is milling and add- } \\
\text { ing new mix or soft bitumen before laying }\end{array}$ \\
Stabilisation & $\begin{array}{l}\text { Old asphalt bound layers are milled and incorporated in the lower base and subbase layers } \\
\text { and new binder is added in the form of bitumen emulsion or foamed bitumen. Down to } \\
20 \mathrm{~cm} \text { depth }\end{array}$ \\
Cold Remixing & $\begin{array}{l}\text { Asphalt layers are milled and mixed with bitumen emulsion, aggregate or mixture before } \\
\text { laying. Down to } 10 \mathrm{~cm} \text { depth }\end{array}$ \\
\hline
\end{tabular}

Crushed asphalt granulate can be suitable in unbound base and sub-base layers, especially when the aggregate comprises a high portion of rock material. Practical experience shows that this type of material can obtain a load bearing capacity that is as good as or even better than that of crushed rock in a base or sub-base layer. Stability can be problematic if bitumen content is too high or if the material is poorly compacted. It is not recommended to use asphalt granulates were high static loads are expected, because it increases the risk for deformation. The use of asphalt granulates can reduce the amount of dust emitted from the road surface of gravel roads and at construction sites. Approximately $40 \%$ of RA generated within Swedish Road Administration is reused in unbound applications. In the Malmö region the use in unbound applications to improve gravel surfaces has been widespread (e.g. farmers) as a result of endorsement of the technique from Swedish Road Administration (Tell, R., 2010). 
Table 35: Techniques used for recycling in unbound applications

$\begin{array}{ll}\text { Technique } & \text { Description } \\ \text { Deep milling } & \begin{array}{l}\text { Asphalt layers are milled down to } 50 \mathrm{~cm} \text { into the unbound layers and no extra } \\ \text { binder is added }\end{array} \\ \text { Low traffic gravel roads } \quad \begin{array}{l}\text { Granulates of sieve fraction 0-11 or 0-18 mm are used in a layer thickness of } \\ \text { about } 50 \mathrm{~mm} \text {. To obtain the best result, the granulates are mixed with ordinary } \\ \text { gravel for surfacing of gravel roads. The mix is then levelled with a road grader. } \\ \text { This procedure can be repeated when the road surface is rutted after it has been } \\ \text { subject to traffic for some time. One problem that can occur is that the asphalt } \\ \text { granulates lump together and create a brittle layer. This layer is sensitive to } \\ \text { cracks and potholes can develop } \\ \text { Granulates of sieve fraction 0-18 mm. Compaction can be done with the wheels of a } \\ \text { truck. Asphalt granulate has sticky behaviour and will therefore decrease the risk for } \\ \text { erosion when the ditch and road shoulders are subject to large water flows. A draw- } \\ \text { back is that the roadside has similar colour to the road }\end{array} \\ \begin{array}{l}\text { Used for temporary repair of potholes, water damages and other damages on the } \\ \text { asphalt surface. The advantage compared to gravel is that it sticks better on place }\end{array} \\ \begin{array}{l}\text { Temporary repair } \\ \text { Used on surface layer for heavy traffic at construction sites. The advantage is that it } \\ \text { emits little dust. It gives not a smooth surface but can work temporary. After use the } \\ \text { material can be removed and reused elsewhere. }\end{array}\end{array}$

Dismantled and excavated asphalt pavements containing tar asphalt may be classified as hazardous waste according to the Swedish waste regulation. The reason is that tar containing waste is classified as hazardous waste according to the current European Waste Directive. However, the Swedish Road Administration does not regard tar containing asphalt that is recycled on-site (in the same road) as waste.

Recommendations for the dismantling of old asphalt layers:

- Determine whether the asphalt pavement contains tar. Historic registers on the construction of asphalt pavements can been used to identify the roads and pavements that are contaminated with tar. Sampling and mapping is an alternative when registers are lacking e.g. in cities.

- Consult responsible environmental authorities if tar containing materials will be reused.

- Try to keep contaminated materials separated from pure bituminous mixtures.

- Inform the staff about the tar content in the asphalt material. 
Life cycle assessments of tar contaminated RA indicate that recycling in new pavements in favourable (Andersson-Sköld et al. 2007). According to Swedish Road Administration (2003), excavated asphalt pavements containing less than $70 \mathrm{mg} / \mathrm{kg}$ of "16-PAH" are regarded free from tar and can be reused without restrictions. Asphalt pavements containing tar, i.e. containing at least $70 \mathrm{mg} / \mathrm{kg} 16-\mathrm{PAH}$, must be handled as follows:

For all tar containing asphalt materials:

- The asphalt material is primarily reused within the same site.

- The asphalt material is used as bound or unbound road base.

- Cold or semi-hot recovery method used.

- Base layer is covered with dense wearing course.

- The asphalt material can be used in such sound barriers if they are covered by plastic sheet or other water diversion protection layer.

- The asphalt material must be above the groundwater table.

- Staff dealing with the material should be informed.

At concentrations between 300 and 1,000 mg/kg of 16-PAH:

- Intermediate storage is done only if the asphalt material can not be used directly. The storage should be limited in time.

- Stored material has to be covered to prevent leaching.

- Storage of uncovered material should be performed at close support and combined with device for disposing of leachate water.

- Storage should not be made at sensitive sites, such as water protection area.

- Reuse is not made within sensitive land areas.

At concentrations above $1,000 \mathrm{mg} / \mathrm{kg}$ of $16-\mathrm{PAH}$ asphalt might be classified as hazardous waste and a special investigation has to be made on how to handle the material in the best environmental and technical way. Swedish EPA has proposed a guideline value of $300 \mathrm{mg} / \mathrm{kg}$ of PAH 16 for classification of tar asphalt as hazardous waste. 


\section{Anti-skid gravel and sand}

Each year, nearly 750,000 tonnes of anti-skid material is swept up from Swedish roads, streets and squares. The material can often be recovered, but the solutions and techniques vary among municipalities. The Swedish Association of Local Authorities and Regions has published a guide that presents solutions meeting high standards for health and environment (2008). Gathered anti-skid material is classified as waste but not hazardous waste. Possible recovery actions are: recycling as anti-skid material after soil washing, recovery as fill material or in asphalt production. Several examples of how Swedish municipalities handle the material are also provided.

\section{Soils and Sediments}

In general, Swedish Road and Rail Administration promotes recycling as much as possible in construction and demolition projects. In each project, a programme should be drawn up in order to obtain a management plan that is economically and environmentally successful. In the first place, excavated soils of sufficient quality are recovered in each project. Primary uses are for embankment filling. They can also be used for construction of road side area to improve the road and rail environment e.g. use for filling around culverts and crossings, to cover the slopes of hills or large rocks for facilitated vegetation mowing or in order to stabilize steep road side area to improve road safety. Many low quality materials, e.g. vegetation layers or soil containing silt and clay, can be used for construction of noise barriers.

Swedish Road and Rail Administration has written an administrative guides in cooperation with legal expertise (Swedish Road Administration, 200ba, Swedish Rail Administration, 2002) which describes how to categorize excavated soil and when it should be regarded as waste. Swedish Road Administration has also developed a guide for soil from road ditches including sampling and testing and also environmental criteria for different uses (Swedish Road Administration, 2007c). Soils from roads with high traffic volume ( $>10,000$ vehicles/day) must be sampled and analysed before use in the "road area". However, the place for use can require certain precautions, e.g. for use in water protection area, national park and cultural reserves. Swedish Road Administration has published a maintenance guideline for open pond runoff treatment facilities (Swedish Road Administration, 2008). It includes advice and techniques for sediment sampling, analysis, removal, disposal or reuse at the site. Preferably the sediment should be reused within the treatment facility area. If this is not possible, it should be treated at an approved treatment plant or land- 
filled. Results from previous studies of sediment composition give information on how the content of pollutants and the leaching characteristics of sediment may vary.

Naturally occurring sulphidic soil and rock materials in Sweden can have elevated levels of metals and pose a significant environmental risk when becoming extremely acidic (i.e. $\mathrm{pH}<4$ ) as a result of oxidation of sulphide minerals contained. Large amounts of these materials can be encountered in infrastructure projects but are not considered to be waste if they are suitable to be recovered as fill or aggregates (Swedish Road Administration, 2007b, Swedish Road Administration, 2007d, Arm, M., 2010). Guidelines on the management of sulphidic soils have been published (Swedish Road Administration, 2007c) and guidelines on management of sulphidic rock are in preparation (Arm, M., 2010).

Even though the tools to calculate guideline values are essentially the same Swedish Road and Rail Administration Guideline values for recovery of soil generally significantly exceeds the guideline values published by Swedish EPA, see Table 36. The Swedish Road and Rail Administrations have been replaced by the Swedish Transport Administration. The Swedish Transport Administration began operations on 1 April 2010 and includes activities and operations that before 1 April 2010 were undertaken by the the Swedish Rail Administration and the Swedish Road Administration. The joining of rail and road administrations and the discrepancies between "rail", "road" and Swedish EPA guideline values has initiated work on updating guideline values for the transport sector which is expected to be completed 2011 (Löwegren, N., 2010).

Table 36: Examples on environmental criteria for reuse of soil from roads and railways

\begin{tabular}{|c|c|c|c|c|c|c|c|}
\hline Element (mg/kg TS) & As & $\mathrm{Pb}$ & $\mathrm{Cu}$ & $\mathrm{Zn}$ & $\mathrm{Cd}$ & $\begin{array}{l}\text { Canc } \\
\text { PAH }\end{array}$ & $\begin{array}{r}\text { Other } \\
\text { PAH }\end{array}$ \\
\hline $\begin{array}{l}\text { Swedish Road Administration, (2007b) } \\
\text { Criteria for use in "non sensitive areas" }\end{array}$ & - & 250 & 200 & 700 & 12 & 2 & 15 \\
\hline $\begin{array}{l}\text { Swedish Rail Administration, (2002) } \\
\text { Criteria for use in "non sensitive areas" }\end{array}$ & 15 & 150 & 200 & 700 & 2 & 2 & 40 \\
\hline $\begin{array}{l}\text { Swedish EPA (2010c) } \\
\text { Criteria for free use (mg/kg TS) }\end{array}$ & 10 & 20 & 40 & 120 & 0,2 & 0,5 & $0,6-2$ \\
\hline $\begin{array}{l}\text { Swedish EPA (2010c) } \\
\text { Criteria for use on top of landfills (mg/kg TS) }\end{array}$ & 10 & 200 & 80 & 250 & 1,5 & $3-10$ & 2,5 \\
\hline
\end{tabular}




\title{
Appendix 6: Leaching as a function of $\mathrm{L} / \mathrm{S}$ and $\mathrm{pH}$
}

\author{
Leaching as a function of $\mathrm{L} / \mathrm{S}$ and $\mathrm{pH}$
}

\section{Leaching as a function of $L / S$}

The liquid to solid ratio (L/S) describes the ratio between the amount of liquid (in a leaching test normally demineralised water) measured in litres and the amount of solid (e.g. aggregate measured as dry mass) measured in $\mathrm{kg}$, which are brought into contact with each other in a leaching test. In a batch leaching test $\mathrm{L} / \mathrm{S}$ is based on the total amount of water added to the solid, whereas $\mathrm{L} / \mathrm{S}$ in a column or percolation leaching test is based on the amount of eluate collected at any time during the test. For leaching systems under equilibrium or near-equilibrium conditions, the expression of results of leaching tests as concentrations of a substance in the eluate or as accumulated leached amounts of a substance as a function of $\mathrm{L} / \mathrm{S}$ is very convenient and allows the comparison of results from different test methods, in particular percolation tests and batch leaching tests. This is illustrated in Figure 10 which shows accumulated leached amounts of Mo from an aggregate (bottom ash from incineration of hazardous waste) as function of L/S from a percolation test (CEN/TS 14405) and a two-step batch leaching test (EN 12457-3). The figure also shows the total content of Mo in the aggregate. It can be seen that the batch test results represent two points on the leaching curve described by the percolation test results. Also note the substantial difference between the total content and the leachable amounts of Mo. 
Figure 10: Results of percolation and batch leaching tests on an aggregate shown as a function of L/S

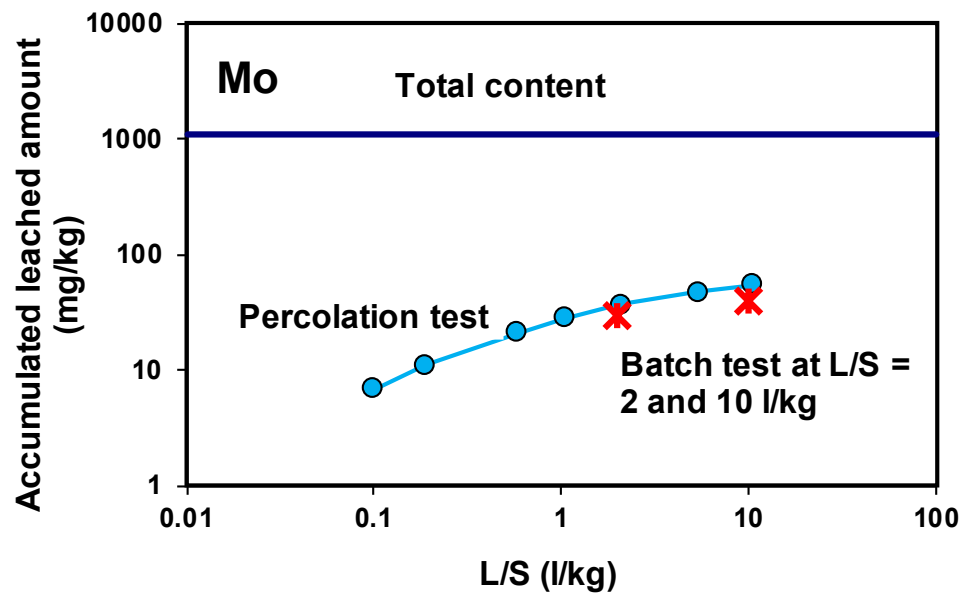

In some cases when sufficient information is available, results from observation of full scale applications of aggregates in the field may also be described as a function of $\mathrm{L} / \mathrm{S}$ and compared to results of leaching tests performed on the same material in the laboratory. It is therefore sometimes possible - with considerable caution - to predict certain aspects of the leaching behaviour of an aggregate under field conditions on the basis of laboratory leaching tests, using relatively simple modelling tools, although supplementary hydrogeochemical equilibrium modelling is often required to account for longer term effects. It is, of course, important to validate such prediction methods to the extent possible by appropriate comparisons between lab and field results. Most laboratory leaching tests on granular materials performed under equilibrium-like conditions are accelerated in time compared to the actual duration of leaching under field conditions. 
Under certain conditions, and when the physical layout and hydraulic/water balance situation for a full scale application is known the $\mathrm{L} / \mathrm{S}$ scale may be converted to a time scale for that particular utilisation scenario. This can be done by means of the following equation (Hjelmar, 1990):

$\mathrm{T}=(\mathrm{L} / \mathrm{S}) \times \mathrm{d} \times \mathrm{H} / \mathrm{I}$

Where:

- $\mathrm{T}$ is the time since the production leachate from the application started (years).

- $\quad \mathrm{L}$ is the total volume of leachate produced at time $\mathrm{T}\left(\mathrm{m}^{3}\right)$.

- $\mathrm{S}$ is the total mass of aggregate used in the application (tonnes, dry mass).

- $\mathrm{d}$ is the average dry bulk density of the aggregate in the application (tonnes $/ \mathrm{m}^{3}$ ).

- $\mathrm{H}$ is the average height of the application (m).

- I is the annual net rate of infiltration of precipitation $\left(\mathrm{m}^{3} / \mathrm{m}^{2}\right)$.

It is assumed that percolation of the infiltrated precipitation is the sole source of leachate in the application.

The relationship between $\mathrm{L} / \mathrm{S}$ and time is illustrated in Figure 11 for an unbound application of an aggregate with a bulk density of 1.5 tonnes $/ \mathrm{m}^{3}$, heights of $0.5 \mathrm{~m}$ and $5 \mathrm{~m}$, and annual rates of infiltration of precipitation of $50 \mathrm{~mm}$ and $200 \mathrm{~mm}$, respectively.

Figure 11: Illustration of the relationship between $\mathrm{L} / \mathrm{S}$ and time, using equation (A1.1)

\begin{tabular}{|c|c|c|c|c|c|c|c|}
\hline $\begin{array}{c}\text { Height } \\
\text { H } \\
\text { m } \\
\end{array}$ & $\begin{array}{c}\text { Infiltration } \\
\text { I } \\
\mathrm{mm} / \text { year }\end{array}$ & $\begin{array}{l}\text { L/S } \\
\mathrm{I} / \mathrm{kg}\end{array}$ & $\begin{array}{c}\text { Time } \\
\mathbf{T} \\
\text { Years }\end{array}$ & $\begin{array}{c}\text { Height } \\
\text { H } \\
m \\
\end{array}$ & $\begin{array}{c}\text { Infiltration } \\
\text { I } \\
\mathrm{mm} / \text { year }\end{array}$ & $\begin{array}{l}\mathrm{L} / \mathrm{S} \\
\mathrm{I} / \mathrm{kg} \\
\end{array}$ & $\begin{array}{c}\text { Time } \\
\mathbf{T} \\
\text { Years }\end{array}$ \\
\hline 0.5 & 50 & 1 & 15 & 0.5 & 200 & 1 & 3.8 \\
\hline 0.5 & 50 & 2 & 30 & 0.5 & 200 & 2 & 7.5 \\
\hline 0.5 & 50 & 5 & 75 & 0.5 & 200 & 5 & 19 \\
\hline 0.5 & 50 & 10 & 150 & 0.5 & 200 & 10 & 38 \\
\hline 5 & 50 & 1 & 150 & 5 & 200 & 1 & 38 \\
\hline 5 & 50 & 2 & 300 & 5 & 200 & 2 & 75 \\
\hline 5 & 50 & 5 & 750 & 5 & 200 & 5 & 188 \\
\hline 5 & 50 & 10 & 1500 & 5 & 200 & 10 & 375 \\
\hline
\end{tabular}


When using leaching data as input to transport and behaviour models, it is often convenient to be able to quantify the leaching process in terms of simple mathematical formulas. The leaching of several (but not all) inorganic contaminants in an equilibrium controlled system, including a percolation test, may be described as resulting in an initial or early peak concentration of the substance in the leachate followed by an exponential decrease of the concentration with time (or L/S). If it is assumed that a continuously stirred tank reactor (CSTR) model (see van der Sloot et al., 2003) can be used to interpret the results of a column leaching test on the granular waste material, the leaching of several components may be expressed by a simple decay function:

$\mathrm{C}=\mathrm{C}_{0} * \mathrm{e}^{-(\mathrm{L} / \mathrm{S}) \mathrm{k}}$

where $\mathrm{C}$ is the concentration of the contaminant in the leachate as a function of $\mathrm{L} / \mathrm{S}(\mathrm{mg} / \mathrm{l})$, the constant $\mathrm{C}_{0}$ is the initial peak concentration of the contaminant in the leachate $(\mathrm{mg} / \mathrm{l}), \mathrm{L} / \mathrm{S}$ is the liquid to solid ratio corresponding to the concentration $\mathrm{C}(\mathrm{l} / \mathrm{kg})$ and where $\kappa$ is a kinetic constant describing the rate of decrease of the concentration as a function of $\mathrm{L} / \mathrm{S}$ for a given material and a given substance $(\mathrm{kg} / \mathrm{l})$. $\kappa$ values may be estimated from column, lysimeter or serial batch leaching data (see van der Sloot et al., 2003).

By integrating the above expression, the amount of the substance, E (in $\mathrm{mg} / \mathrm{kg}$ ), released over the period of time it takes for $\mathrm{L} / \mathrm{S}$ to increase from $0 \mathrm{l} / \mathrm{kg}$ to the value corresponding to $\mathrm{C}$, can be calculated:

$\mathrm{E}=\left(\mathrm{C}_{0} / \kappa\right)\left(1-\mathrm{e}^{-(\mathrm{L} / \mathrm{S})} \mathrm{k}\right)$

Even if it is not entirely true, it is assumed that $\kappa$ is independent of the material leached, but specific for each substance. The larger $\kappa$ is, the faster will the concentration in the eluate decrease as a function of $\mathrm{L} / \mathrm{S}$. This is illustrated in Figure 12 which shows $\mathrm{C} / \mathrm{C}_{0}$ as a function of $\mathrm{L} / \mathrm{S}$ for different values of $\kappa$. 
Figure 12: $C / C_{0}$ as a function of $L / S$ for different values of $\kappa$

For substances for which the leaching from an aggregate progresses as described by equation (A6.2), the equation can be used to "translate" a leaching result (or a limit value associated with a percolation or batch leaching test) from one $\mathrm{L} / \mathrm{S}$ value to another. If $\mathrm{E} 1$ is the amount leached of the substance at $(\mathrm{L} / \mathrm{S})_{1}$, the amount $\mathrm{E} 2$ leached at $(\mathrm{L} / \mathrm{S})_{2}$ can be calculated as follows:

$\mathrm{E} 2=\mathrm{E} 1 *\left(1-\mathrm{e}^{-(\mathrm{L} / \mathrm{S}) 2 \kappa}\right) /\left(1-\mathrm{e}^{-(\mathrm{L} / \mathrm{S}) 1 \kappa}\right)$

This method was used when setting equal limit values ( $=$ values on the same leaching curve) at $\mathrm{L} / \mathrm{S}=2 \mathrm{l} / \mathrm{kg}$ and $\mathrm{L} / \mathrm{S}=10 \mathrm{l} / \mathrm{kg}$ for acceptance of waste for landfilling in Council Decision 2003/33/EC. The kappa values used were taken mostly from Aalbers et al. (1998). They are shown in Table 37. 
Table 37: List of the $\kappa$ values for inorganic components and phenol and DOC used in the TAC calculations

\begin{tabular}{|c|c|c|c|}
\hline Substance & $\begin{array}{l}\text { Average values and } 95 \% \\
\text { confidence intervals for } \mathrm{\kappa}(\mathrm{kg} / \mathrm{l})\end{array}$ & $\begin{array}{l}\text { Number of } \\
\text { determinations }\end{array}$ & Data source \\
\hline As & $0.03 \pm 0.05$ & 44 & Albers et al. (1996) \\
\hline $\mathrm{Ba}$ & $0.15 \pm 0.04$ & 55 & Albers et al. (1996) \\
\hline $\mathrm{Cd}$ & $0.50 \pm 0.10$ & 37 & Albers et al. (1996) \\
\hline $\mathrm{Cr}$ & $0.18 \pm 0.03$ & 82 & Albers et al. (1996) \\
\hline $\mathrm{Cu}$ & $0.28 \pm 0.03$ & 90 & Albers et al. (1996) \\
\hline $\mathrm{Hg}$ & $0.05 \pm 0.03$ & 5 & Albers et al. (1996) \\
\hline Mo & $0.35 \pm 0.04$ & 76 & Albers et al. (1996) \\
\hline $\mathrm{Ni}$ & $0.29 \pm 0.05$ & 37 & Albers et al. (1996) \\
\hline $\mathrm{Pb}$ & $0.27 \pm 0.06$ & 52 & Albers et al. (1996) \\
\hline $\mathrm{Sb}$ & $0.11 \pm 0.07$ & 33 & Albers et al. (1996) \\
\hline $\mathrm{Se}$ & $0.38 \pm 0.18$ & 10 & Albers et al. (1996) \\
\hline $\mathrm{Zn}$ & $0.28 \pm 0.05$ & 41 & Albers et al. (1996) \\
\hline Chloride & $0.57 \pm 0.07$ & 45 & Albers et al. (1996) \\
\hline Fluoride & $0.22 \pm 0.14$ & 6 & Albers et al. (1996) \\
\hline Sulphate & $0.33 \pm 0.05$ & 49 & Albers et al. (1996) \\
\hline Phenol & 0.3 & Estimate & ECN (DHI \&ECN, 2003) \\
\hline $\mathrm{DOC}$ & 0.17 & Estimate & ECN (DHI \&ECN, 2003) \\
\hline
\end{tabular}

\section{Porewater concentrations}

It is sometimes useful or necessary to be able to estimate the porewater concentrations for an aggregate from the results of a leaching test. In principle, the first fraction of eluate from a well equilibrated column leaching test should have a composition similar to that of the porewater under saturated conditions. If the eluate or leachate composition for an aggregate is described as a function of $\mathrm{L} / \mathrm{S}$, either in terms of test results or as an exponentially decreasing source term based on kappa $(\kappa)$ values - assuming a simple CSTR model of the leaching process as described above - then the porewater concentration may be found by interpolation of the results to the $\mathrm{L} / \mathrm{S}$ value which represents the pore volume of the aggregate in a given application. The relationship between pore volume and L/S will be:

$(\mathrm{L} / \mathrm{S})_{\mathrm{PV}}=\mathrm{n} / \mathrm{d}_{\mathrm{DB}}$

where $(\mathrm{L} / \mathrm{S})_{\mathrm{PV}}$ is the $\mathrm{L} / \mathrm{S}$ value corresponding to the pore volume $\mathrm{n}$, and $d_{D B}$ is the dry bulk density of the aggregate in the application in question. The concentration at $(\mathrm{L} / \mathrm{S})_{\mathrm{PV}}$ may then be estimated from the leaching curve for a column leaching test. For an aggregate with a dry bulk density of $2 \mathrm{~kg} / \mathrm{l}$ and pore volume of $40 \%$, the pore volume would correspond to $\mathrm{L} / \mathrm{S}=0.20 \mathrm{l} / \mathrm{kg}$. 
If the source term is described as a function of $\kappa$, and only batch test data are available, then the porewater concentration, $\mathrm{C}_{\mathrm{PW}}$, may be described as:

$$
\begin{aligned}
& C_{\mathrm{PW}}=\mathrm{C}_{\mathrm{X}} \cdot\left(\exp \left(-(\mathrm{L} / \mathrm{S})_{\mathrm{PV}} \cdot \kappa\right) /(\exp (-\mathrm{X} \cdot \kappa)),\right. \text { or } \\
& \mathrm{C}_{\mathrm{PW}}=\left(\mathrm{M}_{\mathrm{X}} / \mathrm{X}\right) \cdot\left(\exp \left(-(\mathrm{L} / \mathrm{S})_{\mathrm{PV}} \cdot \kappa\right) /(\exp (-\mathrm{X} \cdot \kappa))\right.
\end{aligned}
$$

where $C_{X}$ is the concentration of a given substance in the eluate from a single batch leaching test (or the first fraction of eluate from a column leaching test) performed at $\mathrm{L} / \mathrm{S}=\mathrm{X}$, and $\mathrm{M}_{\mathrm{X}}$ is the amount of that substance leached at $\mathrm{L} / \mathrm{S}=\mathrm{X}$.

The closer $\mathrm{L} / \mathrm{S}$ of the leaching test is to $(\mathrm{L} / \mathrm{S})_{\mathrm{PV}}$, the more accurate is the estimation likely to be. This means that in general, leaching data from a batch test performed at $\mathrm{L} / \mathrm{S}=2 \mathrm{l} / \mathrm{kg}$ is likely to provide better porewater estimations than data from a batch test performed at $\mathrm{L} / \mathrm{S}=10 \mathrm{l} / \mathrm{kg}$.

Similarly, $\kappa$ values based on the initial part of the leaching curve, i.e. determined at low $\mathrm{L} / \mathrm{S}$ values are likely to provide better porewater concentration estimates than $\kappa$ values based on the entire $\mathrm{L} / \mathrm{S}$ range from 0 to $10 \mathrm{l} / \mathrm{kg}$ or on the high $\mathrm{L} / \mathrm{S}$ part of the leaching curve. The best option will be to use the first few fractions from the column leaching test $(\mathrm{L} / \mathrm{S}=$ $0-0.5 \mathrm{l} / \mathrm{kg}$ ).

When using the CSTR model to describe the source term or to estimate the porewater concentrations for steel slag, the estimate of the $\kappa$ values used could be improved by determining them specifically for aggregates under consideration. The general values determined by Aalbers et al. (1996) - see Table 37 - and used in the setting of the EU waste acceptance criteria for landfills (Hjelmar et al., 2005) may not provide the optimal description of the source term for all aggregates.

\section{Leaching as a function of $\mathrm{pH}$}

It is generally accepted that $\mathrm{pH}$ is the major chemical variable that controls the leachability of both major and minor substances from most aggregates. Relatively small changes in $\mathrm{pH}$ can either increase or decrease leached concentrations by several orders of magnitude for many substances, among which both (cationic) metals and oxyanions. The influence of $\mathrm{pH}$ is based on the strong dependency on this parameter of the solubility of important minerals that may occur in aggregates, such as oxides, hydroxides and carbonates. In addition to these mineral precipitation/dissolution processes, both cationic and anionic constituents are bound to the solid residues by adsorption/desorption on reactive mineral 
and/or organic surfaces with a pH-dependent charge. Both types of processes (solubility and sorption) result in general terms in the same $\mathrm{pH}-$ dependency of release process in that the leaching of cationic constituents increases towards low $\mathrm{pH}$ and the leaching of anionic constituents increases towards high $\mathrm{pH}$. This general leaching behaviour can be further modified by the effect of other chemical parameters, as discussed below. For alkaline aggregates, changes in $\mathrm{pH}$ may for example occur as a result of exposure to carbon dioxide $\left(\mathrm{CO}_{2}\right)$ in atmospheric air as a result of maturation prior to use or as part of the ageing processes in the field. For this reason the leaching properties of a freshly produced alkaline aggregate may be completely different from those of the same material in a carbonated/aged state. 


\title{
Appendix 7: Description of leaching tests
}

\author{
Leaching protocols
}

\section{General}

Leaching tests are basically carried out for the purpose of providing answers to questions, such as "What is the initial concentration of the eluate/leachate from an aggregate being percolated by infiltrating rainwater?" or "What is the total leachable amount of various substances from an aggregate?" or "How does the leachability of various substances vary with $\mathrm{pH}$ ?" or "Does this aggregate comply with the regulatory limit values for this or that purpose?"- and many others. Several questions are relevant for an assessment of the compliance of an aggregate with possible leaching requirements for the achievement of EoW status. Clearly, one single test cannot provide all the necessary answers, but a few, carefully selected leaching tests will be sufficient. The tests should be selected on the basis of the nature of the questions to be answered and the leaching mechanisms involved.

Historically, numerous leaching tests have been developed within different fields with slightly different purposed and slightly different test conditions for different materials. There is, however, a strong movement towards harmonisation of leaching standards and test methods. Most materials can be assessed by means of a little handful of test methods. Table 38 presents this limited number of test types and the most important CEN and ISO methods and standards relevant to testing of aggregates.

Within the European Standardisation Organisation, CEN, test methods have different status according to their stage of development. Fully developed European test methods are called standards and labelled EN XXXXX if the method is validated, i.e. its robustness (sensitivity to changes in test conditions) and performance (repeatability and reproducibility) have been determined. If a method is developed but not yet validated, it is called a CEN technical specification, CEN/TS XXXXX. A draft standard or technical specification which has been submitted to voting within CEN but 
has not yet been fully processed in the system is often labelled prEN or prCEN/TS (preliminary standards or technical specifications).

It is widely accepted that the testing tools for waste materials and products within the different legislative regimes for different evaluations - landfilling in accordance with the Landfill Directive/Council Decision, use and recycling of waste materials in accordance with national waste regulations or the CPD/CPR and potential future regulation on EoW criteria - should be the same to the extent possible to avoid double testing of the same material or product falling under different regulatory regimes.

Table 38: Relevant CEN and ISO leaching standards and standards under development

\begin{tabular}{llll} 
Test type & Soil, sediments, compost and sludge & Waste & Construction products \\
pH dependence test & ISO/TS 21268-4 & CEN/TS 14429 & CEN/TS 14429** \\
& & CEN/TS 14997 & CEN/TS 14997** \\
Percolation test & ISO/TS 21268-3 & CEN/TS 14405 & CEN/TC351/TS-3 \\
Batch test & ISO/TS 21268-1 and 2 & EN 12457-1 to 3 & EN 12457** \\
Tank test & & CEN/TS 15863 & CEN/TC351/TS-2 \\
& & CEN/TS 15864 & \\
\hline
\end{tabular}

Note: $\quad * *$ Has been applied but is not (yet) a method approved by CEN/TC 351.

In the following, the proposed "tool kit" for EoW assessment of the leaching properties of aggregates, i.e. the most important of the leaching protocols listed in Table 38, are presented in more detail.

The proposed tool kit for assessment of the leaching properties of aggregates contains the following tests:

- $\mathrm{pH}$ dependence tests (CEN/TS 14429 and CEN/TS 14997).

- Percolation test (CEN/TS 14405 and CEN/TC 351/TS-3).

- Batch leaching test (EN 12457-1, 2 or 3), to be included when used for compliance or FPC.

The above tests are all performed on granular or size reduced material in accordance with the discussion of the most critical EoW scenarios to be assessed. Even though the testing of intact bound materials cannot be recommended in relation to the EoW use and EoL scenarios with or without conditions or restrictions, two methods for determination of surface/diffusion related release will also be briefly described to complete the toolbox: 
- Tank leaching test for monolithic materials (prCEN/TS 15863 and DSLT CEN/TC 351/TS-2).

- Tank leaching test for compacted granular materials (option in DSLT, CEN/TC 351/TS-2).

As pointed out, the tank leaching tests are not part of the proposed testing programme in relation to assessment of EoW criteria for aggregates.

\section{pH dependence leaching tests}

The $\mathrm{pH}$ dependence tests (CEN/TS 14429 and CEN/TS 14997) are used to characterise the $\mathrm{pH}$ dependent leaching behaviour of granular materials and size reduced stabilised/bound materials. Both are size reduced (to $<1 \mathrm{~mm}$ ) prior to testing to minimise diffusion resistance to release and formation of equilibrium. In short, this leaching test involves leaching the size reduced material at (typically) eight $\mathrm{pH}$ values ranging from $\mathrm{pH} 4$ to 12 (the range can be expanded if necessary), each at a liquid to solid ratio (L/S) of $10 \mathrm{l} / \mathrm{kg}$. Nitric acid and sodium hydroxide are used to adjust the $\mathrm{pH}$ to the desired value. In CEN/TS 14429 the different $\mathrm{pH}$ values are obtained through initial addition of acid or base and subsequent check of $\mathrm{pH}$ and adjustment after 6 hours of equilibration. In CEN/TS 14997 the different $\mathrm{pH}$ values are pre-set and maintained by feedback control and continuous addition of acid or base. After 48 hours, the final $\mathrm{pH}$ and electrical conductivity (EC) are measured, and the eluates are filtered $(0.45 \mu \mathrm{m})$ and analysed chemically. The amount of acid or base added equivalents added at the different $\mathrm{pH}$ values provides a measure of the acid/base neutralisation potential of the material. Results are reported as concentrations or leached amounts as a function of $\mathrm{pH}$. The test is generally applicable to assessment of the release of inorganic substances (and DOC) from largely inorganic or mineral aggregates and products. For organic substances special attention must be given to the type of container used to prevent sorption losses. For highly reactive materials (e.g. materials containing significant amounts of $\mathrm{Ca}(\mathrm{OH})_{2}$ and $\mathrm{CaO}$ ) the acid addition must proceed slowly to prevent too strong reactions to the base/acid addition. 


\section{Percolation tests}

The percolation or column leaching test on granular or size reduced material $(95 \%<4 \mathrm{~mm})$ is carried out on waste materials according to CEN/TS 14405 (2004), which is similar to ISO 21268-3 (for soil). In this column test 7 eluate fractions are collected within the range of $\mathrm{L} / \mathrm{S}=0.1-$ $10 \mathrm{l} / \mathrm{kg}(\mathrm{L} / \mathrm{S}=0-0.1,0.1-0.2,0.2-0.5,0.5-1.0,1.0-2.0,2.0-5.0$ and $5.0-$ $10.0 \mathrm{l} / \mathrm{kg}$ ). In some cases, some or all of the eluate fractions are collected together or combined prior to analysis for practical or economic reasons (a deviation from the technical specification). The total test duration is approximately 21 days following a 2 to 3 day pre-equilibration period under saturated conditions. The leachant is demineralised water (DMW). The test material is leached in a column operated in up-flow $(15 \mathrm{~cm} /$ day), typically using a column height of $30 \mathrm{~cm}$ and a diameter of 5 or $10 \mathrm{~cm} . \mathrm{pH}$ is generally controlled by the waste itself in this test. If necessary, the eluates can be collected under nitrogen or argon to prevent e.g. oxidation of reduced species and/or uptake of atmospheric $\mathrm{CO}_{2}$ which could lower the $\mathrm{pH}$ of alkaline eluates. The eluates are filtered through $0.45 \mu \mathrm{m}$ membrane filters and analysed. Results are reported as concentrations or leached amounts as a function of $\mathrm{L} / \mathrm{S}$. It is assumed that the test conditions cause the test to be operated under conditions (particle size and flow velocity) approaching local equilibrium between the matrix of the aggregate and the leachant. ISO $21268-3$ for soil uses a $0.001 \mathrm{M} \mathrm{CaCl}_{2}$ solution instead of demineralised water, and it can be applied to the leaching both of inorganic substances and non-volatile organic substances when proper precautions are taken. The experience with leaching of organic substances is, however, very limited. The harmonised percolation test CEN/TC351/TS-3: "Generic horizontal up-flow percolation test for determination of the release of substances from granular construction products" is based on and very similar to the two other percolation tests. This test is currently undergoing robustness validation to assess the influence of particle size distribution, flow velocity, temperature and pre-equilibration on the test results and adjust the test description accordingly (CEN, 2011). The validation will be finalised by the fall of 2012 . 


\section{Batch leaching tests}

The batch leaching test on granular or size reduced material $(95 \%<$ $4 \mathrm{~mm}$ ) should be carried out according to EN 12457-1 (single batch test at $\mathrm{L} / \mathrm{S}=2 \mathrm{l} / \mathrm{kg}$ ), EN $12457-2$ (single batch test at $\mathrm{L} / \mathrm{S}=10 \mathrm{l} / \mathrm{kg}$ ) or EN 12457-3 (two stage batch test at $\mathrm{L} / \mathrm{S}=2$ and $8 \mathrm{l} / \mathrm{kg}$ to an accumulated $\mathrm{L} / \mathrm{S}$ of $10 \mathrm{l} / \mathrm{kg}$ ). The granular material is placed in a closed bottle with demineralised water and agitated for 24 hours ( 6 and 18 hours for the two stage test). The eluates are filtered through $0.45 \mu \mathrm{m}$ membrane filters and analysed. Results are reported as concentrations or leached amounts as a function of L/S. The batch tests provide information similar to that obtained from the percolation test but averaged over larger L/S ranges and thus showing much less detail (one point on the leaching curve for the one-stage tests, see e.g. Figure 10 in Appendix 6). Only the two-stage test may provide limited information on the development of the release as a function of L/S (two points on the curve). Some EU Member States apply the test EN 12457-4 which is similar to EN 12457-2, except for the fact that it does not require size reduction of particles up to $10 \mathrm{~mm}$. Since the interpretation of the test results are based on the assumption that near equilibrium conditions are achieved during the test, there is a risk that the leaching in EN 12457-4 will be controlled by diffusion instead of equilibrium (and therefore different) if the amount of fines in the material is small. The EN 12457 tests are applicable mainly measure the release of inorganic substances (and DOC) from predominantly inorganic or mineral aggregates.

\section{Tank leaching test}

The tank leach test is performed on monolithic (or bound) products of regular shape above a minimum size according to the new dynamic monolith leach test prCEN TS 15863: "Characterisation of waste - Leaching behaviour test for basic characterisation - Dynamic Monolithic Leaching Test with periodic leachant renewal, under fixed conditions" currently being developed by CEN/TC 292 WG6. A similar, more generally applicable tank test, CEN/TC351/TS-2, is under development in CEN/TC 351 in relation to the implementation of ER3 in the Construction Products Directive. The specimen (minimum size in any dimension $=4 \mathrm{~cm}$ ) is subjected to leaching in a closed tank. Demineralised water is used as the leaching solution at a liquid-to-product volume ratio $(\mathrm{L} / \mathrm{V})$ of approximately $5 \mathrm{~cm}^{3} / \mathrm{cm}^{2}$ (may be varied, according to the more important liquid-to-surface area ration, L/A). The default value for $L / A$ is $8 \mathrm{~cm}^{3} / \mathrm{cm}^{2}$. 
The leaching solution is renewed after $0.08,1,2.25,8,14,15,28,36$ (optional 64) days. The pH, electrical conductivity (EC) and, optionally, Eh are measured in all eluates before filtration $(0.45 \mu \mathrm{m})$ and chemical analysis. A special variation of the tank leaching test incorporated into CEN/TC351/TS-2 is the compacted granular tank test (based on the Dutch Standard NEN 7347) where the material to be tested is placed in a beaker in the tank with the surface exposed to the water. Results are reported as a flux (e.g. $\mathrm{mg} / \mathrm{m}^{2} /$ day) as a function of time or as leached amounts per unit surface area as a function of time. CEN/TC351/TS-2 is currently undergoing robustness validation to assess the influence of the $\mathrm{L} / \mathrm{A}$ ratio, water renewal time schedule and temperature on the test results for both inorganic and non-volatile organic substances and adjust the test description accordingly (CEN, 2011). The validation will be finalised by the fall of- 2012 . 


\title{
Appendix 8: Description of the methodology used to set EU WAC for landfilling
}

\begin{abstract}
Description of the methodology used to set the leaching criteria for acceptance of waste at landfills for inert waste, landfills for non-hazardous waste accepting stable, non-reactive hazardous waste and landfills for hazardous waste listed in Council Decision 2003/33/EC.
\end{abstract}

Ole Hjelmar, DHI

February 2012

\section{Introduction}

The EU Landfill Directive (Council Directive 1999/31/EC of 26 April 1999 on the landfill of waste) did not include criteria for acceptance of waste at landfills. The development of such criteria was deferred to Annex 2 of the directive which outlines the principles to be followed, but leaves the actual specification of methods, parameters and limit values to the Committee for the Adaptation to Scientific and Technical Progress of EC legislation on Waste (generally referred to as the Technical Adaptation Committee, TAC). A TAC Subcommittee on the Landfill Directive (the "TAC Landfill Group") addresses issues associated with the Landfill Directive. During the period February 2000 to April 2002, the TAC Landfill Group undertook the task of developing the waste acceptance criteria (WAC) for the landfill categories defined by the Landfill Directive. The actual work was carried out by a sub-group of national experts and their consultants (the "Modelling Group") which met 8 times between 15 June 2000 and 12 March 2002. Austria, Belgium, Denmark, France, Germany, The Netherlands, Sweden and United Kingdom participated in all or most of the meetings, whereas Finland, Ireland, Italy and Portugal also attended some meetings. The actual modelling work was carried out by consultants/experts from United Kingdom, France, The Netherlands and Denmark. The 
Modelling Group developed leaching limit values for predominantly inorganic waste to be landfilled at landfills for inert waste, landfills for nonhazardous waste accepting stable, non-reactive hazardous waste, and landfills for hazardous waste. Due to the limited time available for the work, WAC were only developed for granular waste, and the development of WAC for monolithic waste was left to the individual Member States. There was agreement that the WAC should be based on scenario calculations and risk assessments. Only the risk to downstream groundwater quality was taken into consideration, again partly due to time constraints.

The methodology used to develop the acceptance criteria in the Council Decision 2003/33/EC has been described in detail by Hjelmar et al. (2001 and 2005), DHI and ECN (2003) and Hjelmar (2003). When the Modelling Group had finalised its work in 2002, the Dutch representation produced and distributed a CD in which the work of the group was documented by collecting most of the working documents produced during the process (VROM, 2002). This CD should be available to all TAC members and can be obtained upon request.

The purpose of this paper is to provide a brief description and documentation of the methodology that was applied to the development of the leaching WAC that was adopted by the TAC Landfill Group and the EU Council and subsequently listed in Council Decision 2003/33/EC of 19 December 2002 establishing criteria and procedures for the acceptance of waste at landfills pursuant to Article 16 and Annex II to Directive 1999/31/EC in order to facilitate future developments, amendments, and changes to the leaching limit values, including the development of $\mathrm{EU}$ or national criteria for acceptance of monolithic waste for landfilling. Special emphasis is placed on the documentation of the principles applied, the assumptions made and the boundary conditions and constants used.

\section{Overall approach and methodology}

The main aims of the development of the leaching WAC for landfilling was that the resulting WAC on the one hand should ensure that there is a direct relationship between the risk against which the WAC should provide protection (impacts on the groundwater quality) and the result of the test to be performed on the waste, while on the other hand, neither the testing nor interpretation of the results should be too complicated. The first aim has high priority with scientists and researchers whereas the second aim is particularly important to regulators. Reaching a reasonable compro- 
mise between the two goals requires sacrifices from both sides. The simplifications and assumptions made during the development of the leaching WAC should be seen this context.

The methodology and the data described in the following are those used in 2000 to 2002 . While there are no changes in the main principles of the risk assessment (applying the "source - pathway - receptor chain") and in establishing a relationship between the result of a leaching test and the downstream groundwater quality, there have been developments in modelling and new groundwater quality criteria may be available, both of which could possibly lead to adjustments/improvements of some of the leaching limit values or additional limit values if applied today. The data and results shown are based on calculations made by ECN and DHI in 2000 to 2002 (referred to as the "TAC calculations"). Parallel calculations were performed by Golders and BRGM using the same assumptions and boundary conditions.

The approach may best be described in terms of a series of consecutive steps. First a decision is made concerning the primary target or point of compliance (POC), e.g. the quality of groundwater at one or more points downstream of the landfill. Quality criteria are then selected for the groundwater, and the physical characteristics of the landfill and environment scenarios are selected and described. The environment scenario includes the net rate of infiltration and a hydrogeological description of the unsaturated and saturated (aquifer) zones upstream, below and downstream of the landfill. The source of the various contaminants is subsequently described in terms of the flux of contaminants as a function of time (or the liquid to solid ratio, L/S) based on leaching data and the hydraulic scenario defined. The leaching is approximated mathematically as an exponentially decreasing function of $\mathrm{L} / \mathrm{S}$, using a component-specific constant, kappa ( $\kappa)$. Then the migration of the contaminants from the base of the landfill through the unsaturated zone into the groundwater and through the aquifer to the POC is modelled including only reversible, sorption-based contaminant/subsoil interaction processes and using proven and accomplished flow and transport models. Selected $\mathrm{K}_{\mathrm{d}}$-values are used for each contaminant to calculate and incorporate the retardation factors (assuming linear sorption isotherms). Based on these "forward" calculations so-called "attenuation factors" (the ratio between peak concentration as modelled at the groundwater POC and the source peak concentration at the base of the landfill) are determined for each contaminant and each scenario. The principle of the three coupled source and transport models is illustrated in Figure 13. 
Figure 13: Cross-section showing the principle of three coupled source and transport models used for the forward impact calculation at a landfill scenario. GWT = Groundwater table

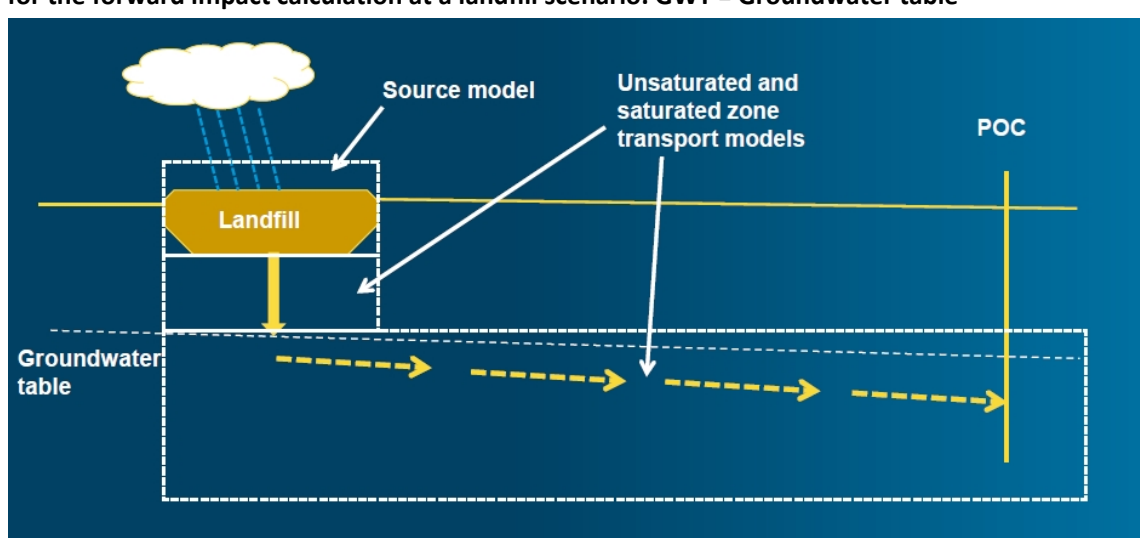

The attenuation factors are then used for a "reverse" calculation of the permissible values of the source term corresponding to the selected groundwater quality criteria for each contaminant at a given scenario and a particular POC. In the TAC calculations the background concentration of the contaminants in the upstream groundwater was not taken into account. The final step consists of transforming the resulting source term criteria to a limit value for a specific test.

It should be noted that the procedure as already mentioned involves simplifications and generalisations of complex and diverse physicalchemical processes. This may be justified by the need to have an operational and relatively simple system, which can be used for the development of general criteria. If needed, it is always possible to apply other or more sophisticated models and to adapt them to other general or sitespecific conditions without changing the principle of the calculations.

\section{Selection of targets for protection and contaminants to be included}

The EU WAC calculations carried out by the Model Group under the Technical Adaptation Sub-committee on landfilling (the TAC calculations) only considered downstream groundwater quality, and the POCs were located $20 \mathrm{~m}$ and $200 \mathrm{~m}$ downstream of the edge of the landfill, respectively. In practice, only the POC located $20 \mathrm{~m}$ downstream of the landfill was used for the setting of criteria.

It would seem appropriate to base the criteria aiming at the protection of groundwater on groundwater quality criteria. The latter are generally 
stricter than drinking water criteria since they take potential effects on the entire ecological system into consideration. Drinking water criteria only consider risks to humans consuming the water and, in addition, make allowance for substantial uptakes of e.g. $\mathrm{Cu}$ and $\mathrm{Zn}$ from water pipes. The problem was that in 2000 - 2002, when the EU WAC were developed, there are international criteria or guidelines (EU/WHO) for drinking water quality, no such international criteria existed for groundwater quality. In fact, national groundwater quality criteria existed only in very few of the Member States. It was therefore proposed to use criteria based on international drinking water criteria and possibly later lower some of those parameters, which were very high compared to normal groundwater values (the value for $\mathrm{Cu}$ was e.g. lowered for this reason). The EU Drinking Water Directive (CEC, 1998) and WHO drinking water criteria (WHO, 1996) in combination provided limit values for the following components in drinking water: As, $\mathrm{Al}, \mathrm{B}, \mathrm{Ba}, \mathrm{Cd}, \mathrm{Cr}$ (total), $\mathrm{Cu}, \mathrm{Hg}, \mathrm{Mn}, \mathrm{Mo}, \mathrm{Ni}, \mathrm{Pb}, \mathrm{Sb}, \mathrm{Se}, \mathrm{Zn}, \mathrm{Br}, \mathrm{Cl}-\mathrm{CN}-\mathrm{F}^{-}, \mathrm{NH}_{4}{ }^{+}$, $\mathrm{NO}_{3}{ }^{-}, \mathrm{NO}_{2}{ }^{-}$and $\mathrm{SO}_{4}{ }^{2-}$. The calculations were carried out for all these parameters except $\mathrm{B}, \mathrm{Mn}, \mathrm{NH}_{4}{ }^{+}, \mathrm{NO}_{3}$-and $\mathrm{NO}_{2}$. It may be noted that it is to those "primary" groundwater quality criteria set at the POC that the requirement for criteria for monolithic waste to provide "the same level of environmental protection" as the criteria for granular waste refers.

In the Council Decision, leaching-based criteria were subsequently set for $\mathrm{As}, \mathrm{Ba}, \mathrm{Cd}, \mathrm{Cr}, \mathrm{Cu}, \mathrm{Hg}$. Mo, Ni, $\mathrm{Pb}, \mathrm{Sb}, \mathrm{Se}, \mathrm{Zn}$, chloride, fluoride, sulphate, DOC, phenol index, and TDS (as an alternative to chloride and sulphate) for waste to be accepted at landfills for inert waste. For landfills for nonhazardous waste receiving stable, non-reactive hazardous waste (from here on referred to as non-hazardous waste landfills) and landfills for hazardous waste, leaching based criteria were set for the same components as for inert waste landfills with the exception of the phenol index.

\section{Description of scenarios}

The landfill scenarios used in the TAC calculations are shown in Table 39. As can be seen, it is assumed that all three types of landfills will have a height of $20 \mathrm{~m}$, whereas the length and width of the inert waste landfill will be somewhat smaller ( $150 \mathrm{~m} \times 150 \mathrm{~m}$ ) than the length and width of landfills for non-hazardous and hazardous waste $(200 \mathrm{~m} \times 200 \mathrm{~m})$. No bottom liner is required for the inert waste landfills, whereas a composite liner with a thickness of the clay parts of $1 \mathrm{~m}$ and $5 \mathrm{~m}$, respectively, is required for the landfills for non-hazardous and hazardous waste. The 
general rate of infiltration of precipitation is assumed to be $300 \mathrm{~mm} /$ year. The anticipated operation period for all three types of landfills is 30 years.

A highly permeable top cover is assumed for the inert waste landfills, and a constant rate of infiltration (equal to the general rate of infiltration) of $300 \mathrm{~mm} /$ year is assumed for the inert waste landfills throughout the calculation period. Since no bottom liner is required, all of the infiltrating precipitation will percolate through the landfill and through the unsaturated zone (without any retention) into the aquifer below the landfill.

The hydraulic scenarios for the non-hazardous and hazardous waste landfills are more complicated as shown in Table 40. In this case a reduced rate of infiltration of $200 \mathrm{~mm} /$ year during the operation period (30 years) is assumed. At the end of the operation period the top is covered by an artificial liner which remains $100 \%$ effective for 30 years. The top cover then gradually deteriorates over the next 50 years until the rate of infiltration reaches and remains at $200 \mathrm{~mm} /$ year. The non-hazardous and hazardous waste landfills are assumed to be equipped with a composite bottom liner, i.e. an artificial liner on top of a clay liner. The artificial bottom liner is assumed to have an initial efficiency of $99 \%$ and gradually deteriorate to an efficiency of $0 \%$ over a period of 200 years, starting on day 1 of the operation period. The efficiency of the clay part of the bottom liner remains intact, corresponding to a permeability of $10^{-9} \mathrm{~m} / \mathrm{s}$ (or 31.5 $\mathrm{mm} /$ year at a gradient of $1 \mathrm{~m} / \mathrm{m}$ ). This means that after approximately 8 years the rate of release of leachate through the bottom of the landfill into the unsaturated zone is controlled by the clay liner (or by the top cover). It is assumed that the leachate which is not released through the bottom of the landfill is collected and managed (treatment and/or discharge). In fact, in the TAC calculations the collection and management of leachate is assumed to continue for as long as it is deemed necessary, i.e. quite likely beyond 110 years. 
Table 39: Description of landfill scenario conditions and assumptions used in the TAC calculations

\begin{tabular}{|c|c|c|c|c|}
\hline Parameter & Unit & $\begin{array}{l}\text { Inert waste } \\
\text { landfill }\end{array}$ & $\begin{array}{l}\text { Non-haz waste } \\
\text { landfill }\end{array}$ & $\begin{array}{l}\text { Hazardous waste } \\
\text { landfill }\end{array}$ \\
\hline Height of the landfill & $\mathrm{m}$ & 20 & 20 & 20 \\
\hline Length of the landfill & $\mathrm{m}$ & 150 & 200 & 200 \\
\hline Width of the landfill & $\mathrm{m}$ & 150 & 200 & 200 \\
\hline Surface area & $m^{2}$ & 22,500 & 40,000 & 40,000 \\
\hline Volume & $\mathrm{m}^{3}$ & 450,000 & 800,000 & 800,000 \\
\hline Porosity of the waste & - & 0.3 & 0.3 & 0.3 \\
\hline Dry bulk density of the waste & $t / m^{3}$ & 1.5 & 1.5 & 1.5 \\
\hline Dry weight of the waste & $\mathrm{t}$ & 675,000 & $1,200,000$ & $1,200,000$ \\
\hline Permeability of the waste & $\mathrm{m} / \mathrm{s}$ & $1 \times 10^{-5}$ & $1 \times 10^{-5}$ & $1 \times 10^{-5}$ \\
\hline Hydraulic conductivity of top cover & $\mathrm{mm} /$ year & $>300$ & variable: (0-200) & variable: $(0-200)$ \\
\hline Type of bottom liner & - & none & composite* & composite* \\
\hline Thickness of bottom liner (clay) & $\mathrm{m}$ & - & 1 & 5 \\
\hline Permeability of clay bottom liner & $\mathrm{m} / \mathrm{s}$ & - & $1 \times 10^{-9}$ & $1 \times 10^{-9}$ \\
\hline
\end{tabular}

Note: $\quad *$ Composite bottom liner (artificial liner + clay liner).

Table 40: Assumed water balances over time for landfills for non-hazardous and hazardous waste in the TAC calculations DHI \& ECN (2003) and Dijkstra (2004)

\begin{tabular}{|c|c|c|c|}
\hline $\begin{array}{l}\text { Period } \\
\text { Years }\end{array}$ & $\begin{array}{l}\begin{array}{l}\text { Infiltration through } \\
\text { top cover }\end{array} \\
\mathrm{mm} / \text { year }\end{array}$ & $\begin{array}{l}\text { Infiltration through } \\
\text { bottom liner }\end{array}$ & $\begin{array}{l}\text { Leachate to be collected } \\
\text { and treated and/or } \\
\text { discharged } \\
\mathrm{mm} / \text { year }\end{array}$ \\
\hline $0-30$ & 200 & Increasing from 2 to 31.5 & $\begin{array}{l}\text { Decreasing from } 198 \\
\text { to } 168.5\end{array}$ \\
\hline $30-60$ & 0 & 0 & 0 \\
\hline $60-80$ & $\begin{array}{l}\text { Gradually increasing from } 0 \\
\text { to } 200\end{array}$ & $\begin{array}{l}\text { Gradually increasing from } 0 \\
\text { to } 31.5\end{array}$ & 0 \\
\hline 80-110 & $\begin{array}{l}\text { Gradually increasing from } 0 \\
\text { to } 200\end{array}$ & 31.5 & $\begin{array}{l}\text { Gradually increasing from } 0 \\
\text { to } 168.5\end{array}$ \\
\hline $110-\infty$ & 200 & 31.5 & 168.5 \\
\hline Comment: & $\begin{array}{l}\text { No cover during operation, } \\
\text { placement of artificial liner } \\
\text { after closure }\end{array}$ & $\begin{array}{l}\text { Composite bottom liner. The } \\
\text { clay liner remains effective, } \\
\text { the artificial liner deteriorates } \\
\text { over } 200 \text { years }\end{array}$ & $\begin{array}{l}\text { Continuing leachate collec- } \\
\text { tion and management be- } \\
\text { yond } 110 \text { years assumed }\end{array}$ \\
\hline
\end{tabular}

Leaching by percolation is generally assessed as a function of the liquid to solid ratio (L/S), i.e. the accumulated amount of water (L) that has been in contact with a certain amount of waste, $S$ (in the landfill or in a test vessel). Table 41 shows the relationship between $\mathrm{L} / \mathrm{S}$ and time for the three landfill scenarios under consideration. 


\begin{tabular}{|c|c|c|}
\hline \multirow{2}{*}{$\begin{array}{l}\text { Time elapsed } \\
\text { (years) }\end{array}$} & \multicolumn{2}{|c|}{ Accumulated L/S (I/kg) } \\
\hline & Inert waste landfill & $\begin{array}{r}\text { Non-hazardous and hazardous } \\
\text { waste landfills }\end{array}$ \\
\hline 1 & 0.01 & 0.007 \\
\hline 10 & 0.10 & 0.07 \\
\hline 30 & 0.30 & 0.20 \\
\hline 60 & 0.60 & 0.20 \\
\hline 80 & 0.80 & 0.24 \\
\hline 100 & 1.00 & 0.31 \\
\hline
\end{tabular}

\section{The composition of the leachate as a function of $L / S$}

A rather crude and simplified description of the release of contaminants as a function of $\mathrm{L} / \mathrm{S}$ or time is used in the TAC calculations. Waste/waste interactions are neglected and the landfill is regarded as one large column or lysimeter, and it is assumed that the leaching of the contaminants under consideration can be described as an exponentially decreasing function of $\mathrm{L} / \mathrm{S}$ or time, originally based on a simple continuously stirred tank reactor (CSTR) model (see e.g. Hjelmar et al., 2001). The concentration C of a contaminant in the leachate (or eluate, from a laboratory leaching test) may then be estimated as follows:

$\mathrm{C}=\mathrm{C}_{0} \times \mathrm{e}^{-(\mathrm{L} / \mathrm{S}) \kappa}$ where

$\mathrm{C}_{0}$ is the initial peak concentration of the contaminant in the leachate (mg/l).

$\mathrm{L} / \mathrm{S}$ is the accumulated liquid to solid ratio corresponding to the concentration $\mathrm{C}(\mathrm{l} / \mathrm{kg})$.

$\kappa$ (kappa) is a kinetic constant describing the rate of decrease of the concentration as a function of $\mathrm{L} / \mathrm{S}$ for a given material and a given component $(\mathrm{kg} / \mathrm{l}) . \kappa$ may be estimated from laboratory leaching data and is for this purpose considered independent of the material/waste in question (this is not actually true as $\kappa$ may vary both with material and $L / S$, and the description of the source term may be improved by using material-specific $\kappa$ values over limited L/S ranges). 
By integrating the above expression, the amount of contaminant, E (in $\mathrm{mg} / \mathrm{kg}$ ), released over the period of time it takes for $\mathrm{L} / \mathrm{S}$ to increase from $0 \mathrm{l} / \mathrm{kg}$ to the value corresponding to $\mathrm{C}$, can be calculated:

$\mathrm{E}=\left(\mathrm{C}_{0} / \kappa\right)\left(1-\mathrm{e}^{-(\mathrm{L} / \mathrm{S})} \kappa\right)$

Only a limited number of determinations of $\kappa$ were available, and the values used for the inorganic contaminants in the TAC calculations were produced by Albers et al. (1996) based on column leaching tests performed on construction materials. Additional data on phenol and DOC were estimated by ECN (DHI and ECN, 2003). The values are listed in Table 42. A lower $\kappa$ corresponds to a slower decrease in leachate concentration, and this generally leads to a higher downstream peak groundwater concentration), all other things equal.

Figure 14 shows the influence of $\kappa$ on the rate of release of contaminants: For low values of $\kappa$ the changes in $\mathrm{C} / \mathrm{C}_{0}$ over a considerable $\mathrm{L} / \mathrm{S}$ (or time) range remains relatively small, whereas the changes are much more significant for larger values of $\kappa$. It should be noted the description of the release as exponentially decreasing function of $\kappa$ and $\mathrm{L} / \mathrm{S}$ or time is an oversimplification that helps in the setting of criteria, but does not fit all substances.

Table 42: List of the $\kappa$ values for inorganic components and phenol and DOC used in the TAC calculations

\begin{tabular}{|c|c|c|c|}
\hline Substance & $\begin{array}{l}\text { Average values and } 95 \% \\
\text { confidence intervals for } \mathrm{K}(\mathrm{kg} / \mathrm{l})\end{array}$ & $\begin{array}{l}\text { Number of } \\
\text { determinations }\end{array}$ & Data source \\
\hline As & $0.03 \pm 0.05$ & 44 & Aalbers et al. (1996) \\
\hline $\mathrm{Ba}$ & $0.15 \pm 0.04$ & 55 & Aalbers et al. (1996) \\
\hline $\mathrm{Cd}$ & $0.50 \pm 0.10$ & 37 & Aalbers et al. (1996) \\
\hline $\mathrm{Cr}$ & $0.18 \pm 0.03$ & 82 & Aalbers et al. (1996) \\
\hline $\mathrm{Cu}$ & $0.28 \pm 0.03$ & 90 & Aalbers et al. (1996) \\
\hline $\mathrm{Hg}$ & $0.05 \pm 0.03$ & 5 & Aalbers et al. (1996) \\
\hline Mo & $0.35 \pm 0.04$ & 76 & Aalbers et al. (1996) \\
\hline $\mathrm{Ni}$ & $0.29 \pm 0.05$ & 37 & Aalbers et al. (1996) \\
\hline $\mathrm{Pb}$ & $0.27 \pm 0.06$ & 52 & Aalbers et al. (1996) \\
\hline $\mathrm{Sb}$ & $0.11 \pm 0.07$ & 33 & Aalbers et al. (1996) \\
\hline $\mathrm{Se}$ & $0.38 \pm 0.18$ & 10 & Aalbers et al. (1996) \\
\hline $\mathrm{Zn}$ & $0.28 \pm 0.05$ & 41 & Aalbers et al. (1996) \\
\hline Chloride & $0.57 \pm 0.07$ & 45 & Aalbers et al. (1996) \\
\hline Fluoride & $0.22 \pm 0.14$ & 6 & Aalbers et al. (1996) \\
\hline Sulphate & $0.33 \pm 0.05$ & 49 & Aalbers et al. (1996) \\
\hline Phenol & 0.3 & & ECN (DHI \&ECN, 2003) \\
\hline $\mathrm{DOC}$ & 0.17 & & ECN (DHI \&ECN, 2003) \\
\hline
\end{tabular}




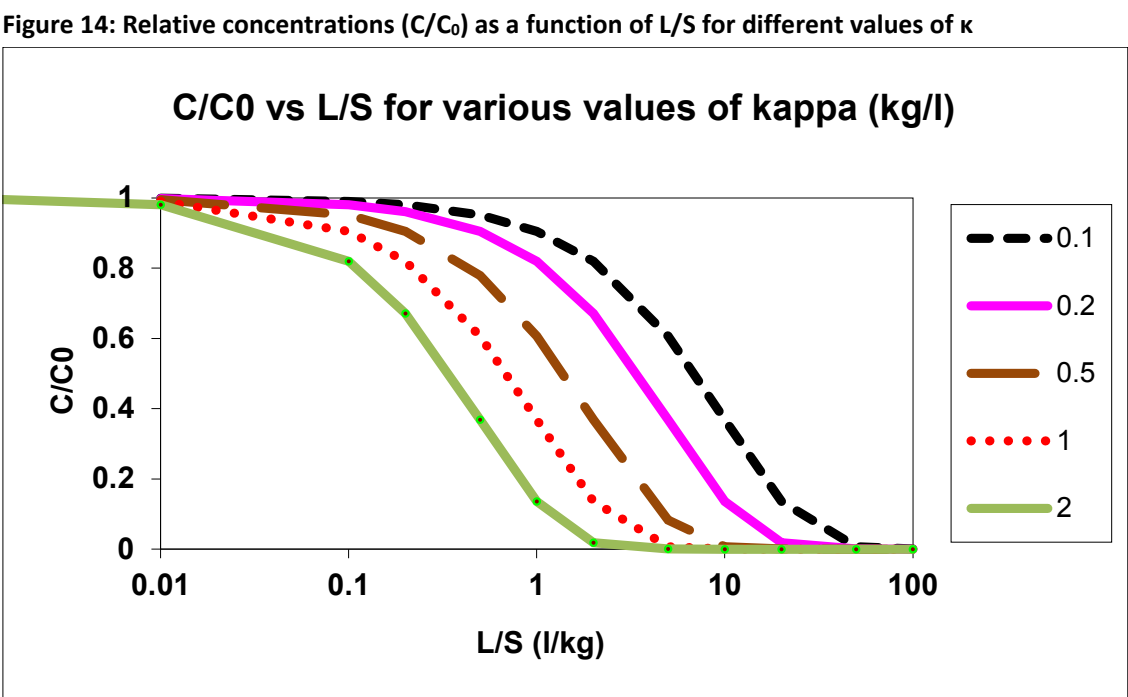

\section{Transport and groundwater quality parameters}

Table 43 shows the values of $K_{d}$ used to describe the contaminant/subsoil interaction in the transport modelling in the TAC calculations. The same $K_{d}$ values were used to describe the conditions in both the unsaturated and the saturated zones.

Table 43: Subsoil $K_{d}$ values (both for the unsaturated and saturated zones) and groundwater quality criteria used in the TAC calculations (DHI and ECN, 2003)

\begin{tabular}{lrr} 
Substance & $K_{d}(\mathbf{l} / \mathbf{k g})$ & GW quality criteria at POC ( $\mu \mathrm{g} / \mathbf{l})$ \\
$\mathrm{As}$ & & \\
$\mathrm{Ba}$ & 2 & 10 \\
$\mathrm{Cd}$ & 20 & 700 \\
$\mathrm{Cr}$ & 100 & 4 \\
$\mathrm{Cu}$ & 14 & 50 \\
$\mathrm{Hg}$ & 1 & 50 \\
$\mathrm{Mo}$ & 10 & 1 \\
$\mathrm{Ni}$ & 50 & 70 \\
$\mathrm{~Pb}$ & 50 & 20 \\
$\mathrm{Sb}$ & 5 & 10 \\
$\mathrm{Se}$ & 5 & 5 \\
Zn & 30 & 10 \\
Chloride & 0 & 100 \\
Fluoride & 2 & 250,000 \\
Sulphate & 0 & 1,500 \\
Phenol & 40 & 250,000 \\
DOC & 0 & 100 \\
\hline
\end{tabular}




\section{Transport modelling in the unsaturated and saturated zones}

The input to the transport model for the unsaturated zone in terms the flux of each contaminant as a function of time is calculated by combining the information on the flow of leachate out of the landfill with the information on the composition of the leachate as a function of $\mathrm{L} / \mathrm{S}$. For a given scenario, the relationship between $\mathrm{L} / \mathrm{S}$ and time is easily calculated (e.g. Hjelmar, 1990):

$\mathrm{t}=(\mathrm{L} / \mathrm{S}) \times \mathrm{d} \times \mathrm{H} / \mathrm{I}$

Where:

- $\mathrm{t}=$ the time since the landfill started producing leachate (years).

- $\mathrm{L}=$ the total volume of leachate produced at time $\mathrm{t}\left(\mathrm{m}^{3} /\right.$ year $)$.

- $\mathrm{S}=$ the total dry mass of waste deposited at the landfill (tonnes).

- $\mathrm{d}=$ the average dry bulk density of the deposited waste (tonnes $/ \mathrm{m}^{3}$ ).

- $\mathrm{H}=$ the average height of the landfill (m).

- $\mathrm{I}=$ the net rate of infiltration of precipitation (mm/year).

The TAC calculations were performed using CXTFIT/ECOSAT and HYDRUS 2D for the unsaturated zone and MODFLOW and MT3D for the saturated zone (DHI and ECN, 2003). More sophisticated models are available now (and have been used in later calculations).

Since the clay part of the bottom liners under the landfills constitutes the unsaturated zone, the parameter values for the unsaturated zone modelling can be seen in Table 1. Although no bottom liner is required for the inert waste landfills, the bottom of these was assumed to be placed 1 to $5 \mathrm{~m}$ above the groundwater level, and the unsaturated zone was assumed to consist of a sandy loam/loamy sand with little or no retention capacity. The parameters used in the numerical calculations for the transport through the unsaturated zone are shown in Table 44.

The parameter values used in the model calculations of the transport in the saturated zone are shown in Table 45 . Relatively high dispersivities were used deliberately in the model to ensure the occurrence of total vertical mixing in the aquifer, which was one of the pre-conditions (leading to equal concentrations of the transported substances at all depths of the 
aquifer at the POC). In this model the groundwater velocity of approximately $20 \mathrm{~m}$ /year was obtained by maintaining a fixed hydraulic head of $4.1 \mathrm{~m}$ at the downstream boundary of the model area.

\begin{tabular}{|c|c|c|c|c|}
\hline Parameter & Unit & Inert waste landfill & $\begin{array}{r}\text { Non-haz waste } \\
\text { landfill }\end{array}$ & Haz waste landfill \\
\hline $\begin{array}{l}\text { Thickness of unsaturated zone } \\
\text { (clay liner) }\end{array}$ & $\mathrm{m}$ & $1-5^{1)}$ & 1 & 5 \\
\hline $\begin{array}{l}\text { Hydraulic conductivity of unsatu- } \\
\text { rated zone }\end{array}$ & $\mathrm{m} / \mathrm{s}$ & $10^{-7}$ & $10^{-9}$ & $10^{-9}$ \\
\hline Dispersivity & $\mathrm{m}$ & 0 & 0 & 0 \\
\hline Porosity & - & 0.3 & 0.3 & 0.3 \\
\hline
\end{tabular}

Note: 1): not clay - sandy loam/loamy sand.

Table 45: Parameter values used in the TAC model calculations of transport in the saturated zone

$\begin{array}{lcr}\text { Parameter } & \text { Unit } & \text { Used by the TAC } \\ \text { Width of catchment } & \mathrm{m} & 500 \\ \text { Length of catchment } & \mathrm{m} & 600 \\ \text { Distance from water divide to beginning of landfill } & \mathrm{m} & 100 \\ \text { Distance to POC } & \mathrm{m} & 20 \text { and } 200 \\ \text { Net rate of infiltration } & \mathrm{mm} / \mathrm{year} & 300 \\ \text { Thickness of aquifer } & \mathrm{m} & \text { Approx. } 6 \\ \text { Upper boundary } & - & \mathrm{Closed} \\ \text { Fixed hydraulic head at downstream boundary } & \mathrm{m} & \text { Approx. } 4.1 \\ \text { Horizontal hydraulic conductivity Kx Ky } & \mathrm{m} / \mathrm{s} & 1.4 \times 10^{-4} \\ \text { Vertical hydraulic conductivity Kz } & \mathrm{m} / \mathrm{s} & 1.4 \times 10^{-4} \\ \text { Effective porosity } & - & 0.3 \\ \text { Longitudinal dispersivity } & \mathrm{m} & 20 \\ \text { Transversal dispersivity } & \mathrm{m} & 4 \\ \text { Vertical dispersivity } & \mathrm{m} & 2 \\ \text { Cell size } & \mathrm{m} & 10 \\ \text { Number of calculation layers } & - & 6\end{array}$

Source: DHI and ECN, 2003.

\section{Determination of attenuation factors and limit values}

Based on the numerical calculations and the observation of a peak value $\mathrm{C}_{\mathrm{Max}, \text { PoC }}$ for a given substance at the POC and the maximum (generally the initial) concentration of the substance at the bottom of the landfill, $\mathrm{C}_{0, \text { Land- }}$ fill, the attenuation factor, $\mathrm{f}_{\mathrm{a}}$, for the scenario and substance in question can be calculated: 
Once the attenuation factor (i.e. the ratio between the peak concentration at the POC and the peak concentration at the bottom of the landfill) has been determined for a given contaminant and a given landfill scenario, equation (4) can be used to determine the maximum allowable concentration, $\mathrm{C}_{0}$, Max, Landfill, at the base of the landfill corresponding to the groundwater quality criterion, $\mathrm{C}_{\mathrm{GWQ}}$, from Table 43 for the substance in question ("reverse modelling"). If the background concentration, $\mathrm{C}_{\mathrm{Backgr}}$, of the substance in the groundwater passing under the landfill is taken into account, $\mathrm{C}_{0}$, Landfill may be expressed as follows:

$\mathrm{C}_{0, \text { Landfill }}=\mathrm{C}_{0, \text { Max, Landfill }}-\mathrm{C}_{\mathrm{Backgr}}$

The maximum allowable concentration of the substance at the POC should also take the background concentration into account:

$\mathrm{C}_{\mathrm{Max}, \mathrm{POC}}=\mathrm{C}_{\mathrm{GWQ}}-\mathrm{C}_{\mathrm{Backgr}}$

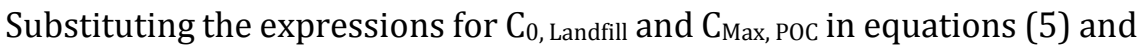
(6) into equation (4) gives the following:

$\mathrm{f}_{\mathrm{a}}=\left(\mathrm{C}_{\mathrm{GWQ}}\right.$ POC $\left.-\mathrm{C}_{\text {Backgr }}\right) /\left(\mathrm{C}_{0, \text { Max, Landfill }}-\mathrm{C}_{\text {Backgr }}\right) \Leftrightarrow$
$\mathrm{C}_{0, \text { Max, Landfill }}-\mathrm{C}_{\mathrm{Backgr}}=\left(1 / \mathrm{f}_{\mathrm{a}}\right)\left(\mathrm{C}_{\mathrm{GWQ}}\right.$ POC $\left.-\mathrm{C}_{\mathrm{Backgr}}\right) \Leftrightarrow$
$\mathrm{C}_{0, \text { Max, Landfill }}=\left(1 / \mathrm{f}_{\mathrm{a}}\right)\left(\mathrm{C}_{\mathrm{GWQ}}, \mathrm{POC}-\mathrm{C}_{\mathrm{Backgr}}\right)+\mathrm{C}_{\text {Backgr }} \Leftrightarrow$

In the TAC calculations, the background concentration of contaminants in the groundwater was not taken into account (i.e. $\mathrm{C}_{\mathrm{Backgr}}=0$ ), and equation (9) is simplified:

$\mathrm{C}_{0, \text { Max, Landfill }}=\left(1 / \mathrm{f}_{\mathrm{a}}\right) \times \mathrm{C}_{\mathrm{GWQ}}$, POC

The last step in the procedure is to calculate the actual limit value corresponding to the groundwater quality criterion, $\mathrm{C}_{\mathrm{GWQ}}$, POC, at the POC for a given substance for a percolation-related leaching test such as the column test CEN/TS 14405 or the corresponding compliance batch leaching test EN 12457 (part 1-4). To find the leaching limit value in terms of released amount $(\mathrm{mg} / \mathrm{kg})$ of a given component, the maximum allowable concentration, $\mathrm{C}_{0}$, Max, Landfill, found above is entered into equation (2) as $\mathrm{C}_{0}$. Using 
the appropriate value for $\kappa$ (see Table 42), the limit value $\mathrm{E}$ corresponding to a chosen $\mathrm{L} / \mathrm{S}$ value can be calculated:

$\mathrm{E}_{\mathrm{L} / \mathrm{S}}=\left(\mathrm{C}_{0, \mathrm{Max}, \text { Landfill }} / \kappa\right) \mathrm{x}(1-\exp (-(\mathrm{L} / \mathrm{S}) \kappa))$

Using equation (10), equation (11) can be changed to:

$E_{\mathrm{L} / \mathrm{S}}=\left(\left(1 / \mathrm{f}_{\mathrm{a}}\right) \times \mathrm{C}_{\mathrm{GWQ}}, \mathrm{POC} / \kappa\right) \times(1-\exp (-(\mathrm{L} / \mathrm{S}) \kappa))$

Most Member States have chosen the criteria set at $\mathrm{L} / \mathrm{S}=10 \mathrm{l} / \mathrm{kg}$ for regulatory purposes, but some Member States have chosen to test at $\mathrm{L} / \mathrm{S}=2$ 1/kg. The limit values in Council Decision 2003/33/EC has therefore been calculated both for $\mathrm{L} / \mathrm{S}=2 \mathrm{l} / \mathrm{kg}$ and $\mathrm{L} / \mathrm{S}=10 \mathrm{l} / \mathrm{kg}$ (and for $\mathrm{L} / \mathrm{S}=0.1 \mathrm{l} / \mathrm{kg}$ using equation (1)). In principle, the limit values at $\mathrm{L} / \mathrm{S}=2 \mathrm{l} / \mathrm{kg}$ or $\mathrm{L} / \mathrm{S}=$ $10 \mathrm{l} / \mathrm{kg}$ express the same degree of protection of the groundwater at the POC when they are calculated from equation (12) using the same values of $\mathrm{f}_{\mathrm{a}}, \mathrm{C}_{\mathrm{GWQ}}$, POC, and $\mathrm{K}$.

\section{The regulatory limit values}

Once the limit values were calculated using the scenario modelling, the results were subjected some consequence analyses using databases on waste leaching properties to assess the consequences in terms of percentages of waste passing or not passing criteria if the WAC were changed in one direction or the other compared to the risk-based calculated values. This supported the final political discussion in the TAC during which the values that are now in Council Decision 2003/33/EC were determined.

For each of the three classes of landfills, Table 46 shows the calculated leaching WAC and the actual leaching WAC for testing at $\mathrm{L} / \mathrm{S}=10 \mathrm{l} / \mathrm{kg}$ that resulted from the "political" discussion in the TAC and are appearing in Council Decision 2003/33/EC. Table 46 shows that for non-hazardous waste landfills accepting stable, non-reactive hazardous waste and particularly for hazardous waste landfills, the actual EU WAC may be up to 20 times higher than the values determined by the risk-related procedure described above. For inert waste landfills with no required top covers or bottom liners, the actual WAC are much closer to or even lower than the calculated WAC. 
Table 46: Comparison between modelled WAC and the actual WAC set by the TAC in terms of leaching limit values $(\mathrm{mg} / \mathrm{kg})$ at $\mathrm{L} / \mathrm{S}=10 \mathrm{I} / \mathrm{kg}$

\begin{tabular}{lrrrrrr} 
Parameter & \multicolumn{2}{c}{ Inert waste landfill } & Non-hazardous waste landfill & Hazardous waste landfill \\
& $\begin{array}{r}\text { Calculated } \\
\text { WAC }\end{array}$ & $\begin{array}{r}\text { Actual } \\
\text { WAC }\end{array}$ & $\begin{array}{r}\text { Calculated } \\
\text { WAC }\end{array}$ & $\begin{array}{r}\text { Actual } \\
\text { WAC }\end{array}$ & $\begin{array}{r}\text { Calculated } \\
\text { WAC }\end{array}$ & $\begin{array}{r}\text { Actual } \\
\text { WAC }\end{array}$ \\
& & & & & & \\
$\mathrm{As}$ & 0.27 & 0.5 & 1.8 & 2 & 3.3 & 25 \\
$\mathrm{Ba}$ & 8.2 & 20 & 50 & 100 & 63 & 300 \\
$\mathrm{Cd}$ & 0.079 & 0.04 & 0.57 & 1 & 1.5 & 5 \\
$\mathrm{Cr}$ & 3.7 & 0.5 & 27 & 10 & 78 & 70 \\
$\mathrm{Cu}$ & 0.86 & 2 & 5.9 & 50 & 14 & 100 \\
$\mathrm{Hg}$ & 0.016 & 0.01 & 0.095 & 0.2 & 0.1 & 2 \\
$\mathrm{Mo}$ & 0.94 & 0.5 & 6.4 & 10 & 15 & 30 \\
$\mathrm{Ni}$ & 0.87 & 0.4 & 6.3 & 10 & 18 & 40 \\
$\mathrm{~Pb}$ & 0.44 & 0.5 & 3.2 & 10 & 8.8 & 50 \\
$\mathrm{Sb}$ & 0.074 & 0.06 & 0.46 & 0.7 & 0.66 & 5 \\
$\mathrm{Se}$ & 0.093 & 0.1 & 0.62 & 0.5 & 1.2 & 7 \\
Zn & 2.9 & 4 & 21 & 50 & 55 & 200 \\
Chloride & 980 & 800 & 5,800 & 15,000 & 6,000 & 25,000 \\
Fluoride & 15 & 10 & 90 & 150 & 120 & 500 \\
Sulphate & 1,600 & 1,000 & 9,200 & 20,000 & 9,300 & 50,000 \\
DOC & 98 & 500 & 590 & 800 & 620 & 1,000 \\
Phenol index & 3.6 & 1 & - & - & - & - \\
\hline
\end{tabular}

\section{References}

Aalbers, Th.G., de Wilde, P.G.M., Rood, G.A., Vermij, P.H.M., Saft, R.J., van de Beek, A.I.M., Broekman, M.H., Masereeuw, P., Kamphuis, Ch., Dekker, P.M. \& Valejtijn, E.A. (1996). Environmental quality of primary and secondary construction materials in relation to re-use and protection of soil and surface water. RIVM-report no.: 771402007. National Institute of Public Health and the Environment, Bilthoven The Netherlands.

CEC (1998). Council Directive 98/83/EC of 3 November 1998 on the quality of water intended for human consumption. Official Journal of the European Communities, 05.12.1998, L330/32-54.

DHI and ECN (2003). Development of acceptance criteria for landfilling. Documentation of the modelling and scenario calculation carried out by DHI and ECN in support of the development of acceptance criteria for landfilling within the TAC Subcommittee on the Landfill Directive. Draft report for the Danish EPA and the Dutch Ministry of the Environment.

Dijkstra, J.J. (2004). Personal communication, ECN, The Netherlands.

Hjelmar, O. (1990). Leachate from land disposal of coal fly ash. Waste Management \& Research, 8, 429-449. http://dx.doi.org/10.1177/0734242X9000800170

Hjelmar, O. (2003). Environmental performance of waste materials. In: Dhir, R.K, Newlands, M.D. \& Halliday, J.E. (eds.): Recycling and Reuse of Waste Materials. Proceedings of the International Symposium held at University of Dundee, Scotland, UK on 9-11 September 2003, Thomas Thelford, London, pp. 653-668. 
Hjelmar, O., van der Sloot, H.A., Guyonnet, D., Rietra, R.P.J.J., Brun, A. \& Hall, D. (2001). Development of acceptance criteria for landfilling of waste: An approach based on impact modelling and scenario calculations. In: T.H. Christensen, R. Cossu and R. Stegmann (eds.): Sardinia 2001, Proceedings of the Eigth International Waste Management and Landfill Symposium, S. Margharita di Pula, Cagliari, CISA, Vol.III, pp. 712-721.

Hjelmar, O, Holm, J., Hansen, J.G., \& Dahlstrøm, K. (2005). Implementation of the EU waste acceptance criteria for landfilling in Denmark. In: Proceedings of 10th International Waste Management and Landfill Symposium, October 3-7, 2005, Cagliari, Sardinia.

VROM (2002). CD with documentation of the development of the leaching WAC in Council Decision 2003/33/EC. Prepared by the Dutch Ministry of Housing, Spatial Planning and the Environment (VROM). Distributed to the participating Member States.

WHO (1996). Guidelines for drinking-water quality, 2. ed. Vol. 2: Health criteria and other supporting information. World Health Organisation, Geneva. 
Nordic Council of Ministers

Ved Stranden 18

DK-1061 Copenhagen K

www.norden.org

\section{End-of-Waste Criteria for Construction \& Demolition Waste}

This report presents the situation within the Nordic countries with respect to production and recycling of construction and demolition waste, in particular crushed concrete, in the form of aggregates, and discusses the conditions and requirements relating to environmental impacts for a possible application of the End-of-Waste option in the Waste Framework Directive. If this option is applied, the material may become a product and it will no longer be regulated by waste legislation. Regulation of crushed concrete under product legislation presents a number of challenges, particularly with respect to environmental protection. The report presents and proposes a methodology for the setting of leaching and risk-based criteria to be fulfilled by crushed concrete (and other waste aggregates) in order to obtain End-of-Waste status. It is further recommended to set impactreducing conditions on the use of materials obtaining End-of-Waste criteria, and not to allow free use. It should be noted that the work described in this report was carried out and reviewed during the period from 2010 to 2012.

TemaNord 2016:524

ISBN 978-92-893-4561-3 (PRINT)

ISBN 978-92-893-4562-0 (PDF)

ISBN 978-92-893-4563-7 (EPUB)

ISSN 0908-6692

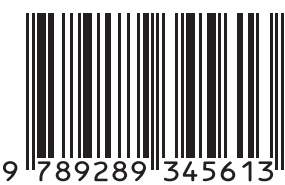

